\title{
ANÁLISE DESCRITIVA DO COMPORTAMENTO ESPECTRAL DE AMOSTRAS SUPERFICIAIS E SUBSUPERFICIAIS DE SOLOS DA REGIÃO DE RAFARD, SP
}

\author{
CARLOS FERNANDO QUARTAROLI \\ Engenheiro Agrônomo
}

Orientador: Prof. Dr. JOSÉ ALEXANDRE M. DEMATTÊ

\begin{abstract}
Dissertação apresentada à Escola Superior de Agricultura "Luiz de Queiroz", Universidade de São Paulo, para obtenção do título de Mestre em Agronomia, Área de Concentração: Solos e Nutrição de Plantas.
\end{abstract}

\author{
P I R A C I C A B A \\ Estado de São Paulo - Brasil \\ Julho -2001
}


ERRATA

\begin{tabular}{|c|c|c|c|}
\hline g. & item & linha & onde se lê \\
\hline 79 & 4.3 & 1 & intensidade mais baixa ... \\
\hline 79 & 4.3 & 18 & As curvas espectrais das camadas superficial ( $A$ e $A B)$ e a subsuperficial $(B t)$, \\
\hline 80 & 4.3 & 2 & a ligeira concavidade em todas as amostras. \\
\hline 80 & 4.3 & 7 a 9 & $\begin{array}{l}\text { As feiçōes de absorção soa pouco mais forte para os horizontes B texturais. } \\
\text { Concavidade larga na faixa de } 450 \mathrm{a} 600 \mathrm{~nm} \text { evidenciando a .... }\end{array}$ \\
\hline 80 & 4.3 & 10 & $\ldots$ entre 400 e $100 \mathrm{~nm} \ldots$ \\
\hline 80 & 4.3 & 11 e 12 & $\begin{array}{l}\text { Solo desenvolvidos sobre diabásio em terçco infeior de encosta, com expressiva } \\
\text { eluvação de argilas ... }\end{array}$ \\
\hline 80 & 4.3 & 15 a 19 & $\begin{array}{l}\text {... Perfil 12, amostras de superficie (Figura 22). } 0 \text { perfil desenvolvido sobre arenito } \\
\text { estratificado de granulometria, apresentando camadas mais resistentes e outras } \\
\text { camadas menos resistentes ao intemperismo. Uma camada mais resistente (R) pouco } \\
\text { afetada pleo inteperismo é encontrada entre o horizonte Bt e um estrato de rocha mais } \\
\text { alterado (camada }(r) \text {. Amostras dessa camada apresentaram a mas alta intensidade... }\end{array}$ \\
\hline 81 & 4.3 & 3 & ..., entretanto, este parece ... \\
\hline
\end{tabular}

\section{leiase}

uma diminuição da reflectância ...

As curvas espectrais dos horizontes $A, A B$ e $B t$

a ligeira concavidade em torno de $900 \mathrm{~nm}$ em todas as amostras,

As feições de absorção são um pouco mais fortes para amostras do horizonte $B$ textural. A concavidade larga na faixa de 450 a $600 \mathrm{~nm}$ evidencia a .... ... entre 400 e $1000 \mathrm{~nm}$...

$\dot{E}$ um solo desenvolvido sobre diabásio no terço inferior de encosta, com expressiva iluviação de argilas nos horizontes subsuperficiais ...

... Perfil 12 para amostras dos horizontes A e AB (Figura 22). Este perfil foi desenvolvido sobre arenito estratificado. Um estrato sedimentar mais resistente ao intemperismo forma a camada $R$, menos alterada que a camada subjacente $C r . A$ amostra da camada $R$ apresentou a maior intensidade...

...; entretanto, a matéria orgânica parece ...

amostras do horizonte $A$, principalmente $A 1$ mostraram um mascaramento de feiçōes amostras dos horizontes Ap e AB, principalmente de Ap, mostram um mascaramento em todo o espectro.

$81 \quad 4.3 \quad 13 \quad \ldots$ média $\left(220 \mathrm{~g} \mathrm{~kg}^{-1}\right)$, e alteraçōes na curva

$81 \quad 4.3 \quad 19 \quad$ A banda de absorção observada em $2265 / 2285 \mathrm{~nm}$ nas curvas ...

pare

$\begin{array}{llll}84 & 4.3 & 9,15 \text { e } 16 & \text { (Baumgardner et al., 1972) } \\ 85 & 4.3 & 1 & \text { (1970) e Boluda et al. (199 }\end{array}$

$854.3 \quad 1 \quad$ (1970) e Boluda et al. (1990). Além disso, os solos arenosos e os argilosos apresentarem

$4.3 \quad 15$ e $16 \quad$... ki mais baixos mineralogia caulinitica ou até oxidica, no caso de solos...

$4.3 \quad 19 \quad$... que na medida em que o ki...

Figura 30 eixoy Derivada primeira

$\begin{array}{lllll}88 & \text { Figura } 30 & \text { eixo y } & \text { Derivada primeira } & \text { Fator de reflectância } \\ 90 & 4.3 & 1 \text { e } 2 & \text { Em relação às camadas de alteração, amostras destas foram retiradas de um matacão } & \text { Amostra das camadas de alteração do diabásio foi retirada de um matacão com }\end{array}$ de diabásio com esfoliação concêntrica do perfil 5.

de feições em toda a extensão do espectro analisado.

... média $\left(220 \mathrm{~g} \mathrm{~kg}^{-1}\right)$, e apresenta alteraçōes na curva

A banda de absorção observada entre 2265 e $2285 \mathrm{~nm}$ nas curvas...

parte

... (Baumgardner et al., 1970)

(1972) e Boluda et al. (1993). Além disso, os solos arenosos e os argilosos apresentaram ...

... solos com Ki mais baixos têm mineralogia caulinítica ou até oxidica e são solos ..

... que à medida que $\mathrm{oki}$...

(Hunt et al., 1972)

$\begin{array}{llll}90 & 4.3 & 6 & \text { (Hunt et al., 1972) } \\ 90 & 4.3 & 13 & \text { A curva de rocha do perfil } 6 \text { ou } 7 \text { (cor } 0.3 \text { Y6.6/3.5) apresenta ... } \\ 90 & 4.3 & 22 & \text {... mais vennelhas, normalmente }\end{array}$

sinal de curvatura) em comprimentos de onda maiores,

$\begin{array}{ll}9 & \text { sob } \\ 2 & \text { a.. nestes minerais. }\end{array}$

esfoliação concêntrica (Figura 15b) encontrado no interior do solo, na mesma trincheira onde foi descrito o Perfil 5.

(Hunt et al..., 1971)

A curva de rocha do perfil 6 (cor 0,3 Y6,6/3,5) (Figura 16) apresenta ....

... mais vermelhas (ver cores das amostras no anexo A6, p. 112), nornalmente

sinal de curvatura) em valores de comprimento de onda maiores,

sobre

... nestes minerais. $\quad$... nestes minerais (Figura 30).

21 e Tais solos apresentam curvas espectrais homogêneas das amostras em profundidade As amostras de tais solos, coletadas em diferentes profundidades, apresentam curvas

1 a 5 que de fato ocorre na própria avaliação de campo. Aliás. Demattê (1995 e 1999) espectrais bastante semelhantes. A forna geral das curvas e as feiçães de absorção verificou que tais solos apresentam curvas hornogêneas das amostras dos horizontes são mantidas; apenas as intensidades de reflectância variam. Demattê (1995 e 1999) em relação aos aspectos descritivos. A tendência das curvas deste perfil é a mesma também verificou a semelhança das curvas espectrais de amostras de diferentes em profundidade reduzindo, entretanto, a intensidade de reflectância mas mantendo as horizontes de nitossolos quanto aos aspectos descritivos.

mesmas bandas de absorção.

$\begin{array}{llll}93 & 4.5 & 9 \text { e } 10 & \ldots \text {... Nitossolo (Figura 21) ... } \\ 94 & 4.5 & 9 & \ldots \text { na Figura 21, ratifica ... } \\ 95 & 5 & 2 & \ldots \text {... distintas, devido aos dados } \\ 95 & 5 & 3 & \text { intima } \\ 95 & 5 & 9 & \ldots \text { que as análises de Tipo. }\end{array}$

... Nitossolo (Figura 31) ...

... na Figura 31, ratifica ...

... distintas, segundo os dados

boa

.. ,óxidos de ferro hematita e goethita presente nos solos, pelos aspectos ...

$\begin{array}{ll}5 & \text { promovidas } \\ 14 & \text { uma infinidade }\end{array}$

coluna Hor. $\quad C B$

todos os valores da "ComposiçãoGranulométrica" devem ser multiplicados por 10 ,

substituirvalores da coluna "Grau de floculação" por 43, 38, 14, 21, 96

coluna Hor. A Bt1 Bt2 Bw1 Bw2

27 e $28 \quad$... amterial do horizonte; fragmentos rochosos extrememnte duros e extrememtne ...

29 folhelhos

substituir valor de argila total para Ap de 240 para 270 .

substituir yalores para $\mathrm{Cr}_{\text {nas colunas }} \mathrm{pH} \mathrm{H}_{2} \mathrm{O}$, pH KCl, $\mathrm{pH} \mathrm{CaCl}$ e Matéria orgânica: de 8,4 para 5,2; de 4,4 para 3,9; de 4,8 para 4,3; de 8 para 4

17 e $20 \quad$ Bt1 Bt2

coluna Hor. Bt1 Bt2

$21 \quad \mathrm{Bi}$

$40 \quad$ sonsist6encia

17, 19,23 Bi C Cr

colunaHor. $\mathrm{A} \mathrm{BiCCr}$

do que em análises descritivas por meio de comparações com curvas-padrão.

... óxidos de ferro, hematita e goethita pelos aspectos ...

expressas

diversas

c

A1p A2p Bt1 Bt2 Bw

... material do horizonte; fragmentos rochosos extremamente duros e extremamente ... siltitos

$B w 1$ Bw2

Bw1 Bw2

Bt

consistência

$\mathrm{C} \mathrm{Cr} C \mathrm{R}$

$\mathrm{ApC} C \mathrm{Cr}$

substituir valor de $\mathrm{pH} \mathrm{CaCl} 2$ para $\mathrm{Cr}$ de 4,6 para 4,8 e valor de "Grau de Floculação" para CR de 13 para 73.

substituir valores de Areia Grossa para Bte Bw de 0 para 10.

$\begin{array}{llll}134 & \text { A16 } & & \text { substituir valores } \\ 141 & 7 & 25 & \text { EPIPHÃNIO, J.C.N. }\end{array}$

$\begin{array}{llll}143 & 7 & 27 & (1,2-2,5 \mathrm{~nm})\end{array}$

EPIPHANIO, J. C.N.;LAMPARELLI, R.A.C.; BERTOLDO, M.A.; FORMAGGIO, A.R.

$(1,5-2,5 \mu \mathrm{m})$

$1980 \mathrm{a}$

1980

\section{Incluir no îtem 7 REFERẼN CIAS BIBLUOGRAFICAS}

MORAN, M.S.; IONOUE, Y.; BARNES, E.M. Opportunities and limitations for image-based remote sensing in precision crop management Remote Sensing Environment, v.61, p.319-346, 1997.

NANNI, M. R. Dados radiométricos obtidos em laboratório e no nivel orbital na caracterização e mapeamento de solos. Piracicaba, 2000. 366p. Tese (Doutorado) - Escola Superior de Agricultura Luiz de Queiroz,

Universidade de São Paulo.

SCHMERTMANN, U.; TAYLOR, R.M. Iron oxides. In: DIXON, J.B.; WEED, S.B. (Ed.). Minerals in soil environments. Madison: SSSA, 1977. p.145-180. 


\begin{tabular}{|c|c|c|c|c|}
\hline p. & îtem & linha & onde se lê & leiase \\
\hline 1 & 1 & 13 & Campinas em convênio com a EMBRAPA (1978), iniciou ... & Campinas, em convênio com a EMBRAPA, iniciou ... \\
\hline 2 & 1 & 3 & ... de determinação colocar em prática algumas das novas tecnologias disponiveis. & ... de algumas das novas tecnologias disponiveis serem colocadas em prática. \\
\hline $\begin{array}{l}3 e \\
4\end{array}$ & 1 & 22 e 23,1 & $\begin{array}{l}\text { É inversamente proporcional a importância do tema para os estudos pedológicos no } \\
\text { Brasil e o número de publicações. }\end{array}$ & (excluir) \\
\hline 4 & 1 & 14 e 15 & ... permitindo sua deteç̧ão e discriminação. & ... permitindo a discriminaçāo dos solos correspondentes. \\
\hline 6 & 2.2 & 20 e 21 & $\begin{array}{l}\text {... que deriva do comportamento espectral intrínseco devido às heterogêneas } \\
\text { combinaçōes ... }\end{array}$ & ... derivada das combinaçōes heterogêneas ... \\
\hline 7 & 2.2 & 3 e 4 & As observações da reflectância espectral da energia eletromagnética dos solos têm... & 0 fator de reflectãncia bidirecional dos solos tem .. \\
\hline 7 & 2.2 & 7 a 9 & $\begin{array}{l}\text {... pode ser considerado como uma superficie quase perfeitamente difusora, então } \\
\text { aquela razão è definida como "fator de reflectância bidirecional espectral" ... }\end{array}$ & ... deve ser uma superficie quase perfeitamente difusora ... \\
\hline 7 & 2.2 & 12 & .... particular. Em ... & ... particular ou numa faixa espectral com uma certa largura. Em ... \\
\hline 8 & 2.2 & 1 & ... das formas do espectro... & ... das formas e magnitudes do espectro ... \\
\hline 8 & 2.3 & 10 e 11 & A porção visivel das curvas de reflectãncia revelam ... & A porção do visivel das curvas de reflectância revela ... \\
\hline 17 & 2.4.1 & 17 & ..., a forma característica. & ..., a forma característica da curva espectral. \\
\hline 18 & 2.4.1 & 11 e 12 & ... e à água do solo, ou seja, a textura e a estrutura do solo. & ... e água do solo. \\
\hline 18 & 2.4.1 & 15 e 16 & ...(Stoner \& Baumgardner, 1980a, b; Coleman ... & ... (Stoner \& Baumgardner, 1980; Coleman ... \\
\hline 18 & 2.4.1 & 22 e 23 & $\begin{array}{l}\text { As curvas espectrais também podem ser avaliadas por amostras de terra coletadas de } \\
\text { um perfil do solo como realizado por Galvão et al. (1997). Tais autores identificaram }\end{array}$ & $\begin{array}{l}\text { Galvão et al. (1997) obtiveram as curvas espectrais de amostras de terra coletadas em } \\
\text { um perfil de solo a diferentes profundidades e verificaram }\end{array}$ \\
\hline 20 & 2.4.2 & 8,10 e 13 & banda 7: banda 3: banda 4: & (excluir) \\
\hline 20 & 2.4.2 & 11 & (banda 5: 1150-1750 nm) & $(1550-1750 \mathrm{~nm})$ \\
\hline 21 & 2.4 .2 & 18 & ... absorçāo mínima de transiçōes ... & ... absorção minimas atribuidas às transiç̧̄es... \\
\hline 22 & 2.4.2 & 7 & ... comente presentes em argilas mostram ... & ... comumente presentes em argilas, mostram ... \\
\hline 22 & 2.4 .2 & 9 & hidrófilas & hidroxilas \\
\hline 23 & 2.4.2 & 9 & .. (Hunt \& Salisbury, 1970; Hunt \& Salisbury, 1971). & ... (Hunt \& Salisbury, 1970) \\
\hline 33 & Figura 6 & legenda & P12 - CAMBISSOLO HÁPLICO Tb Distrófico típico & P12 - ALISSOLO HIPOCROMICO Argilúvico abrúptico \\
\hline 35 & 3.2 .2 & & ... foram georreferenciamento utilizando ... & ... foram georreferenciados utilizando ... \\
\hline 37 & 3.4 & 9 e 10 & A geometria é ilustrada na Figura $8 c$. & $\begin{array}{l}0 \text { sensor foi colocado na posição vertical a } 27 \mathrm{~cm} \text { de distância sobre a amostra. A } \\
\text { fonte de iluminação foi posicionada a } 61 \mathrm{~cm} \text { da amostra com um ângulo zenital de } 15^{\circ} \text {. }\end{array}$ \\
\hline 38 & 4.1 & 11 & A estrutura do $B$ (Anexo $A 1) \dot{e} . .$. & A estrutura do horizonte $B$ (Anexo A1) é ... \\
\hline 38 & 4.1 & 17 & teor de argila do $A$ é de ... & teor de argila do horizonte $A$ é de ... \\
\hline 39 & 4.1 & 6 e 7 & , com matiz mais amarelo que 5YR e tonalidade de 5.0 e intensidade menor que 4 & (excluir) \\
\hline 39 & 4.1 & 8 e 9 & $\begin{array}{l}\text {...distrófico porém, de argila constituída também de minerais } 2: 1 \text {, haja visto os } \\
\text { resultados elevados do Ki de } 3,43 \text {. }\end{array}$ & $\begin{array}{l}\text {... distrófico, porém possui minerais de argila } 2: 1 \text {, haja vista os resultados elevados } \\
\text { de } \mathrm{Ki} \text {, superiores a } 3 \text {. }\end{array}$ \\
\hline 39 & 4.1 & 18 a 23 & $\begin{array}{l}\text { A estrutura do horizonte de subsuperfície é em blocos, de grau moderado e a } \\
\text { espessura de } 20 \mathrm{~cm} \text {. } \\
\text { Cerca da metade do volume deste horizonte e pequena parte do horizonte } \\
\text { superficial está tomado por calhaus e cascalhos constituidos por seixos e fragmentos } \\
\text { rochosos (principalmente arenito) de tamanhos diversos concentrados de pedras } \\
\text { (Figura 12). Esta linha de pedras acaba álorando em situação de relevo mais baixa. }\end{array}$ & $\begin{array}{l}\text { O horizonte B, com } 20 \mathrm{~cm} \text { de espessura, apresentaestrutura em blocos } \\
\text { de grau moderado. Cerca da metade do volume deste horizonte está tomado por } \\
\text { calhaus e cascalhos, constituidos por seixos e fragmentos rochosos de tamanhos } \\
\text { diversos, predominando arenitos com forte cimentação por sílica. Estes materiais } \\
\text { encontram-se esparsos dentro do horizonte, sem uma orientação notável, e também } \\
\text { ocorrem no horizonte Ap, porém em quantidades menores. Em locais próximos e } \\
\text { mais baixos, estes fragmentos e seixos são encontrados na superficie do terreno. }\end{array}$ \\
\hline 43 & 4.1 & 19 & Tal valor indica uma ... & Este valor de Ki indica uma ... \\
\hline 44 & 4.1 & 3 & (Figura 17) sendo a rocha de origem representada por siltitos, $R 1$ e R2. (Anexo A7). & $\begin{array}{l}\text { (Figura 17). Este solo tem origem na alteração dos siltitos, encontrados nas camadas } \\
\text { R1 e R2 (Anexo A7). }\end{array}$ \\
\hline 44 & 4.1 & 19 a 21 & $\begin{array}{l}\text { Os dois primeiros horizontes são de textura arenosa (Anexo A9) com teores de argila } \\
\text { inferior a } 150 \mathrm{~g} \mathrm{~kg}^{-1} \text { transitando diretamente sobre } \circ \text { C. A estrutura é fraca e se } \\
\text { desfazendo em ... }\end{array}$ & $\begin{array}{l}0 \text { horizonte A, assentado diretamente sobre o horizonte C, é de textura arenosa } \\
\text { (Anexo A9) com teor de argila inferior a } 150 \mathrm{~g} \mathrm{~kg}^{-1} \text {. A estrutura é fraca e desfaz-se em } \\
\text {... }\end{array}$ \\
\hline 45 & 4.1 & 7 & ... pequeno revestimento de argila nos agregados definidos como cerosidade. & .... uma cerosidade fraca nos agregados. \\
\hline 45 & 4.1 & 14 & ... local plano, $2 \%$ declive (Figuras 6 e 7 ). & ... local plano, com declive inferior a $2 \%$ (Figuras 5 e 6 ). \\
\hline 45 & 4.1 & 15 & lenta & imperfeita \\
\hline 47 & 4.1 & 3 e 4 & $\begin{array}{l}\text {... ao } 14 \text { no que se refere a espessura e a posição que ocupa no relevo, meia encosta } \\
\text { (Figuras } 6 \text { e } 7 \text { ) e ao material de origem. }\end{array}$ & $\begin{array}{l}\text {... ao Perfil } 14 \text { quanto ao material de origem, à espessura e à posição de meia encosta } \\
\text { que ocupa no relevo (Figuras } 5 \text { e } 6 \text { ). }\end{array}$ \\
\hline 48 & 4.2 & 14 & ... algumas relaçōes são realizadas aos ... & ... algumas são feitas quanto aos... \\
\hline 49 & 4.2 & 3 & reto ligeiramente ... & reto a ligeiramente ... \\
\hline 49 & 4.2 & 8 e 9 & $\begin{array}{l}\text { em } 1400 \text { e } 1900 \mathrm{~nm} \text { devidas ds vibraçōes moleculares da água }+\mathrm{OH}^{-} \text {e água, } \\
\text { respectivamente .... }\end{array}$ & $\begin{array}{l}\text { em torno de } 1400 \text { e } 1900 \mathrm{~nm} \text {, a primeira atribuida às vibraçōes moleculares da água } \\
\text { e do } \mathrm{OH} \text {; a segunda atribuída às vibraçōes moleculares da água. }\end{array}$ \\
\hline $\begin{array}{l}50 \\
e\end{array}$ & 4.2 & 21 e 22,1 & $\begin{array}{l}\text { reflectância e são descritivamente diferentes as das camadas superficial e } \\
\text { subsuperficial. Observe que a curva do horizonte Ap não apresenta a concavidade }\end{array}$ & $\begin{array}{l}\text { reflectância. As curvas de amostras do horizonte A não apresentam a concavidade } \\
\text { centrada em torno de } 900 \mathrm{~nm} \text { e são de tipo diferente das demais amostras do perfil. }\end{array}$ \\
\hline 51 & & & centrada em $850 \mathrm{~nm}$, ao contrário das demais curvas . & \\
\hline 51 & 4.2 & 8 a 11 & $\begin{array}{l}\text { Apesar de que as curvas descritivas destes autores referem-se a horizontes de solos } \\
\text { e não transiçōes como no caso do horizonte C. }\end{array}$ & $\begin{array}{l}\text { Deve ser notado que as curvas descritivas destes autores referem-se aos horizontes } A \\
\text { e B de solos e não ao horizonte } C \text {. }\end{array}$ \\
\hline 51 & 4.2 & 17 & horizontes, tipo 1 de Formaggio ... & horizontes, correspondentes ao tipo 1 de Formaggio ... \\
\hline 51 & 4.2 & 21 & $\begin{array}{l}\text { o horizonte (Tabela 3) Ap e os horizontes C posteriores, passando do tipo } 2 \text { para } \circ 4 . \\
\text { A discriminação das curvas entre os horizontes pelos tipos concorda com ... }\end{array}$ & $\begin{array}{l}\text { o horizonte Ap e os demais horizontes, passando do tipo } 2 \text { para o } 4 \text { (Tabela 3). A } \\
\text { discriminação das curvas entre os horizontes, pelos tipos, concorda com ... }\end{array}$ \\
\hline 52 & 4.2 & 1 e 2 & ... (Figura 25) é semelhante ao Cambissolo anteriormente descrito ... & ... (Figura 25) são semelhantes ao Cambissolo anteriormente descrito (Perfil 11)... \\
\hline 52 & 4.2 & 9 & orgânica, apresenta-se sem a concavidade em 850 nm, formato ... & orgânica, não apresenta a concavidade em torno de $850 \mathrm{~nm}$ e tem formato ... \\
\hline 52 & 4.2 & 11 & 1400 e 1900 nm (Tipo 4) de Formaggio et al. (1996). & 1400 e 1900 nm, enquadrando-se no Tipo 4 de Formaggio et al. (1996). \\
\hline 59 & Figura 17 & gráfico & $\mathrm{CR}$ & $\mathrm{Cr}$ \\
\hline 60 & Figura 18 & legenda & ... horizontes do CAMBISSOLO ... & ... horizontes do Perfil 8 - CAMBISSOLO ... \\
\hline 63 & Figura 21 & gráfico & $\mathrm{Cg}$ & Crg \\
\hline 63 & Figura 21 & gráfico & Variação de angularidade devido à textura & (excluir) \\
\hline 64 & Figura 22 & legenda & CAMBISSOLO HAPLICO Tb Distrófico Tipico & ALISSOLO HIPOCRÔMICO Argilúvico abrúptico \\
\hline 65 & Figura 23 & gráfico & $A B$ & BA \\
\hline 70 & Tabela 3 & coluna Hor. & No Perfil 02 substituir Bi por Bt e CR por R; no perfil 11 substituir $\mathrm{Cg}$ por $\mathrm{Crg}$. & \\
\hline 71 & 4.3 & 3 e 4 & ...de terra, interage com todos as suas propriedades fisicas e químicas, sendo ... & de terra, interage com todos os seus constituintes, sendo ... \\
\hline 72 & 4.3 & 15 & verificada para amostras de rocha (Máximo em ... & è verificada para amostras da rocha (máximo em ... \\
\hline 75 & 4.3 & 9 & ... discussão na necessidade ... & ... discussão quanto à necessidade ... \\
\hline 75 & 4.3 & 22 & quando & quanto \\
\hline 76 & 4.3 & 17 & Perfil 17 & Perfil 07 \\
\hline 77 & 4.3 & 10 & ... para $15 / 10 \mathrm{gkg}^{-1}$ da camada superficial para as subsuperficiais. & $\ldots$ para 15 e $10 \mathrm{~g} \mathrm{~kg}^{-1}$ do horizonte superficial Ap para os horizontes $B$ e C. \\
\hline
\end{tabular}


Dados Internacionais de Catalogação na Publicação (CIP) DIVISĀO DE BIBLIOTECA E DOCUMENTAÇĀO - Campus "Luiz de Queiroz"/USP

\section{Quartaroli, Carlos Fernando}

Análise descritiva do comportamento espectral de amostras superficiais e subsuperficiais de solos da regiāo de Rafard, SP / Carlos Fernando Quartaroli. - Piracicaba, 2001.

$146 \mathrm{p}$.

Dissertação (mestrado) - - Escola Superior de Agricultura Luiz de Queiroz, 2001. Bibliografia.

1. Amostra de solo 2. Classificação do solo 3. Espectroscopia 4. Propriedade fisico química do solo 5. Mineralogia do solo I. Título

CDD 631.4 


\section{AGRADECIMENTOS}

Ao Prof. Dr. José Alexandre M. Demattê pela orientação deste trabalho.

À Escola Superior de Agricultura "Luiz de Queiroz" e o Departamento de Solos e Nutrição de Plantas pelo apoio e infra-estrutura oferecidos.

Aos colegas Peterson Fiorio, Rogério Campos e Aline Genú pelo auxílio na revisão desta dissertação.

Ao Técnico Agrícola Dorival Grizzoto pelo auxílio nos trabalhos de campo.

À Coordenação de Aperfeiçoamento de Pessoal de Nível Superior - CAPES, pela concessão da bolsa de estudo.

Aos funcionários do Departamento de Solos e Nutrição de Plantas da Escola Superior de Agricultura "Luiz de Queiroz"

A todos aqueles que participaram direta ou indiretamente deste trabalho. 


\section{Sumário}

RESUMO ..v

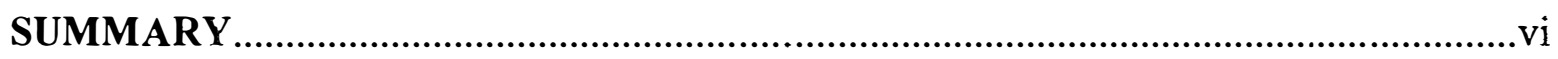

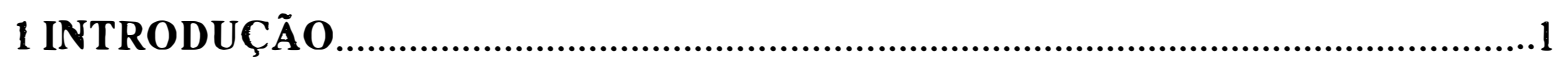

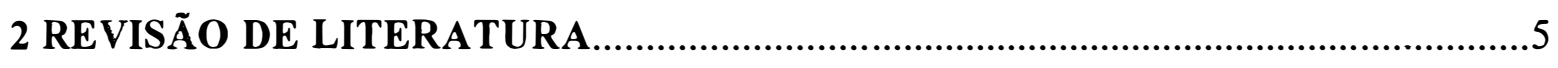

2.1 Breve histórico do sensoriamento remoto aplicado a solos................................5

2.2 Fundamentação para análise dos dados espectrais e solos................................6

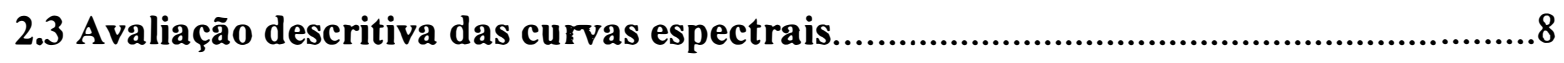

2.4 Relação entre dados espectrais e solos........................................................ 17

2.4.1 Atribu tos gerais dos solos e dados espectrais............................................17

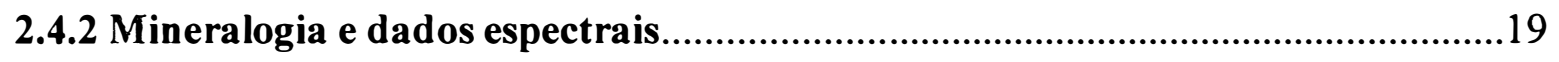

2.4.2 Comportamento espectral ao longo da paisagem .............................................19

2.4.3 Importância dos dados espectrais em laboratório..............................................26

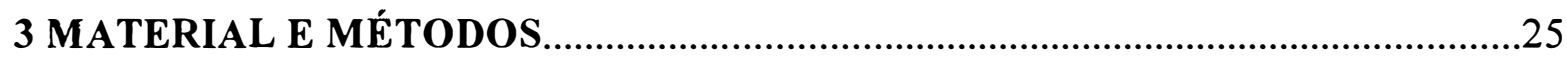

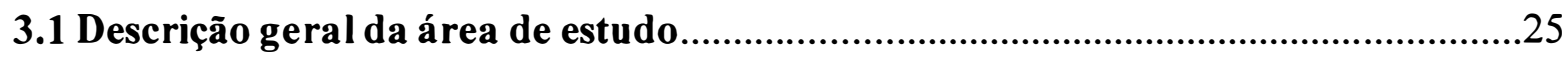

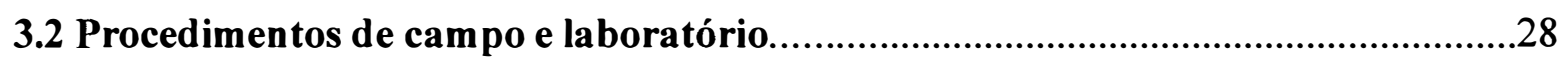

3.2.1 Demarcação dos perfis dos solos para análise ...............................................28

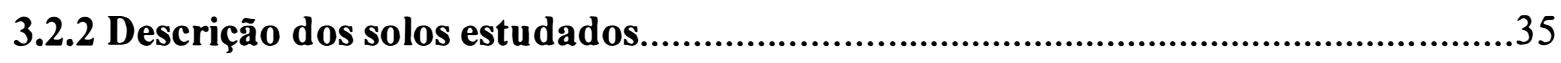

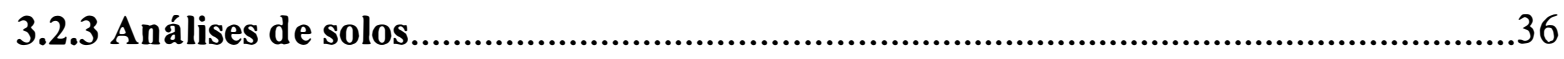

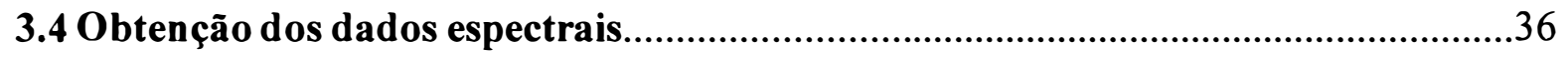




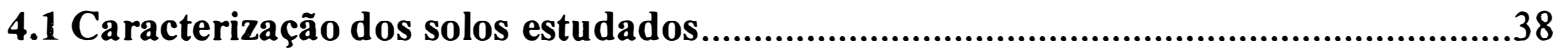

4.2 Caracterização descritiva do comportamen to espectral dos solos ........................48

4.3 Relação entre atributos dos solos e sua in fluência na energia

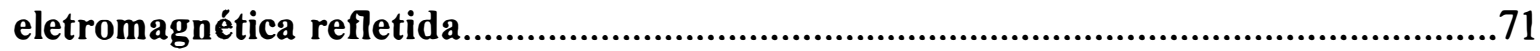

4.5 Comportamento espectral dos solos ao longo da paisagem e sua relação com a classificação

5 CONCLUSÕES .95

6 CONSIDERAÇÕES FINAIS. 97

7 ANEXOS 99

8 REFERÊNCIAS BIBLIOGRÁFICAS .137 


\title{
ANÁLISE DESCRITIVA DO COMPORTAMENTO ESPECTRAL DE AMOSTRAS SUPERFICIAIS E SUBSUPERFICIAIS DE SOLOS DA REGIÃO DE RAFARD, SP
}

\author{
Autor: CARLOS FERNANDO QUARTAROLI \\ Orientador: Prof. Dr. JOSÉ ALEXANDRE M. DEMATTÊ
}

\section{RESUMO}

O sensoriamento remoto apresenta importante potencial na avaliação do ambiente. Existe a necessidade de entender melhor as relações entre atributos dos solos e dados espectrais. O objetivo do presente trabalho, utilizando-se de um espectroradiômetro em laboratório (400 a $2500 \mathrm{~nm}$ ), foi de analisar descritivamente o comportamento espectral dos solos em amostras de perfis da região de Rafard, São Paulo. Procurou-se analisar as relações entre a energia eletromagnética refletida com os atributos físicos, químicos e mineralógicos dos solos, verificando as variações espectrais das amostras de terra ao longo de um perfil e sua relação com a classificação e discriminação dos solos. Foram descritos e amostrados 17 perfis de solos, de cujas amostras foram obtidas as curvas espectrais. Cada classe de solo apresentou características de classificação distintas, devido aos dados analíticos e morfológicos que, por sua vez, apresentaram íntima relação com os dados espectrais descritivos, discriminando as classes de solos. A análise descritiva observada na literatura pelos Tipos de curva, enquadraram os solos arenosos principalmente nos Tipos 2 e 4, e os solos com maior contribuição do diabásio no Tipo 1. Numa análise mais detalhada das curvas espectrais (Forma, feições e intensidades de absorção), porém, pode-se obter maiores informações sobre uma amostra de terra. Os solos arenosos refletiram mais, com curvas espectrais de aspecto ascendente, ao contrário do solos argilosos. A banda em 1900 
nm, discriminou solos com mineralogia 2:1 dos oxídicos e 1:1. Foi possível detectar a presença de caulinita, gibbsita, óxidos de ferro hematita e goethita presente nos solos, pelos aspectos descritivos das curvas, feições de absorção e intensidade de reflectância. Solos desenvolvidos de arenito apresentaram intensidades de reflectância mais elevadas do que os solos de diabásio. A avaliação dos dados espectrais de amostras dos horizontes superficiais e subsuperficiais permitiu discriminar a variabilidade analítica do perfil, auxiliando na discriminação dos solos e sua classificação. Existe relação entre os níveis de intemperismo dos solos e as informações espectrais. Os resultados indicam que as informações espectrais podem ser utilizadas como auxílio na caracterização, discriminação e classificação dos solos. 


\title{
DESCRIPTIVE ANALYSIS OF THE SPECTRAL BEHAVIOR OF SUPERFICIAL AND SUBSUPERFICIAL SOIL SAMPLES IN THE REGION OF RAFARD, SP
}

\author{
Author: CARLOS FERNANDO QUARTAROLI \\ Advisor: Prof. Dr. JOSÉ ALEXANDRE M. DEMATTÊ
}

\section{SUMMARY}

Remote sensing has a high potential for environmental evaluation. A necessity exists for a better understanding of the relations between the soil attributes and spectral data. The objective of this work, using a laboratory spectroradiomemter (400 to $2500 \mathrm{~nm}$ ), was to analyze the spectral behavior of soil samples from the region of Rafard, São Paulo. The relations between the reflected electromagnetic energy and the soil physical, chemical and mineralogical attributes were analyzed, verifying the spectral variations of soil samples in a profile with their classification and discrimination. 17 soil profiles were described and sampled, from which the spectral curves were obtained. Each soil class presented different classification characteristics, due to analytical and morphological data, that also presented a good relation with the descriptive spectral data, thus discriminating the different soil classes. The Types of Curves observed in the descriptive analysis taken from the literature, classified the sandy soils as Type 2 and 4 , and soils with a higher diabase contribution as Type 1. In a more detailed spectral curve analysis (shape, features and absorption intensity) more information can be obtained about a soil sample. The sandy soil reflected more, 
presenting a spectral curve with an ascendant aspect, opposite to clayey soils. The $1900 \mathrm{~nm}$ band, discriminated soil with 2:1 mineralogy from the oxidic and 1:1 soils. It was possible to detect the presence of kaolinite, gibbsite, hematite and goethite present in the soils by the descriptive aspects of the curves, absorption features and reflectance intensity. Soils developed from sandstone presented higher reflectance intensities that soil derived from diabase. The evaluation of the superficial and sub-superficial horizon samples permitted to discriminate the analytical variability of the profile, helping to discriminate the soils and their classification. A relation exists between the weathering stage and spectral data. The results indicate that the spectral data is a useful aid in the soil characterization, discrimination and classification. 


\section{INTRODUÇÃO}

Uma das bases fundamentais para o adequado planejamento agrícola é o conhecimento do solo. Neste aspecto, um assunto que vem recentemente sendo abordado, diz respeito a posição do pedólogo e o mapeamento de solos. Os pedólogos são os técnicos mais preparados para execução desse trabalho. Considerando a importância do conhecimento do solo para o ambiente e a produção, logo se vê sua necessidade. Por outro lado, como afirma Dalmolin (1999) "faltam pedólogos no Brasil”. Ou seja, um país com dimensões continentais e milhões de hectares de terras, capaz de produzir alimentos de forma racional e sustentável, não tem uma quantidade adequada de profissionais para realizarem esses mapeamentos. Aliás, os níveis de mapas de solos do Brasil, são na maioria de reconhecimento (Oliveira, 1988), incompatíveis com planejamentos agrícolas detalhados (Embrapa, 1989). O Instituto Agronômico de Campinas em convênio com a EMBRAPA (1978), iniciou um levantamento pedológico semi-detalhado do Estado de São Paulo na escala 1:100.000 (Oliveira, 1988). Apesar dos esforços dos profssionais dessas instituições, até hoje foi levantado aproximadamente $15 \%$ do Estado (Prado, 1997), demonstrando a necessidade de continuidade destes trabalhos. 
Essas questões nos levam a um primeiro questionamento: Por que faltam profissionais nesta área? Em recente discussão sobre o assunto, Demattê (2001) coloca que um dos fatores seria a necessidade de determinação colocar em prática algumas das novas tecnologias disponíveis. O que fazer então, para ampliar o conhecimento do meio físico como o solo? Estudar e colocar em prática tecnologias disponíveis, dentre as quais a análise do comportamento espectral dos solos por meio de sensores remotos. Muitos dos trabalhos desta área (Condit, 1970; Cipra, 1972; Stoner \& Baumgardner, 1980; Formaggio et al, 1996), vieram demonstrar a importância e a possibilidade de caracterizar os solos por sensores remotos ao nível terrestre (no campo ou laboratório). Por outro lado, e num passo seguinte, outros trabalhos demonstraram metodologias e/ou técnicas que efetivamente podem ser aplicadas no mapeamento (Andromikov et al., 1991; Demattê et al., 1999). A base de tais estudos está no fato de que cada solo, apresenta uma assinatura espectral, devido a cada atributo nele presente, atuar em determinado comprimento de onda (ou em todo o espectro eletromagnético) (Ben-Dor et al., 1999).

Epiphanio et al. (1992) colocam a necessidade de obtenção de um maior número de padrões espectrais de solos existentes no Brasil. Sem tais padrões, fica difícil colocar em prática as metodologias de radiometria hora existentes ou as futuras, aliás como verificado por Demattê et al. (2001). Tal importância aumenta na medida em que novos sensores estão sendo colocados em operação em aviões, como o AVIRIS, com 224 bandas (Baptista et al., 1998) e em satélites, como o Aires, com 105 bandas entre 400 e $2500 \mathrm{~nm}$, resolução espacial de $30 \mathrm{~m}$, e lançamento previsto para 2001 (CSIRO, 1997). Huete (1996) ratifica a importância do estudo do comportamento espectral dos solos ao 
nível laboratorial, na medida em que são as informações base para o entendimento e utilização destes dados em futuros trabalhos ao nível orbital.

Além disso, o adequado entendimento do sinal eletromagnético do solo implica também no conhecimento do comportamento espectral de outros alvos, como por exemplo a vegetação (Huete et. al., 1994). Aliás, Moran et al. (1997) também demonstraram a importância do sensoriamento remoto no levantamento do meio físico, como base para a agricultura de precisão.

Portanto, o que se nota, é que uma avançada e importante tecnologia como o sensoriamento remoto espectral, ainda não foi totalmente explorada na área de solos. Vários autores têm alertado para a necessidade de estudos espectrais com solos tropicais do Brasil (Epiphanio et al., 1992).

Dentro da espectralidade dos solos, verifica-se que no exterior, muito foi explorada por autores como Stoner \& Baumgardner (1981), que agruparam as curvas espectrais em diferentes tipos descritivos. Posteriormente, em trabalho pioneiro sobre solos do Brasil, Formaggio et al. (1996) determinaram tipos descritivos para os principais solos do Estado de São Paulo. Dada a importância básica dos estudos descritivos das curvas espectrais, verifica-se que pouco se tem discutido na literatura, principalmente em relação aos solos do Brasil. Não mais de uma dezena de artigos foram publicados sobre o tema no Brasil, restringindo-se a poucos autores (Formaggio, 1983; Epiphanio et al., 1987; Epiphanio \& Formaggio, 1988; Madeira Netto, 1996). O número de publicações é inversamente proporcional à importância do tema para os estudos pedológicos no Brasil, bem como aos avanços tecnológicos ocorrentes. É inversamente proporcional a importância do tema para os estudos pedológicos no Brasil 
e o número de publicações. Aliás, desde 1996, quando publicadas os tipos de curvas propostas por Formaggio et al., não se tem notícia de trabalhos que tenham efetivamente discutido sua viabilidade para os solos tropicais.

Neste sentido, o presente trabalho visou estudar o comportamento espectral de amostras de perfis de solos da região de Rafard, São Paulo, por meio de um espectroradiômetro em laboratório. Com isso, procurou-se atingir os seguintes objetivos: a) analisar as relações entre a energia eletromagnética refletida com os atributos físicos, químicos e mineralógicos dos solos; b) verificar as variações espectrais das amostras de terra ao longo de um perfil, relacionando-os com a classificação dos solos; c) avaliar as variações espectrais dos solos ao longo de uma topossequência; d) avaliar o potencial das análises espectrais descritivas na discriminação dos solos. Como hipótese de trabalho, têm-se que a energia eletromagnética interage com os componentes dos solos, como matéria orgânica e mineralogia, cujos teores, composições e estruturas distintas, promovem a formação de diferentes curvas de reflectância, permitindo sua detecção e discriminação. 


\section{REVISÃO DE LITERATURA}

\subsection{Breve histórico do sensoriamen to remoto aplicado a solos}

A fotografia aérea foi o primeiro produto do sensoriamento remoto a ser utilizado em levantamento de solos. O primeiro trabalho de levantamento de solos utilizando fotografias aéreas foi realizado por Bushnell et al., 1929, citado por França (1968) como meio para a avaliação de solos em mapeamentos. Buringh (1960) destacou as aplicações das fotografias aéreas em levantamentos, cabendo a Vink (1963) concluir que esses produtos têm maiores vantagens em mapas semi-detalhados. Posteriormente, França (1968) adaptou os conhecimentos fotointerpretativos sobre rede de drenagem relacionando com solos. A partir daí, uma série de trabalhos foram desenvolvidos como Carvalho (1972) e Demattê \& Demétrio (1996). Tais trabalhos fazem parte da base para o desenvolvimento do sensoriamento remoto fotointerpretativo.

Com o advento dos sensores remotos na década de 60 , trabalhos de espectroradiometria em laboratório e campo iniciaram-se como base para o estudo de solos, com o realizado por Bowers \& Hanks (1965). A partir daí, outros trabalhos de base foram desenvolvidos (Sherman \& Waite, 1985; Baumgardner et a.l., 1985), os 
quais partiram do princípio de que os atributos dos solos interferem diferenciadamente na reflectância. Surgia uma nova linha de pesquisa pedológica.

Dados os inúmeros trabalhos de base na área de radiometria, o sensoriamento remoto, tanto orbital como terrestre, passou a ser aplicado como técnica em levantamento de solos como o realizado por Biswas (1987) e Cruickshank \& Tomlinson (1988). Desde então, metodologias vêm sendo desenvolvidas com o propósito de colocar em prática os dados espectrais obtidos em laboratório, com realizado por Demattê et al. (2001). Entretanto, e conforme relatado por autores como Epiphanio et al. (1992), ainda faltam estudos básicos que deêm suporte aos trabalhos práticos, dificuldade aliás, encontrada por Demattê et al. (2001).

\subsection{Fundamentação para análise dos dados espectrais e solos}

A medida dos valores de reflectância de um corpo ou alvo ao longo do espectro eletromagnético é definida como o seu comportamento espectral. Como diferentes alvos podem apresentar respostas espectrais características, podemos, devido a esta propriedade, identificá-los na natureza (Sabins Jr., 1987). Dentre os diversos alvos passíveis de serem observados, o solo tem merecido especial atenção por muitos pesquisadores. Os trabalhos que surgiram ao longo do tempo sobre o comportamento espectral dos solos definem sua real importância como meio de identificação e de sua caracterização (Rosa, 1990).

A reflectância dos solos, portanto, é uma propriedade cumulativa que deriva do comportamento espectral intrínsico devido às heterogêneas combinações de matéria 
mineral, orgânica e fluida que compõem os solos minerais (Stoner \& Baumgardner, 1981).

As observações da reflectância espectral da energia eletromagnética dos solos têm sido quantificadas através da razão entre o fluxo radiante espectral refletido por uma superfície de solo e o fluxo radiante espectral refletido por um material de referência iluminado e visado sob as mesmas condições que a superficie de solo. $\mathrm{O}$ material de referência pode ser considerado como uma superficie quase perfeitamente difusora, então aquela razão é definida como "fator de reflectância bidirecional espectral" (Nicodemus et al., 1977).

Os sistemas de sensoriamento remoto detectam a intensidade da radiação eletromagnética emitida, refletida ou espalhada por um objeto em um comprimento de onda característico e particular. Em decorrência das condições de terreno, ocorrem variações na intensidade de radiação eletromagnética que são comumente manifestadas pela variação de brilho e luminância sobre as imagens (Sabins Jr., 1987).

Coleman et al. (1991) descreveram que nos estudos pedológicos, utilizando-se respostas espectrais é necessário, para tal, um melhor entendimento das relações existentes entre a reflectância espectral dos solos e os importantes parâmetros diferenciadores dos mesmos. Os autores observam ainda que, se bandas espectrais significativamente associadas com específicos atributos dos solos podem ser identificadas, então acurada estimativa das propriedades dos solos, através de dados de reflectância espectral, poderá ser realizada para facilitar o delineamento de unidades de solos. 
Assim, pelo exame das formas do espectro de reflectância pode-se extrair informações valiosas sobre características fisico-químicas dos solos. As variações espectrais, geralmente ligadas a fenômenos de absorção específica, podem ser quantificadas pelo uso de diferentes procedimentos. Estas possibilidades de identificação fazem da espectroscopia de reflexão um importante ferramenta para o estudo da composição dos solos, em laboratório, no campo, ou através de imagens de satélite (Madeira Netto, 1996).

\subsection{Avaliação descritiva das curvas espectrais}

Pesquisadores têm investigado descritivamente os padrões de reflectância de solos e minerais através de curvas espectrais obtidas em laboratório. A porção visível das curvas de reflectância revelam características espectrais semelhantes, contudo, na porção do infravermelho próximo e médio há grandes diferenças tanto na forma das curvas como na intensidade de reflectância (Stoner et al., 1980). Condit (1970) caracterizou as curvas de reflectância de solos conforme seus formatos característicos, identificando três tipos descritivos básicos de curvas para a faixa de comprimentos de onda entre 400 e $1000 \mathrm{~nm}$. Posteriormente, Stoner \& Baumgardner (1981) estudando amostras de cerca de 500 solos oriundos de 39 Estados americanos e algumas do Estado do Paraná, Brasil, na faixa de 520 a $2400 \mathrm{~nm}$ acrescentaram outros dois tipos de curvas às de Condit. A partir de então, as curvas espectrais dos solos americanos passaram a ser descritos conforme os tipos de curvas espectrais. 
As principais características dos 5 tipos básicos de curvas (Figura 1) e dos solos associados à elas foram descritos por Stoner \& Baumgardner (1981):

- Tipo 1 (dominado pela matéria orgânica): alto conteúdo de matéria orgânica, textura moderadamente fina; exibe uma reflectância baixa em toda a extensão do espectro analisado, com uma forma de curva côncava de 500 a $1300 \mathrm{~nm}$. Bandas de forte absorção de água estão presentes em 1450 e $1950 \mathrm{~nm}$. É associada freqüentemente a mineralogia de argila montmorilonítica.

- Tipo 2 (minimamente alterado): baixo teor de matéria orgânica, médio conteúdo de óxidos de ferro; alta reflectância em toda a extensão do espectro analisado e um forma de curva convexa característica de 500 a $1300 \mathrm{~nm}$. Em adição as bandas de forte absorção de água, bandas de fraca absorção de água podem estar presentes em 1200 e $1770 \mathrm{~nm}$. São associadas a solos bem drenados com textura e mineralogia variáveis.

- Tipo 3 (afetado por óxidos de ferro): banda de leve absorção de ferro férrico em $700 \mathrm{~nm}$ junto com uma mais forte em $900 \mathrm{~nm}$. Solos com conteúdo de óxidos de ferro de 10 a $40 \mathrm{~g} \mathrm{~kg}^{-1}$.

- Tipo 4 (afetado por matéria orgânica): tipicamente tem uma reflectância maior que as curvas do tipo 1 . Ela exibe uma forma côncava de 500 a $750 \mathrm{~nm}$ com uma forma convexa de 750 a $1300 \mathrm{~nm}$. É associada a solos com alto conteúdo orgânico e textura moderadamente grosseira . 
- Tipo 5 (dominado por óxidos de ferro): única curva em que a reflectância decresce com o aumento do comprimento de onda além de $750 \mathrm{~nm}$. Em alguns dos solos com este tipo de curva, a absorção no infravermelho médio é tão forte que a banda de absorção de água de 1450 a 1950 é quase obliterada. É associada a solos com alto conteúdo de óxidos de ferro (>40 g $\left.\mathrm{kg}^{-1}\right)$, textura fina e freqüentemente mineralogia de argila caulinítica. 


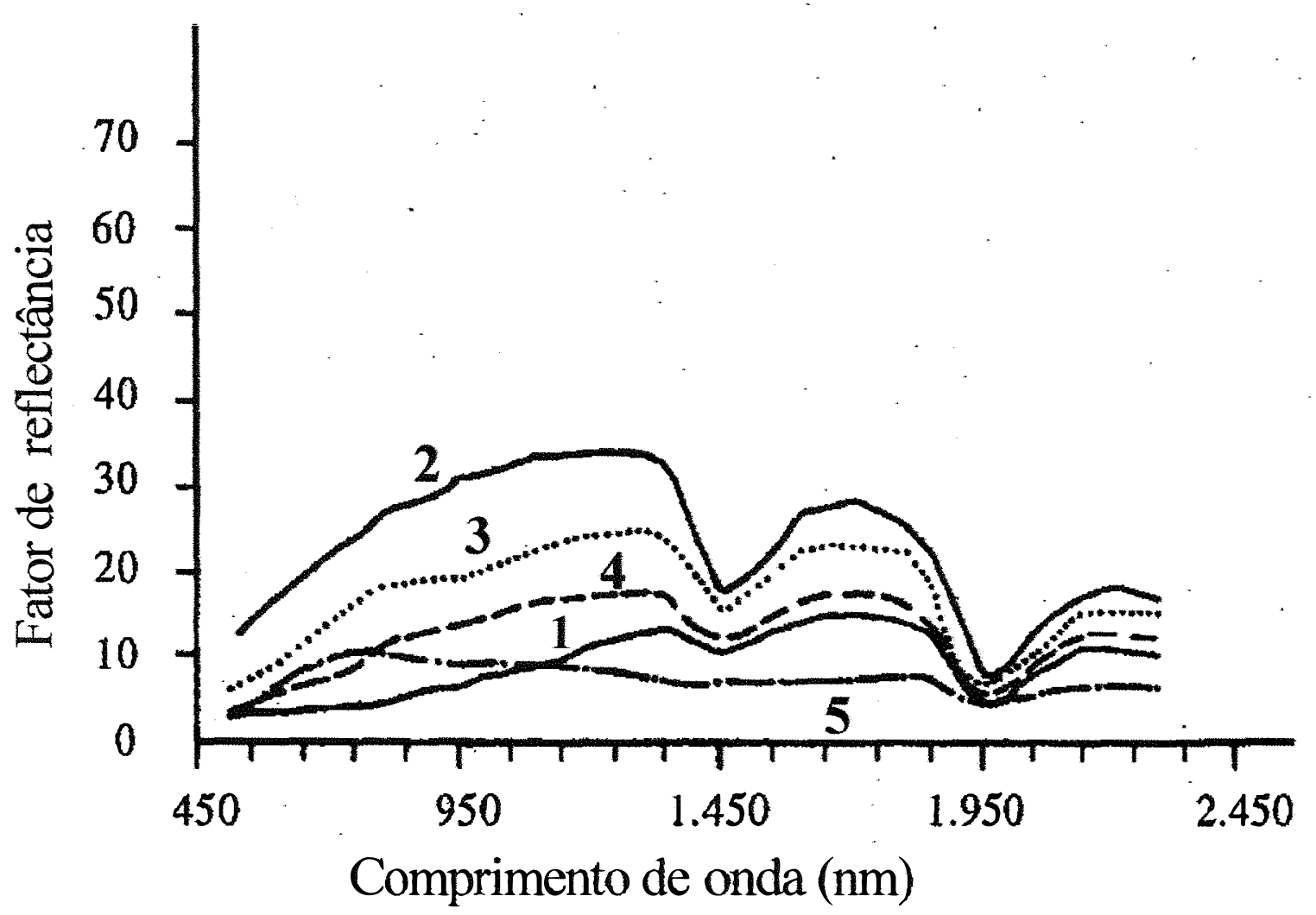

Figura 1. Curvas representativas de cinco padrões espectrais de solos minerais, segundo Stoner \& Baumgardner (1981), e o respectivo comportamento espectral: (a) dominado pela matéria orgânica (representado por um solo com elevado conteúdo de matéria orgânica ${ }^{(1)}$, textura moderadamente fina); (b) minimamente alterado (baixo teor de matéria orgânica, médio teor de óxido de ferro ${ }^{(2)}$ ); (c) Afetado por óxidos de ferro (baixo teor de matéria orgânica e médio teor de óxido de ferro; (d) afetado por matéria orgânica (elevado teor de matéria orgânica textura moderadamente grosseira) e (e) dominado por óxidos de ferro (elevado teor de óxidos de ferro, textura fina).1. Baixo teor de matéria orgânica: $0-20 \mathrm{~g} \mathrm{~kg}^{-1}$; alto teor: $>20 \mathrm{~g} \mathrm{~kg}^{-1} ; 2$. Baixo teor de óxido de ferro: $0-10 \mathrm{~g} \mathrm{~kg}^{-1}$; médio teor: $10-40 \mathrm{~g} \mathrm{~kg}^{-1}$; alto teor: $>40 \mathrm{~g} \mathrm{~kg}^{-1}$. 
Em relação aos solos tropicais, e principalmente os do Brasil, não se tinha padrões descritivos de curvas espectrais. Trabalho pioneiro foi o de Formaggio et al. (1996) que identificaram quatro tipos de curvas espectrais a partir de curvas obtidas de 109 amostras de 52 perfis e 13 classes de solos, representativas do Estado de São Paulo, Brasil. Os quatro padrões de curvas espectrais foram identificados segundo a forma das curvas e a intensidade de influência dos parâmetros: teor de óxido de ferro, teor de matéria orgânica e material de origem, dos quais, óxidos de ferro e matéria orgânica imprimiram maior influência espectral (Tabela 1, Figura 2). As características espectrais dos quatro grupos de solos foram reunidas na Tabela 2 por Valeriano et al. (1995).

Os tipos de curva de acordo com Formaggio et al. (1996) são a seguir caracterizados.

- Tipo 1: Típica dos Latossolos Roxo, as curvas espectrais apresentam-se influenciadas pelos elevados teores de óxidos de ferro totais $\left(>180 \mathrm{~g} \mathrm{~kg}^{-1}\right)$. Em geral são muito argilosos e com elevados teores de hematita (que lhes confere cores mais vermelhas que 3.5YR), de ilmenita e de magnetita, dado que são solos provenientes do intemperismo de rochas básicas. A Tabela 1 apresenta as análises dos solos representativos dos quatro padrões espectrais por eles determinados. As curvas apresentam albedo bem baixo, praticamente sem a presença de feições de absorção.

- Tipo 2: Tal tipo de curva em geral, são de solos, nos horizontes mais superficiais, predominância de texturas arenosas e médias, baixos teores de matéria orgânica e de óxidos de ferro e titânio. São muitas vezes provenientes de sedimentos arenosos e 
arenoargilosos oriundos do retrabalhamento de arenitos, podendo ser, ainda, ocasionalmente derivados de argilitos e siltitos. Como consequência, suas curvas espectrais são de albedos altos, com fatores de reflectância atingindo picos próximos a $60 \%$, localizados em comprimentos de onda próximos de $1800 \mathrm{~nm}$. As duas principais bandas da água (1450 e $1950 \mathrm{~nm})$ aparecem claramente, embora com largura e profundidades reduzidas. Como exemplo têm-se os Podzólicos VermelhoAmarelos.

- Tipo 3: Tal tipo pode ser representado pelo Latossolo Húmico e Hidromórficos. Os elevados teores de matéria orgânica imprimem as características mais marcantes nestas curvas. Na faixa entre 450 e $1450 \mathrm{~nm}$, para este solo, ocorre uma concavidade onde geralmente as curvas espectrais dos outros agrupamentos apresentam um típico comportamento convexo.

- Tipo 4: O quarto padrão de curvas é um tipo composto, ou seja, apresenta, no segmento de curva entre 450 e $1000 \mathrm{~nm}$, semelhanças com o primeiro padrão. No restante (1000 a $2500 \mathrm{~nm}$ ) apresenta semelhanças com a curva do segundo padrão. Como exemplo teríamos os Podzólicos Vermelho-Escuros. 
Tabela 1 - Características físicas e químicas de solos representativos dos quatro padrões espectrais mais significativos encontrados (Obs.: os padrões espectrais - Tipo 1, Tipo 2, Tipo 3 e Tipo 4 - citados a seguir estão representados na Figura 2). Fonte: Formaggio et al. (1996).

\begin{tabular}{|c|c|c|c|c|}
\hline \multirow[t]{2}{*}{ Características } & \multicolumn{4}{|c|}{ Padrões espectrais } \\
\hline & Tipo 1 & Tipo 2 & Tipo 3 & Tipo 4 \\
\hline Classe taxonômica & Latossolo Roxo & $\begin{array}{l}\text { Podzól. Verm- } \\
\text { Amarelo }\end{array}$ & Latossolo Húmico & Podzól. Verm.-Escuro \\
\hline Número do perfil & 1245 & 1387 & 1176 & 1388 \\
\hline$N^{\circ}$ da curva em Epi & & & & \\
\hline et al. (1992) & 1 & 73 & 61 & 78 \\
\hline Localização & $\begin{array}{l}\text { Quadrícula } \\
\text { Araras }\end{array}$ & Quadrícula Piracicaba & $\begin{array}{l}\text { Quadrícula } \\
\text { Campinas }\end{array}$ & Tietê (SP) \\
\hline Horiz. amostrado & A1 & Ap & A11 & $\mathrm{B} 2 \mathrm{t}$ \\
\hline Material de origem & $\begin{array}{l}\text { Decomposição } \\
\text { de diabásio }\end{array}$ & -- & $\begin{array}{l}\text { Sedimentos argiloso/ } \\
\text { Grupo Tubarão }\end{array}$ & $\begin{array}{l}\text { Folhelhos e Siltitos/Grupo } \\
\text { Passa Dois Formação Irati }\end{array}$ \\
\hline Areia grossa, $\mathrm{g} \mathrm{kg}^{-1}$ & 60 & 120 & 120 & 30 \\
\hline Areia fina, $\mathrm{g} \mathrm{kg}^{-1}$ & 230 & 720 & 330 & 290 \\
\hline Silte, $\mathrm{g} \mathrm{kg}^{-1}$ & 170 & 80 & 80 & 40 \\
\hline Argila, $\mathrm{g} \mathrm{kg}^{-1}$ & 540 & 80 & 470 & 640 \\
\hline $\mathrm{pH}$ & 7,3 & 5,3 & 4,8 & 5,2 \\
\hline $\mathrm{S}, \mathrm{mmol}_{\mathrm{c}} \mathrm{kg}^{-1}$ & 178 & 17 & 15 & 46 \\
\hline $\mathrm{T}, \mathrm{mmol}_{\mathrm{c}} \mathrm{kg}^{-1}$ & 185 & 39 & 157 & 71 \\
\hline Carbono, $\mathrm{g} \mathrm{kg}^{-1}$ & 30 & 6 & 36 & 6 \\
\hline Nitrogênio, $\mathrm{g} \mathrm{kg}^{-1}$ & 3,2 & -- & 3,2 & 0,8 \\
\hline $\mathrm{Fe}_{2} \mathrm{O}_{3}, \mathrm{~g} \mathrm{~kg}^{-1}$ & 213 & 8 & 53 & 59 \\
\hline $\mathrm{Al}_{2} \mathrm{O}_{3}, \mathrm{~g} \mathrm{~kg}^{-1}$ & 105 & 28 & 160 & 200 \\
\hline $\mathrm{SiO}_{2}, \mathrm{~g} \mathrm{~kg}^{-1}$ & 115 & 29 & 168 & 268 \\
\hline $\mathrm{TiO}_{2}, \mathrm{~g} \mathrm{~kg}^{-1}$ & 74 & 3 & 9 & 13 \\
\hline Cor Munsell & $2,5 \mathrm{YR}^{3} / 4$ & 7,5 YR $8 / 2$ & 5 YR $3 / 3$ & 2,5 YR 5/8 \\
\hline
\end{tabular}


Tabela 2 - Características espectrais dos grupos de solos (Valeriano et al., 1995)

\begin{tabular}{|c|c|c|c|c|}
\hline Tipo & 1 & 2 & 3 & 4 \\
\hline Albedo & $\begin{array}{l}\text { baixo, ao redor de } \\
15 \%\end{array}$ & $\begin{array}{l}\text { variável, entre } \\
20 \% \text { e } 70 \%\end{array}$ & $\begin{array}{l}\text { médio, entre } 30 \\
\% \text { e } 40 \%\end{array}$ & $\begin{array}{l}\text { médio, entre } 30 \% \text { e } \\
40 \%\end{array}$ \\
\hline Forma & $\begin{array}{l}\text { plano } \\
\text { horizontalmente }\end{array}$ & forma de arco & forma de arco & plano e inclinado \\
\hline Feições de absorção & $\begin{array}{l}\text { amplas em } 900 \text { e } \\
450 \mathrm{~nm} \text {, pouco } \\
\text { estreita em } 1400 \text {, } \\
1900 \text { e } 2200 \mathrm{~nm}\end{array}$ & $\begin{array}{l}\text { ampla em } 900 \text {, } \\
450 \text { e } 650 \mathrm{~nm} \text {, } \\
\text { bastante } \\
\text { estreita em } \\
1400, \quad 1900 \text { e } \\
2200 \mathrm{~nm}\end{array}$ & $\begin{array}{l}\text { feições } \\
\text { ausentes }\end{array}$ & $\begin{array}{l}\text { pouco ampla em } 900 \\
\text { nm, pouco estreita } \\
\text { em } 1400,1900 \text { e } \\
2200 \mathrm{~nm}\end{array}$ \\
\hline $\begin{array}{l}\text { Visível/Infravermelh } \\
\text { o próximo }\end{array}$ & $\begin{array}{l}\text { inflexão em } 650 \\
\mathrm{~nm} \text {, } \\
\text { cor vermelha }\end{array}$ & $\begin{array}{l}\text { nenhuma } \\
\text { inflexão, } \\
\text { apenas } \\
\text { inclinação, } \\
\text { cor amarela }\end{array}$ & $\begin{array}{l}\text { ampla, } \\
\text { cor cinza }\end{array}$ & $\begin{array}{l}\text { inflexão em } 650 \mathrm{~nm} \text {, } \\
\text { cor vermelha }\end{array}$ \\
\hline
\end{tabular}




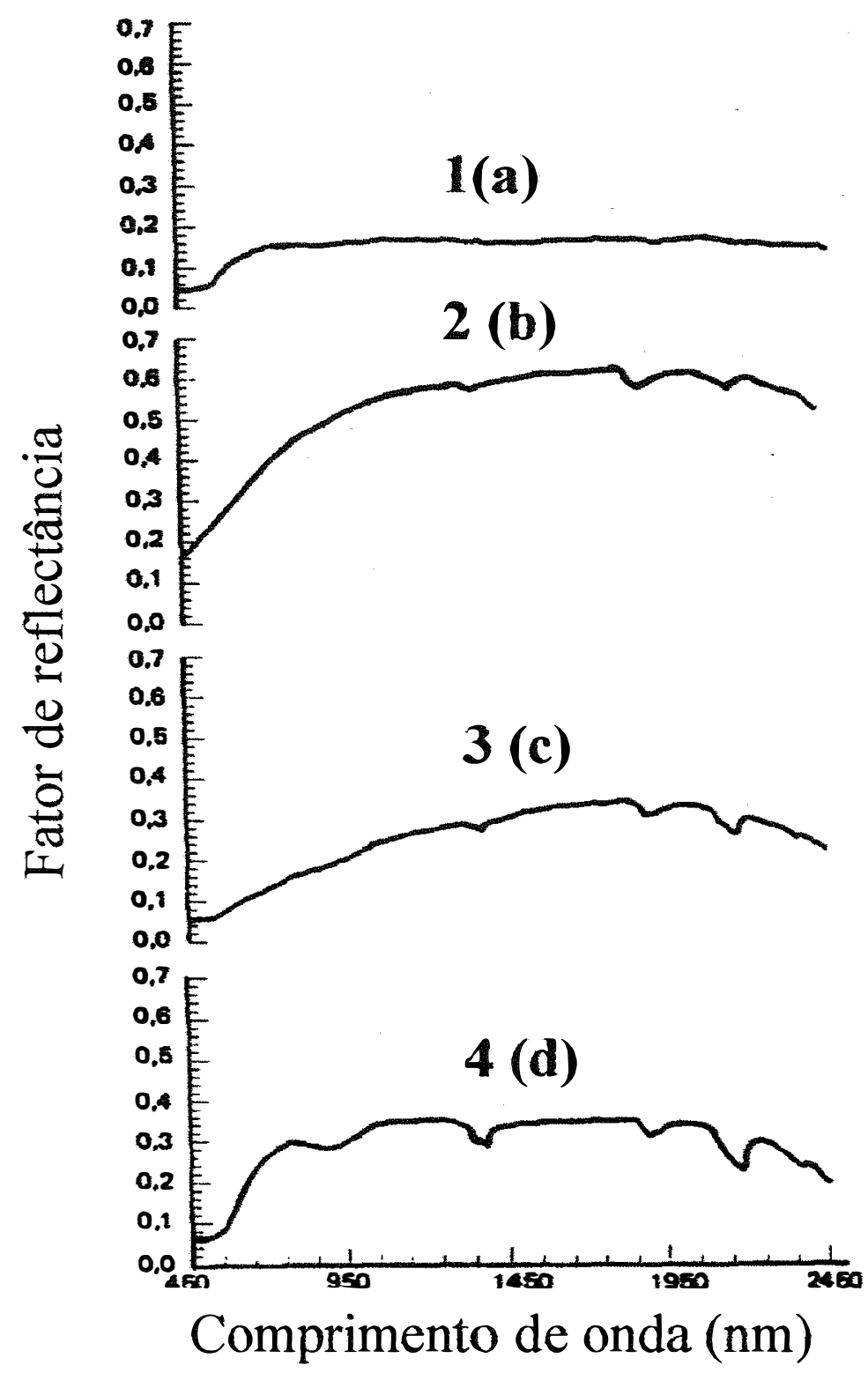

Figura 2. Curvas espectrais típica do horizonte Al de um Latossolo Roxo da região de Araras (SP) (a ou 1); curva espectral do horizonte "Ap" de um Podzólico Vermelho-Amarelo da região de Piracicaba (b ou 2); curva espectral do horizonte All de um Latossolo Húmico da região de Campinas (c ou 3); curva espectral do horizonte B2t de um Podzólico Vermelho-Escuro (PE) da região de Tietê (d ou 4). Fonte: Formaggio et al. (1996). 


\subsection{Relação en tre dados espectrais e solos}

\subsubsection{Atributos gerais dos solos e dados espectrais}

Num estudo em laboratório, Bowers \& Hanks (1965) observaram que as reflectâncias para a caulinita foram maiores que da bentonita. Atribuem o ocorrido às características de microestrutura e baixa densidade da bentonita.

Myers \& Allen (1968) afirmam que a reflexão difusa da luz, está associada com a cor dos solos, fato este comprovado anteriormente por outros autores, entre eles Obukov \& Orlov (1964).

A matéria orgânica tem um efeito importante nas características espectrais dos solos. Além dela promover um "tingimento" na coloração do solo, também está relacionada à capacidade de troca catiônica, estrutura e capacidade de retenção de água. Assim, muitos pesquisadores têm estudado os seus efeitos no caráter espectral dos solos, entre eles Baumgardner et al. (1970) e Al-Abbas et al. (1972).

Em relação à influência da umidade na reflectância, diversos trabalhos têm sido publicados. Entre eles, citam-se os de Bowers \& Hanks (1965), Montgomery (1974) e Beck et al. (1976), indicando que o aumento da umidade provoca a diminuição na reflectância dos solos, mantendo-se porém, a forma característica.

Mathews et al. (1973a) foram um dos primeiros a demonstrar a importância do material de origem sobre a reflectância do solo. As curvas de reflectância separaram solos desenvolvidos de calcários, folhelhos e arenitos, mostrando feições características em todos os comprimentos de onda. 
Costa (1979) concluiu que as mais importantes propriedades dos solos que são correlacionadas à sua cor, são a matéria orgânica, o conteúdo e o tipo de argilas e de ferro.

Formaggio (1983) estudou espectralmente solos desenvolvidos no Estado de São Paulo, determinando que existe uma boa correlação entre dados de campo e de laboratório. Donzeli (1984) obteve boa correlação entre parâmetro do solo, tais como, óxidos de ferro livre, matéria orgânica, cor e granulometria com a reflectância densitométrica relativa em amostras de Latossolos argilosos ou registros tonais nas imagens aerofotogramétricas.

De acordo com Epiphanio et al. (1992), a reflectância, assim como outras propriedades importantes do solo, é influenciada não somente pela composição química dos seus constituintes, como também pelo tamanho, arranjamento das partículas e à água do solo, ou seja, a textura e a estrutura do solo.

Os teores de umidade, matéria orgânica, óxidos de ferro e alumínio, os minerais de argila, a textura e as condições de superfície do terreno ou da amostra a ser analisada, têm proporcionado influências nas curvas espectrais de vários solos analisados (Stoner \& Baumgardner, 1980a, b; Coleman et al., 1991).

Henderson et al. (1992) estudando a faixa espectral de 400 a $2500 \mathrm{~nm}$, concluíram que pode-se prever teores de matéria orgânica em solos, porém, não a sua composição. A reflectância nas bandas do visível (425 a $695 \mathrm{~nm}$ ) foram as melhores correlacionadas com os teores de matéria orgânica de solos originados de mesmo material de origem.

As curvas espectrais também podem ser avaliadas por amostras de terra coletadas de um perfil do solo como realizado por Galvão et al. (1997). Tais autores identificaram 
diferenças entre os dados espectrais à diferentes profundidades, indicando sua importância como base do estudo espectral.

\subsubsection{Mineralogia e dados espectrais}

As investigações sobre as propriedades espectrais dos minerais bem como as leis fisicas que governam estas propriedades têm disponibilizado um grande conjunto de informações sobre a reflectância espectral de minerais e rochas. O comportamento espectral dos principais minerais constituintes de solos e materiais geológicos na faixa do visível (400 a $700 \mathrm{~nm})$, do infravermelho próximo (700 a $3000 \mathrm{~nm})$ e são apresentados a seguir.

Stoner \& Baumgardner (1981) concluíram que, por volta de 700 e $900 \mathrm{~nm}$, podem ser vistas as bandas de absorção devida a influência do $\mathrm{Fe}_{2} \mathrm{O}_{3}$. Em solos pobres em ferro, pode ser observada uma faixa mais estreita de absorção em 900 nm.

Mathews et al. (1973b) relatam que o tipo de mineral de argila influencia a forma e a intensidade da curva de reflectância em toda a faixa de 500 a $2600 \mathrm{~nm}$. Obtiveram diferentes curvas espectrais para caulinita, nontronita e ilita. Estes autores também observaram que a faixa espectral entre 500 e $1200 \mathrm{~nm}$ foi a que melhor diferenciou, o mesmo solo, com e sem óxidos de ferro, no horizonte B. A remoção de matéria orgânica, por sua vez, proporciona um aumento de reflectância entre 400 e 1300 nm. Por outro lado, Courault \& Girard (1988) verificaram que a remoção de matéria orgânica promoveu um aumento de reflectância de 400 a $2500 \mathrm{~nm}$. 
Para Kosmas et al. (1984), estudando Oxissóis do Brasil, a hematita absorve mais energia quando comparada com a goetita, devido a sua aparência mais escura. Esses óxidos também foram avaliados por Bedidi \& Cervelle (1996), chegando as mesmas conclusões.

As bandas do infravermelho médio, infravermelho próximo e vermelho são as mais importantes na explicação das variações ocorridas devidas a atributos dos solos como a matéria orgânica, umidade e teores de óxidos de ferro (Coleman \& Montgomery, 1987). O trabalho desses autores apresentou a banda do infravermelho médio (banda 7 : 2080-2350 nm) como a mais importante para detectar e determinar a variação nos teores de umidade dos solos estudados. A banda do vermelho (banda 3: 630-690 nm) e a do infravermelho próximo (banda 5: 1150-1750 $\mathrm{nm}$ ) foram as mais importantes para determinação do conteúdo e da variação dos teores de óxidos de ferro e a banda do infravermelho próximo (banda 4: 760-900 $\mathrm{nm}$ ) foi a melhor para determinar e explicar a variabilidade no conteúdo de matéria orgânica.

Metais de transição como $\mathrm{Fe}, \mathrm{Mn}, \mathrm{Cu}, \mathrm{Ni}, \mathrm{Co}, \mathrm{Cr}$, etc. dominam as feições espectrais na região de 400 a 1000 nm (Gupta, 1991). Processos eletrônicos nestes metais produzem bandas de absorção amplas (maior que $100 \mathrm{~nm}$ ) e são responsáveis pelo decaimento na reflectância de rochas em comprimentos de onda menores de 600 nm. (Vitorello \& Galvão, 1996).

Dos elementos de transição, o ferro é o mais importante a ser considerado na região espectral de 400 a $1000 \mathrm{~nm}$. A presença de $\mathrm{Fe}^{2+}$ em minerais produzem bandas ao redor de $600-700 \mathrm{~nm}, 900-1100 \mathrm{~nm}, 1800-1900 \mathrm{~nm}$ e $2200-2350 \mathrm{~nm}$. Em minerais ferromagnesianos, a feição mais proeminente ocorre ao redor de $900-1100 \mathrm{~nm}$. Em 
piroxênios ocorre feições variando de 900 a $1050 \mathrm{~nm}$ e de 1900 a $2350 \mathrm{~nm}$, com a posição do comprimento de onda variando de acordo com a composição do mineral. O mesmo ocorre com os anfibólios, que são bastante similares em composição aos piroxênios, exceto pela presença do radical $\mathrm{OH}$. $\mathrm{Na}$ série tremolita-ferroactinolita a transição eletrônica de $\mathrm{Fe}^{2+}$ ocorre de 800 a $1200 \mathrm{~nm}$ e a transferência de carga de $\mathrm{Fe}^{2+}$ - $\mathrm{Fe}^{3+}$ aparece de 600 a $700 \mathrm{~nm}$ (Vitorello \& Galvão, 1996).

$\mathrm{O}$ íon férrico $\left(\mathrm{Fe}^{3+}\right)$ está presente na goetita $(\mathrm{FeOOH})$ e na hematita $\left(\mathrm{Fe}_{2} \mathrm{O}_{3}\right)$, os dois minerais com ferro férrico mais freqüentemente encontrados em solos. Sherman \& Whaite (1985) definiu as posições das bandas de absorção atribuídas às transições eletrônicas na hematita e na goetita. Na hematita as bandas ocorrem em 885 nm, 650 nm, $530 \mathrm{~nm}$ e $445 \mathrm{~nm}$. Na goetita ocorrem em $917 \mathrm{~nm}, 650 \mathrm{~nm}, 480 \mathrm{~nm}$ e $435 \mathrm{~nm}$. Observa-se nas curvas espectrais que a hematita tem uma feição de absorção mais estreita em $885 \mathrm{~nm}$ do que a goetita em $917 \mathrm{~nm}$, entretanto, uma hematita de granulação grosseira, tem uma absorção mais larga, aproximando-se da posição e largura de uma goetita de granulação fina (Clark, 1999). Às transições eletrônicas localizadas em 530 nm para a hematita e $480 \mathrm{~nm}$ para a goetita são atribuídas as diferentes cores desses minerais. (Kosmas et al, 1984; Sherman \& Whaite, 1985).

Outros minerais têm feições de absorção mínima de transições eletrônicas relacionadas aos íons férrico e ferroso na faixa de 400 a $2500 \mathrm{~nm}$, como biotita, clorita, jarosita, lepidocrocita, maghemita e epidoto (Vitorello \& Galvão, 1996; Clark, 1999). Entre os demais metais de transição, o manganês $\left(\mathrm{Mn}^{2+}\right)$ exibe feições de absorção em $340 \mathrm{~nm}, 370 \mathrm{~nm}, 410 \mathrm{~nm}, 450 \mathrm{~nm}$ e $550 \mathrm{~nm}$. Outros importantes metais de transição 
incluem o $\mathrm{Cu}(800 \mathrm{~nm}), \mathrm{Ni}(400 \mathrm{~nm}, 740 \mathrm{~nm}, 1250 \mathrm{~nm})$ e o $\mathrm{Cr}(350 \mathrm{~nm}, 450 \mathrm{~nm}, 550$ nm) (Gupta, 1991).

A magnetita $\left(\mathrm{Fe}_{3} \mathrm{O}_{4}\right)$ e a ilmenita $\left(\mathrm{FeTiO}_{3}\right)$ são praticamente opacos, sem eventos ou feições espectrais entre 400 e $2400 \mathrm{~nm}$ (Hunt et al., 1971).

A região de 1000 a $3000 \mathrm{~nm}$ é caracterizada por feições espectrais de muitos constituintes aniônicos dos minerais, como hidroxilas, carbonatos e fosfatos. As hidroxilas, comente presentes em argilas mostram bandas de absorção perto de 2740 2770 nm e uma feição em 1440 nm, interferindo com feições similares observadas na molécula de água. Quando as hidrófilas aparecem combinadas com alumínio e magnésio, isto é, $\mathrm{Al}-\mathrm{OH}$ e $\mathrm{Mg}-\mathrm{OH}$, o que é muito comum em argilas e silicatos hidratados, diversas feições agudas são vistas na região de 2100 a 2400 nm (Gupta, 1991). Quando o $\mathrm{OH}$ é encontrado ligado à cátions metálicos em coordenação octaédrica há uma banda aguda ao redor de 2200 devido ao Al-OH, uma próxima a $2300 \mathrm{~nm}$ devido ao $\mathrm{Mg}-\mathrm{OH}$ e outra perto de 2290 causada pelo Fe-OH. (Hunt \& Salisbury, 1970; Hunt et al., 1971). Estas feições são esperadas estar presentes em espectros de materiais contendo argilas, micas e anfibólios (Vitorello \& Galvão, 1996).

$\mathrm{Na}$ região de 400 a $3000 \mathrm{~nm}$, as feições de absorção da água líquida são observadas em $1900 \mathrm{~nm}$ e $1400 \mathrm{~nm}$. Como a hidroxila também possui feição de absorção ao redor de $1400 \mathrm{~nm}$; minerais cujo espectro tem bandas em $1400 \mathrm{~nm}$, mas não em 1900 nm indica que apenas a hidroxila está presente (caulinita, por exemplo). Já minerais que cujo espectro tem uma banda de absorção em 1900 nm contém água (montmorilonita, haloisita, hectorita, por exemplo) (Clark, 1999). 
A gibbsita $\left(\mathrm{Al}_{2} \mathrm{O}_{3} 3 \mathrm{H}_{2} \mathrm{O}\right)$ tem feições espectrais atribuídas às vibrações dos grupos $\mathrm{OH}^{-}$. Na região de 400 a $2500 \mathrm{~nm}$ apresenta feições de absorção próximas de $1550 \mathrm{~nm}$ e $2300 \mathrm{~nm}$, além das feições de absorção da água próximo a 1400 e $1900 \mathrm{~nm}$. (Hunt et al., 1971).

Os carbonatos têm bandas de absorção vibracionais. As absorções observadas são devidas ao íon $\mathrm{CO}_{3}{ }^{2-}$. As duas bandas mais fortes ocorrem em $2500-2550 \mathrm{~nm}$ e em 2300-2350 nm. Três bandas mais fracas ocorrem em 2120-2160 nm, 1970-2000 nm e 1850-1870 nm (Clark, 1999). A posição das bandas em carbonatos variam com suas composições (Hunt \& Salisbury, 1970; Hunt \& Salisbury, 1971). As mais proeminentes feições ocorrem ao redor de $2335 \mathrm{~nm}$ para a calcita e $2320 \mathrm{~nm}$ para a dolomita (Vitorello \& Galvão, 1996).

A Figura 3 ilustra as curvas espectrais de alguns minerais.

\subsubsection{Comportamento espectral ao longo da paisagem}

O conhecimento do comportamento espectral dos minerais pode auxiliar na caracterização mineralógica de rochas, solos e produtos de alterações das rochas e ainda serem aplicados em estudos de alterações mineralógicas durante o intemperismo de rochas e a pedogênese.

Neste aspecto, poucos trabalhos abordaram as questões do intemperismo, variações das características dos solos ao longo da paisagem e sua relação com dados espectrais como realizado por Demattê et al. (1998b) e Demattê (1999). Autores como Demattê \& Garcia (1999), também fizeram este tipo de avaliação. Verificaram que 
ocorre uma relação entre os processos de formação dos solos e as curvas espectrais dos solos originados de basalto. A seqüência de intemperismo, tendo o Brunizém Avermelhado como solo menos intemperizado, seguido pela Terra Roxa Estruturada e finalmente pelo Latossolo Roxo, é acompanhada pelas características diferenciadoras das curvas espectrais e dados analíticos. 

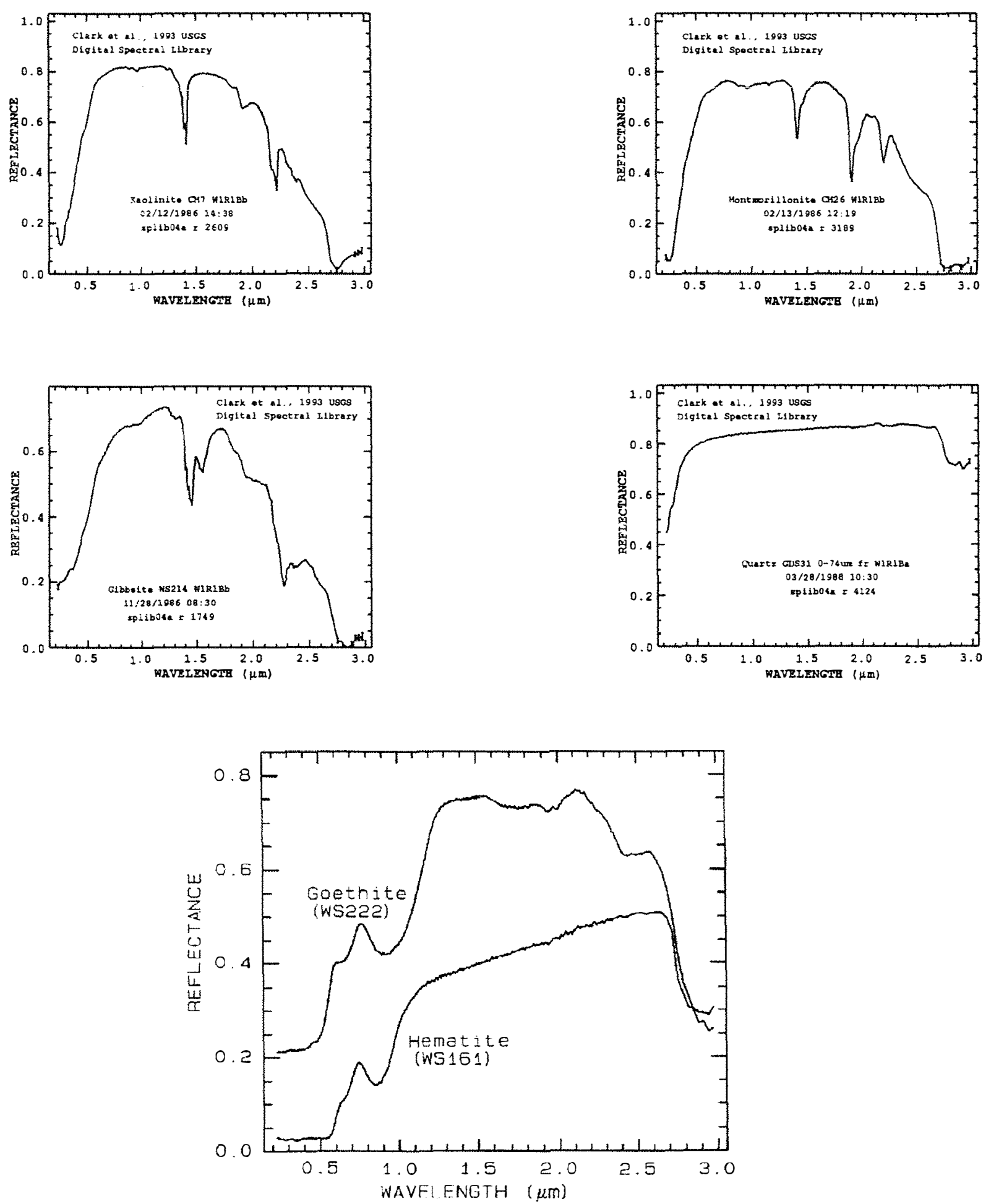

Figura 3. Curvas espectrais de alguns minerais. 


\subsubsection{Importância dos dados espectrais em laboratório}

A importância dos estudos em laboratório como base para o entendimento espectral ao nível orbital foi relatado por Huete (1996). Segundo o autor, a obtenção de dados espectrais em laboratório retrata de maneira mais fiel a informação, devido às menores interferências nas leituras espectrais. Ainda de acordo este autor, os dados de laboratório podem servir como base de estudo das informações espectrais obtidas ao nível orbital.

Portanto, os trabalhos ao nível de laboratório se justificam, dados os recentes avanços na tecnologia de sensores remotos. Estes avanços têm demonstrado sua importância ao obter a radiância com alta resolução espectral para cada posição (pixel), sendo um dos exemplos de maior evolução nesta área o Airbone Visible Infrared Imaging Spectroradiometer, designado de AVIRIS (Vane et al., 1993). Tal instrumento permite obter imagens espectrais de radiação refletida no intervalo 400 a $2500 \mathrm{~nm}$ com resolução de $10 \mathrm{~nm}$, e com 224 bandas. Com tal tecnologia, é de se esperar um maior detalhamento espectral indicando inclusive bandas de absorção importantes na identificação de rochas, minerais, vegetação e solos, desde que se considere que a resolução espacial seja suficiente para representar cada tipo de superfície para cada dado espectral.

Por outro lado, os dados espectrais em laboratório também são importantes como método auxiliar em levantamento de solos, conforme demonstrado por Demattê et al. (2001). 


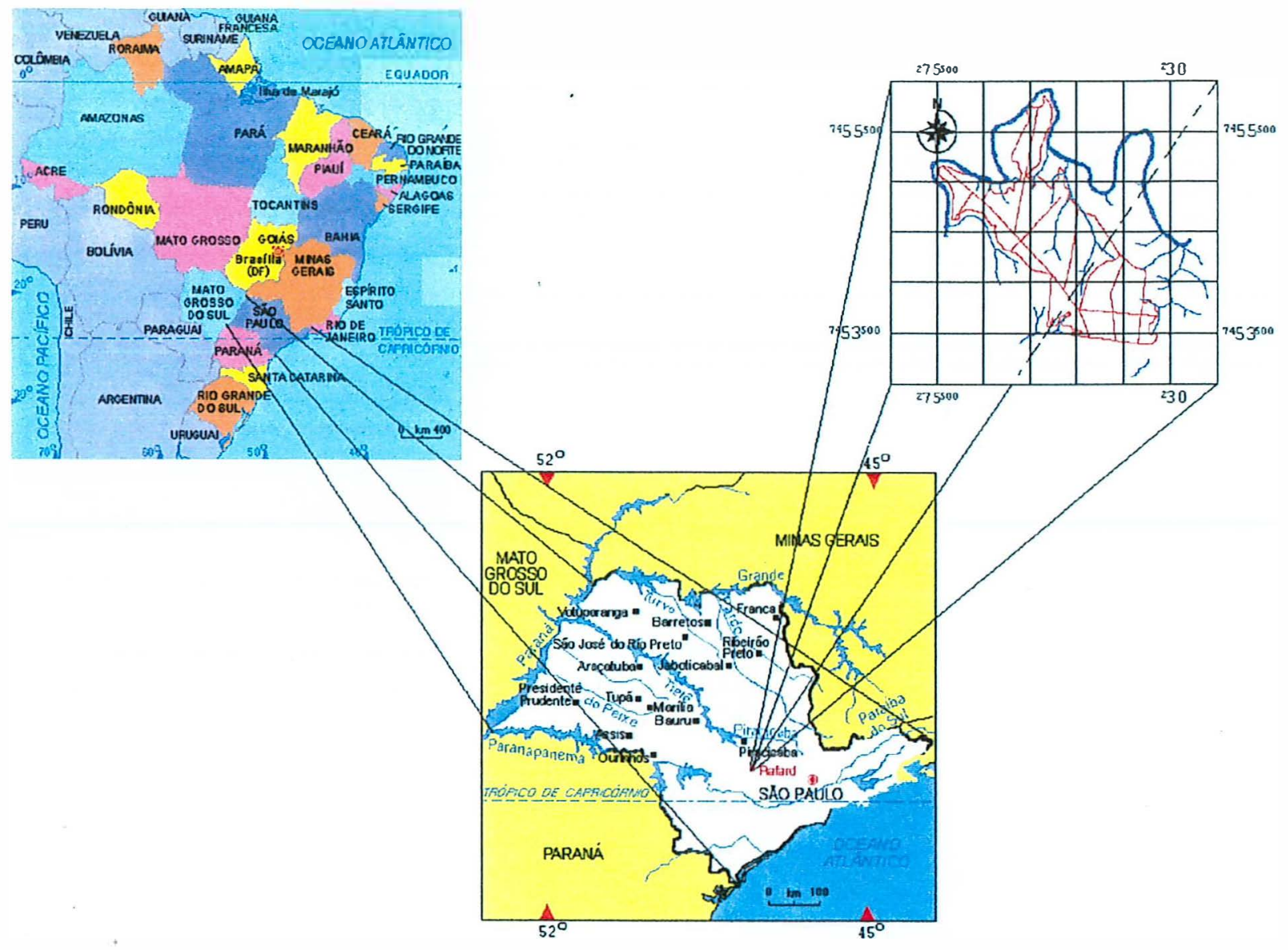

Figura 4. Localização da área de estudo. 


\section{MATERIAL E MÉTODOS}

\subsection{Descrição geral da área de estudo}

A área de estudo localiza-se no Município de Rafard, Estado de São Paulo, latitude $22^{\circ} 58^{\prime} 56^{\prime \prime} \mathrm{S}$ a $23^{\circ} 00^{\prime} 33^{\prime \prime} \mathrm{S}$ e longitude $47^{\circ} 39^{\prime} 32^{\prime \prime} \mathrm{W}$ a $47^{\circ} 37^{\prime} 55^{\prime \prime}$ (Figura 4) compreendendo área aproximada de 198 ha, margeada pelo rio Capivari, com altitudes variando entre 475 e $567 \mathrm{~m}$. O clima da região é do tipo Cwa (classificação de Köppen), caracterizado como clima mesotérmico de inverno seco com a temperatura média do mês mais frio inferior a $18^{\circ} \mathrm{C}$ e a do mês mais quente não ultrapassando $22^{\circ}$ C. O total das chuvas do mês mais seco não ultrapassa $30 \mathrm{~mm}$ (Comissão de Solos do Serviço Nacional de Pesquisas Agronômicas, 1960).

A região está localizada na unidade geotectônica denominada Bacia do Paraná e na unidade fisiográfica da Depressão Periférica Paulista. A geologia do local é dominada pela Formação Itararé. Esta formação, de idade entre o Carbonifero Superior e o Permiano Médio manifesta-se no Estado de São Paulo como uma complexa associação de variadas litofácies, quase todas detríticas, que se sucedem vertical e horizontalmente, de maneira mais ou menos rápida. As litologias predominantes são arenitos de granulação heterogênea, mineralogicamente imaturos, passando a arenitos 
feldspáticos e mesmo a arcósios, com características de origem diversas como fluviais, lacustres, praianos, deltaicos, eskers, eólicos, etc. A formação ainda apresenta diamictitos com clastos de diversas litologias, formas e dimensões, dispersos em matriz de natureza variada, de arenosa a síltico-argilosa e heterogênea em granulação; sedimentos rítmicos geralmente referidos como varvitos; conglomerados e arenitos conglomeráticos; siltitos, argilitos e folhelhos). Ocorrem ainda na região rochas eruptivas básicas (diabásios) constituindo corpos intrusivos na forma de diques e sills, de mesma composição dos basaltos toleíticos da Formação Serra Geral do JurássicoCretáceo (Almeida \& Melo, 1981).

De acordo com o "Levantamento Pedológico Semidetalhado do Estado de São Paulo" (Oliveira et al., 1982) , na área de estudo ocorrem as seguintes classes de solo:

- Podzólico Vermelho-Amarelo distrófico ou álico Tb, A moderado, textura argilosa caracterizados como solos não hidromórficos, normalmente com gradiente textural alto (entre 2 e 2,4) e transições claras e abruptas, seqüência de horizonte A, Bt e C ;

- Associação entre Podzólicos Vermelhos-Amarelos abruptos, A moderado, textura arenosa/média pouco profundos e Solos Litólicos eutróficos ou distróficos, A moderado, proeminente ou chernozêmico, textura média, substrato indiscriminado do Grupo Tubarão. 


\subsection{Procedimentos de campo e laboratório}

\subsubsection{Demarcação dos perfis dos solos pa ra análise}

Foram adotados alguns procedimentos para nortear a demarcação dos perfis para estudo. A escolha dos locais de amostragem baseou-se nas posições ocorrentes na topografia, observações no campo e que foram posteriormente visualizadas em mapas planialtimétricos e fotografias aéreas. A observação nas fotos e mapas, permitiu uma melhor visualização da paisagem (relevo) geral do local, auxiliando a demarcação dos pontos. Além disso, procurou-se marcar pontos em áreas de solos mais homogêneas e algumas de transição, ampliando a visão sobre a variabilidade espectral. A seguir são descritos estes procedimentos.

O mapa topográfico da área de estudo foi digitalizado manualmente (Figura 5), extraído das folhas SF-23-Y-A-IV-4-SO-F e SF-23-Y-C-I-2-NO-B na escala 1:10000 com eqüidistância de curvas de nível de $5 \mathrm{~m}$, publicado pela Secretaria de Economia e Planejamento do Governo do Estado de São Paulo e executado a partir de levantamento aerofotogramétrico executado pela TERRAFOTO S.A. em 1976. Foi utilizada mesa digitalizadora marca Digigraph, modelo Van Gogh e o software SPRING (Sistema de Informações Georreferenciadas) versão 3.5 a para o sistema operacional Windows.

Foi construído um modelo digital de elevação (MDE) utilizando-se os recursos do SPRING a partir das isolinhas de altitude digitalizadas e simplificadas pelo algoritmo de Douglas-Peucker com tolerância de isolinhas e de linhas de quebra de $2 \mathrm{~m}$. Entre os vários meios de construção disponíveis no SPRING, escolheu-se após inúmeros testes e 
consultas a literatura existente sobre o assunto, a modelagem através de rede triangular irregular (TIN) usando o critério de triangulação de Delaunay modificado, como as arestas dos triângulos não intersectando as isolinhas e a incorporação de linhas de quebra na triangulação, estas representadas pelos canais de drenagem e divisores de águas mais expressivos, o que possibilitou uma representação mais fiel do terreno, evitando suavizações de feições como vales e cristas (Figura 6).

Para a visualização do terreno em $3 \mathrm{D}$, foram construídas grades regulares a partir do TIN. Estas grades foram obtidas por interpolação linear em duas resoluções, sendo 10 $\mathrm{x} 10$ e $2 \times 2 \mathrm{~m}$.

Foram adquiridas cópias em papel de fotografias aéreas verticais pancromáticas nas escalas 1:25000 e 1:30000. Tais materiais foram obtidos em levantamento aerofotogramétrico executado pela Base - Aerofotogrametria e Projetos S.A. As fotografias na escala 1:25000 foram obtidas com filme preto e branco em junho de 1995; já na escala 1:30000 foi utilizado filme colorido em vôo realizado em 07 de julho de 2000. Foram necessárias três fotografias em cada escala, de tamanho $23 \times 23 \mathrm{~cm}$ para garantir a visão estereoscópica da área de estudo.

As fotografias aéreas foram visualizadas quanto à posição dos perfis na paisagem e serviram, juntamente com a carta topográfica como guia para a demarcação dos perfis a estudar. As fotografias centrais em cada escala foram transformadas em imagens digitais e salvas no formato TIFF (Tag Image File Format) e posteriormente convertidas para o formato GRIB (Gridded Binary) através do módulo IMPIMA do SPRING. A área digitalizada em cada fotografia correspondeu a um retângulo de dimensões pouco maiores que os limites da área de estudo. A fotografia na escala 1: 30000 resultou em 
imagem de 6.537 pixels por 4.758 pixels com resolução de 900 dpi e cores de 24 bits. A fotografia na escala 1:25000 resultou em uma imagem de 4.992 pixels por 2.762 pixels com resolução de 600 dpi e tons de cinza de 8 bits. Foram realizados testes com diferentes resoluções para escolher a mais adequada para cada caso, levando em consideração as imagens resultantes tanto no formato TIFF quanto no formato GRIB. Utilizou-se como critérios para a escolha: a definição e exatidão de cores, tons, feições e formas de objetos presentes nas imagens, mesmo em escalas maiores que a original; a memória necessária para armazenamento e a facilidade de manipulação da imagem dentro do SPRING.

Para o registro das fotografias aéreas foram obtidos pontos de controle. Foram coletadas as coordenadas de 50 pontos dentro da área de estudo e em suas vizinhanças com o auxilio do aparelho GPS Trimble TDC1, com correção diferencial dos dados captados. Os pontos foram localizados em locais de fácil identificação nas fotografias, como cruzamento de estradas, construções e pontes.

O registro é uma operação necessária para se fazer a integração de uma imagem à base de dados existente num SIG e compreende uma transformação geométrica que relaciona coordenadas de imagem (linha, coluna) com coordenadas de um sistema de referência, normalmente um sistema de coordenadas geográficas. Dos 50 pontos coletados foram selecionados 28 e 29 pontos para o registro das imagens resultantes das fotografias nas escalas 1:30000 e 1: 25000 respectivamente, utilizando-se como critério de seleção os pontos, mais facilmente identificáveis nas imagens, a distribuição uniforme dos pontos e os pontos de menores erros entre os valores fornecidos pelo GPS e os calculados após a transformação das coordenadas originais das imagens em 
coordenadas geográficas através de um polinômio de terceiro grau ajustado pelo método dos mínimos quadrados. A Figura 7 ilustra a fotografia aérea. 


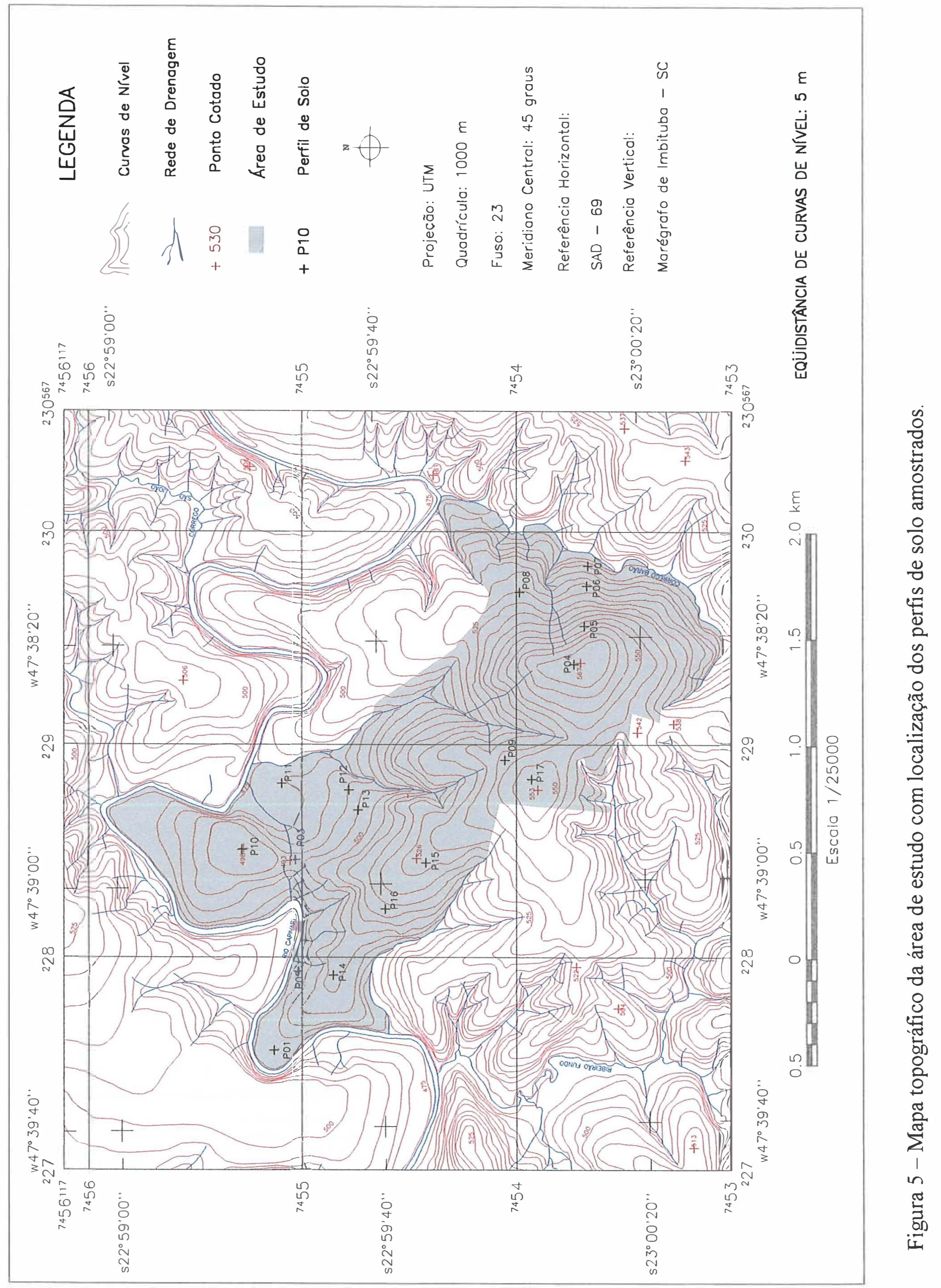




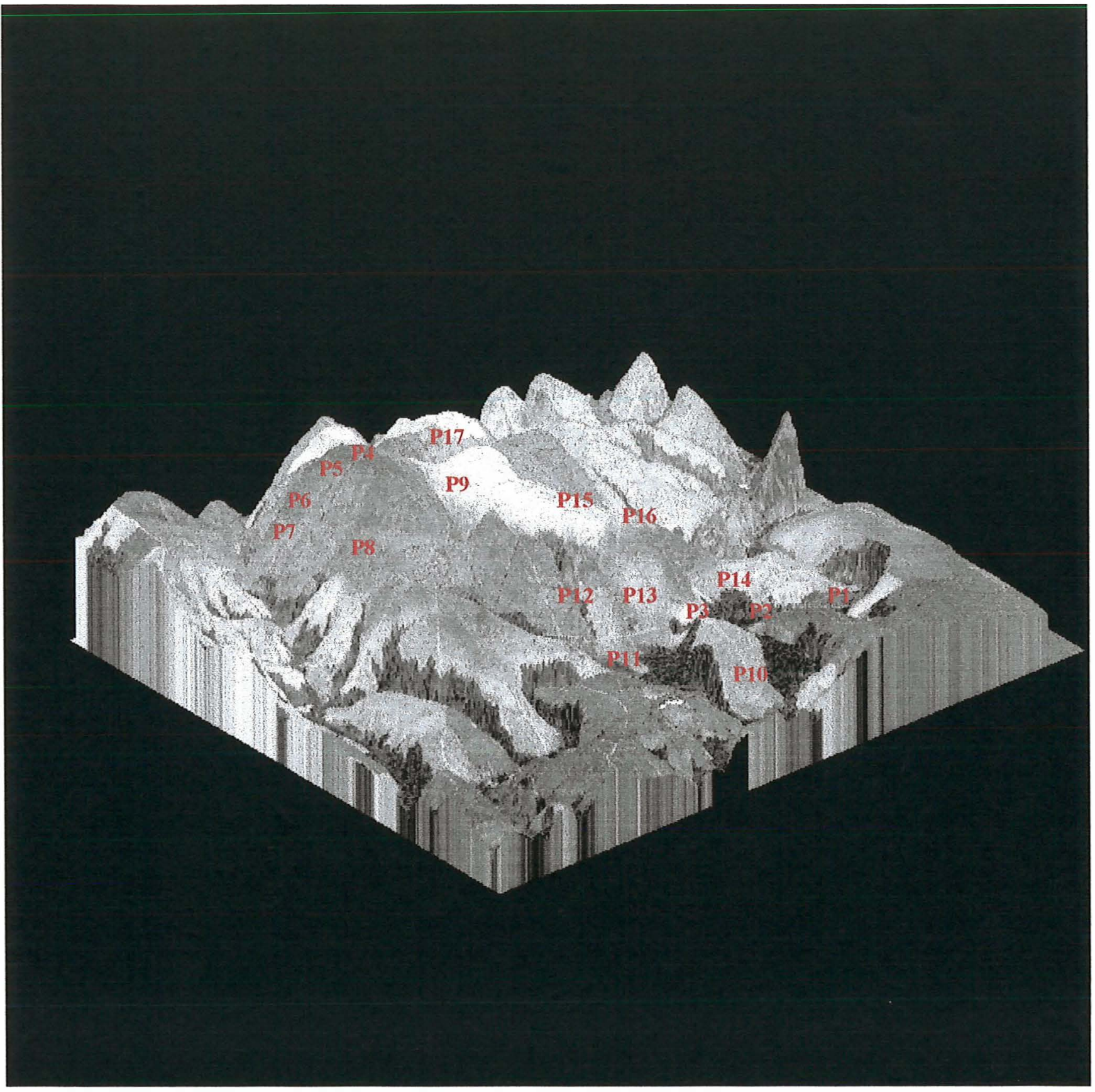

Figura 6 - Visualização da área de estudo em um modelo digital de elevação. P1- GLEISSOLO HÁPLICO Ta Distrófico típico; P2 ALISSOLO HIPOCRÔMICO Argilúvico abrúptico; P3 - CAMBISSOLO HÁPLICO Ta Eutrófico típico; P4 - NITOSSOLO VERMELHO Eutroférrico latossólico; P5 - CHERNOSSOLO HÁPLICO Óttico típico; P6 - CAMBISSOLO HÁPLICO Eutroférrico léptico; P7 - NEOSSOLO LITÓLICO Distrófico típico; P8 - CAMBISSOLO HÁPLICO Tb Distrófico léptico; P9 - NEOSSOLO REGOLÍTICO Distrófico típico; P10 - LATOSSOLO VERMELHOAMARELO Distrófico câmbico; P11 - CAMBISSOLO HÁPLICO Tb Distrófico típico; P12 - CAMBISSOLO HAPLICO Tb Distrófico típico; P13 ARGISSOLO VERMELHO Distrófico abrúptico; P14 - NEOSSOLO REGOLÍTICO Distrófico típico; P15 - CAMBISSOLO HÁPLICO Tb Distrófico típico; P16 - NITOSSOLO VERMELHO Eutrófico latossólico; P17 - ARGISSOLO AMARELO eutrófico abrúptico 


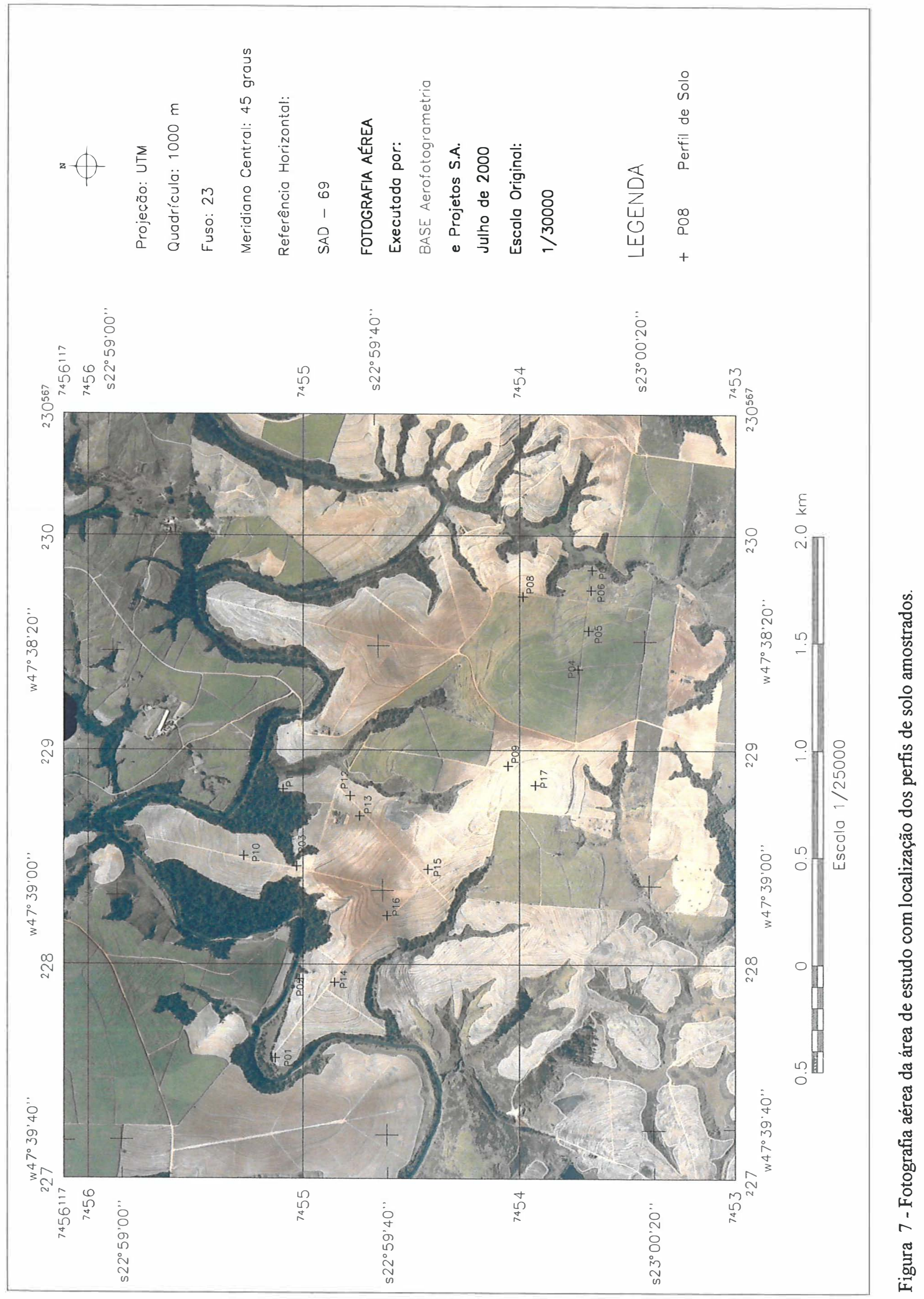




\subsubsection{Descrição dos solos estudados}

Foi realizada a descrição morfológica de 17 perfis de solo segundo Lemos \& Santos (1996). Tais perfis ocupam diferentes posições da paisagem (Figuras 6 e 7). As cores dos solos foram determinadas em laboratório com auxílio de colorímetro Minolta CR 300 (Figura 8 a), programado para leituras no sistema de cores de Munsell. Cores de mosqueados e horizontes variegados foram avaliadas em campo através da carta de cores de Munsell.

Posteriormente foi realizada a coleta e separação das amostras de terra de cada horizonte ou camada detectada nas descrições morfológicas. As amostras foram secas em estufa de ventilação forçada a uma temperatura constante de $50^{\circ} \mathrm{C}$ por um período de 48 horas. Foram então pesadas, destorroadas e peneiradas em peneira de $2 \mathrm{~mm}$. A fração menor que $2 \mathrm{~mm}$ foi separada em subamostras destinadas às análises fisicas, químicas, mineralógicas e radiométricas. A fração maior que $2 \mathrm{~mm}$ foi submetida a lavagem em água corrente para a determinação das frações calhaus e cascalhos, separadas por peneira de $2 \mathrm{~cm}$.

Os solos foram classificados de acordo como Sistema Brasileiro de Classificação de Solos (EMBRAPA, 1999).

Os locais dos perfis foram georreferenciamento utilizando o aparelho Global Positioning System, marca Trimble, modelo TDC1, Pró-XRS com correção diferencial pós-processada dos dados. 


\subsubsection{Análises de solos}

Para as análises químicas foram utilizados os métodos do Instituto Agronômico de Campinas (Camargo et al., 1986), compreendendo: determinação do pH em água, em . $\mathrm{KCl} 1 \mathrm{~N}$ e em $\mathrm{CaCl}_{2}$ determinação das bases trocáveis $\left(\mathrm{Ca}^{++}, \mathrm{Mg}^{++}, \mathrm{K}^{+}\right)$, soma de bases (SB) , capacidade de troca de cátions $(\mathrm{T})$, alumínio trocável $\left(\mathrm{Al}^{3+}\right)$, porcentagem de saturação por bases (V \%), porcentagem de saturação por alumínio (m \%), acidez potencial $\left(\mathrm{H}^{+}+\mathrm{Al}^{3+}\right)$, fósforo assimilável, matéria orgânica e carbono orgânico, determinação dos teores de $\mathrm{SiO}_{2}, \mathrm{Fe}_{2} \mathrm{O}_{3}, \mathrm{Al}_{2} \mathrm{O}_{3}, \mathrm{TiO}_{2}$ e $\mathrm{MnO}$ através de ataque por ácido sulfúrico, determinação dos índices $\mathrm{Ki}$ e $\mathrm{Kr}$.

Para as análises granulométricas foi utilizado o método do densímetro (Camargo et al., 1986) para separação das frações areia, silte e argila segundo a escala do Departamento de Agricultura dos Estados Unidos (USDA), utilizando hexametafosfato de cálcio $0,1 \mathrm{~N}$ e hidróxido de sódio $0,1 \mathrm{~N}$ como agentes dispersantes. $\mathrm{A}$ areia foi separada por tamisamento em 5 frações: areia muito grossa (de 2 a $1 \mathrm{~mm}$ ), areia grossa (de 1 a $0,5 \mathrm{~mm}$ ), areia média (de 0,5 a $0,25 \mathrm{~mm}$ ), areia fina (de 0,25 a $0,10 \mathrm{~mm}$ ), areia muito fina (de 0,10 a $0,05 \mathrm{~mm}$ ). A classificação textural foi feita de acordo com o triângulo de classes texturais do USDA.

\subsection{Obtenção dos dados espectrais}

Os dados espectrais foram obtidos em laboratório. Primeiramente as amostras foram acondicionadas em placas de Petri de $9 \mathrm{~cm}$ de diâmetro por $1,5 \mathrm{~cm}$ de altura e 
niveladas para que a superficie ficasse o menos rugosa possível (Figura 8 b). O sensor utilizado foi o Infra-Red Intelligent Spectroradiometer (IRIS; GER, 1996) com resolução espectral de $2 \mathrm{~nm}$ na faixa de 400 a $1.000 \mathrm{~nm}$ e $4 \mathrm{~nm}$ entre 1000 e $2500 \mathrm{~nm}$. A geometria para a aquisição dos dados seguiu os procedimentos de Galvão \& Vitorello (1998) e Demattê \& Garcia (1999). Utilizou-se como padrão de referência absoluta uma placa com 100 \% de reflectância (Labsphere, 1996). A razão entre o fluxo radiante espectral refletido pela superficie de uma amostra e o fluxo radiante espectral refletido pelo material de referência iluminado e visado nas mesmas condições que a superficie da amostra gera o fator de reflectância bidirecional (Nicodemos et al., 1977). A geometria é ilustrada na Figura 8c. Foram realizadas 3 leituras para cada amostra girando a placa de petri com a amostra cerca de $120^{\circ}$ a cada leitura para que fosse feita a varredura de diferentes pontos da amostra. O fluxo radiante espectral utilizado no cálculo do fator de reflectância foi a média aritmética das 3 leituras.

Os dados espectrais passaram por um sistema de filtragem e re-calibração do fator de reflectância, utilizando-se o software Conviris (Steffen, 1996). Os dados foram dispostos em gráficos do fator de reflectância em função do comprimento de onda gerando as "curvas espectrais". 

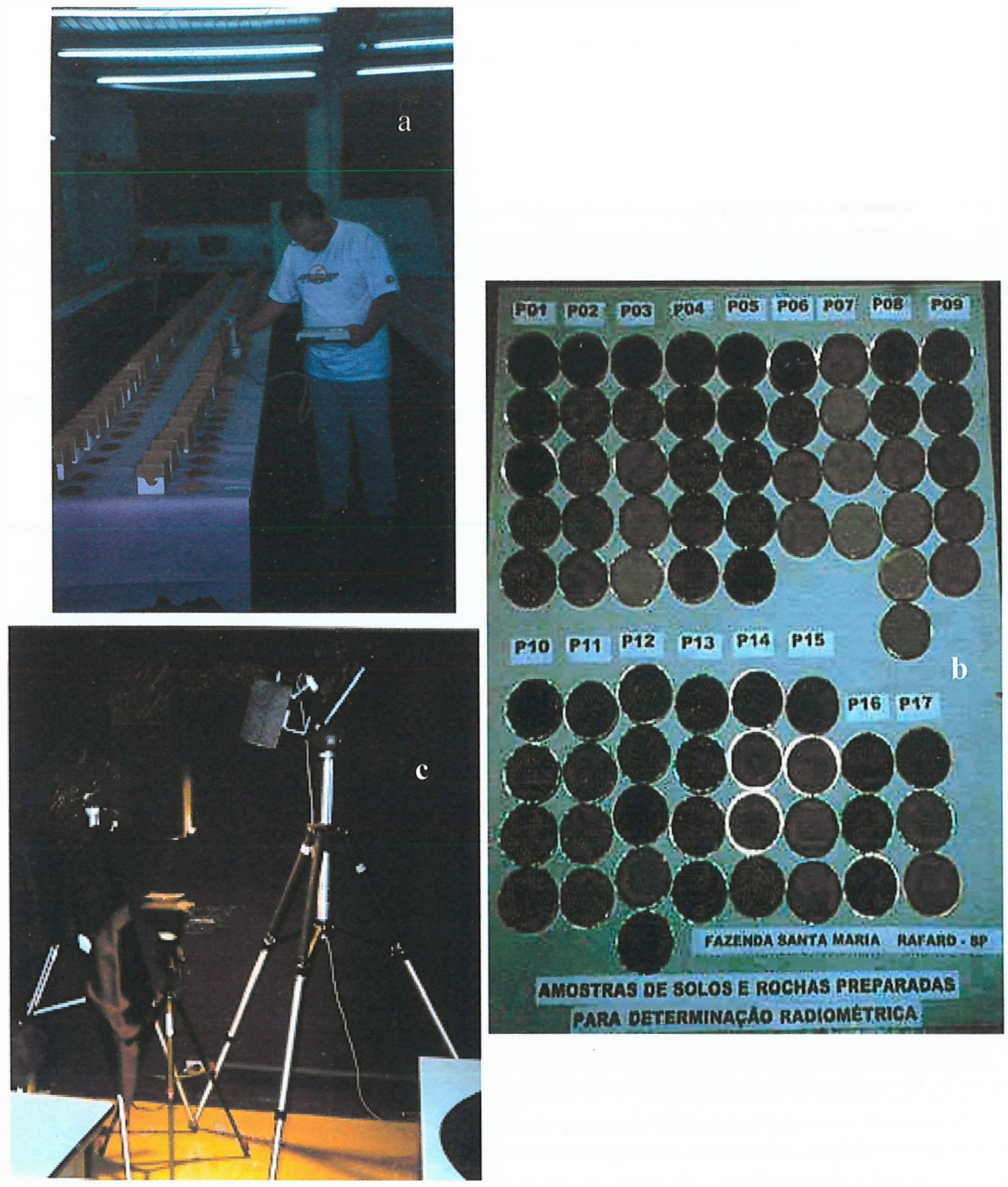

Figura 8 - Figura ilustrativa: a) obtenção da cor com colorímetro; b) amostras de terra preparadas para naálise radiométrica; c ) geometria de aquisição de dados espectrais com espectroradiômetro em laboratório. 


\section{RESULTADOS E DISCUSSÃO}

\subsection{Caracterização dos solos estudados}

Os dados analíticos e descritivos dos perfis dos solos estudados são apresentados nos Anexos A1 a A17. A posição dos perfis na paisagem pode ser verificada no mapa topográfico (Figura 5), no modelo digital de elevação (Fgira 6) e fotografia aérea (Figura 7). Ilustrações dos perfis, paisagens e os dados espectrais são apresentados nas Figuras 11 a 27.

O Perfil 1, pouco profundo, apresenta no campo um acentuado contraste entre os horizontes superficiais e os de subsuperfície em termos de diferença textural, tamanho, grau da estrutura e a consistência quando seco (Anexo Al).

A estrutura do B (Anexo Al) é de aparência maciça, grau de coesão forte e apresenta forma de blocos de tamanho grande e de grau forte. A consistência quando seca é dura a muito dura. A variação textural se dá em curto espaço passando de areia franca a franco arenoso, suficiente para a caracterização de um B textural, porém sem cerosidade, com uma transição abrupta e ondulada (Figura 11). Estes solos apresentam gleização a partir do horizonte $\mathrm{Bg}$, indicando ser este solo de baixa permeabilidade. $\mathrm{O}$ teor de argila do A é de $80 \mathrm{~g} \mathrm{~kg}^{-1}$ (Anexo A1) passando para $140 \mathrm{~g} \mathrm{~kg}^{-1}$ no B, muito 
próximo, portanto, do gradiente abrúptico que no caso seria de $80 \mathrm{~g} \mathrm{~kg}^{-1}$ para $160 \mathrm{~g} \mathrm{~kg}^{-1}$ de acordo com as especificações do Sistema Brasileiro de Classificação de Solos. Poderíamos neste caso enquadrar tal solo como um Planossolo incipiente mas como o sistema de classificação não discrimina tal situação ele foi enquadrado como GLEISSOLO HÁPLICO Ta Distrofico típico, ou seja: solos com Bg, com argila de alta atividade, com matiz mais amarelo que $5 \mathrm{YR}$ e tonalidade de 5.0 e intensidade menor que 4.

Quimicamente o perfil é distrófico porém, de argila constituída também de minerais 2:1, haja visto os resultados elevados do $\mathrm{Ki}$ de 3,43. Os teores de cálcio, magnésio e potássio do horizonte superficial são elevados devido as correções feitas para o uso deste solo (Anexo A1).

Tais solos na região ocorrem em relevo ligeiramente plano ( $5 \%$ declive), de baixada (Figuras 6 e 7), sofrendo a influência do lençol freático tendo o arenito como material de origem.

A descrição morfológica o Perfil 2 apresenta um elevado contraste textural entre os horizontes de superfície e de subsuperfície, passando de areia franca para francoargilo-arenoso evidenciando um caráter abrúptico, com teor de argila passando de 100 para $220 \mathrm{~g} \mathrm{~kg}^{-1}$ (Anexo A2). A estrutura do horizonte de subsuperfície é em blocos, de grau moderado e a espessura de $20 \mathrm{~cm}$.

Cerca da metade do volume deste horizonte e pequena parte do horizonte superficial está tomado por calhaus e cascalhos constituídos por seixos e fragmentos rochosos (principalmente arenito) de tamanho diversos concentrados de pedras (Figura 12 ). Esta linha de pedras acaba aflorando em situação de relevo mais baixa. 
Os resultados morfológicos e de textura permitem enquadrar o horizonte de subsuperficie como B textural, apesar de sua pequena espessura (Anexo A2). Os resultados químicos indicam ser este solo dessaturado, com saturação por bases abaixo dos $30 \%$ atingindo valores de $6 \%$ nas camadas mais inferiores. Por outro lado, a saturação por alumínio é extremamente elevada, atingindo valores por volta de $90 \%$ nos horizontes B e C. Como são solos pouco profundos o nível de intemperismo não é tão acentuado como evidenciado pelo índice $\mathrm{Ki}$ com valores acima de 2,5. A CTC caracteriza um complexo coloidal de alta atividade com presença de uma mineralogia mista.

A presença no perfil de um Bt, transição abrúptica, argila de atividade superior a $20 \mathrm{cmol} / \mathrm{Kg}$ de solo, alto conteúdo de alumínio superior a $4 \mathrm{cmol} / \mathrm{kg}$ de solo e saturação por alumínio superior a $50 \%$ no Bt, permitem enquadrar tal solo na classe dos Alissolos. Como o matiz não é de $7.5 \mathrm{YR}$, mas próximo, ele não pode ser enquadrado como caráter crômico, e sendo assim se enquadram como ALISSOLO HIPOCRÔMICO Argilúvico Abrúptico.

Na região estudada é muito comum nas encostas, a presença de solos profundos transitando para solos rasos e pedregosos. É este o caso do Perfil 3 cujos dados morfológicos indicam um solo raso $(A+B$ de $38 \mathrm{~cm})$ com o horizonte de subsuperfície de $16 \mathrm{~cm}$, com pequeno gradiente textural, no caso passando de $140 \mathrm{~g} \mathrm{~kg}^{-1}$ de argila da camada superficial para $160 \mathrm{~g} \mathrm{~kg}^{-1}$ no horizonte de subsuperfície (Anexo A3). No horizonte $\mathrm{B}$ já há forma de estrutura bem definida, em blocos de grau moderado. É comum na massa deste horizonte pequenos fragmentos de rocha de origem, no caso 
folhelho, indicado também pelo teor de silte na faixa de $300 \mathrm{~g} \mathrm{~kg}^{-1}$ na superfície e $220 \mathrm{~g}$ $\mathrm{kg}^{-1}$ no B.

Quimicamente são caracterizados por serem solos com elevada saturação por bases nos horizontes A e B. Não se levando em consideração o teor de matéria orgânica, a CTC deste solo tende a aumentar em profundidade, caracterizando inclusive um solo de argila de alta atividade principalmente pelo elevado $\mathrm{Ki}$ do horizonte $\mathrm{B}$, faixa de 5,24 (Anexo A3) o que se pode inferir uma mineralogia dominantemente de minerais de grade 2:1. De todos os solos estudados é o menos intemperizado.

Os resultados analíticos e morfológicos tendem a caracterizar um horizonte B incipiente a partir das seguintes evidências: não satisfaz os requisitos para caracterizar um Bt, apresenta dominância de cores brunadas e amareladas (Figura 13), textura franco arenosa, desenvolvimento de estrutura, porcentagem de argila pouco maior que o A, presença de pequenos fragmentos de rocha na massa do horizonte (Anexo A3). Tal solo foi enquadrado como sendo um CAMBISSOLO HÁPLICO Ta Eutrófico típico.

O Perfil 4 é caracterizado por ser um solo profundo (Figura 14), bem drenado, de textura argilosa a muito argilosa (Anexo A4), ocorrendo em local plano no topo da encosta, de cores avermelhada com matiz mais vermelho do que $2.5 \mathrm{YR}$. A variação do teor de argila em profundidade é muito pequena, variando de passando de $640 \mathrm{~g} \mathrm{~kg}^{-1}$ para $690 \mathrm{~g} \mathrm{~kg}^{-1}$ (Anexo A4).

A estrutura na camada superficial é completamente modificada pelo uso agrícola, com acentuado grau de compactação, podendo atingir inclusive a parte superior do segundo horizonte. Nos horizontes inferiores ela apresenta-se em blocos de grau moderado a forte, de tamanho médio a pequena, revestido pela cerosidade, grau este que 
tende a decrescer em profundidade, transformando-se em estrutura maciça porosa (Anexo A4), típica dos Latossolos.

Quimicamente são solos de boa fertilidade, com saturação de bases acima dos 65 $\%$ em todos os horizontes analisados. $\mathrm{O} \mathrm{Ki}$ dos horizontes inferiores é menor do que 2,0 caracterizando um solo de argila de baixa atividade, como pode ser verificado pelos valores da CTC (Anexo A4). Sendo assim, a mineralogia é constituída por caulinita e pelos óxidos principalmente de ferro. $\mathrm{O}$ teor de ferro total é superior a $230 \mathrm{~g} \mathrm{~kg}^{-1}$ nos horizontes inferiores (Anexo A4), reflexo do material de origem que no caso é representado por rochas básicas.

De acordo com os resultados analíticos e do exame morfológico (Anexo A4) o horizonte de subsuperficie pode ser caracterizado como sendo um B nítico ou seja: textura argilosa ou muito argilosa, sem incremento de argila de A para o B, argila de baixa atividade, estrutura em blocos com cerosidade, com transição gradual ou difusa. Trata-se de um NITOSSOLO VERMELHO Eutroférrico latossólico.

O Perfil 5 localizado na meia encosta de um relevo ondulado (Figuras 6 e 7) apresenta horizonte superficial, de $18 \mathrm{~cm}$ de espessura (Anexo A5) com transição clara e plana (Figura 15), uma estrutura modificada pelo uso agrícola, porém de intensidade de cor inferior a 3, com teor de carbono superior a $6 \mathrm{~g} \mathrm{~kg}^{-1}$ (Anexo A5). Tais características definem um horizonte A chernozêmico.

O horizonte de subsuperfície é caracterizado por ser um B incipiente devido a pequena espessura, $6 \mathrm{~cm}$, com estrutura em blocos de grau moderado e textura francoargilo-arenoso, e fragmentos pequenos de rocha de origem, basalto no caso, muito evidente em horizontes mais inferiores. Quimicamente são solos férteis, com saturação 
de bases acima de $80 \%$ e CTC elevada, caracterizando um solo de argila de alta atividade, haja visto os valores do $\mathrm{Ki}$, de 2,95 no $\mathrm{Bi}$. O teor de ferro total é superior a $150 \mathrm{~g} \mathrm{~kg}^{-1}$ (Anexo A5).

A presença do A chernozêmico coloca tal solo na categoria dos Chernossolos ou mais especificamente como CHERNOSSOLO HÁPLICO Órtico típico.

Os resultados do exame morfológico do Perfil 6 indicam um solo pouco espesso (Figura 16), localizado em meia encosta de um relevo ondulado (Figuras 6 e 7) apresentando uma drenagem moderada. O horizonte superficial, como na maioria dos solos desta região cultivado com cana de açúcar apresenta-se modificado pelo uso agrícola. A estrutura é de grau forte inclusive a consistência quando seca é dura (Quadro AP6). Na camada superficial encontra-se pequenos fragmentos de rocha de origem, siltitos no caso.

Observando-se com mais atenção os blocos estruturais do horizonte superficial nota-se revestimento de cerosidade. É um solo argiloso em ambos horizontes (Anexo A6). Em subsuprfície o horizonte é caracterizado por ser um B incipiente apesar das características de cerosidade serem de Bt. Entretanto, o pequeno gradiente trextural e a presença de minerais alteráveis na massa do $\mathrm{B}$ o caracterizam como $\mathrm{Bi}$.

Quimicamente são solos férteis, com saturação de bases superior a $50 \%$, teor de ferro de $18 \%$ e Ki de 2,15 (Anexo A6). Tal valor indica uma mineralogia constituída por dominância de caulinita com contribuição de minerais $2: 1$. A classificação final desta unidade é um CAMBISSOLO HÁPLICO Eutroférrico léptico. O termo léptico se refere a pequena espessura deste solo com contato lítico entre 50 e $100 \mathrm{~cm}$ de profundidade. 
Numa mesma encosta onde se encontram os perfis 5 e 6 pode ocorrer solos ainda mais rasos como o Perfil 7, caracterizado por uma associação de horizontes $\mathrm{Ap} / \mathrm{Cr}$ (Figura 17) sendo a rocha de origem representada por siltitos, R1 e R2 (Anexo A7).

$\mathrm{O}$ teor de argila é de $240 \mathrm{~g} \mathrm{~kg}^{-1}$ na superfície e de $27 \mathrm{~g} \mathrm{~kg}^{-1}$ na subsuperfície (Anexo A7) porém, com elevado teor de silte, superior a $400 \mathrm{~g} \mathrm{~kg}^{-1}$ em ambos horizontes. Como são solos rasos e pouco intemperizados o indice Ki é superior a 2,8 indicando mineralogia com contribuição de minerais 2:1. Entretanto, a saturação por bases é baixa e consequentemente o teor de alumínio é elevado. $\mathrm{O}$ fato de rochas, como siltitos, nesta região apresentarem variações na composição química é comum. Tal unidade foi classificada como NEOSSOLO LITÓLICO Distrofico típico.

O Perfil 8 é muito semelhante ao Perfil 6, diferindo entretanto, em relação aos seguintes aspectos: menor teor de argila (Figura 18, Anexo A8.) menor saturação de bases, menor teor de alumínio em profundidade, teor de ferro total inferior a $180 \mathrm{~g} \mathrm{~kg}^{-1}$, menor valor de $\mathrm{Ki}$ indicando um solo menos intemperizado com grande contribuição de caulinita (Ki próximo a 2,0 no horizonte Bi). Foi classificado como CAMBISSOLO HÁPLICO Tb Distrófico léptico.

O Perfil 9 é representado por ter o arenito como material de origem, este apresentando uma decomposição gradativa em profundidade com aspecto maciço (Anexo A9). Os dois primeiros horizontes são de textura arenosa (Anexo A9) com teores de argila inferior a $150 \mathrm{~g} \mathrm{~kg}^{-1}$ transitando diretamente sobre o C. A estrutura é fraca e se desfazendo em grãos simples (Figura 19). Tais características permitem enquadrar tal solo como um Neossolo. Os resultados químicos indicam ser um solo de 
baixa saturação de bases e de $\mathrm{Ki}$ na faixa de 2,0. Este solo foi classificado como NEOSSOLO REGOLITICO Distrófico típico.

Os trabalhos de campo indicaram ser o Perfil 10 localizado em relevo plano a suave ondulado (Figuras 6 e 7), ser um solo profundo, bem drenado (Figura 20), com uma textura pouco diferenciada em profundidade, franco-argilo-arenosa (Anexo 10), com grau fraco de estrutura.

Notou-se nos horizontes inferiores pequeno revestimento de argila nos agregados definidos como cerosidade. Entretanto, as características morfológicas destes horizontes são de uma massa latossólica. A espessura do solum mais o horizonte BC é inferior a $150 \mathrm{~cm}$ (Anexo A10). Quimicamente são solos de baixa fertilidade e álico em profundidade com um $\mathrm{Ki}$ inferior a 2,0 nos horizontes de sub superficie, indicando mineralogia mista, caulinita com óxidos. Foi classificado como LATOSSOLO VERMELHO-AMARELO Distrófico câmbico.

O Perfil 11 tem o arenito como material de origem, situado em local plano, $2 \%$ declive (Figuras 6 e 7). É um solo raso, com drenagem moderada a lenta. O teor de argila nos horizontes superiores é de 180 no Ap e $220 \mathrm{~g} \mathrm{~kg}^{-1}$ no B (Figura 21, Anexo A11).

As características do horizonte B entre elas a pouca espessura, a ausência de gradiente textural (Anexo A11) a presença de fragmentos de rocha o inclue como B incipiente. Quimicamente é um solo distrófico com $\mathrm{Ki}$ na faixa de 2,4. É um solo semelhante aos demais cambissolos distróficos aqui descritos.Sua classificação ficou como sendo um CAMBISSOLO HÁPLICO Tb Distrófico típico. 
Os resultados das análises morfológicas do Perfil 12 (Anexo A12) indicaram um solo moderadamente profundo, tendo como material de origem arenitos finos. A drenagem é moderada e a textura é arenosa na superficie passando para média na sub superfície. O gradiente textural é abruptico onde o teor de argila do A é de $120 \mathrm{~g} \mathrm{~kg}^{-1}$ (Anexo A12) passando para $240 \mathrm{~g} \mathrm{~kg}^{-1}$ no horizonte inferior o que associado com a presença de cerosidade caracteriza um Bt.

São solos álicos, com saturação por alumínio superior a $60 \%$ no B e com argila de alta atividade onde o Ki fica na faixa dos 2,3 no B (Anexo A12). Foi classificado como ALISSOLO HIPOCROMICO Argilúvico Abrúptico.

O Perfil 13 é caracterizado por apresentar um solo profundo (Figura 23), de drenagem moderada a boa, com cor avermelhada, grau moderado a forte de estrutura no B, com cerosidade forte. A variação do teor de argila entre o A e o B (Anexo A13) é alto indo de $330 \mathrm{~g} \mathrm{~kg}^{-1}$ para $720 \mathrm{~g} \mathrm{~kg}^{-1}$ no B indicando um horizonte textural.

A saturação por bases é superior a $50 \%$ e o Ki no B está na faixa de 1,9, indicando um solo dominantemente caulinítico. O teor de ferro total é de $13 \%$ podendo ser incluído na categoria dos ARGISSOLO VERMELHO Distrófico abrúptico (Anexo A13).

O Perfil 14 é um solo raso, com menos de $80 \mathrm{~cm}$ de espessura, tendo o arenito como material de origem (Figura 24). Devido a intensa atividade agrícola na região a transição do Ap para o B é confusa, havendo indícios de revolvimento do solo. É um solo arenoso com $120 \mathrm{~g} \mathrm{~kg}^{-1}$ de argila nas duas camadas, de baixa fertilidade e $\mathrm{Ki}$ na faixa de 2,5 no horizonte de subsuperficie (Anexo A24). É comum pequenos fragmentos de arenito na massa do horizonte de subsuperficie. Como a textura é areia franca, este 
horizonte não foi classificado como B incipiente. A classificação ficou como sendo um NEOSSOLO REGOLITICO Distrófico típico.

O Perfil 15 é semelhante ao 14 no que se refere a espessura e a posição que ocupa no relevo, meia encosta (Figuras 6 e 7) e ao material de origem. Difere, entretanto, nos seguintes aspectos: ser um pouco mais argiloso na subsuperfície, com a classe textural franco-arenosa, mínima para ser enquadrado como horizonte câmbico, ter saturação elevada por alumínio (Anexo A15). Foi classificado como CAMBISSOLO HÁPLICO Alumínico típico (Figura 25).

O Perfil 16 (Figura 26) é muito semelhante ao Perfil 4 inclusive na elevada saturação por bases, no elevado teor de ferro total e no Ki inferior a 2,0 (Anexo A16). Foi classificado na mesma categoria como sendo um NITOSSOLO VERMELHO Eutroférrico latossólico.

As características morfológicas do Perfil 17 (Anexo A17) indica um solo profundo com drenagem moderada ocorrendo em relevo ondulado. O horizonte de subsuperficie apresenta cores com matiz mais amarelada do que 5YR, com acentuado gradiente textural caracterizando um Bt . É um solo com alta saturação por bases, eutrófico, portanto (Anexo A17), argila de baixa atividade e Ki no Bt na faixa de 1,8 indicando uma mineralogia mista, caulinita e óxidos. Foi classificado como ARGISSOLO AMARELO Eutrófico abrúptico (Figura 27). 


\subsection{Caracterização descritiva do comportamento espectral dos solos}

Conforme descrito na revisão bibliográfica, existem dois métodos de avaliação descritiva das curvas espectrais. O primeiro deles originou-se de trabalho de Condit (1970), posteriormente complementado por Stoner \& Baumgardner (1981). Neste trabalho, determinaram 5 tipos de curvas, caracterizadas por padrões de formas diferenciadas e ilustradas na Figura 1. Posteriormente, com o intuito de iniciar tais procedimentos para os solos ocorrentes no Brasil, Formaggio et al. (1996) determinaram 4 padrões de curvas espectrais representativas dos solos do Estado de São Paulo (Figura 2).

Baseado nestes trabalhos e observando as curvas espectrais dos solos nas Figuras 11 a 27, estas são a seguir descritas. O enfoque principal da descrição e discussãio está relacionado às curvas determinadas por Formaggio et al. (1996) pois trabalharam com solos do Brasil e com a mesma metodologia do presente trabalho. Com o intuito de comparação, algumas relações são realizadas aos tipos de Stoner \& Baumgardner (1981), porém, deve-se lembrar que trabalharam com amostras de terra úmida. A Tabela

3 apresenta um resumo dos tipos de curva enquadradas de acordo com Formaggio et al. (1996) de cada perfil.

O Perfil 1 apresentou curvas espectrais do tipo 2 de Stoner e Baumgardner (1981), ou seja com formato côncavo em $700 \mathrm{~nm}$ e alta intensidade de reflectância (Figura 11). Em relação à curvas determinadas por Formaggio et al. (1996) assemelhamse ao tipo 2 (Tabela 3). Todas as curvas das amostras de terra ao longo do perfil são semelhantes quanto ao tipo. Porém, são diferentes ao se analisar detalhadamente suas 
formas. Observe que a curva da camada superficial apresenta tendência positiva, enquanto a de subsuperficie tendência horizontal. Tais curvas apresentam um formato reto ligeiramente côncavo na faixa dos $700 \mathrm{~nm}$.

O solo referente ao Perfil 2 (Figura 12), por sua vez, apresenta curvas da camada superficial do tipo 2 de Stoner \& Baumgardner (1981) e tipo 2 (Tabela 3) de Formaggio et al. (1996). Em subsuperfície, porém, pode-se detectar diferenças, passando para os tipos 3 e 4, respectivamente, caracterizadas pelas feições de absorção mais acentuadas em 1400 e 1900 nm devidas às vibrações moleculares da água + $\mathrm{OH}^{-}$e água, respectivamente (Lindberg \& Snyder, 1972). Isso ratifica observações preliminares de Demattê (1995) para o qual os tipos de curvas diferenciavam amostras de terra das camadas superficiais e subsuperficiais.

O Perfil 3 (Figura 13) também apresentou diferenças descritivas (de acordo com os autores citados anteriormente) entre as amostras de superficie e subsuperfície (Tabela 3).

O perfil 4 (Figura 14), por sua vez, um Nitossolo, apresentou curvas típicas e devidamente enquadradas nas dos tipos 5 e 1 dos autores citados (Tabela 3). São curvas com baixa intensidade de reflectância, tendência horizontal e feições pouco nítidas. Estas curvas assemelham-se às determinadas, para o mesmo solo, por Epiphanio et al. (1992) e Demattê et al. (1998b), estudando solos do Estado de São Paulo

As curvas espectrais do Perfil 5 (Figura 15), não apresentam diferenças quanto aos tipos de curvas dos autores citados, todas do tipo 5 ou 1. Mais uma vez, porém, a observação mais detalhada das curvas apresenta diferenças entre as das camadas 
superficiais e subsuperficiais. A curva do horizonte $C$, por exemplo apresenta uma feição notadamente diferenciada em relação à da camada superficial.

O Perfil 6, com curvas espectrais representativas dos Cambissolo (Figura 16), demonstram grande diferença entre os dados de solo e rocha, o que ratifica o observado por Demattê et al. (1999) e Demattê \& Garcia (1999). Ou seja, as curvas espectrais de rochas apresentam intensidades de reflectância mais elevadas, ao contrário das curvas de solos, devido à presença de minerais primários no material de origem, que normalmente aumentam a intensidade de reflectância (Mathews et al., 1973a).

As curvas espectrais de um Neossolo são apresentadas na Figura 17. São todas do tipo 4 (Tabela 3) de Formaggio et al. (1996), apresentando feições de absorção fortes em 1400 e 1900 nm com tendência horizontal e alta intensidade de reflectância. As curvas espectrais das diferentes profundidades não diferem descritivamente entre si.

As curvas espectrais do Cambissolo Háplico, horizontes Ap e Bi (Figura 18) são do tipo 5 de Stoner \& Baumgardner (1981). Novamente, as curvas espectrais das rochas apresentam maior intensidade de reflectância. Isso ocorre devido aos minerais das rochas estarem em um estado pouco avançado de intemperismo. Além disso, as curvas representam rochas e não solos, não apreesntando, por exemplo matéria orgânica em níveis tão elevados quanto nas amostras de terra. A matéria orgânica, conforme verificado por Henderson et al. (1992) absorve energia, diminuindo a intensidade de reflectância das amostras de terra.

As curvas epectrais do Perfil 9 (Figura 19) apresentam alta intensidade de reflectância e são descritivamente diferentes as das camadas superficial e subsuperficial. Observe que a curva do horizonte Ap não apresenta a concavidade centrada em $850 \mathrm{~nm}$, 
ao contrário das demais curvas. Isso ocorre devido, principalmente, à presença de matéria orgânica na camada superficial. De acordo com Formaggio et al. (1996) a primeira seria do tipo 2 e a segunda do tipo 4 (Tabela 3).

A curva da camada superficial do Latossolo Vermelho Amarelo (Figura 20), seria do tipo 3 de Formaggio et al. (1996). A intensidade na faixa de 0,5 e a tendência positiva e ascendente da curva de 600 a 1300, aliada a feição moderada em $850 \mathrm{~nm}$, enquadram as curvas subsuperficiais no tipo 4 (Tabela 3 ).

A curva da camada superficial do Perfil 11 (Figura 21), por sua vez, é típica do tipo 2, enquanto às do horizonte $\mathrm{C}$ do tipo 4, de acordo com Formaggio et al. (1996). Apesar de que as curvas descritivas destes autores referem-se a horizontes de solos e não transições como no caso do horizonte C.

O Perfil 12 (Figura 22) demonstra a convexidade em $800 \mathrm{~nm}$ típica das curvas tipo 2 de Stoner \& Baumgardner (1981), bem como tipo 2 (Tabela 3) de Formaggio et al. (1996). As curvas de subsuperfície foram discriminadas das de superfície sendo do tipo 3 (Tabela 3)

O Perfil 13 (Figura 23) apresenta curvas espectrais semelhantes em todos os horizontes, tipo 1 de Formaggio et al. (1996). São curvas semelhantes às obtidas por Demattê et al. (2000) para os Podzólicos Vermelho-Escuros da região de Lençóis Paulista, SP e concordam com dados de Epiphanio et al. (1992).

O Neossolo Regolítico (perfil 14) apresenta curvas absolutamente distintas entre o horizonte (Tabela 3) Ap e os horizontes C posteriores, passando do tipo 2 para o 4 . A discriminação das curvas entre os horizontes pelos tipos, concorda com resultados de Demattê (1995). 
As curvas espectrais do Perfil 15 (Figura 25) é semelhante ao Cambissolo anteriormente descrito e concordam com dados de Epiphanio et al. (1992).

O Nitossolo Vermelho (Figura 26), devido aos altos teores de ferro e óxidos como a hematita, apresentam curvas espectrais tipo 5 de Stoner \& Baumgardner (1981) e são devidamente enquadradas no tipo 1 (Tabela 3) de Formaggio et al. (1996). Curvas bem semelhantes foram obtidas por Demattê (1999) para o mesmo solo.

As curvas espectrais do Perfil 17 (Figura 27), mostra diferenças entre as camadas superficial e subsuperficial. O horizonte $\mathrm{A}$, devido aos maiores teores de matéria orgânica, apresenta-se sem a concavidade em $850 \mathrm{~nm}$, formato convexo com tendência ascendente (Tipo 2). Ao contrário, a curva do horizonte Bt tem fortes feições em 850, 1400 e $1900 \mathrm{~nm}$ (Tipo 4) de Formaggio et al. (1996). 


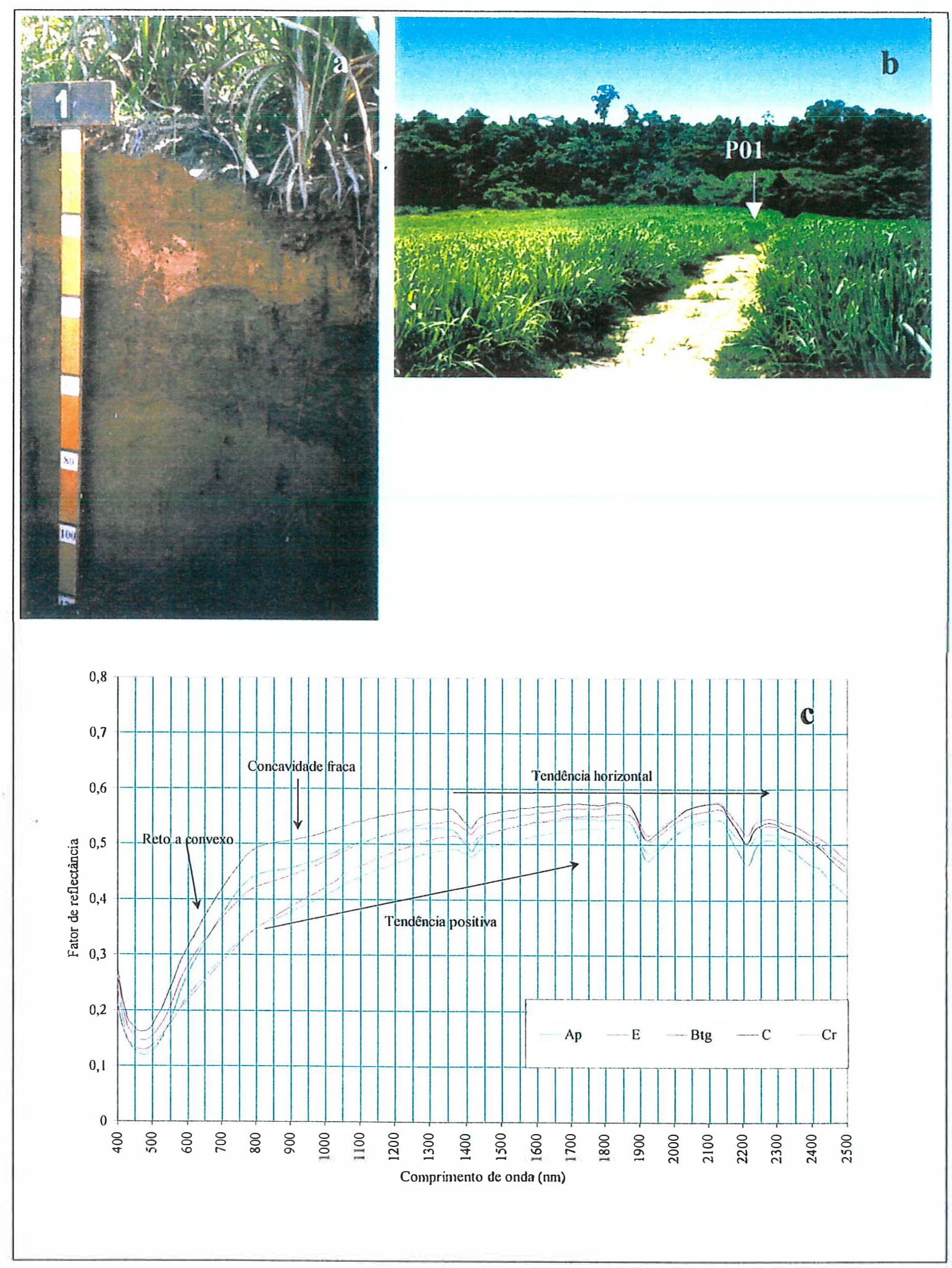

Figura 11 - Fotografia do Perfil l GLEISSOLO HÁPLICO Ta Distrófico típico e de seu local de ocorrência e curvas espectrais de amostras do mesmo perfil. 


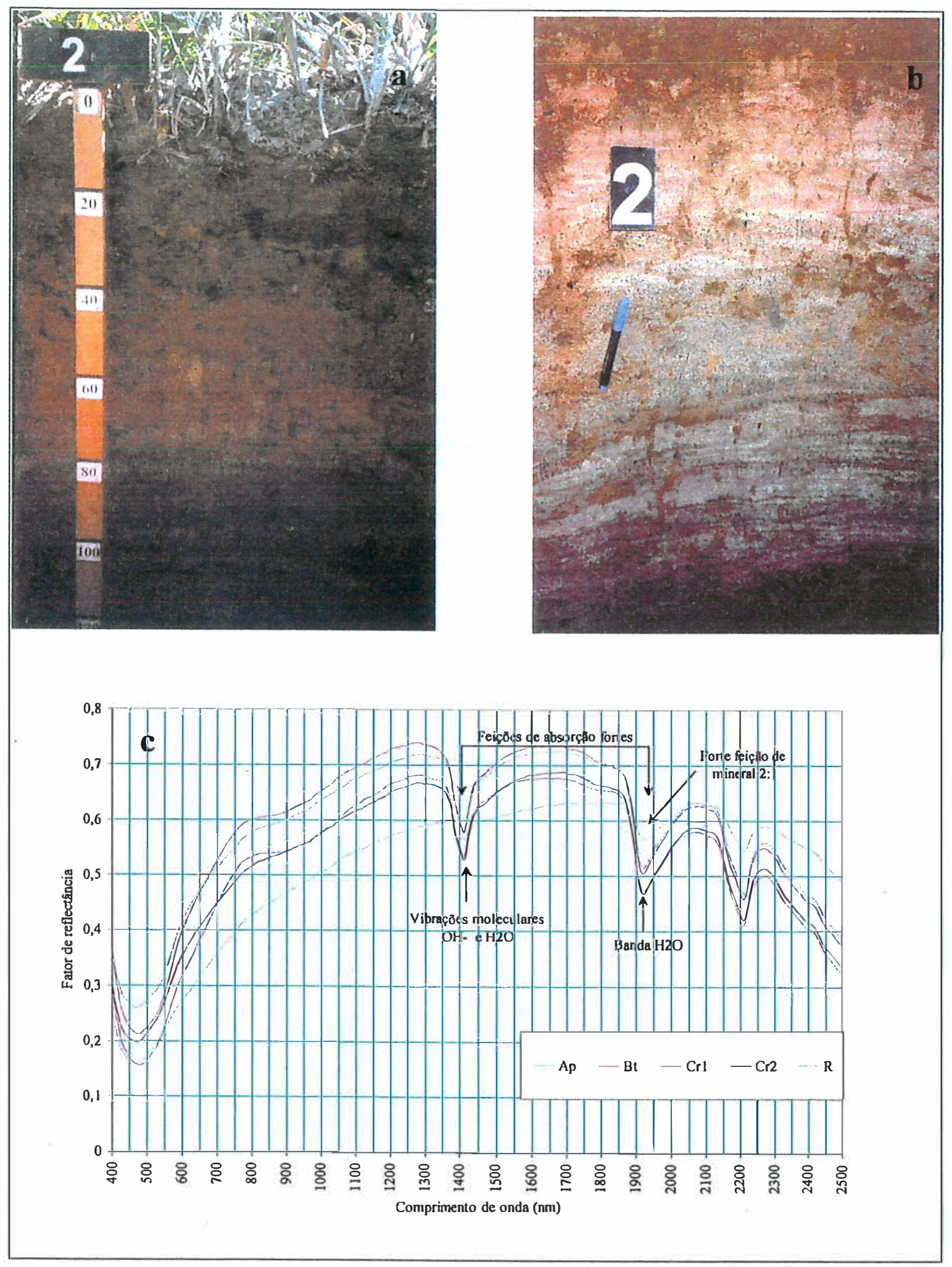

Figura 12 - Fotografia do Perfil 2 - ALISSOLO HIPOCRÔMICO Argilúvico abrúptico, detalhe da rocha sob o solum e curvas espectrais das amostras do mesmo perfil 

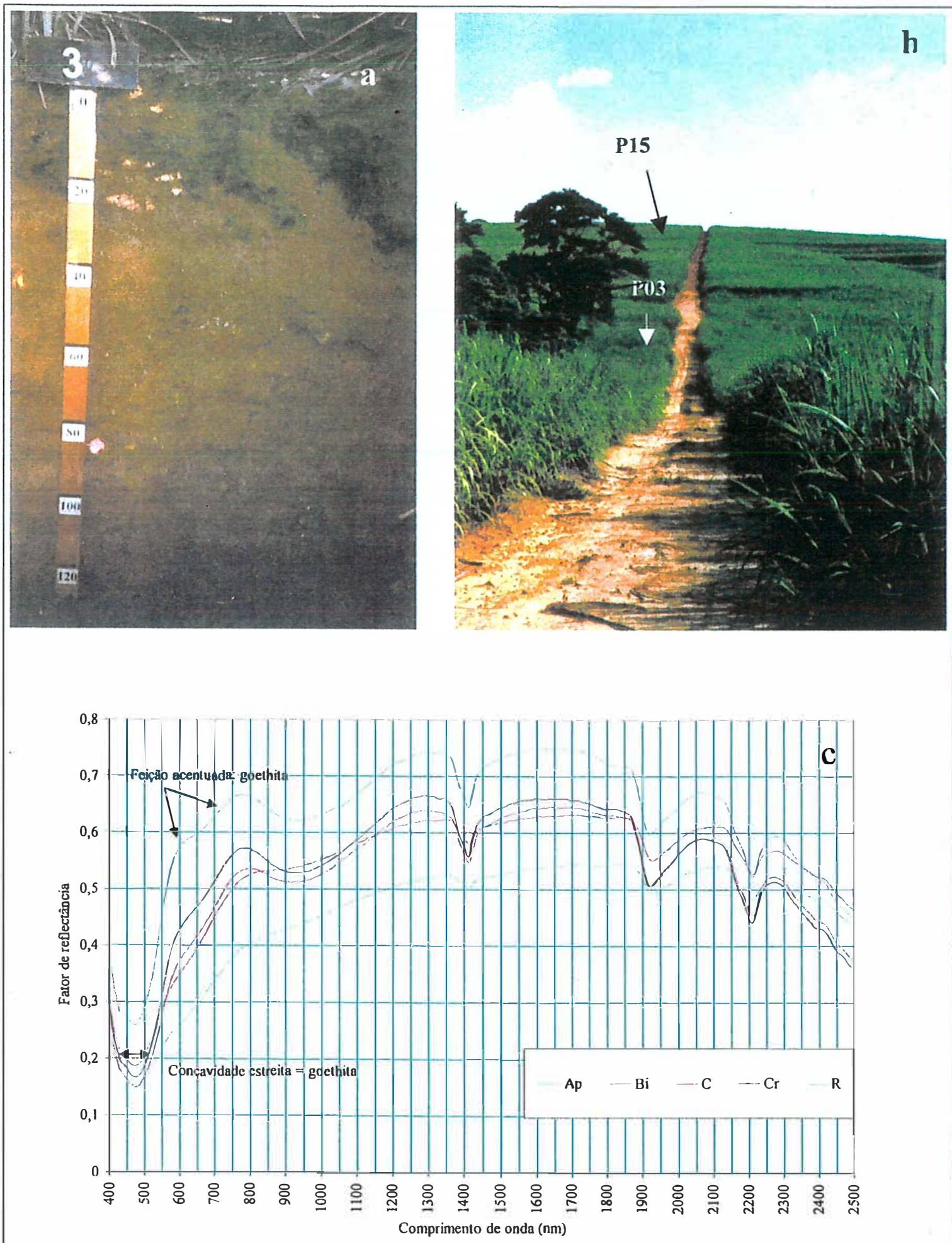

Figura 13 - Fotografia do Perfil 3 - CAMBISSOLO HÁPLICO Ta Eutrófico típico, sua localizaçào na pasiagem e curvas espect rais de amostras do mesmo perfil 


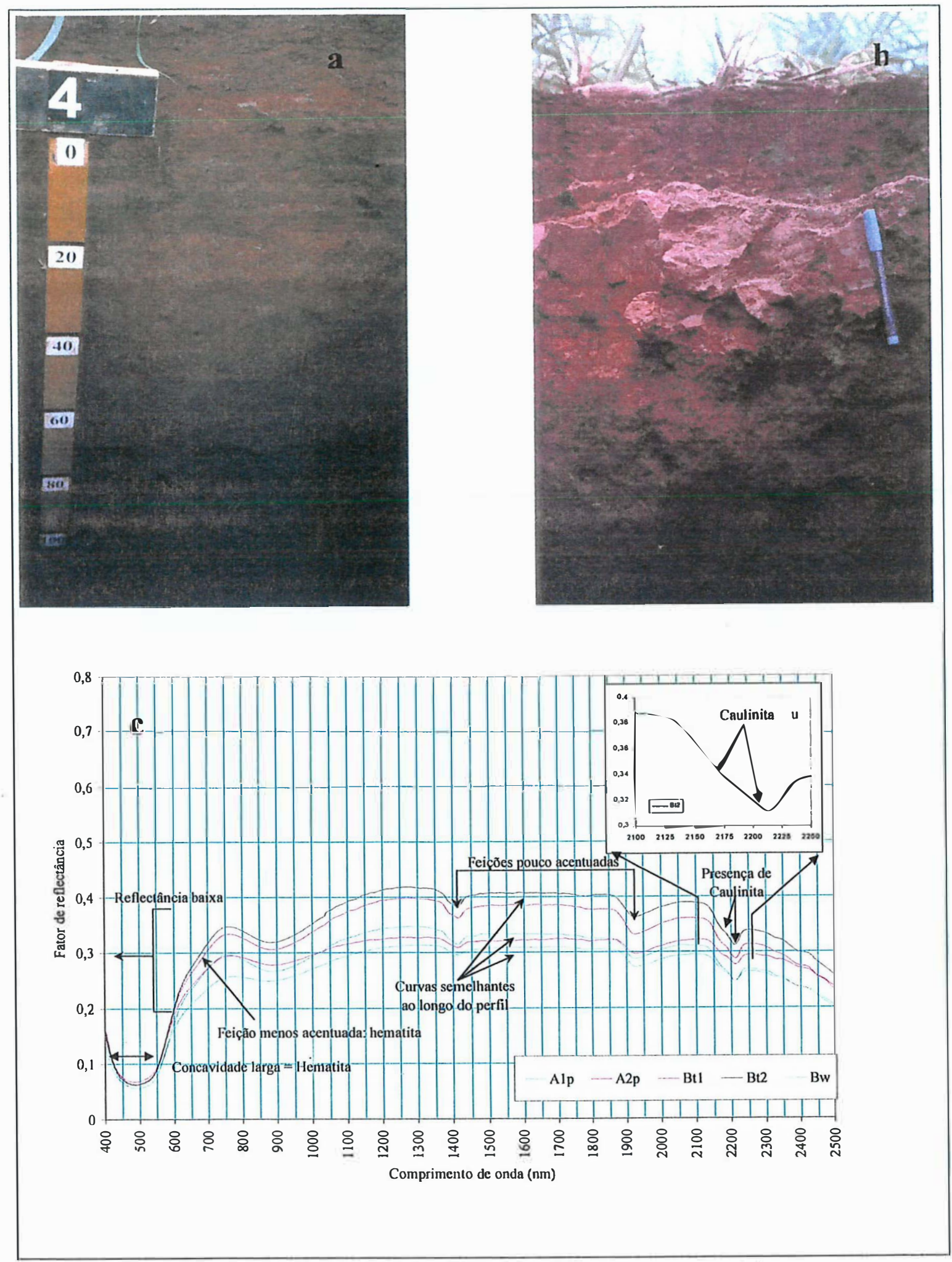

Figura 14 - Fotogralia do Perfil 4 - NITOSSOLO VERMELHO Eutroférrico latossólico, detalhe do mesmo perfil mostrando cainada compactada e curvas espectrais de amostras do mesmo perfil. 

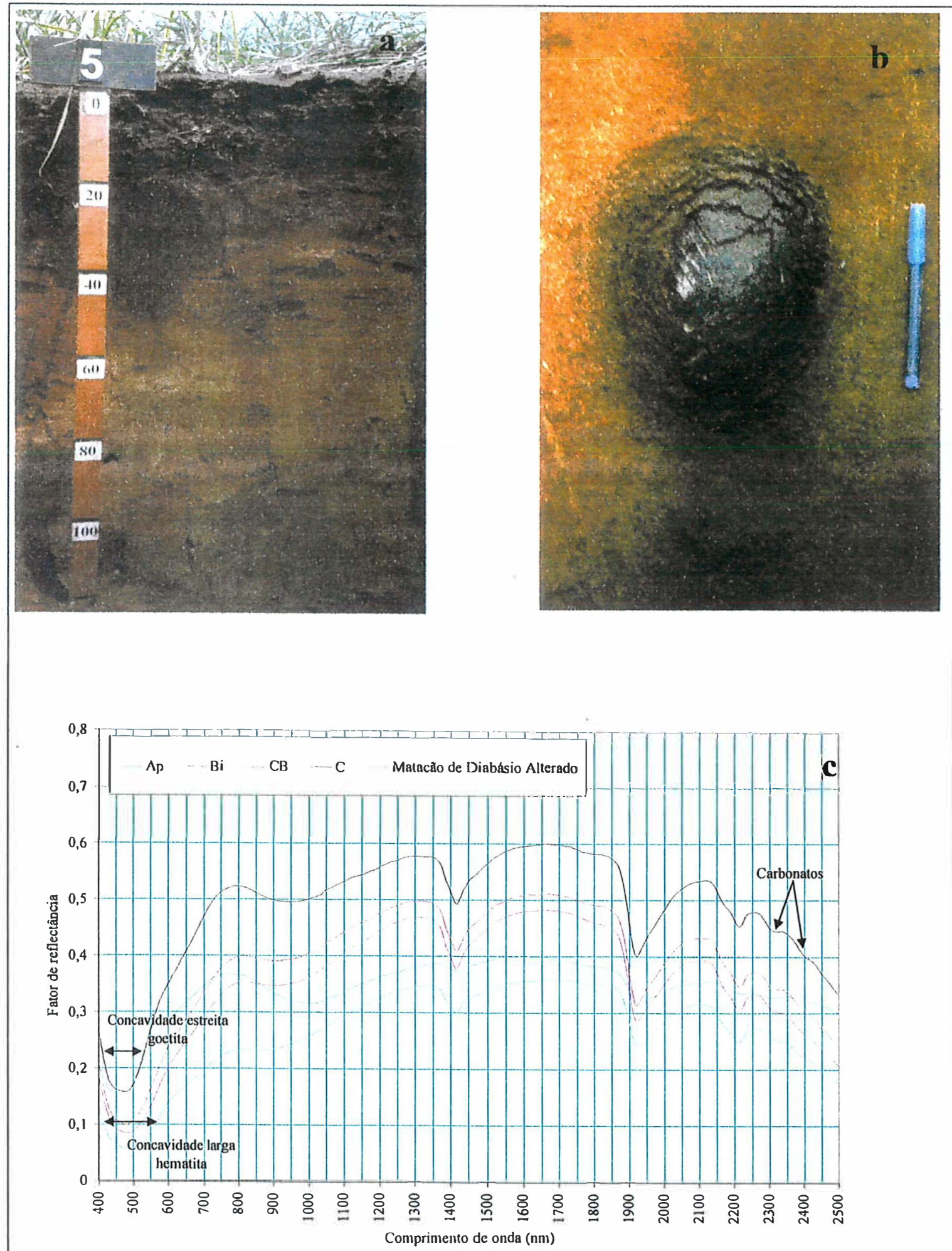

Figura 15 - Folografia do Perfil 5 - CHERNOSSOLO HÁPLICO Órtico típico, detalhe de diabásio alterado e curvas espectrais de amstras do mesmo perfil 

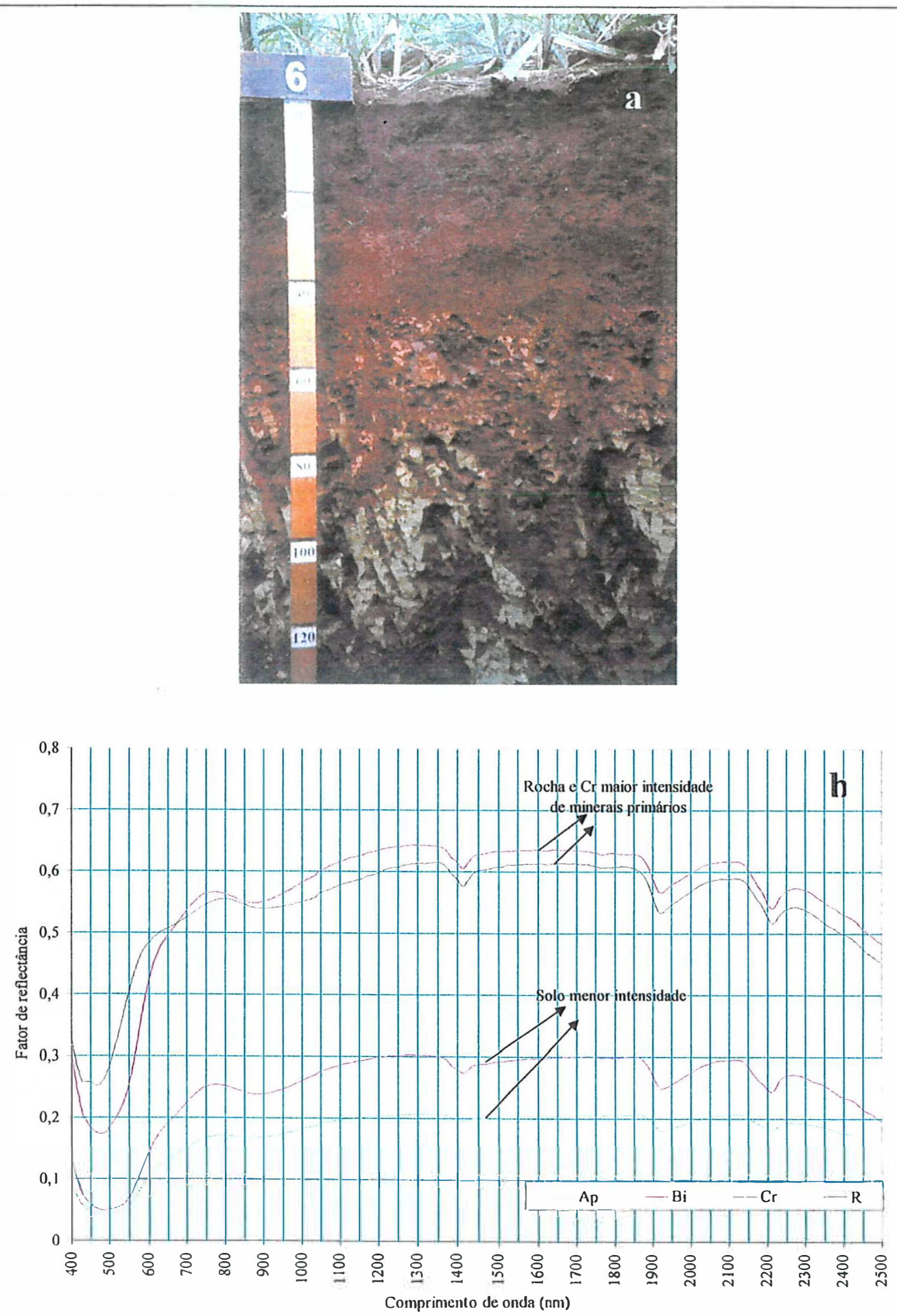

Figura 16 - Folografia do Perfil 6 - CAMBISSOLO HÁPLICO Eutroférrico léptico e curvas espectrais de amostras do mesmo perlil 

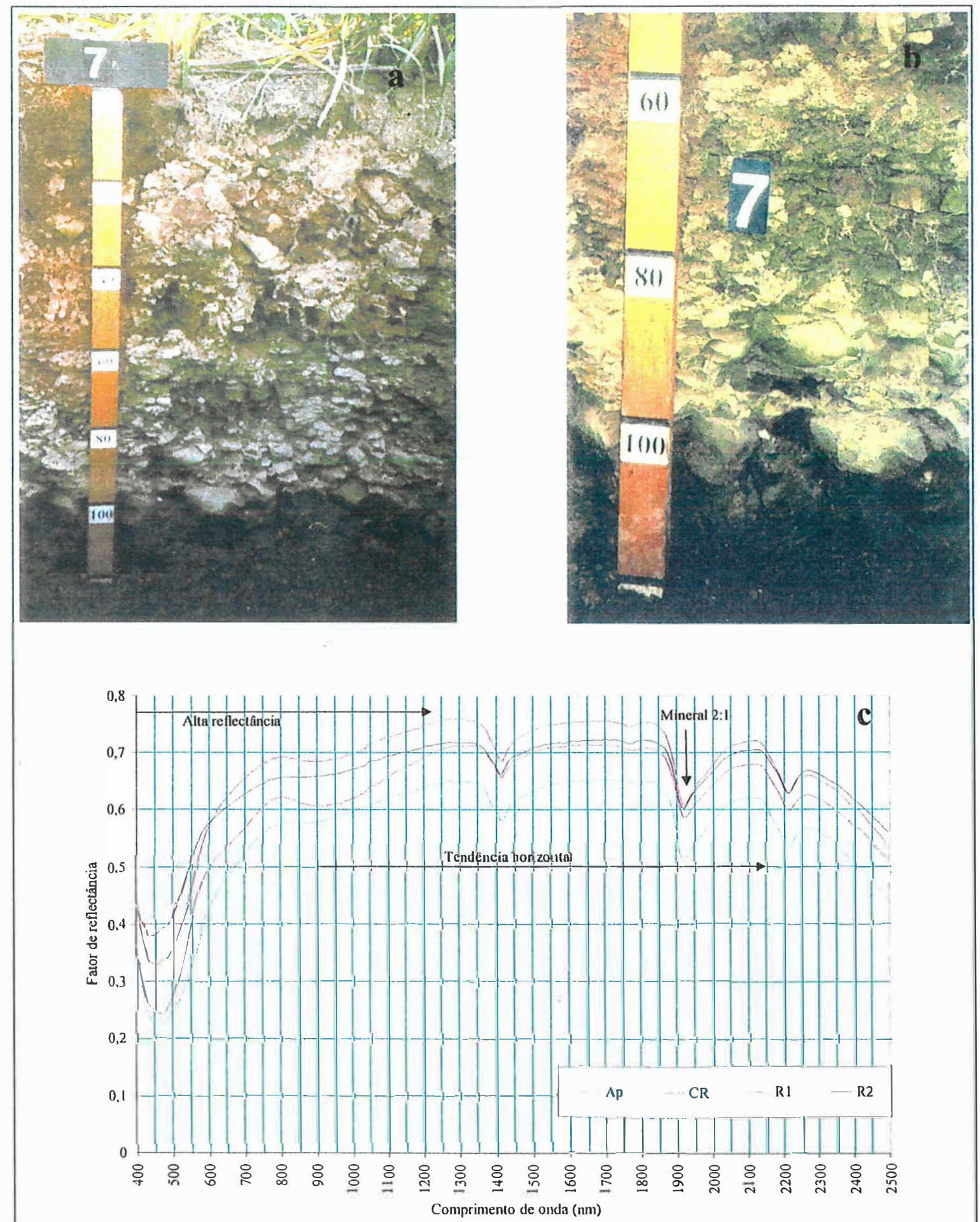

Figura 17 - Folografia do Perfil 7 - NEOSSOLO LITÓLICO Distrófico típico, detalhe da rocha sob o perfil e curvas espectrais de amostras do mesmo perfil 


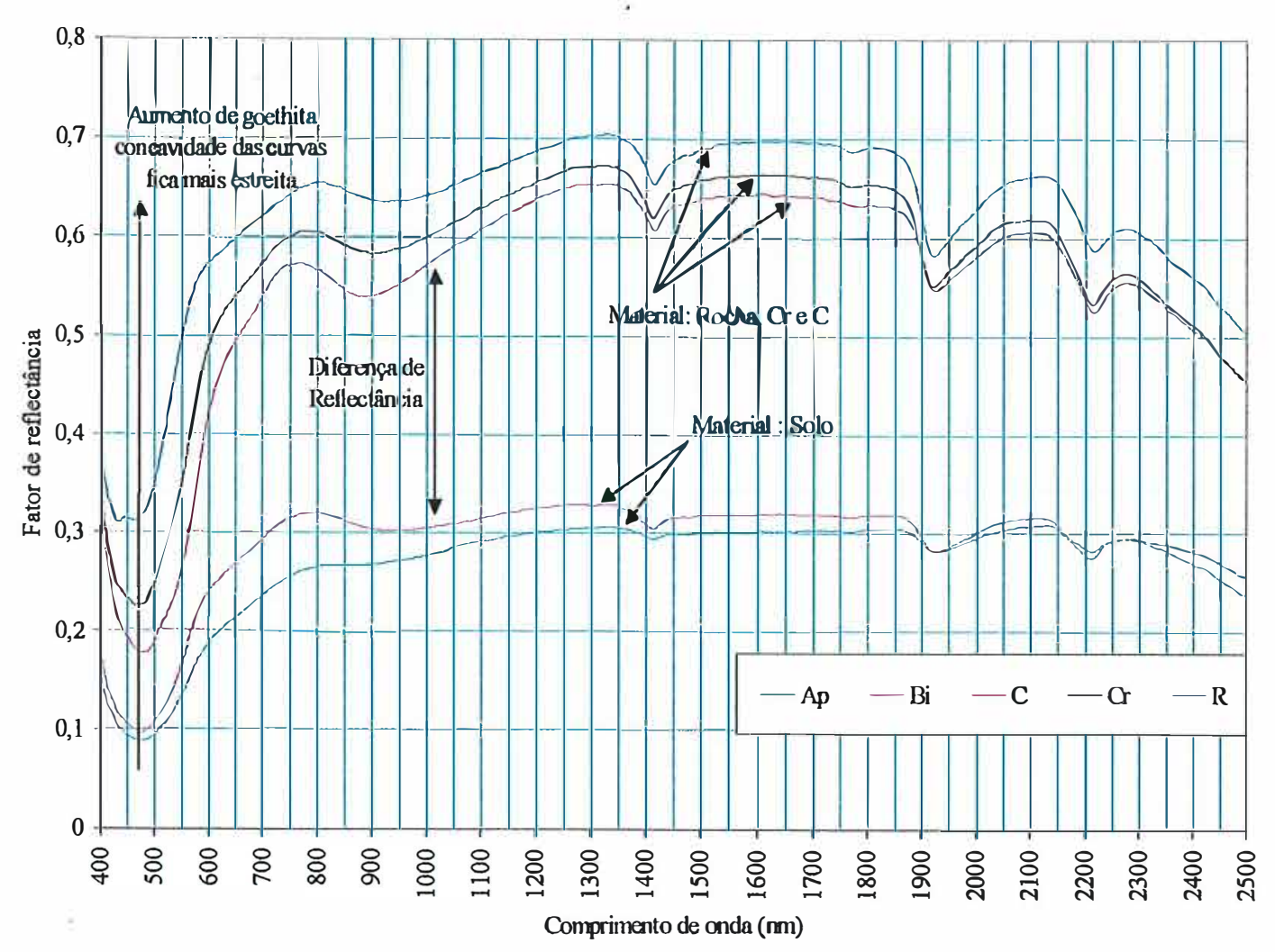

Figura 18 - Curvas espectrais das amostras dos horizontes do CAMBISSOLO HÁPLICO $\mathrm{Tb}$ Distrófico léptico. 


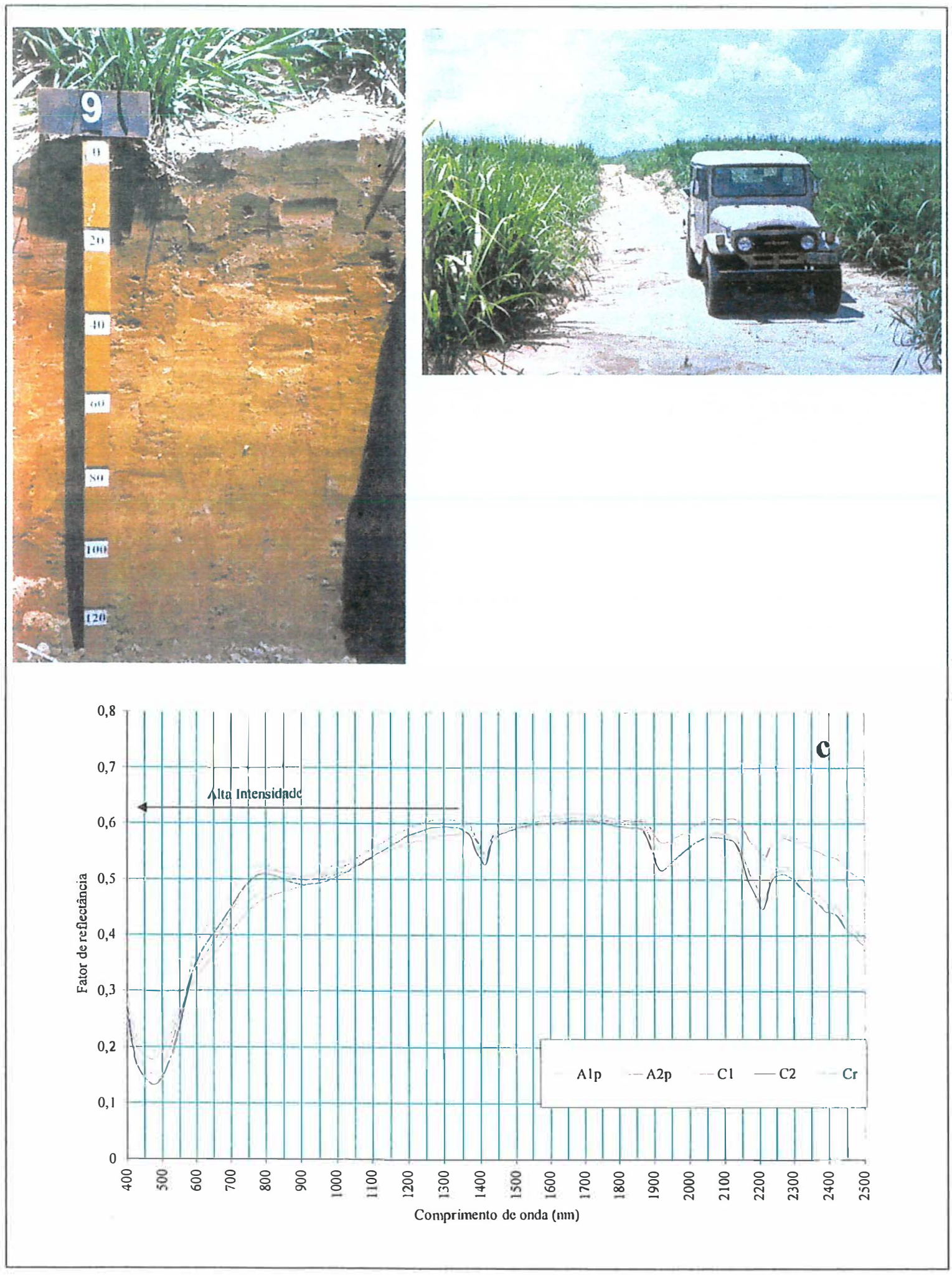

Figura 1) - Folografia do Perfil ) - NEOSSOLO REGOLÍTICO Distrófico lípico. local de ocorrência do perfil c curvas espectrais de amostras do mesmo perfil. 


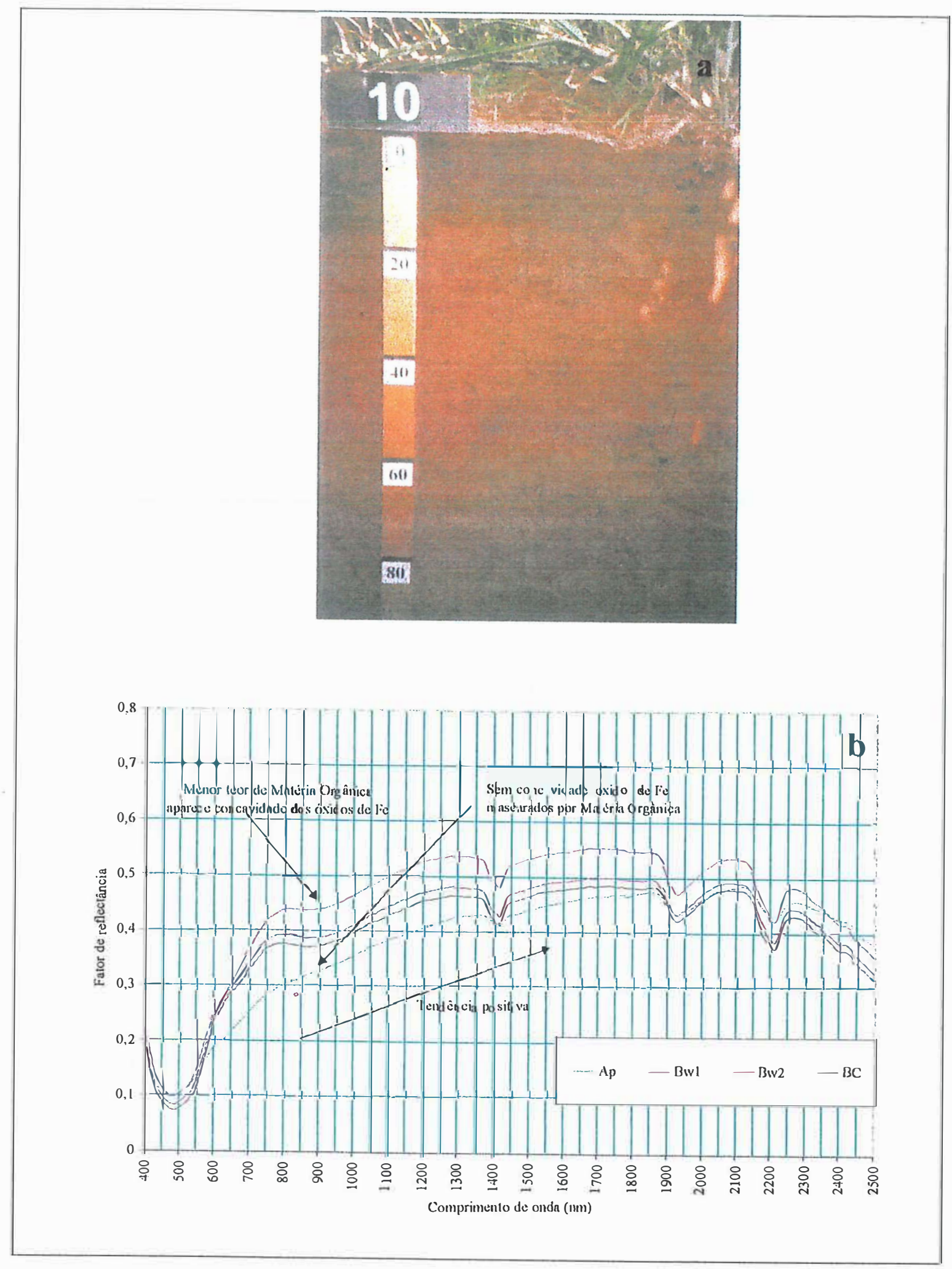

Figura 20) - Fotografia do Perfil l() - LATOSSOLO VERMELHO-AMARELO Distrófico câmbico c curvas espectrais de amostras do mesmo perfil. 

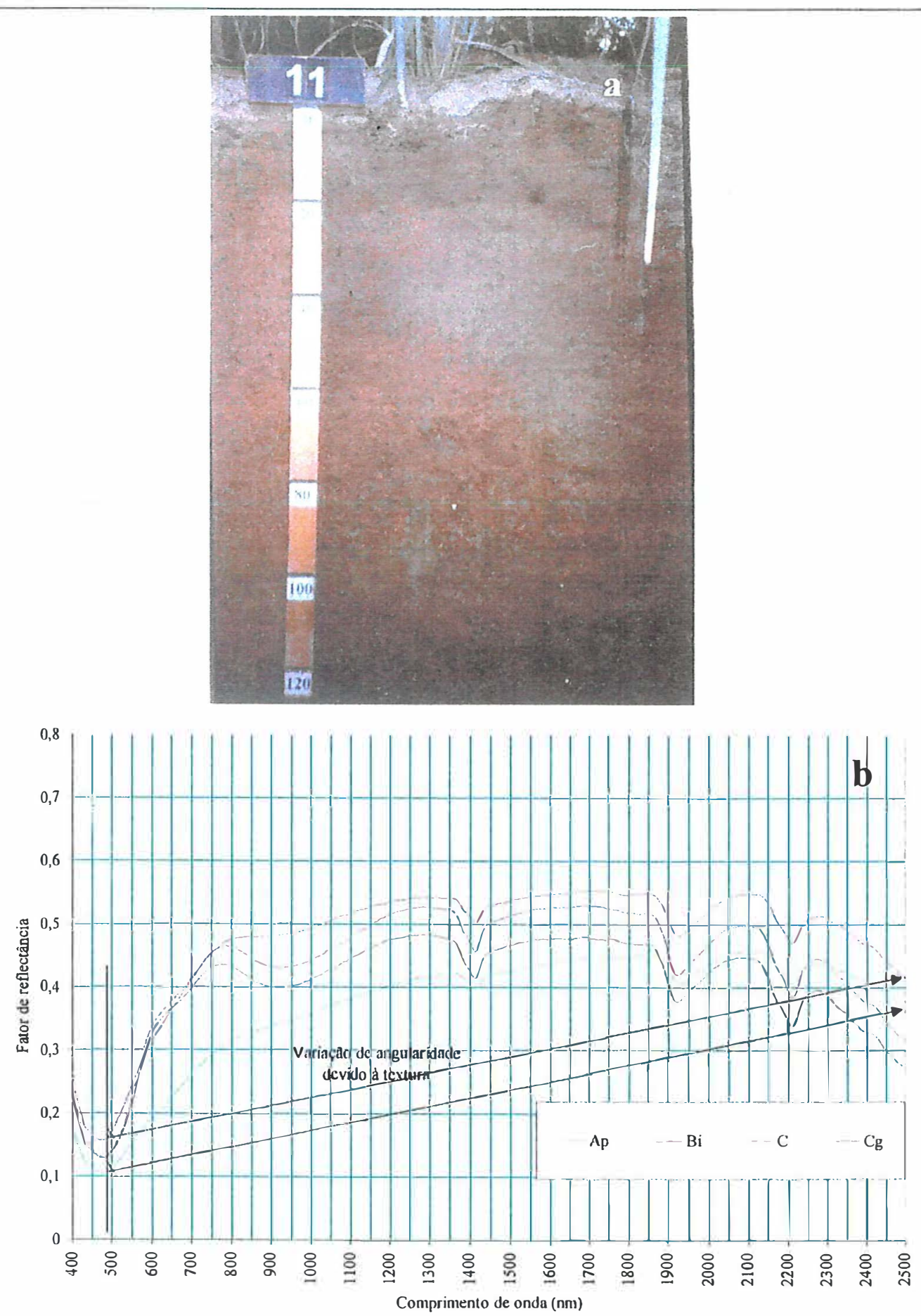

Figura 21 - Folografia do Perfil II - CAMBISSOLO HÁPLICO Tb Distrófico lípico c curvas espectrais de amosiras do mesmo perfil. 


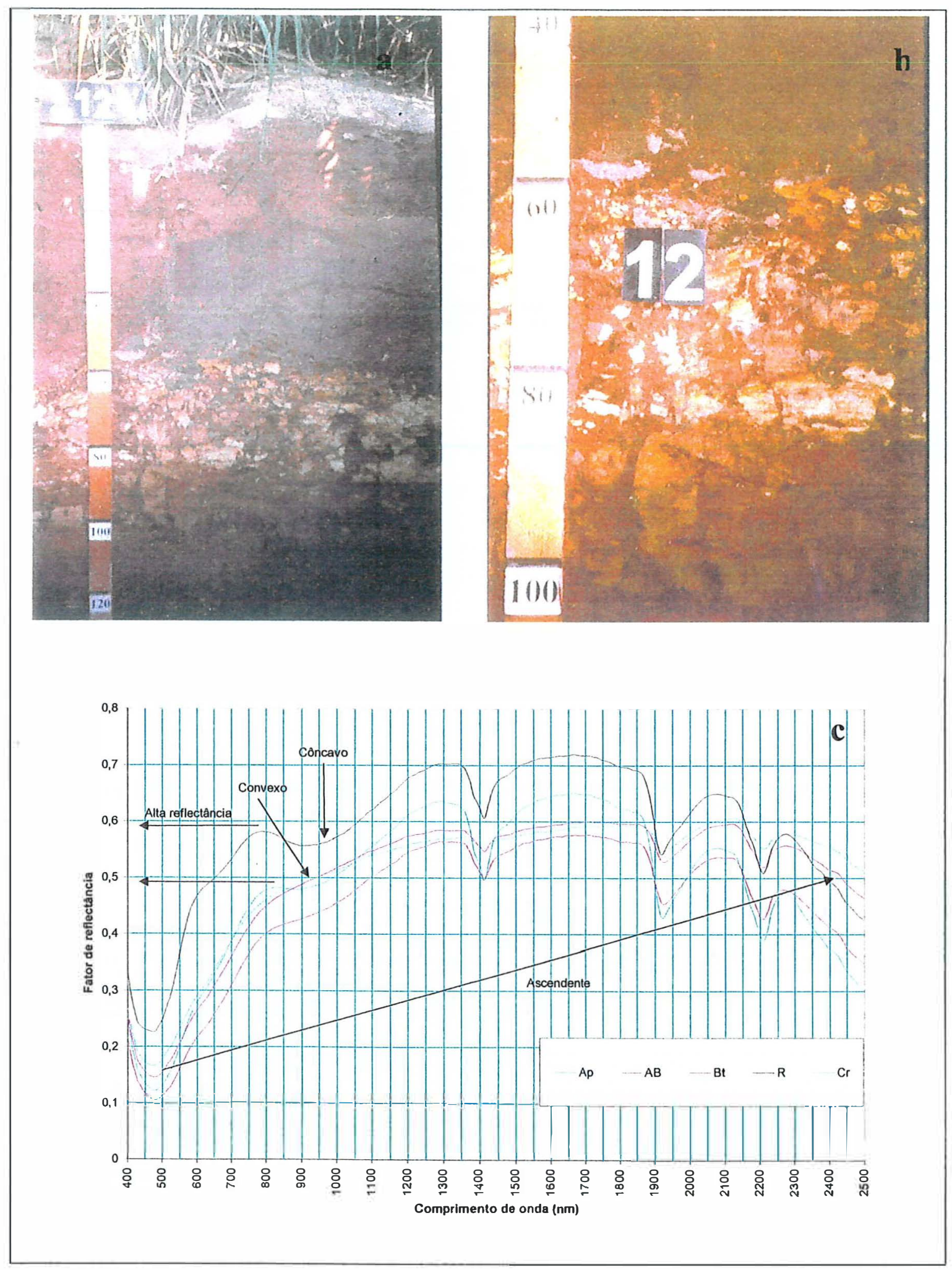

Figura 22 - Folografia do Perfil 12 - CAMBISSOLO HAPLICO Tb Distrófico Típico e curvas espectrais 

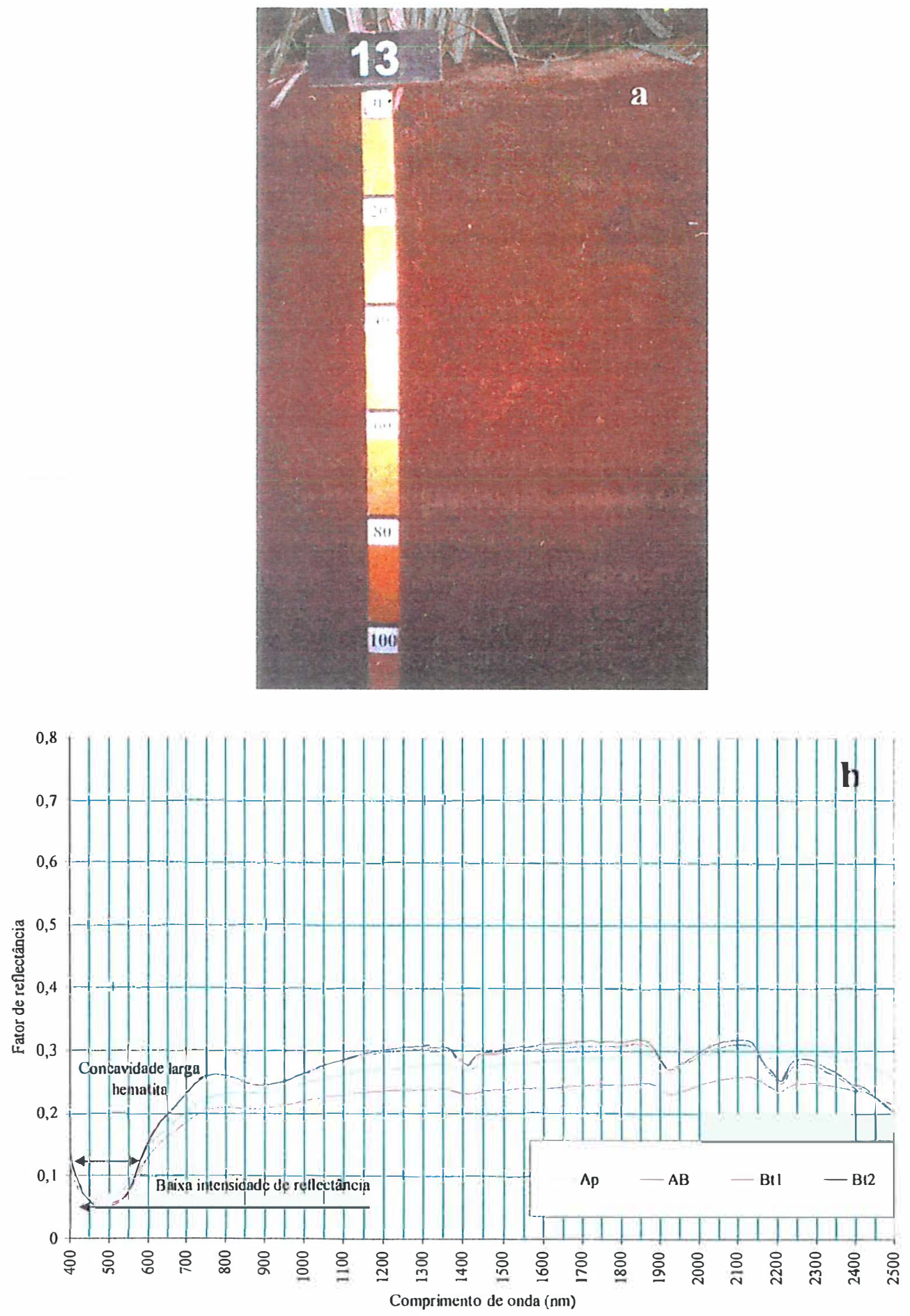

Figura 23 - Fotografia e curvas espectrias do Perfil 13 - ARGISSOLO VERMELHO Distrófico Abrúptico 


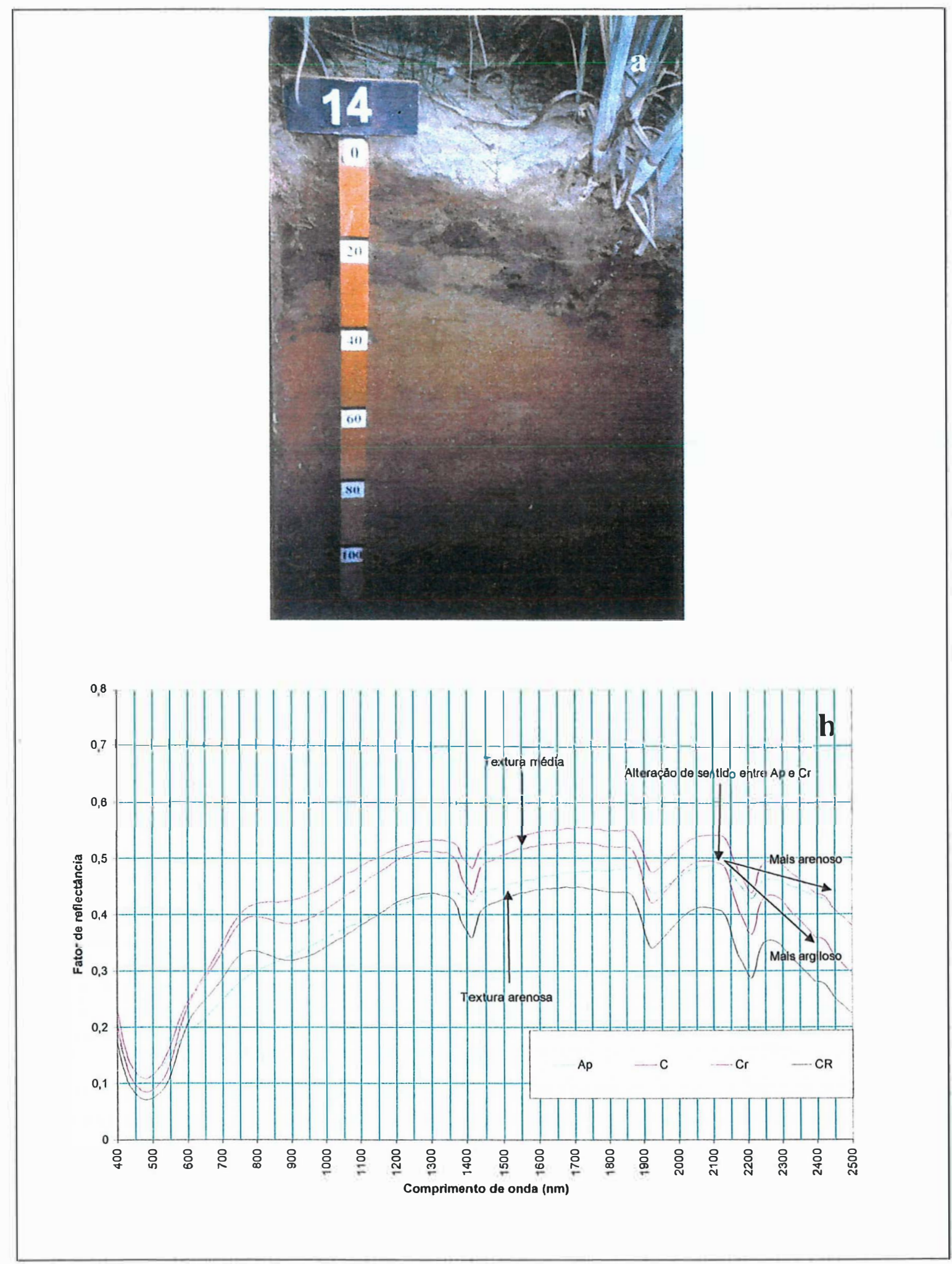

Figura 24 - Fotografia e curvas espectrais do Perfil 14 - NEOSSOLO REGOLÍTICO Distrófico Típico. 

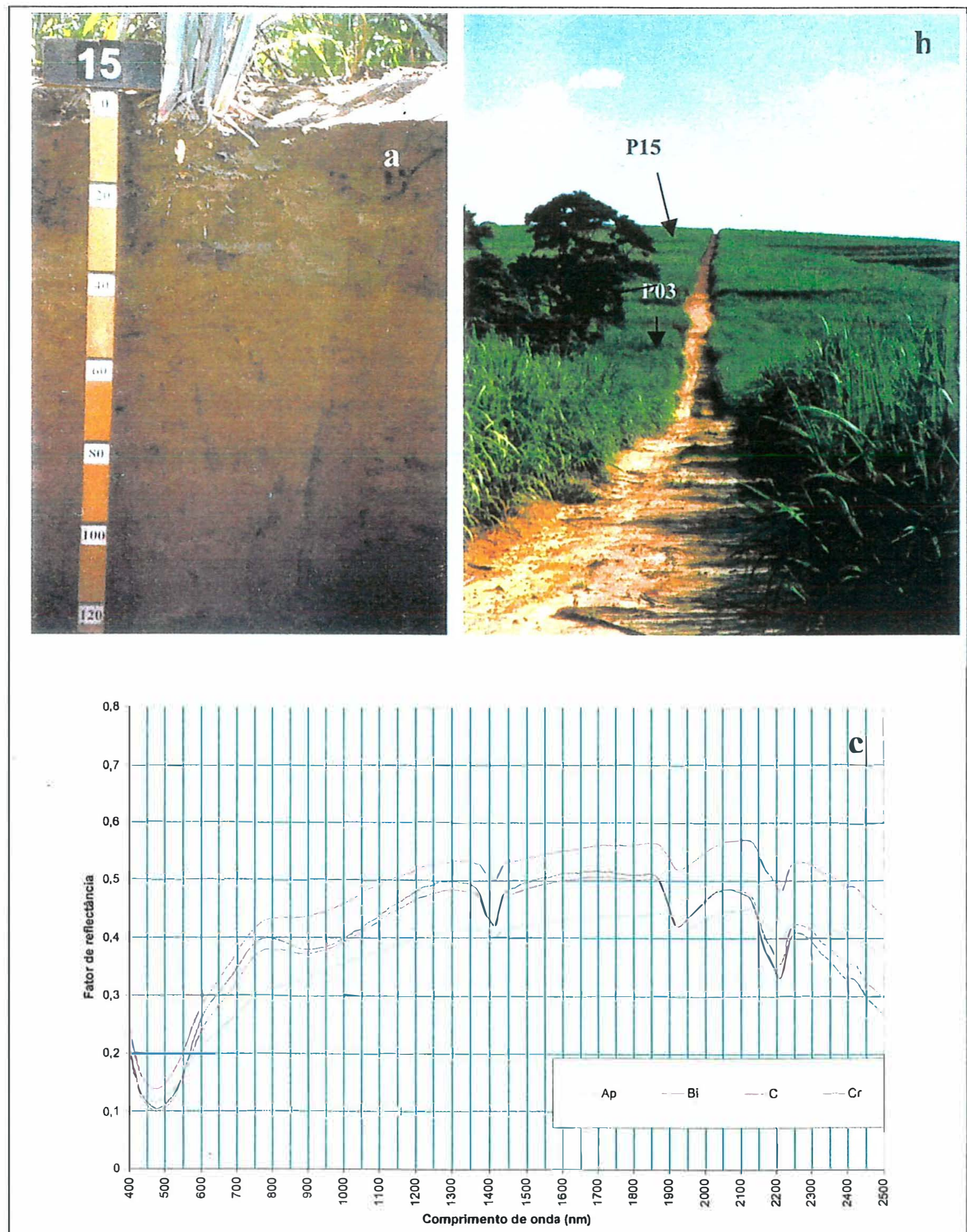

Figura 25 - Fotografia e curvas espectrais do Perfil 15 - CAMBISSOLO HÁPLICO Tb Distrófico típico. 

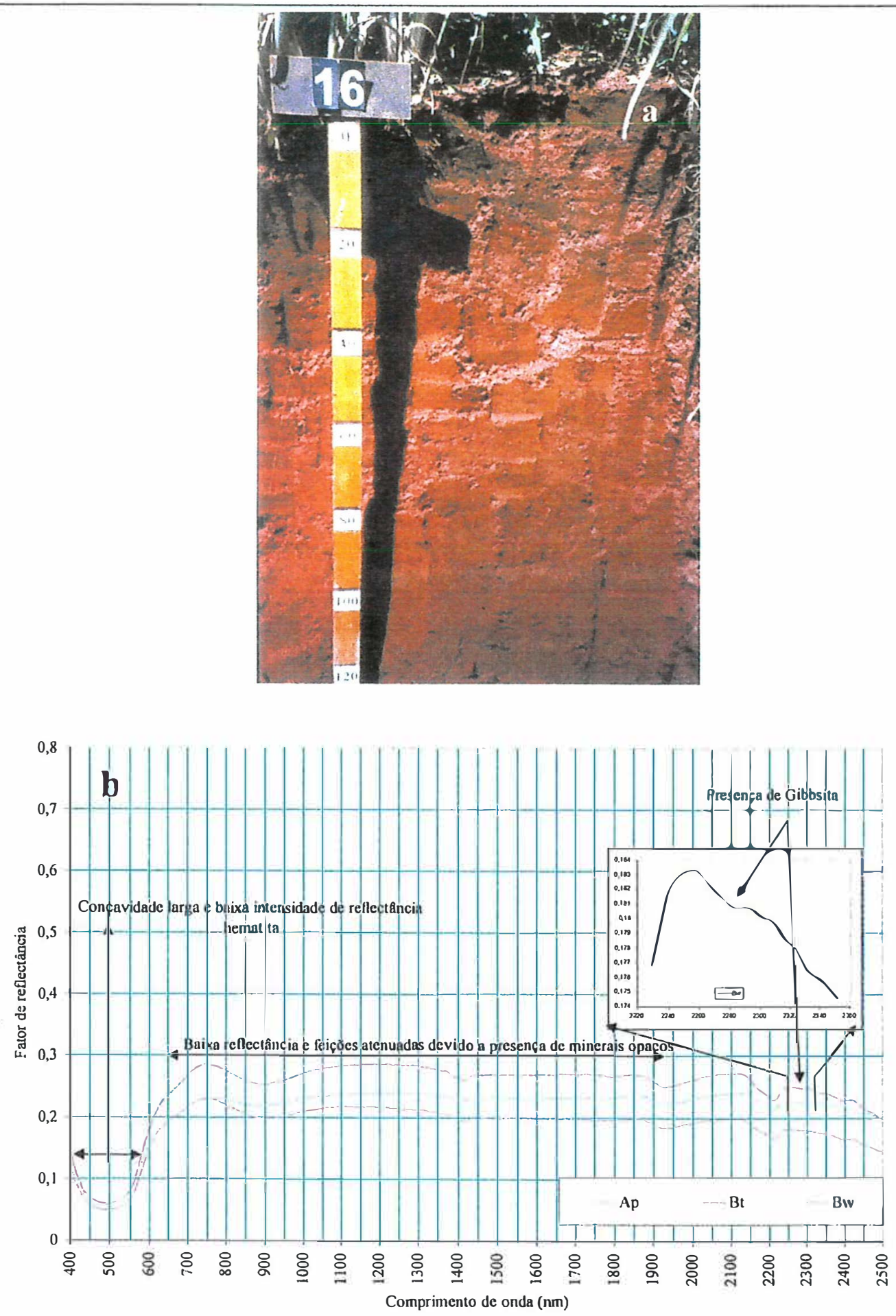

Figura 26 - Fotografia e curvas espectrais do Perfil 16 - NITOSSOLO VERMELHO Eutrófico Latossólico 

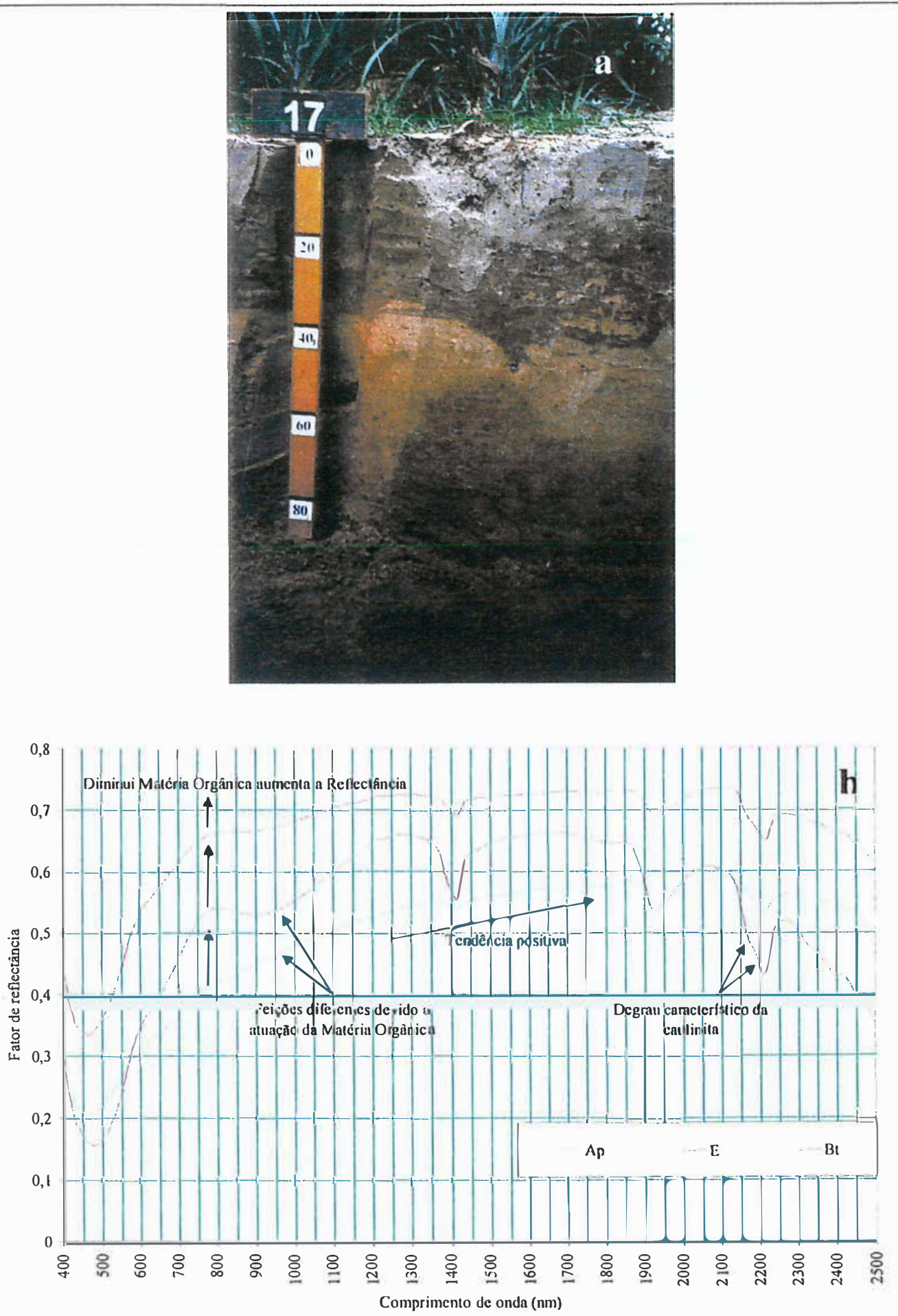

Figura 27 -Folografia e curvas especırais do Perfil 17 - ARGISSOLO AMARELO Eutrófico Abrúptico 
Tabela 3. Classificação das curvas espectrais (Ver Figuras 11 a 27) dos solos do presente trabalho, segundo Formaggio et al. (1996). Ver também Figura 2.

\begin{tabular}{|c|c|c|c|c|c|c|c|}
\hline $\begin{array}{l}\text { Hori- } \\
\text { zonte }\end{array}$ & $\begin{array}{l}\text { Classi- } \\
\text { ficação }\end{array}$ & $\begin{array}{l}\text { Hori- } \\
\text { zonte }\end{array}$ & $\begin{array}{l}\text { Classi- } \\
\text { ficação }\end{array}$ & $\begin{array}{l}\text { Hori- } \\
\text { zonte }\end{array}$ & $\begin{array}{l}\text { Classi- } \\
\text { ficação }\end{array}$ & $\begin{array}{l}\text { Hori- } \\
\text { zonte }\end{array}$ & $\begin{array}{l}\text { Class } \\
\text { icaçá }\end{array}$ \\
\hline \multicolumn{2}{|c|}{ Perfil 01} & \multicolumn{2}{|c|}{ Perfil 02} & \multicolumn{2}{|c|}{ Perfil 03} & \multicolumn{2}{|c|}{ Perfil 04} \\
\hline Ap & 2 & Ap & 2 & Ap & 2 & Alp & 1 \\
\hline$E$ & 2 & $\mathrm{Bi}$ & 4 & $\mathrm{Bi}$ & 2 & $\mathrm{~A} 2 \mathrm{p}$ & 1 \\
\hline Btg & 3 & $\mathrm{Crl}$ & 4 & $\mathrm{C}$ & 4 & Bti & 1 \\
\hline $\mathrm{C}$ & 2 & $\mathrm{Cr} 2$ & 4 & $\mathrm{Cr}$ & 4 & $\mathrm{Bt} 2$ & 1 \\
\hline $\mathrm{Cr}$ & 2 & $\mathrm{CR}$ & 2 & $\mathrm{R}$ & 4 & $\mathrm{Bw}$ & 1 \\
\hline
\end{tabular}

Perfil 05

$\begin{array}{cl}\mathrm{Ap} & 1 \\ \mathrm{Bi} & 1 \\ \mathrm{CB} & 1 \\ \mathrm{C} & 1\end{array}$

Perfil 09

$\begin{array}{cl}\text { Alp } & 2 \\ \text { A2p } & 2 \\ \text { C1 } & 4 \\ \text { C2 } & 4 \\ \text { Cr } & 4\end{array}$

\begin{tabular}{lr}
\multicolumn{2}{c}{ Perfil 13 } \\
Ap & 1 \\
BA & 1 \\
Bt1 & 1 \\
Bt2 & 1
\end{tabular}

\section{Perfil 06}

$\begin{array}{ll}\mathrm{Ap} & 1 \\ \mathrm{Bi} & 1 \\ \mathrm{Cr} & 4\end{array}$

Perfil 07

$\begin{array}{ll}\text { Ap } & 4 \\ \text { CR } & 4 \\ \text { R1 } & 4 \\ \text { R2 } & 4\end{array}$

\section{Perfil 08}

$\begin{array}{crr}\mathrm{Ap} & & 1 \\ \mathrm{Bi} & & 1 \\ \mathrm{C} & & 4 \\ \mathrm{Cr} & & 4 \\ & \mathrm{R} & 4\end{array}$

Perfil 12

$\begin{array}{cc}\mathrm{Ap} & 2 \\ \mathrm{AB} & 2 \\ \mathrm{Bt} & 3 \\ \mathrm{R} & 4 \\ \mathrm{Cr} & 4\end{array}$

\begin{tabular}{cr}
\multicolumn{2}{c}{ Perfil 15 } \\
$\mathrm{Ap}$ & 2 \\
$\mathrm{Bi}$ & 4 \\
$\mathrm{C}$ & 4 \\
$\mathrm{Cr}$ & 4
\end{tabular}

$\begin{array}{cr} & \text { Perfil 11 } \\ \mathrm{Ap} & 2 \\ \mathrm{Bi} & 2 \\ \mathrm{C} & 4 \\ \mathrm{Cg} & 4\end{array}$

$\begin{array}{lr} & \text { Perfil 14 } \\ \text { Ap } & 2 \\ \mathrm{Cl} & 4 \\ \mathrm{Cr} & 4 \\ \mathrm{R} & 4\end{array}$

$\begin{array}{cr} & \text { Perfil 10 } \\ \text { Ap } & 3 \\ \text { Bwl } & 4 \\ \text { Bw2 } & 4 \\ \text { BC } & 4\end{array}$

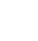

4

(1)

\section{Perfil 17}

$\begin{array}{cc}\text { Ap } & 2 \\ \text { E } & 4 \\ \text { Bt } & 4\end{array}$




\subsection{Relação entre atributos dos solos e sua influência na energia eletromagnética refletida}

A energia eletromagnética incidente numa amostra de terra, interage com todos as suas propriedades físicas e químicas, sendo que cada qual, age em um ou mais comprimentos de onda, mascarando ou não os efeitos de outros elementos, demonstrado pela refletância. Essas interações são a seguir discutidas, observando-se as curvas espectrais ilustradas nas Figuras 11 a 27 e Anexos A1 a A17.

O Perfil 1 (Figura 11), apresenta curvas espectrais típicas de solos com altos teores de areia (Anexo A1). Isto é observado pela alta intensidade de reflectância, na faixa de 0,6 . Isto ocorre pela presença de quartzo, mineral altamente refletivo (White et al., 1997). A concavidade fraca em $850 \mathrm{~nm}$ indica baixos teores de ferro (ratificado pelas análises). As cores claras aliadas aos baixos teores de ferro indicam a menor presença de óxidos de ferro como hematita, concordando com Costa (1979), o que provoca o não aparecimento da concavidade em $850 \mathrm{~nm}$. Os baixos teores de ferro promovem intensidades de reflectância mais elevadas, concordando com Donzelli (1984).

O Perfil 2 (Figura 12) apresenta as bandas de absorção devidas ás moléculas de água e grupos $\mathrm{OH}^{\circ}$ em $1400 \mathrm{~nm}$, bem como a banda da água em $1900 \mathrm{~nm}$ (Lindberg \& Snyder, 1972). A forte feição em $1900 \mathrm{~nm}$ indica presença de minerais do tipo 2:1, concordando com observações de Demattê et al. (1998a). Aliás, os altos valores de Ki indicam a mineralogia 2:1, conforme relatado por Sanchez (1981). Este perfil é de um solo jovem desenvolvido sobre arenitos estratificados. O comportamento das curvas espectrais é semelhante em todos os horizontes com fortes feições de absorção em 1400 
$\mathrm{nm}, 1900 \mathrm{~nm}$ e $2200 \mathrm{~nm}$, e fracas feições na faixa de 800 a $1050 \mathrm{~nm}$. A intensidade de reflectâcia é alta, atingindo o máximo ao redor de $73 \%$ para o horioznte $\mathrm{Cr} 1$. O horizonte A apresenta influência da matéria orgânica, consequentemente um albedo pouco menor e feições de absorção bem fracas. As curvas adequam-se ao padrão proposto por Valeriano et al. (1995) e Formaggio et al. (1996).

A avaliação das curvas espectrais do Perfil 3 (Figura 13) demonstram a existência do óxido de ferro goethita, pelas formas da curva em $700 \mathrm{~nm}$ e $850 \mathrm{~nm}$. Aliás, são solos com cores claras e amareladas, chegando a 9.1 YR. As bandas de absorção da goethita foram determinadas por Sherman \& Waite (1985). Este é o único perfil desenvolvido sobre folhelhos. O solum apresenta uma textura mais grosseira de natureza siltico-arenosa. As curvas padrão 2 (Tabela 3) apresentam feições de absorção mascaradas por efeito de matéria orgânica para amostras de Bi e Ap. O material menos intemperizado apresenta curvas com bandas de absorção intensas e padrão semelhante aos arenitos do perfil 12 e dos siltitos do Perfil 6. A intensidade de reflectância mais alta verificada para amostras de rocha (Máximo em torno de $75 \%$ ), seguem amostras dos horizontes $\mathrm{Cr}$ e C. Amostras do Bi apresentam uma intensidade de reflectância maior que $\mathrm{Cr}$ e $\mathrm{C}$ para comprimentos de onda maiores que $1870 \mathrm{~nm}$. Todas as amostras possuem cores amareladas comprovadas pelas carcaterísticas feições de absorção das goethitas (feições estreitas etre 450 e $600 \mathrm{~nm}$ ), ligeira concavidade entre 600 e $750 \mathrm{~nm}$.

Solos ricos em óxidos de ferro hematita apresentam uma concavidade mais larga entre 400 e 600 nm (Sherman \& Waite, 1985), bem como intensidade de reflectância mais baixa quando comparados com a goethita, concordando com Kosmas et al. (1984) e Bedidi \& Cervelle (1996). Isto pode ser observado no Perfil 4 de um Nitossolo (Figura 
14). Aliás, a concavidade é forte em $850 \mathrm{~nm}$ corroborando observações de Vitorello \& Galvão (1996) e Demattê et al. (2001). A presença de minerais 1:1 como a caulinita pode ser observada pela feição característica com um "degrau" em $2200 \mathrm{~nm}$ (Hauff et al., 1990; Kruse et al., 1991), ratificada por autores como Demattê \& Garcia (1999) e aqui verificada na curva do Nitossolo. A intensidade de reflectância aumentou com a profundidade de coleta, exceto para a amostra do horizonte $\mathrm{Bw}$, o mais profundo, cuja curva espectral aproximou-se das curvas das amostras do horizonte A. Feições de absorção amplas foram observadas ao redor de $900 \mathrm{~nm}$ e entre 450 e $550 \mathrm{~nm}$, a primeira pouco pronunciada em amostras do horizonte A. Essas curvas podem ser associadas à curva padrão "tipo l" proposta por Valeriano et al. (1995) e Formaggio et al. (1996) relacionada a solos derivados de rochas eruptivas básicas, geralmente muito argilosos, com elevados teores de ferro total ( $\left.>180 \mathrm{~g} \mathrm{~kg}^{-1} \mathrm{e}<400 \mathrm{~g} \mathrm{Kg}^{-1}\right), \mathrm{MnO}$ e $\mathrm{TiO}_{2}$ e altos teores de hematita, ilmenita, magnetita. Segundo Formaggio et al. (1996) as fortes bandas de absorção em comprimentos de onda menores que $550 \mathrm{~nm}$ deve-se à presença de $\mathrm{Fe}^{3+}$ em grandes quantidades, o mesmo é válido para a concavidade ao redor de $900 \mathrm{~nm}$ (Epiphanio et al., 1992), porém esta concavidade pode tornar-se apenas um leve decréscimo na inclinação da curva, devido à influência da matéria orgânica (Valeriano et al., 1995).

A interação de carbonatos com a energia eletromagnética refletida promove uma absorção em 2315 e 2400 nm, conforme observado na Figura 15 de um Chernossolo, Perfil 5, e concordando com Clark (1999). A própria concavidade estreita em $450 \mathrm{~nm}$ para a amostra do horizonte $\mathrm{C}$, indica a presença de goethita, aliás, tal horizonte apresentou-se bastante amarelado. Ao contrário, a amostra da camada mais superficial, 
avermelhada, apresentou concavidade mais larga devido à hematita, concordando com Clark (1999). As amostras de subsuperfície desse Perfil apresentam uma composição granulométrica com predomínio da fração areia (Anexo A5), entretanto, deve-se ressaltar que esta fração é composta por produtos do intemperismo inicial do diabásio, portanto, pobre em quartzo e não comparável com outras amostras de mesma textura provenientes de arenitos e normalmente ricas em quartzo.

O Chernossolo (Perfil 5) localiza-se em terço médio de encosta, em local com declividade aproximada de $17 \%$ (Anexo A5). Trata-se de solo jovem, com desenvolvimento incipiente e expõe no perfil os vários estágios de intemperismo de diabásios. São comuns a presença de matacões de diabásio na superfícíe e também dentro do solo. Está situado próximo ao Perfil 4 (Figura 7 e 8 ), porém submetido a diferentes condições de relevo e drenagem. Os horizontes superficiais apresentam cores avermelhadas contrastando com camadas rochosas em alteração onde predominam cores amarelas. Suas curvas espectrais apresentam as feições típicas de bandas amplas em torno de $450 \mathrm{~nm}$ e $900 \mathrm{~nm}$ comuns em solos derivados de rochas eruptivas básicas (Formaggio et al., 1996), ricos em óxidos de ferro, concordando com Formaggio (1983). Entretanto, a forma destas curvas difere da apresentada pelos Perfis 4 e 16. Elas assumem uma forma geral de arco e a intensidade de reflectância é em geral mais alta, aumentando conforme aumenta a profundidade de coleta das amostras. A inclinação das curvas na faixa de 1050 a 1350 nm é maior e na faixa de 1550 a 1900 assumem uma forma convexa com feições de absorção amplas próximas aos comprimentos de onda de 1420 e $1920 \mathrm{~nm}$ que tendem a aumentar com a profundidade de coleta, contrastando com a forma planar caracterísitca dos perfis 4 e 16. Entre os tipos padrões 
de curvas propostos por Valeriano et al. (1995) e Formaggio et al. (1996), as curvas deste perfil inicialmente foram enquadradas no tipo 1 (Tabela 3). Entretanto, são curvas com alta intensidade de reflectância, bandas de absorção forte e formato de arco (e não horizontal), não se enquadrando, portanto, em nenhum dos tipos de curva. Ou seja, quando se avalia detalhadamente o formato das curvas, muitas vezes não se enquadra nos tipos descritivos tradicionais. É o caso da curva espectral do Perfil 5, horizonte Bi. Tudo indica que poderízmos ter um outro tipo de curva, composto entre os tipos 1, 2 e 4 . Tal dificuldade em enquadrar curvas espectrais em tipos também foi verificada por Demattê (1995 e 1999), concordando com a presente discussão na necessidade de determinar novos tipos.

A ação dos óxidos de ferro podem ser observada na Figura 16 da camada superficial e subsuperficial de um Cambissolo Háplico Eutroférrico léptico. Observa-se que a concavidade em $850 \mathrm{~nm}$ se apresenta nas camadas superficial e subsuperficial, mesmo com as altas diferenças nos teores de matéria orgânica (de 22 para $10 \mathrm{~g} \mathrm{~kg}^{-1}$ respectivamente) que tendem a mascarar os efeitos dos óxidos. Ou seja, isto ocorreu por que os altos teores de ferro sobrepujaram os efeitos mascaradores da matéria orgânica. É interessante observar as diferenças provocadas pela hematita e goethita. $\mathrm{O}$ horizonte $\mathrm{Cr}$ apresenta cores mais avermelhadas ( 3 a 5 YR) do que a rocha (9.9 YR). Isto se reflete nas curvas espectrais, com formatos característicos da presença de hematita e goethita respectivamente (rever Figura 3). Verifica-se que as curvas do $\mathrm{Cr}$ e da rocha apresentam-se com altas intensidades de reflectância em relação às amostras de solo Ap e $\mathrm{Bi}$. Isto ocorre devido à presença de minerais primários, com maior ocorrência quando 
mais próximo ao material de origem. Tais minerais tendem a aumentar a intensidade de reflectância (Mathews et al., $1973 \mathrm{a}, \mathrm{b}$ ).

As curvas espectrais dos horizontes Ap e Bi do Perfil 6 (Figura 16) apresentamse semelhantes às descritas para os Perfis 4 e 16, levando a crer tratar-se de solos derivados de rochas básicas, com altos teores de $\mathrm{Fe}_{2} \mathrm{O}_{3}$ e $\mathrm{TiO}_{2}$ como comprovaram as análises realizadas (Anexo A6). Contudo, estes solos encontram-se sobre rochas sedimentares (siltitos de cor amarela) com curvas de intensidade alta. Esta configuração indica um perfil de solo com descontinuidade litológica em área de contato diabásiosiltito, com possível contribuição de material de origem coluvial oriundo do alto da encosta, onde ocorrem solos derivados do diabásio, além da mistura de materiais nos horizontes superficiais por práticas agrícolas. Os siltitos, conforme pôde-se constatar em campo, são rochas com baixíssima permeabilidade. Como resultado, nas áreas de contato siltito-diabásio, o fluxo lateral subterrâneo de água é interrompido ao encontrar a camada pouco permeável de siltitos. A água então aflora, e passa a correr em superfície. Estes afloramentos de água são comuns em locais próximos ao Perfil 6, principalmente após dias chuvosos.

O Neossolo Litólico (Perfil 17) apresenta ki compatível com presença mais elevada de minerais 2:1 (Figura 17). A feição em $1900 \mathrm{~nm}$ (forte) e em $2200 \mathrm{~nm}$, num formato retilíneo, indicam a presença dos minerais 2:1. Neste caso, pode-se comparar as curvas da Figura 3 dos minerais padrões obtidos por outros autores com as curvas deste solo para ratificar sua presença, concordando com observações preliminares de Demattê (1999). Este perfil está localizado no sopé da encosta, pouco abaixo do Perfil 6, tendo como material de origem os mesmos siltitos encontrados. Logicamente apresentam 
comportamento espectral semelhante, com intensidade de reflectância alta e feições de absorção associadas a goethita. As feições de absorção em torno de 1900 e 2200 são mais amplas que as observadas para o Perfil 6. O solo neste perfil restringe-se a uma camada de espessura máxima de $20 \mathrm{~cm}$ com grande quantidade de cascalhos.

A variação entre o comportamento espectral da camada superficial e da subsuperficial pode ser observada na Figura 18. A curva espectral da camada superficial não apresenta a concavidade em $850 \mathrm{~nm}$ devida aos óxidos de ferro, ao contrário da curva da camada subsuperficial, apesar de ambas apresentarem semelhantes teores de ferro (Anexo A8). Isto ocorre devido às diferenças nos teores de matéria orgânica, que cai de 29 para $15 / 10 \mathrm{gkg}^{-1}$ da camada superficial para as subsuperficiais. Ou seja, a matéria orgânica presente na camada superficial mascara os efeitos do ferro. Na segunda camada, mantêm-se os teores de ferro mas diminue o de matéria orgânica, sobressaindo a concavidade devida ao ferro, concordando com Coleman \& Montgomery (1987). Novamente observa-se variações significativas entre as amostras dos horizontes $\mathrm{Ap} / \mathrm{Bi}$ e $\mathrm{C} / \mathrm{Cr} / \mathrm{R}$, discutido anteriormente. A concavidade em $450 \mathrm{~nm}$ varia conforme a predominância de hematita ou goethita, conforme observado na Figura 18.

O Perfil 8 ocupa posição na paisagem semelhante ao Perfil 6 (Figuras 6 e 7). Os mesmos siltitos são encontrados sob o solum e o mesmo comportamento espectral é observado. Os horizontes superficiais apresentam curvas semelhantes a curva padrão "tipo 1" (Figura 18) (Valeriano et al., 1995; Formaggio et al., 1996). Apesar de serem solos mais amarelos e com menor teor de $\mathrm{Fe}_{2} \mathrm{O}_{3}$ não há diferenças observáveis em suas curvas em relação as outras de solos derivados do diabásio. Por estar localizado no terço 
inferior de encosta, é possível que haja alguma contribuição de material coluvial oriundo de posições superiores da encosta, onde ocorrem solos derivados do diabásio.

As curvas espectrais do Neossolo Regolítico são apresentadas na Figura 19, ocorrendo alta intensidade de reflectância, devido ao caráter arenoso.O Perfil 9 desenvolvido sobre arenitos com cimento argiloso apresenta um comportamento espectral diferenciado dos perfis analisados anteriormente. Há pouca diferença quanto a intensidade de reflectãncia entre as amostras analisadas até $1900 \mathrm{~nm}$, o fator máximo está em torno de $60 \%$ (Figura 19). A partir de $1900 \mathrm{~nm}$ pode-se distinguir um grupo formado pelas amostras do horizonte A com reflectância mais alta e as outras amostras, pertencentes ao horizonte C, com intensidades de reflectâncias mais baixas. A matéria orgânica mascara feições de absorção de óxidos de ferro na faixa de 800 a 1050 nm, fazendo as curvas de A assumirem um aspecto linear nesse intervalo. As feições de absorção dos óxidos de ferro na faixa de 450 a $600 \mathrm{~nm}$ imprimem tênues diferenças na intensidade de absorção, o que pode ter sido suficiente para diferenciar os subhorizontes no campo através de suas cores. Os horizontes mais profundos apresentam um fator de reflectância nesta faixa ligeiramente menor, o que está associado a maior proporção de hematita deixando o horizonte mais avermelhado quanto mais próximo da rocha. As curvas superficiais também seguem um padrão "tipo 2" de Valeriano et al (1995) e Formaggio et al (1996).

Outra diferença significativa entre a reflectância das camadas superficiais e subsuperficiais, refere-se a sua intensidade. A camada superficial, por apresentar maior teor de matéria orgânica, que absorve energia (Henderson et al., 1992), promove 
intensidade mais baixa (Figura 20). Com a diminuição no teor de matéria orgânica nas camadas subsuperficiais, a intensidade de reflectância aumenta.

As curvas espectrais observadas na Figura 21 mostram diferenças na tendência (angularidade) das curvas espectrais. Para visualizar este fato é necessário observar a curva por inteira dos 400 aos $2500 \mathrm{~nm}$. Veja que a curva espectral da camada superficial inicia com intensidade de reflectância mais baixa e vai aumentando gradativamente, promovendo uma forma ascendente de curva. A curva do horizonte $\mathrm{Cg}$ por sua vez, inicia em intensidade mais elevada que o Ap e a forma da curva se mantêm numa tendência constante e horizontal. Tais variações de angularidade da forma foi observada por Demattê et al. (2000) e aqui se ratifica. A explicação está ligada composição granulométrica. A camada A é mais arenosa e a subsuperficial mais argilosa. A presença de quartzo na camada superficial aumenta a intensidade de reflectância (White et al., 1997). Ou seja, solos mais arenosos tendem a apresentar o aspecto de tendência positiva ao contrário dos mais argilosos. Tais resultados concordam com Al-Abbas et al. (1972), Montgomery (1974) e Boluda et al (1990) que observaram que solos argilosos refletem menos que os arenosos. Essa mesma tendência é ratificada observando-se as curvas do Perfil 13 (Figura 23).

As curvas espectrais das camadas superficial (A e AB) e a subsuperficial (Bt), apresentam formas descritivas distintas (Figura 22) no Perfil 12. As duas primeiras apresentam um formato convexo em $950 \mathrm{~nm}$ e a oura côncava. Tais características estão intimamente ligadas à atuação da matéria orgânica e óxidos de ferro presentes no material. 
Os dados espectrais do Argissolo Vermelho (Figura 23), por sua vez, apresentam a ligeira concavidade em todas as amostras, sendo mais acentuada na subsuperficial. Além disso, a concavidade mais larga em 450/500 nm (Sherman \& Waite, 1985) e baixa reflectância (Kosmas et al., 1984), indicam a predominância de hematita. Esse perfil, bem estruturado com gradiente textural alto, apresenta curvas espectrais com tendência horizontal, tipo 1, com feições de absorção fracas nos horizontes $A p$ e $A B$ e baixa reflectância ao longo de todo o espectro. As feições de absorção soa pouco mais forte para os horiozntes B texturais. Concavidade larga na faixa de 450 a $600 \mathrm{~nm}$ evidenciando a presença de hematita. Os metais de transição como o Fe dominam as feições espectrais entre 400 e $100 \mathrm{~nm}$ (Gupta, 1991), ratificando as amplas bandas de absorção pelas hematitas nesta faixa, concordando com Vitorello \& Galvão, 1996). Solo desenvolvidos sobre diabásio em terçco infeior de encosta, com expressiva eluvação de argilas e possível contribuição de material mais arenoso em superfície.

Curvas do padrão "tipo 2" foram também observadas no Perfil 12, amostras de superficie (Figura 22). O perfil desenvolvido sobre arenito estratificado de granulometria, apresentado camadas mais resistentes e outras camadas menos resitentes ao intemperismo. Uma camada mais resistente $(\mathrm{R})$ pouco afetada pelo inteperismo é encontrada entre o horizonte $\mathrm{Bt}$ e um estrato de rocha mais alterado (camada $\mathrm{Cr}$ ). Amostras dessa camada apresentam o mais alta intensidade de reflectância (máximo em torno de $70 \%$ ), cores amareladas e uma configuração de curva semelhante a observada para os siltitos do perfil 6. A curva de $\mathrm{Cr}$ apresenta também o mesmo tipo de forma, porém é retitínea entre 600 e $750 \mathrm{~nm}$, enquanto $\mathrm{R}$ apresentas uma ligeira concavidade na mesma faixa, normalmente atribuída aos maiores teores de goetita, que apresenta 
feição de absorção mais pronunciada nest faixa do que a hematita. Os mais baixos albedos são verificados para o horizonte Bt cujas análises químicas demonstram os maiores teores de matéria orgânica, entretanto, este parece não mascarar as feições de absorção deste horizonte. Mesmo com menores teores de matéria orgânica, as amostras do horizonte A, principalmente A1 mostraram um mascaramento de feições em todo o espectro.

O importante na interpretação das curvas espectrais, é a análise descritiva, concomitantemente das curvas das amostras superficiais e subsuperficiais. Vale lembrar, que da mesma forma é realizado na interpretação de análises de solo pelos métodos tradicionais. Faz-se interpretações de análises entre as diferentes profundidades procurando verificar diferenças. Observando as curvas espectrais do Perfil 14 (Figura 24), verifica-se que a curva da camada superficial apresenta caráter arenoso $\left(120 \mathrm{~g} \mathrm{~kg}^{-1}\right)$. A curva do $C$ por sua vez, chega a textura média $\left(220 \mathrm{~g} \mathrm{~kg}^{-1}\right)$, e alterações na curva espectral. Ou seja, a variação observada quantitativamente nos dados analíticos dos solos, pôde ser detectada nos aspectos descritivos da curva espectral.

O Perfil 15, um Cambissolo Háplico Tb (Figura 25) também apresenta variações no comportamento espectral entre as amostras dos diferentes horizontes, concordando com observações de Galvão et al. (1997).

A banda de absorção observada em 2265/2285 nm nas curvas espectrais do Perfil 16, Nitossolo Vermelho (Figura 26) indica a presença de gibbsita, concordando com Madeira Netto et al. (1996). Apesar de tênue, tal banda ocorre devido à presença deste óxido de alumínio. É importante destacar, que mesmo sendo um solo com baixa intensidade de reflectância que absorvem energia e tendem a mascarar os efeitos de 
outros elementos, esta banda se apresentou. A presença deste óxido de alumínio promove principalmente esta banda de absorção, observação ratificada por Demattê \& Garcia (1999), em Latossolos porém.

O Perfil 16 apresenta curvas espectrais semelhantes ao Perfil 4 com ligeira queda no fator de reflectância. Seus atributos fĩsicos, químicos e morfológicos também são semelhantes ao Perfil 4. As análises químicas e físicas de ambos perfis revelam concordância com os atributos descritos por Formaggio et al. (1996) para as curvas "tipo 1". Uma particularidade desses perfis é o comportamento das curvas espectrais dos horizontes mais profundo de ambos, um B latossólico (Bw), que apresentam intensidades de reflectância próximas e até menores que os horizontes superficiais de seus respectivos perfis. A menor reflectância em horizontes superficias é atribuída a matéria orgânica, entretanto, isto não pode explicar a reflectância menor de Bw. Formaggio et al (1996) destacam que geralmente latossolos roxos (solos com $\mathrm{Bw}$ ) apresentam menor albedo que terras roxas estruturadas (solos com Bt) e atribuem o fato a uma possível granulometria mais arenosa devida aos materias de origem dos últimos; entretanto, referem-se a horizontes de perfis distintos e não horizontes gerados em mesmo perfil como o presente caso.

A Figura 27 ilustra várias situações concomitantemente. Ela representa o comportamento básico das curvas espectrais dos solos ao longo do perfil. Comparandose as curvas do horizonte Ap com os demais, sua tendência é positiva e a dos outros horizontal, concordando com observações anteriores sobre a textura dos horizontes. O horizonte A é mais arenoso e os outros mais argilosos (Anexo A17), promovendo uma tendência positiva, concordando com Demattê et al. (2000). A curva espectral do 
horizonte Ap não apresenta concavidade em $850 \mathrm{~nm}$, ao contrário dos outros, devido ao mascaramento pela matéria orgânica (Cipra et al., 1972), que absorve energia (Baumgardner et al., 1972). A intensidade de reflectância da curva espectral da camada superficial é menor que os demais na maior parte do espectro eletromagnético, devido à absorção de energia pela matéria orgânica (Henderson et al., 1992). A banda em 2200 nm apresenta o degrau característico e feição da caulinita, portanto, indicando sua presença, concordando com Hauff et al. (1990). O fato das bandas de absorção serem fortes em 1400, 1900 e $2200 \mathrm{~nm}$ indica a presença, apesar de pequena, de minerais 2:1, concordando com Demattê et al. (1998 a). Sua quantificação, entretanto, demandaria a existência de modelos de quantificação de assimetria das bandas, como realizado por Demattê (1999).

O Perfil 17 (Figura 27) também derivado de arenito apresenta um horizonte E com cores claras e fração areia com altos teores de quartzo. Apresenta as mais altas intensidades de reflectância entre todas as curvas observadas com a máxima verificada em torno de $73 \%$. O padrão espectral está proximo ao "tipo 4" (camada subsuperficial) proposto por Valeriano et al. (1995) e Formaggio et al. (1996). Este padrão é semelhante ao "tipo l", com influência de óxidos de ferro, porém em teores relativamente baixos (5 a $6 \mathrm{~g} \mathrm{~kg}^{-1}$ ), manifestando uma banda de absorção centrada em $850 \mathrm{~nm} \mathrm{e}$ influenciando a primeira pare da curva espectral (até $1000 \mathrm{~nm}$ ). O restante da curva seria parecido com a curva do padrão "tipo 2". Valeriano et al. (1995) incluíram as Areias Quartzosas como solos que seguem o padrão "tipo 4", estes solos com mineralogia predominante formada por quartzo estaria bem próximo dos atributos verificados para horizontes $\mathrm{E}$. O horizonte $\mathrm{Bt}$ do mesmo perfil parece adequar-se ao 
mesmo padrão, embora menos arenoso, com feições de absorção mais pronunciadas e intensidade de reflectância menor. O horizonte superficial, também arenoso, com fator de reflectância máxima em torno de 59 \% tem suas feições mascaradas pela matéria orgânica e padrão tipo 2.

As Figuras 28, 29 e 30 ilustram o comportamento espectral detalhado atributos dos solos como a matéria orgânica e óxidos de ferro, permitindo a melhor visualização dos seus efeitos, sendo a seguir discutidas.

A matéria orgânica, conforme relatado em literatura, absorve energia eletromagnética (Baumgardner et al., 1972). Um exemplo de curva espectral de material orgânico é apresentado na Figura 28a , tendo sido extraída do trabalho de Demattê (1999). Observa-se uma curva espectral com intensidade de reflectância extremamente baixa, sem feições com aspecto retilíneo. Na medida em que um material com estas características é introduzido no "material" solo, este tende a tomar seu aspecto. Isto explica as observações anteriores das baixas intensidades de reflectância das amostras dos horizontes com maiores teores de matéria orgânica, concordando com Baumgardner et al. (1972) e Baumgardner et al. (1985). Do mesmo modo, tal curva auxilia na visualização do seu efeito mascarador na concavidade dos óxidos de ferro em $850 \mathrm{~nm}$. A Figura 28b ratifica tais observações e concorda com Courault \& Girard (1988). Na medida em que ocorre um aumento no teor de matéria orgânica, ocorre uma diminuição na intensidade de reflectância.

A variação da granulometria dos solos, conforme verificado em discussão anterior, influencia os aspectos descritivos dos dados espectrais. No caso os solos mais arenosos geralmente refletem mais que os argilosos, concordando com Al-Abbas et al. 
(1970) e Boluda et al. (1990). Além disso, os solos arenosos e os argilosos apresentarem um formato ascendente e horizontal respectivamente (Figura 29), concordando com Demattê et al. (2000). Aliás, as relações entre teor e forma verificadas, vem reforçar a possibilidade de quantificação dos teores de argila, conforme verificado por Coleman et al. (1991), Demattê \& Garcia (1999) e Nanni (2000), por meio de modelos matemáticos.

Os efeitos dos óxidos também podem ser detectados pelos aspectos descritivos dos dados espectrais. Os solos com cores mais amareladas apresentam curvas espectrais semelhantes à goethita, enquanto que amostras mais avermelhadas, com predominância de hematita (Schwertman \& Taylor, 1977), têm comportamento distinto. Aliás, essa variação na cor, relativa aos óxidos, pode ser observada nas curvas de amostras distintas (Figura 30). Pode-se relacionar os aspectos descritivos das amostras de terra ilustrados na Figura 30a com as Figuras dos respectivos óxidos (Figura 3).

A Figura 29 relaciona o ki dos solos com os aspectos espectrais descritivos. Solos com ki mais elevados apresentam mineralogia com predominância do tipo 2:1, sendo solos geralmente menos intemperizados, enquanto que ki mais baixos mineralogia caulinítica ou até oxídica, no caso de solos mais intemperizados (Sanchez, 1981). Como observado anteriormente, as bandas em 1900 (principalmente) e $2200 \mathrm{~nm}$ indicam a presença de minerais 2:1 e 1:1 dependendo de seus aspectos descritivos. No caso, observa-se que na medida em que o ki aumenta, a banda em $1900 \mathrm{~nm}$ fica mais acentuada, justamente devido aos minerais $2: 1$, conforme verificado por Grove et al. (1990). Solos mais intemperizados com ki de valor mais baixo indicam solos mais oxídicos e bandas menos acentuadas. 

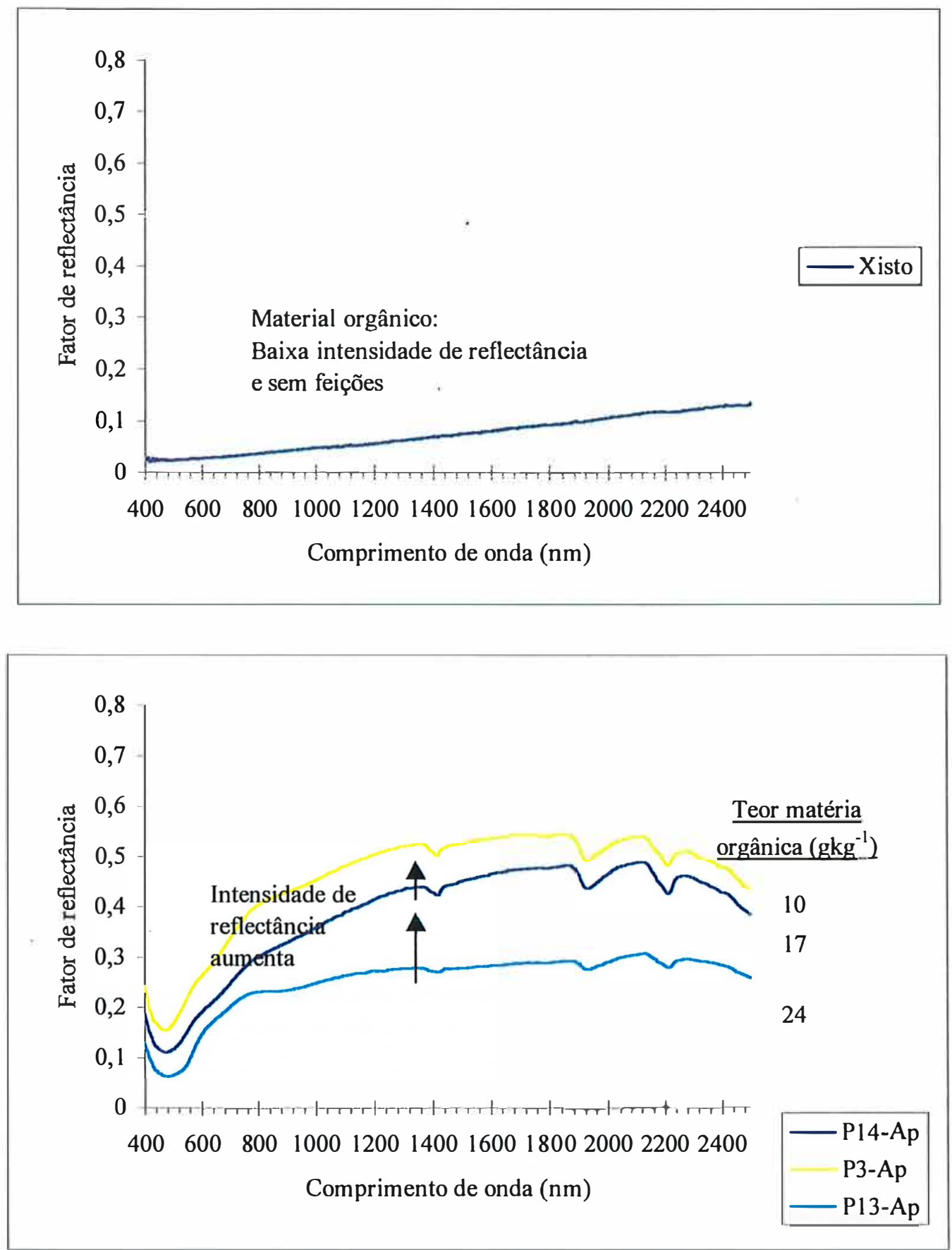

Figura 28. a) Curva espectral de uma material orgânico denominado xisto retortado. Curva espectral extraída de Demattê (1999); b) Curvas espectrais de amostras de terra com diferentes teores de argila. São indicados o número dos perfis e respectivos horizontes. 

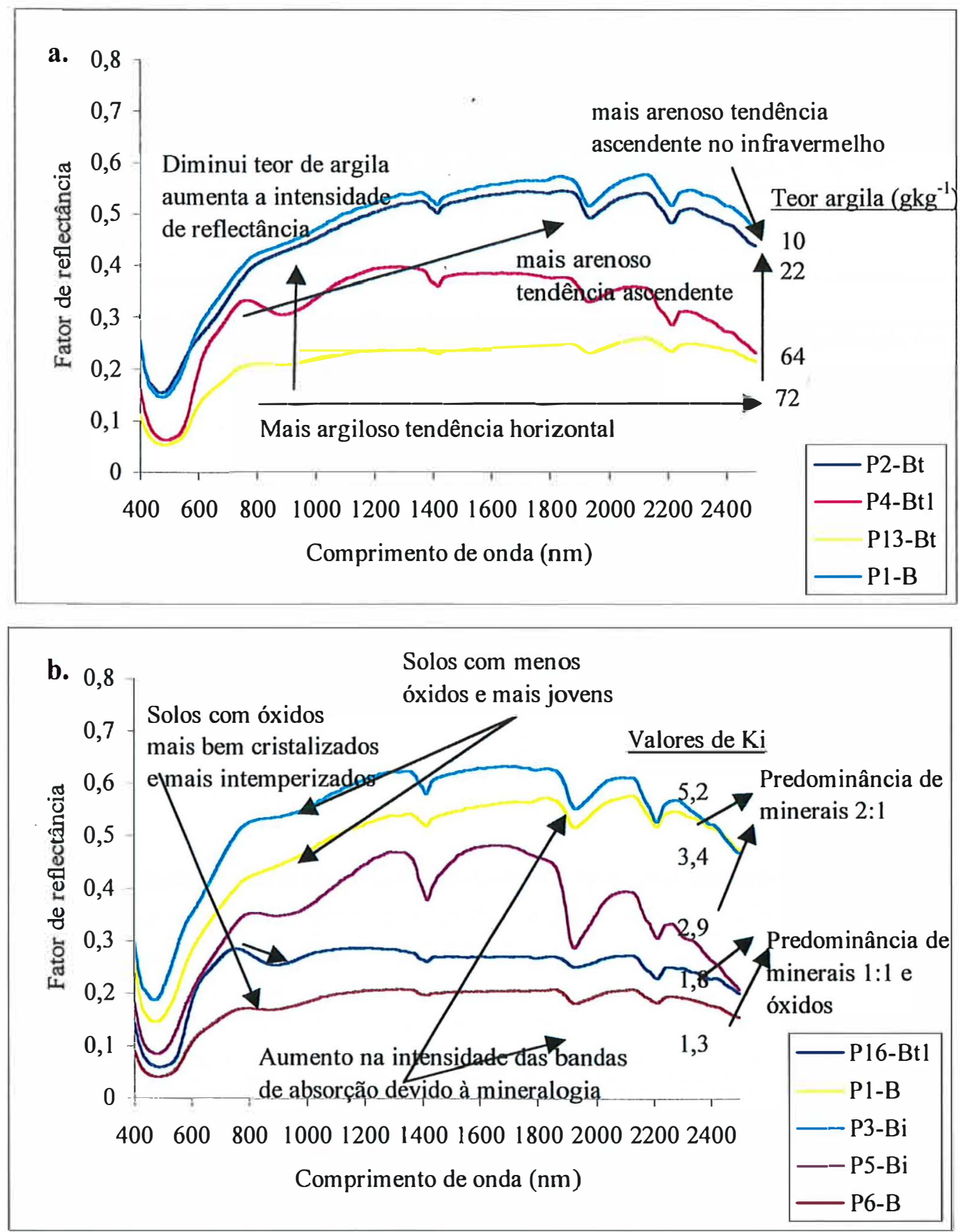

Figura 29. a) Curvas espectrais de alguns perfis relacionados aos teores de argila; b) Curvas espectrais de alguns perfis relacionados aos valores de ki. 


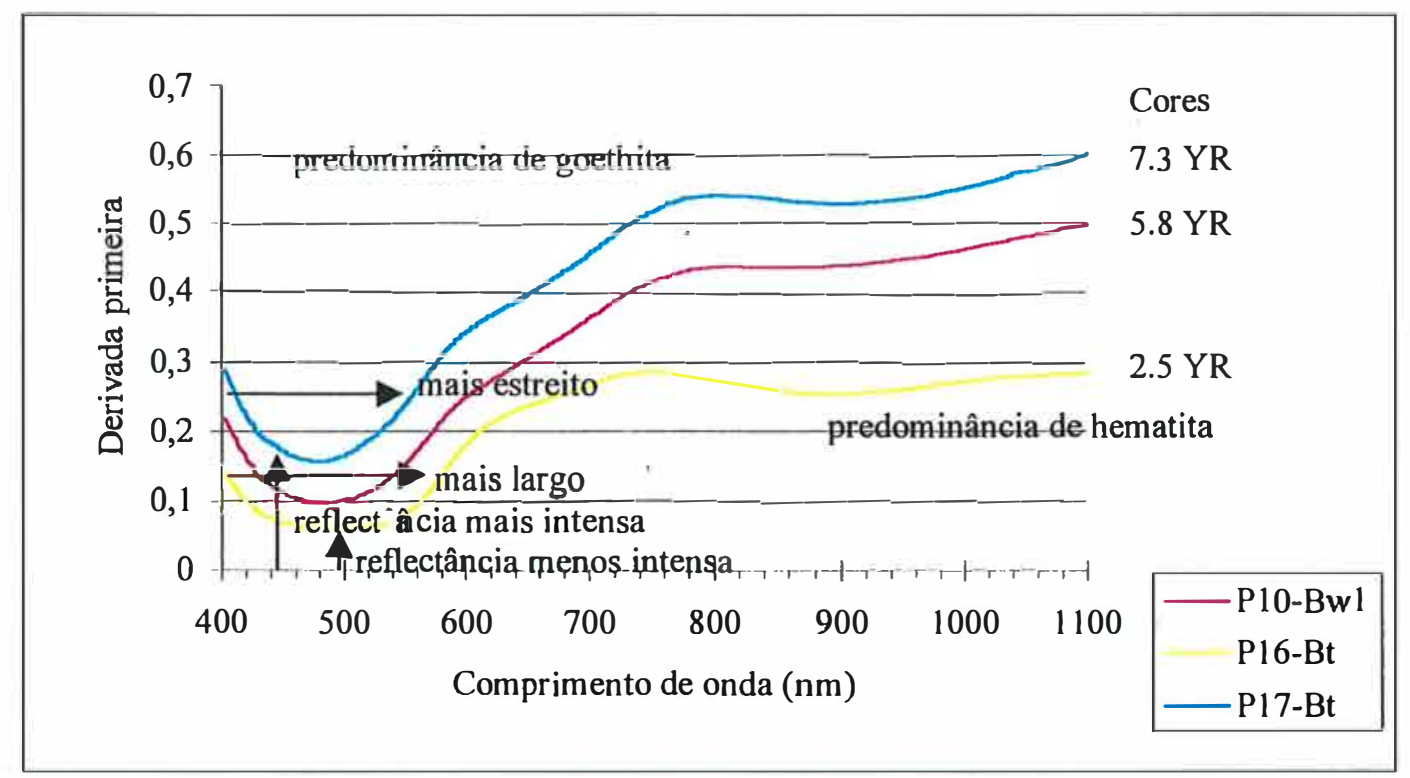

Figura 30. a) Curvas espectrais dos perfis 10, 16 e 17 relacionados às cores e óxidos. 


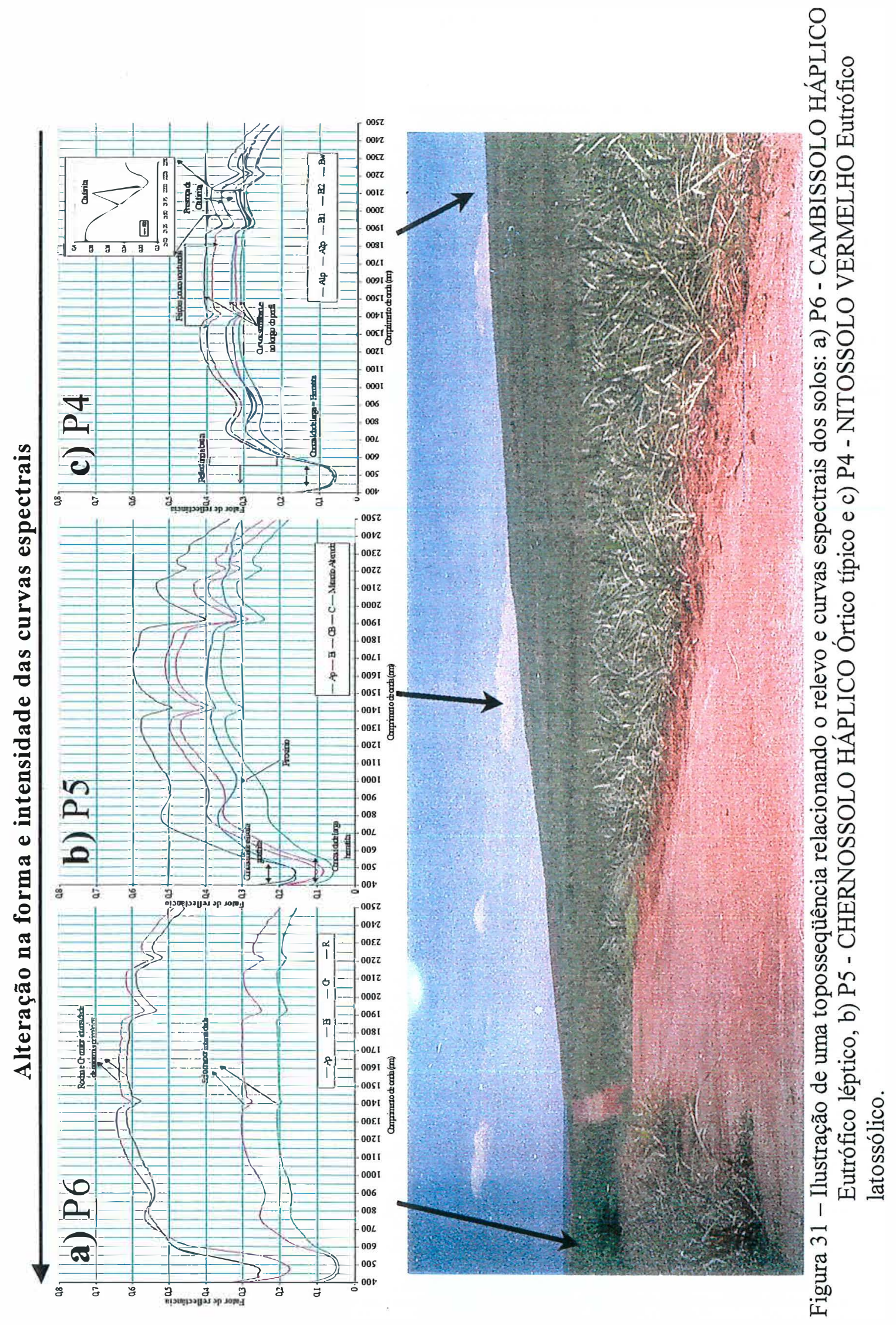


Em relação às camadas de alteração, amostras destas foram retiradas de um matacão de diabásio com esfoliação concêntrica do perfil 5. A curva espectral desta amostra mostrou uma intensidade de reflectância baixa e uma forma diferente das amostras de solo retiradas de local próximo. As feições de absorção em 1420, 2200 e $2300 \mathrm{~nm}$, comuns em solos, são praticamente nulas devido ao mascaramento pelos minerais opacos como a magnetita (Hunt et al., 1972). A feição relacionada a $1920 \mathrm{~nm}$ é muito fraca. A curva apresenta uma feição bastante larga e pouco profunda centrada em $1000 \mathrm{~nm}$, relacionada a banda de absorção do piroxênio, mineral constituinte dos diabásios, cujas feições mais proeminentes ocorrem variando de 900 a $1050 \mathrm{~nm}$ (Vitorello \& Galvão, 1996). Feições próximas a 1000 e 1900 nm também foram observadas por Demattê et al. (1999) em amostras de diabásio inalterados e alterados da região de Piracicaba.

A curva de rocha do perfil 6 ou 7 (cor 0.3 Y6.6/3.5) apresenta uma configuração muito próxima da goethita pura para comprimentos de onda inferiores a $1200 \mathrm{~nm}$ (Figura 3) indicando praticamente ausência de hematita. A rocha intemperizada $(\mathrm{Cr})$ apresenta indícios da presença de hematita, com uma absorção mais pronunciada em $445 \mathrm{~nm}$ e uma concavidade mais larga entre 400 e $600 \mathrm{~nm}$. O padrão de intemperismo dessas rochas verificado em campo, consiste num avermelhamento das superfícies das rochas que vai se aprofundando para o interior das mesmas, conforme aumenta o grau de intemperismo, o que justificaria o aumento de hematita em rochas mais intemperizadas. Comparando as feições de absorção das curvas das amostras deste perfil na faixa de 500 a $650 \mathrm{~nm}$, observa-se que amostras mais vermelhas, normalmente 
associadas a teores maiores de hematita apresentam pontos de inflexão (mudança do sinal de curvatura) mais altos, o que gera feições côncavas mais largas nesta faixa.

O padrão "tipo 2" de curva espectral, definido por Valeriano et al. (1995) e Formaggio et al. (1996), está associado a solos que apresentam nos horizontes superficiais, predominância de texturas arenosas e médias e baixos teores de matéria orgânica e de óxidos de ferro e titânio. São muitas vezes provenientes de sedimentos arenosos e areno-argilosos oriundos do retrabalhamento de arenito, podendo ser, ainda, ocasionalmente derivados de argilitos e siltitos (Formaggio et al., 1996). Alguns perfis estudados são desenvolvidos sob arenitos com cimento argiloso, portanto, espera-se comportamento espectral semelhante à curva padrão "tipo 2". Tal comportamento foi observado nas amostras dos Perfis 14, 15, 10 e 11 (Figuras 24, 25, 20 e 21), todos solos desenvolvidos sob materiais semelhantes com pequenas variações de textura e grau de desenvolvimento dos perfis. A intensidade de reflectância máxima desses perfis é verificada em torno de 5 5\% sempre para os horizontes B dentro da faixa de 1550 a 1900 nm. Os horizontes superficiais apresentam normalmente as mais baixas reflectâncias e feições de absorção fracas devido a presença de matéria orgânica. A concavidade entre 850 e $1050 \mathrm{~nm}$ normalmente associadas a feições de absorção dos óxidos de ferro desaparecem nesses horizontes. As amostras de rochas ou horizontes $\mathrm{C}$ apresentam normalmente reflectâncias intermediárias entre o horizonte $\mathrm{B}$ e $\mathrm{o} \mathrm{A}$, as vezes até menor que o A em alguma faixa do espectro. As amostras de $B$, porém, mostram feições de absorção fortes, inclusive nas bandas de absorção dos óxidos de ferro. $\mathrm{O}$ comportamento das curvas entre 600 e $750 \mathrm{~nm}$ é linear ascendente com ligeiras concavidades em amostras do perfil 11, o de cor mais amarela deles. A largura das 
feições de absorção entre 450 e $600 \mathrm{~nm}$ mostram-se relacionadas aos matizes das cores das amostras, quanto mais vermelho o solo, maior a razão conteúdo de hematita/conteúdo de goetita e maior é a largura da concavidade nesta faixa do espectro, relacionada a absorção provocada pelos íons $\mathrm{Fe}^{3+}$ presentes nestes minerais.

\subsection{Comportamento espectral dos solos ao longo da paisagem e sua relação com a classificação}

A avaliação espectral dos solos ao longo de uma paisagem pode auxiliar na determinação de limites de solos e consequentemente no seu mapeamento. De acordo com este raciocínio, foram escolhidas três classes de solos de ocorrência na paisagem da área de estudo, sendo: Perfil 4 representado por um Nitossolo Vermelho eutrófico; Perfil 5 representado pelo Chernossolo Háplico e Perfil 6, Cambissolo Háplico, cujos dados analíticos já foram discutidos anteriormente (Anexos A4, A5 e A6). As curvas espectrais de tais solos, assim como sua posição na paisagem estão indicadas na Figura 31.

O Perfil do Nitossolo ocupa a posição mais alta da paisagem e tem como características marcantes o elevado teor de óxidos de ferro, a textura argilosa a muito argilosa, a boa drenagem, o caráter eutrófico e uma mineralogia representada pela caulinita e óxidos de ferro e alumínio. Nas curvas espectrais observa-se a ampla concavidade representada pelo ferro, assim como as demais bandas correspondentes aos minerais de argila, no caso a de pequena intensidade para os minerais $2: 1$ e as de maior intensidade para a caulinita (Figura 31). Tais solos apresentam curvas espectrais 
homogêneas das amostras em profundidade o que de fato ocorre na própria avaliação de campo. Aliás, Demattê (1995 e 1999) verificou que tais solos apresentam curvas homogêneas das amostras dos horizontes em relação aos aspectos descritivos. A tendência das curvas deste perfil é a mesma em profundidade reduzindo, entretanto, a intensidade de reflectância mas mantendo as mesmas bandas de absorção.

Por sua vez, o solo Chernossolo, por apresentar Ki mais elevado, na faixa de 2,9 apresenta grande contribuição de minerais 2:1 e apresenta textura diferenciada em profundidade, promovendo curvas espectrais totalmente distintas entre horizontes e bem diferentes quanto às intensidades e formas quando comparadas com o Nitossolo (Figura 21). Note a forte intensidade das bandas de absorção correspondentes aos minerais $2: 1$, conferindo-lhe características de solo menos intemperizado.

O mesmo se pode dizer das curvas espectrais do perfil do Cambissolo Háplico, totalmente distintas dos demais solos desta paisagem. Ou seja, a interpretação das curvas espectrais das amostras superficiais e subsuperficiais, permitiu discriminar os solos ao longo da paisagem, bem como inferir características analíticas qualitativas, que auxiliassem neste objetivo. Aliás, Stoner \& Baumgardner (1980) determinaram um Atlas de curvas espectrais de perfis de solos, devidamente classificados pela classificação americana, permitindo detectar uma relação preliminar entre classificação do solo de um perfil com as informações espectrais. No presente trabalho, as curvas espectrais de superfície e de subsuperficie, em discriminando os solos, permitiu relacioná-los com a respectiva classificação realizada no campo. Neste caso, os dados espectrais podem auxiliar na classificação preliminar dos solos concordando com Epiphanio et al. (1992). 
Pelos métodos tradicionais de avaliação do intemperismo, a literatura já demonstra a variabilidade das características dos solos ao longo da paisagem pelos estudos de gênese, como realizado por Demattê \& Marconi (1991). No presente trabalho, como tais características influenciaram diferenciadamente os dados espectrais, verifica-se uma relação entre dados dos solos na paisagem e dados espectrais dos solos. Estes fatos indicam que os solos são discrimináveis pelas curvas espectrais vindo corroborar os resultados obtidos por outros autores tais como Coleman et al. (1991). Da mesma forma, o fato das curvas espectrais dos solos apresentarem-se diferentes ao longo da paisagem, como verificado na Figura 21, ratifica observações anteriores de Demattê et al. (1998b). Tais resultados vêm demonstrar ser possível discriminar e avaliar os níveis de intemperismo dos solos ao longo de uma paisagem pela análise das curvas espectrais, concordando com Demattê \& Garcia (1999), auxiliando em mapeamento de solos, como verificado por Demattê et al. (2001). Aliás, os resultados corroboram observações de Demattê (1999), para o qual cada classe de solo apresenta uma assinatura espectral característica, e que cuja variabilidade pode ser detectada quando utilizando-se de modelos matemáticos. 


\section{CONCLUSÕES}

Cada classe de solo apresentou características de classificação distintas, devido aos dados analíticos e morfológicos, que por sua vez apresentaram íntima relação com os dados espectrais descritivos, discriminando as classes de solos.

A análise descritiva observada na literatura pelos Tipos de curva, enquadraram os solos arenosos principalmente nos Tipos 2 e 4, e os solos com maior contribuição do diabásio no Tipo 1. Numa análise mais detalhada das curvas espectrais (Forma, feições e intensidades de absorção), porém, pode-se obter maiores informações sobre uma amostra de terra, do que as análises de Tipo.

Os solos arenosos refletiram mais, com curvas espectrais de aspecto ascendente, ao contrário do solos argilosos. A banda em $1900 \mathrm{~nm}$, discriminou solos com mineralogia 2:1 dos oxídicos e 1:1. Foi possível detectar a presença de caulinita, gibbsita, óxidos de ferro hematita e goethita presente nos solos, pelos aspectos descritivos das curvas, feições de absorção e intensidade de reflectância, bem como a influência da granulometria e matéria orgânica.

Solos desenvolvidos de arenito apresentaram intensidades de reflectância mais elevadas do que os solos de diabásio. A avaliação dos dados espectrais de amostras dos 
horizontes superficiais e subsuperficiais permitiu discriminar a variabilidade analítica do perfil, auxiliando na discriminação dos solos e sua classificação.

Existe relação entre os níveis de intemperismo dos solos e as informações espectrais. Os resultados indicam que as informações espectrais podem ser utilizadas como auxílio na caracterização, discriminação e classificação dos solos. 


\section{CONSIDERAÇÕES FINAIS}

A avaliação descritiva das curvas espectrais, não deixa de ser uma forma adequada de abordagem, quando numa primeira fase de conhecimento e interpretação das curvas espectrais. Isto foi comprovado pelos diferentes tipos de curvas espectrais promovidas pelas amostras de terra.

As observações do presente trabalho e anteriores, nos leva a crer na necessidade de determinação de mais padrões espectrais de solos. Por outro lado, também não se pode fixar tipos de curvas com classes de solos, pois dentro de uma mesma unidade de

solo existem variações espectrais. É necessário, portanto, estudar as curvas espectrais, quanto aos tipos como primeira avaliação, porém, também verificar os detalhes das feições e intensidades de reflectância.

É fato que o solo, devido às suas diversas interações físicas e químicas, é um meio complexo para se entender a reflectância. Por outro lado, numa única curva espectral, pode-se obter uma infinidade de informações sobre o solo, sua composição e classificação preliminar.

Como relatado por Ben Dor et al. (1999) é imperativo que estudos dos solos e sua relação com a energia eltromagnética sejam realizados. Há a necessidade de obtenção de padrões espectrais em laboratório, que possam auxiliar futuros trabalhos 
com sensores hiperespectrais como o AVIRIS, avaliado por Baptista et al. (1998). Por outro lado, os dados espectrais obtidos em laboratório, não servem apenas como padrões, mas como método auxiliar em levantamentos de solos, com realizado por Demattê et al. (2001).

É de fato necessário que trabalhos de caracterização espectral e determinação de padrões continuem a ser realizados como feito por Valeriano et al. (1995) e Formaggio et al. (1996). Sem padrões não é possível colocar em prática tal metodologia como auxílio no estudo dos solos e sua variabilidade. Concomitantemente aos estudos básicos sobre o entendimento das relações solo-reflectância, é preciso colocar em prática tais metodologias. 
ANEXOS 


\section{A1 - Descrição e análises do Perfil 1}

A) DESCRIÇÃO GERAL :

CLASSIFICAÇÃO: GLEISSOLO HÁPLICO Ta Distrớfico típico

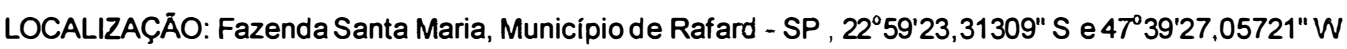

SITUAÇÃO, DECLIVE E COBERTURA VEGETAL SOBRE O PERFIL: sopé de encosta com $5 \%$ de declive sob cultura de cana-de-açúcar.

ALTITUDE: $\approx 477 \mathrm{~m}$

LITOLOGIA: arenitos

MATERIAL ORIGINÁRIO: produtos de meteorizaçāo de arenitos com possivel contribuiçảo de material coluvial arenoso na superficie.

RELEVO LOCAL: ondulado

RELEVO REGIONAL: ondulado

CLIMA: CWa

DESCRITO E COLETADO POR: Carlos Femando Quartaroli

\section{B) DESCRIÇÃO MORFOLÓGICA:}

Ap $\quad 0-25 \mathrm{~cm} ; 7,5$ YR 3,5/1,6 úmido; 8,5 YR 5,2/2,3 seco; areia franca; fraca, pequena, granular ; macia, muito friável, não plástico e não pegajoso, transição abrupta e ondulada.

E 25 - $27 \mathrm{~cm} ; 7,0$ YR 4,1/1,9 úmido; 7,7 YR5,1/2,8 seco; areia franca; fraca, pequena. granular, macia, muito friável, ano plástico, não pegajoso, transição abrupta e ondulada.

Btg $27-60 \mathrm{~cm} ; 7,9$ YR 3,8/1,3 úmido; 9,1 YR 5,0/2,1 seco; franco-arenoso; maciça, material removido do horizonte quebra-se em fragmentos com grau de coesão forte, forma de blocos angualres e subangulares de tamanho grande; consistência dura a muito dura, firme, ligeiramente plástico e pegajoso; transiçāo abrupta e ondulada.

C $\quad 60-120 \mathrm{~cm} ; 7,3$ YR 4,3/2,2 úmido; 8,4 YR 5,5/3,0 seco; franco-arenoso; maciça, material removido do horizonte quebrase em fragmentos com grau de coesão forte, forma de blocos angulares e subangualres de tamnho grande e médio, consitência dura a ligeiramente dura, friável, ligeiramente plástico e ligeiramente pegajoso, transição gradual e plana.

$\mathrm{Cr} 120-142+\mathrm{cm} ; 6,1$ YR 4,2/2,5 úmido; 7,3 YR 5,2/3,4 seco; franco-arenoso; arenito com cimento argiloso semi-intemperizado, maciça, material removido do horizonte querase em fragmenstos com grau de coesão moderado, forma de blocos subangulares de tamnho grande e médio, consisténcia ligeiramente dura a macia, friável, oligeiramente plástico e ligeiramento pegajoso.

RAIZES: fasciculares de cana-de-açúcar, muitas em $\mathrm{Ap}$, comuns em $\mathrm{Bi}$, raras em $\mathrm{C}$ e $\mathrm{Cr}$. 
C) ANALISES FÍSICAS E QUIMICAS

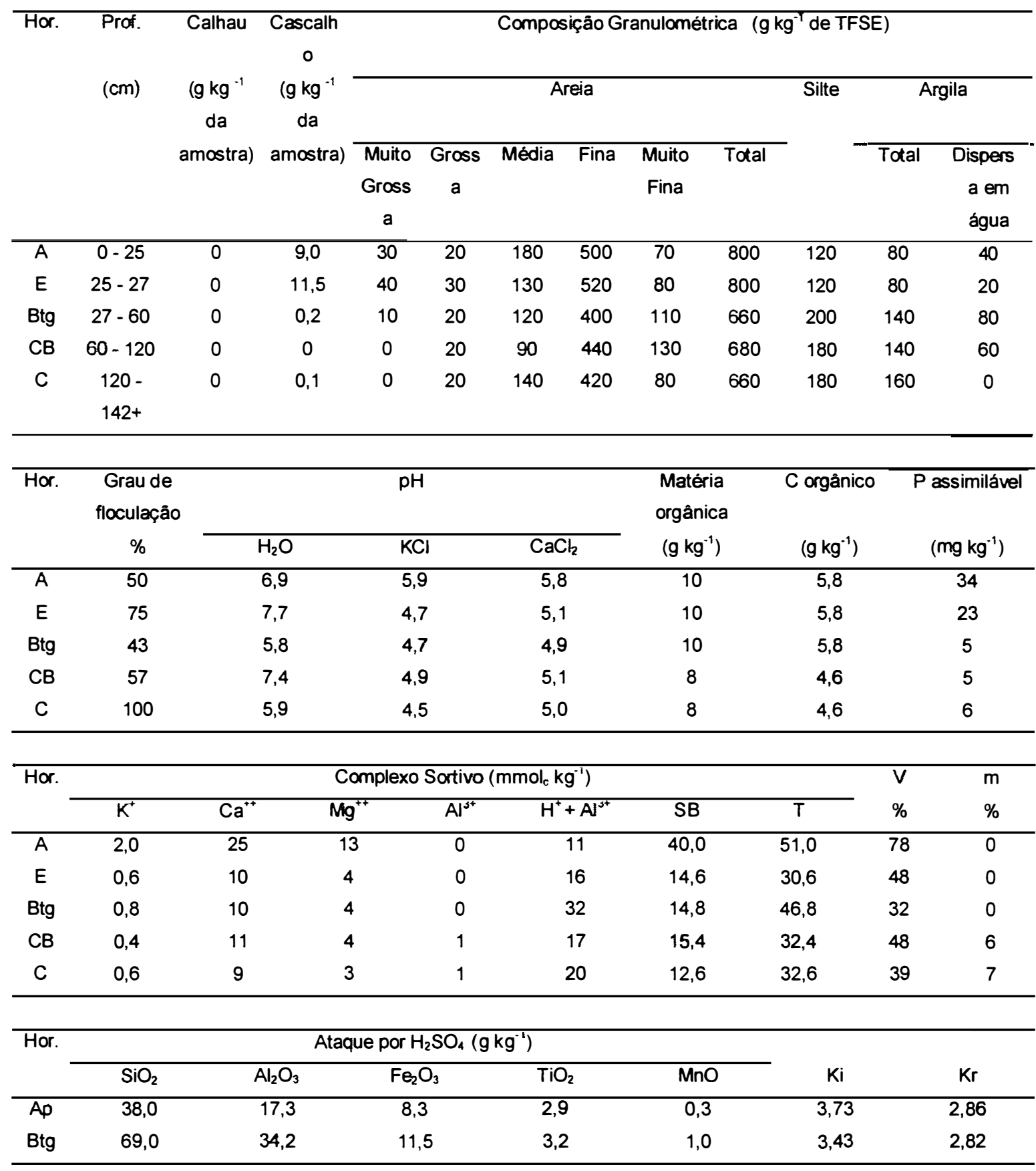

Análise granulométrica: calhau (>20 mm); cascalho ( $20-2 \mathrm{~mm})$; areia muito grossa $(2-1 \mathrm{~mm})$; areia grossa (1 - 0,5 $\mathrm{mm})$; areia média $(0,5-0,25 \mathrm{~mm})$; areia fina $(0,25-0,10 \mathrm{~mm})$; areia muito fina $(0,10-0,05 \mathrm{~mm})$; silte $(0,05-0,002 \mathrm{~mm})$ argila total e dispersa em água $(<0,002 \mathrm{~mm})$ 


\section{A2 - Descrição e análises do Perfil 2}

A) DESCRIÇÃO GERAL :

CLASSIFICAÇÃO:ALISSOLO HIPOCRÓMICO Argilúvico abruptico

LOCALIZAÇẢO: Fazenda Santa Maria, Municipio de Rafard - SP , 2259'27,21148" S e 47039'14,18214" W

SITUAÇÃO, DECLIVE E COBERTURA VEGETAL SOBRE O PERFIL: terço inferior de encosta com declive de $21 \%$

sob cultura de cana-de-açúcar.

ALTITUDE: $\approx 479 \mathrm{~m}$

LITOLOGIA: arenitOS

MATERIAL ORIGINÁRIO: arenitos

RELEVO LOCAL: ondulado

RELEVO REGIONAL: ondulado

CLIMA: CWa

DESCRITOE COLETADO POR: Carlos Fernando Quartaroli

B) DESCRIÇÃO MORFOLÓGICA:

Ap $\quad 0$ - $26 \mathrm{~cm} ; 7,7$ YR 4,0/1,5 úmido; 9,1 YR 5,6/2,4 seco; areia franca; fraca, média, poliédrica subangualr; macia, muito friável, não plástica, não pegajosa; transição abrupta e plana

Bi 26 - $46 \mathrm{~cm} ; 6,0$ YR 4,2/3,1 úmido; 6,6 YR 5,4/3,3 seco, franco-argilo-arenoso; moderada, média a pequena, poliédrica subangular; ligeiramente duro, friável, ligeiramente plástico, ligeiramente pegajoso; transição abrupta e ondulada.

Cr1 46 - $80 \mathrm{~cm} ; 4,1$ YR 4,4/3,0 úmido; 6,0 YR 5,7/3,2 seco; franco-arenoso; arenito com cimento argiloso semiintemperizado, estrutura maciça, grau de coesão forte, material retirado quebra-se em fragmentos rochosos angulares, normalmente de tamnho grande, conssitência muito dura, friável a firme, ligeiramente plástico, ligeiramente pegajosos; transição abrupta e plana. $O$ arenito, embora alterado, ainda apresenta vestígios de laminação paralela.

$\mathrm{Cr} 280-102 \mathrm{~cm} ; 6,8$ YR 4,6/2,5 úmido; 7,7 YR 5,9/2,9 seco; areia, arenito com cimento argiloso semiintemperizadol; estrutura maciça, grau de coesão forte, material retirado quebra-se em fragmentos rochosos angulares, normalment ede tamanho grande, consistência dura, friável, não plástico, não pegajoso; transição gradual e plana.

R $\quad 102-142+; 5,7$ YR 4,6/2,4 úmido; 6,6 YR 6,1/2,6 seco; arenito com cimento argiloso mostrando laminação paralela, estrutura maciça, grau de coesão forte, material retirado quebra-se em fragmentos rochosos angulares, normalment ede tamanho grande, consistência dura, friável, não plástico, não pegajoso.

RAÍZES: fascicualres de cana-de-açúcar e tiririca (Cyperus rotundus) muitas em Ap, com diâmetros menores que 3 mm, comuns em Bi , raras em IICr1.

\section{OBSERVAÇÓES:}

Cerca de metade do volume de Bi está tomado por calhaus e cascalhos, constituidos por seixos e fragmentos rochosos de tamanhos diversos, com diferentes graus de arredondamento (angular, subangular, subarredondado e arredondado) e petrologia diversa, sendo em sua maioria arenitos com forte cimentação por silica. Estes materiais encontram-se esparsos dentro do horizonte, sem uma orientação notável e também ocorem em Ap, porém em número bern mais reduzido. 
O material da camada IICr1 é um pouco diferente das camadas subjacentes, notado principalmente pela sua textura. Possivelmente trata-se de uma camada mais argilosa dos sedimentos que deram origem ao arenito encontrado sob o perfil. 
C) ANÁLISES FISICAS E QUIMICAS

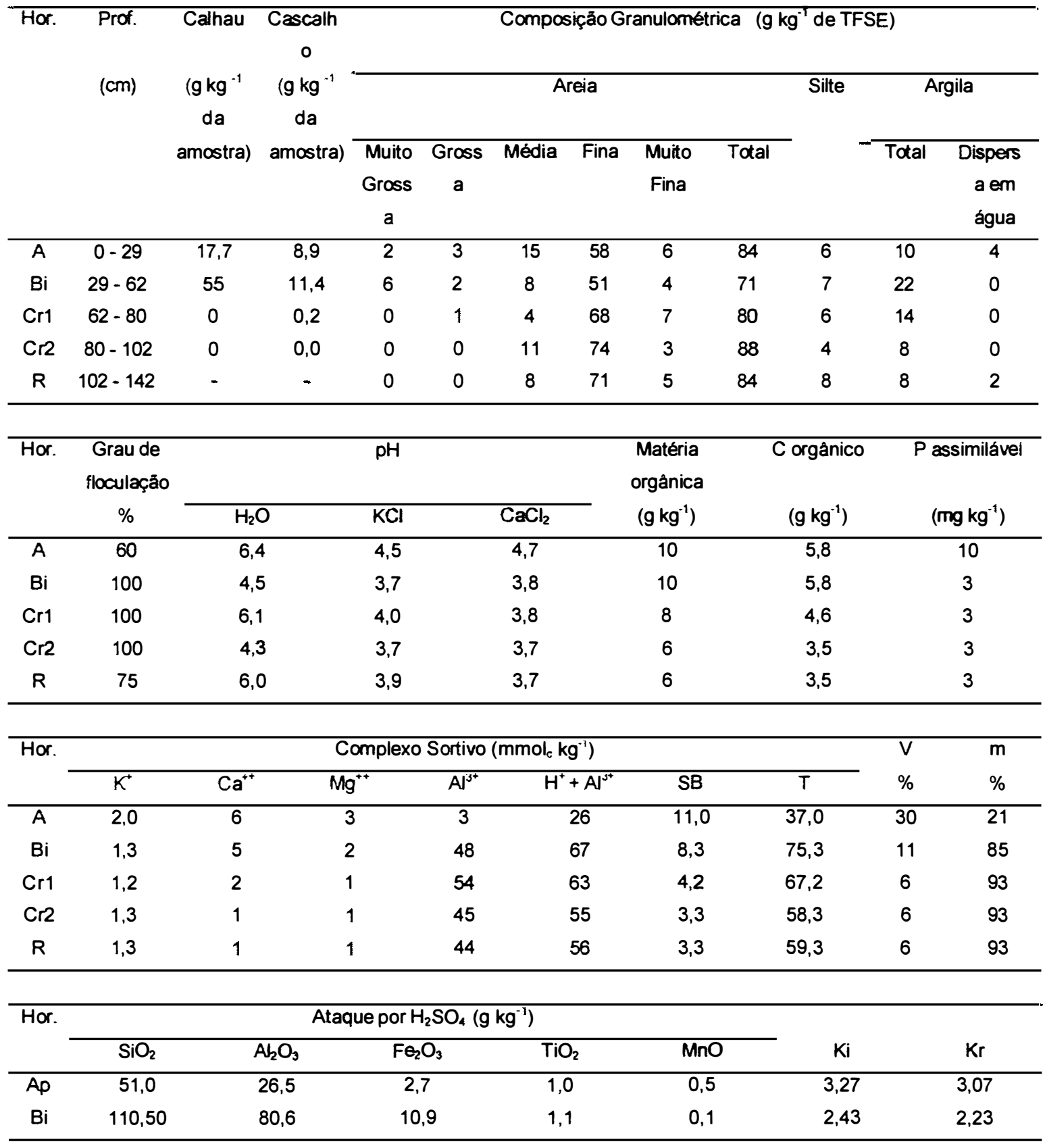

Análise granulométrica: calhau (>20 mm); cascalho ( $20-2 \mathrm{~mm})$; areia muito grossa $(2-1 \mathrm{~mm})$; areia grossa (1 - 0,5 $\mathrm{mm})$; areia média $(0,5-0,25 \mathrm{~mm})$; areia fina $(0,25-0,10 \mathrm{~mm})$; areia muito fina $(0,10-0,05 \mathrm{~mm})$; silte $(0,05-0,002 \mathrm{~mm})$ argila total e dispersa em água $(<0,002 \mathrm{~mm})$ 


\section{A3 - Descrição e análises do Perfil 3}

A) DESCRIÇĀO GERAL :

CLASSIFICAÇĀO: CAMBISSOLO HÁPLICO Ta Eutrófico típico

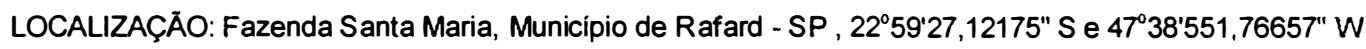

SITUAÇÃO, DECLIVE E COBERTURA VEGETAL SOBRE O PERFIL: local deprimido entre duas encostas com declive de $10 \%$ sob cultura de cana-de-açúcar.

ALTITUDE: $\approx 493 \mathrm{~m}$

LITOLOGIA: folhelhos

MATERIAL ORIGINÁRIO: possivelmente material arenoso de origem coluvial

RELEVO LOCAL: ondulado

RELEVO REGIONAL: ondulado

CLIMA: Cwa

DESCRITO E COLETADO POR: Carlos Femando Quartaroli

\section{B) DESCRIÇĀO MORFOLÓGICA:}

Ap $\quad 0-22 \mathrm{~cm} ; 9,1$ YR 4,0/1,5 úmido; 0,1Y 5,2/2,2 seco; franco-arenoso, moderada, média e pequena, blocos subangulares; ligeiramente duro, friável, ligeiramente plástico e pegajoso; transiçảo clara e ondulada

B $\quad 22$ - $38 \mathrm{~cm} ; 9,0$ YR 4,4/2,3 úmido; 0,1 Y 5,7/3,0 seco; franco-arenoso; moderada, médio, blocos subangulares, ; duro, firme, ligeiramente plástico e pegajoso, transiç̧ó clara e ondulada..

C1 37 - 65 cm; 8,3 YR 4,7/3,4 úmido; 9,2 YR 5,8/4,0 seco; franco-argilo-arenoso, forte, médiae grande, blocos subangulares; duro, firme, liogeiramente plástico e pegajoso, transiçảo gradual e ondulada

Cr 65 - 106 cm ; 7,8 YR 4,8/3,6 úmido; 9,1 YR 6,0/4,1 seco; franco-argiloso, maciça coerente, material removido do horizonte quebra-se em fragmentos rochosos em forma de blocos angualres, alguns laminares, de tamnho grande com grau de coesảo forte, alguns conservam vestigios da laminação caracterr'sitica do horizonte subjacente, porém tendem a adquiri uma cor homogênea; a conssitefencia dos fragmentos é dura, firme, plástica e pegajosa; transição gradual e ondulada.

$\mathrm{R} \quad 106-150+\mathrm{cm}$; folhelho, lâminas com espessura predominante inferior a $1 \mathrm{~mm}$ alternando cores amareladas e esbranquiçadas

RAIZES: 
PERFIL 03

C) ANÁLISES FISICAS E QUIMICAS

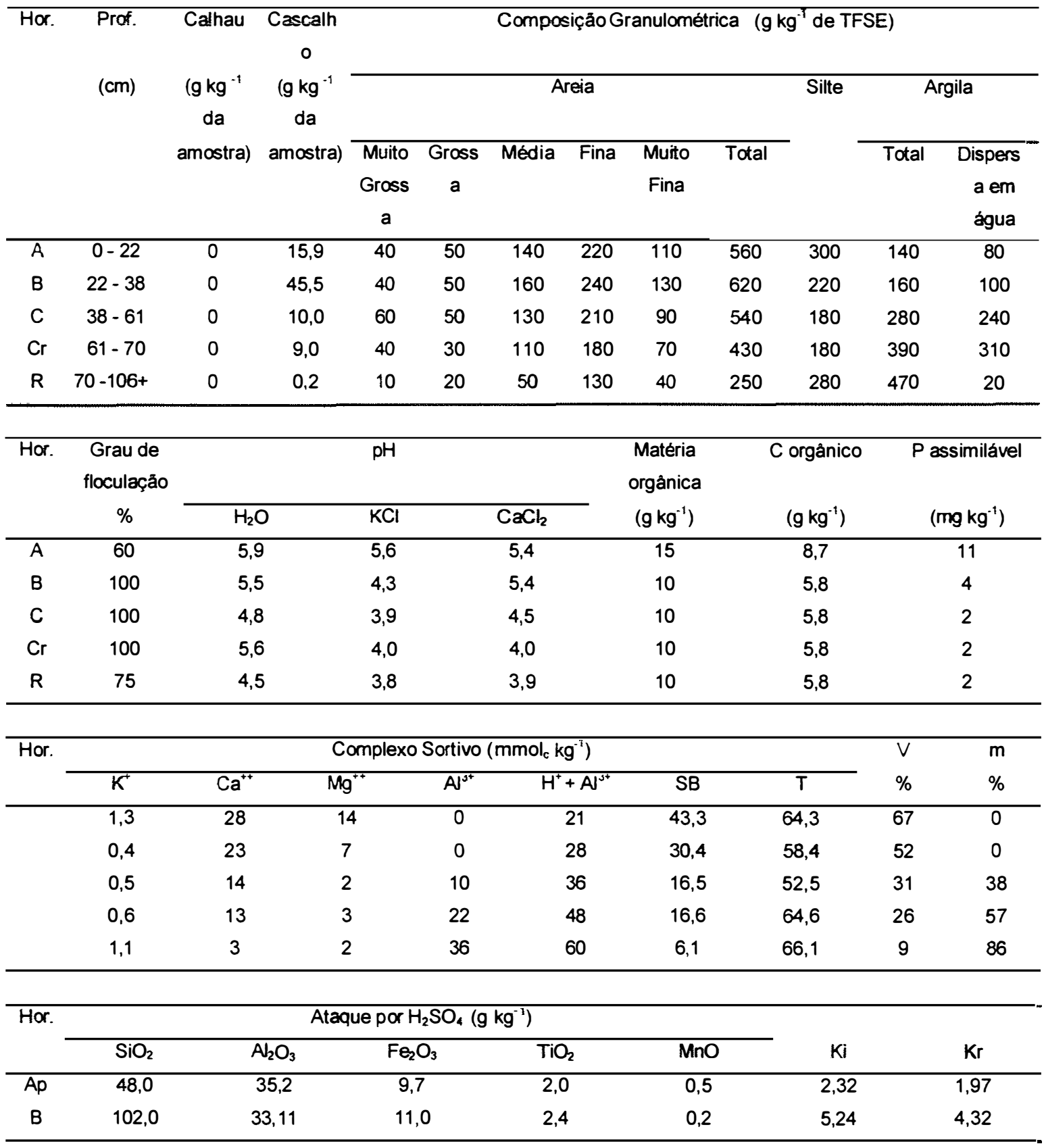

Análise granulométrica: calhau (>20 mm); cascalho ( $20-2 \mathrm{~mm}$ ); areia muito grossa (2 - $1 \mathrm{~mm})$; areia grossa (1 - 0,5 $\mathrm{mm})$; areia média $(0,5-0,25 \mathrm{~mm})$; areia fina $(0,25-0,10 \mathrm{~mm})$; areia muito fina $(0,10-0,05 \mathrm{~mm})$; silte $(0,05-0,002 \mathrm{~mm})$ argila total e dispersa em água $(<0,002 \mathrm{~mm})$ 


\section{A4 - Descrição e análises do Perfil 4}

A) DESCRIÇÃO GERAL :

DATA: 01/12/2000

CLASSIFICAÇÃO:

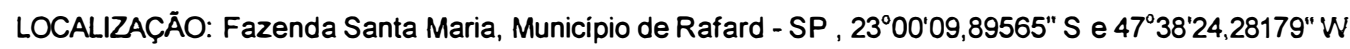

SITUAÇÃO, DECLIVE E COBERTURA VEGETAL SOBRE O PERFIL: local plano em topo de encosta com $2 \%$ de

declive sob cultura de cana-de-açúcar.

ALTITUDE: $\approx 567 \mathrm{~m}$

LITOLOGIA: rochas eruptivas básicas (diabásios)

MATERIAL ORIGINÁRIO: produtos de meteorização de diabásios

RELEVO LOCAL: ondulado

RELEVO REGIONAL: ondulado

CLIMA: CWa

DESCRITOE COLETADO POR: Carlos Fernando Quartaroli

\section{B) DESCRIÇÄO MORFOLÓGICA:}

A1p $\quad 0$ - $10 \mathrm{~cm} ; 2,1$ YR 3,6/1,8 úmido; 3,7 YR 4,2/2,7 seco; muito argiloso; forte, média e pequena, granular e grumosa; duro, firme, muito plástico, muito pegajoso, transição abrupta e ondulada.

A2 $10-30 \mathrm{~cm} ; 1,6$ YR 3,7/2,2 úmido; 3,3 YR 4,3/3,1 seco; muito argiloso; maciça, grau de coesão forte, material removido quebra-se em blocos angulares, de tamnho extremamente grandes, nunca menor de $10 \mathrm{~cm}$; extremamente duro, extremamente firme, muito plástico e muito pegajoso, transiçảo abrupta e plana.

Bt1 30 - $67 \mathrm{~cm} ; 0,6$ YR 3,8/2,8 úmido; 2,7 YR 4,4/3,8 seco; muito argiloso; forte, grandes e médios, poliédrica angular; cerosidade forte e abundante; duro, firme, muito plástico, muito pegajoso; transiçảo gradual e plana.

Bt2 67 - $90 \mathrm{~cm} ; 0,7$ YR 3,7/2,4 úmido; 2,3 YR 4,2/3,5 seco; muito argiloso; moderada a fraca, média a pequena, poliédrica subangular que se desfaz em forte, muito pequena, granular; cerosidade forte e comum; ligeiramente duro, frável, muito plástico e muito pegajoso; transição gradual e plana

Bw $90-126+\mathrm{cm} ; 0,8$ YR 3,6/2,4 úmido; 0,8 YR 3,6/2,4 seco; muito argiloso; maciça porosa que se desfaz em forte, muito pequena, granular, macio, muito friável, muito plástico e muito pegajoso.

RAízES: fasciculares de cana-de-açúcar, muitas em A1p restritas às linhas de cultivo, com tendência a crescimento horizontal. Raizes nảo conseguem penetração em A2, há raras ocorrências ocupando os espaços abertos por fraturas.

\section{OBSERVAÇÓES:}

O horizonte $A$ encontra-se profundamente alterado por práticas agricolas. $O$ grau de compactação é forte da superficie até a profundidade aproximada de $30 \mathrm{~cm}$. A estrutura descrita em A1p refere-se a áreas ocupadas por linhas de cultivo; em entrelinhas, a estrutura é semelhante a descrita em $A 2$, com clara influência da compactação. $O$ solo estava bastante seco quando descrito, com fraturas na superficie que se aprofundavam até o limite inferior de A2. Há sinais de aplicaçảo de gesso agricola e de residuos orgånicos da indústria sucro-alcooleira. Estes residuos sảo visiveis formando grumos em A1p ou ocupando fraturas das camadas compactadas em A ou ainda acumulados nos macroporos interagregados da parte superior de Bt. Há presença de minhocas no solo, apenas nos locais onde há esses residuos orgånicos acumulados. Sảo comuns em A e na parte superior de Bt1 a presença de estruturas revestidas por uma película preta de valor 2 e croma 1 pela carta de Munsell. 
No horizonte Bw ocorre e a presença de cascalhos constituidos por fragmentos de diabł́sio bastante intemperizados. 
PERFIL 04

C) ANÁLISES FISICAS E QUIMICAS

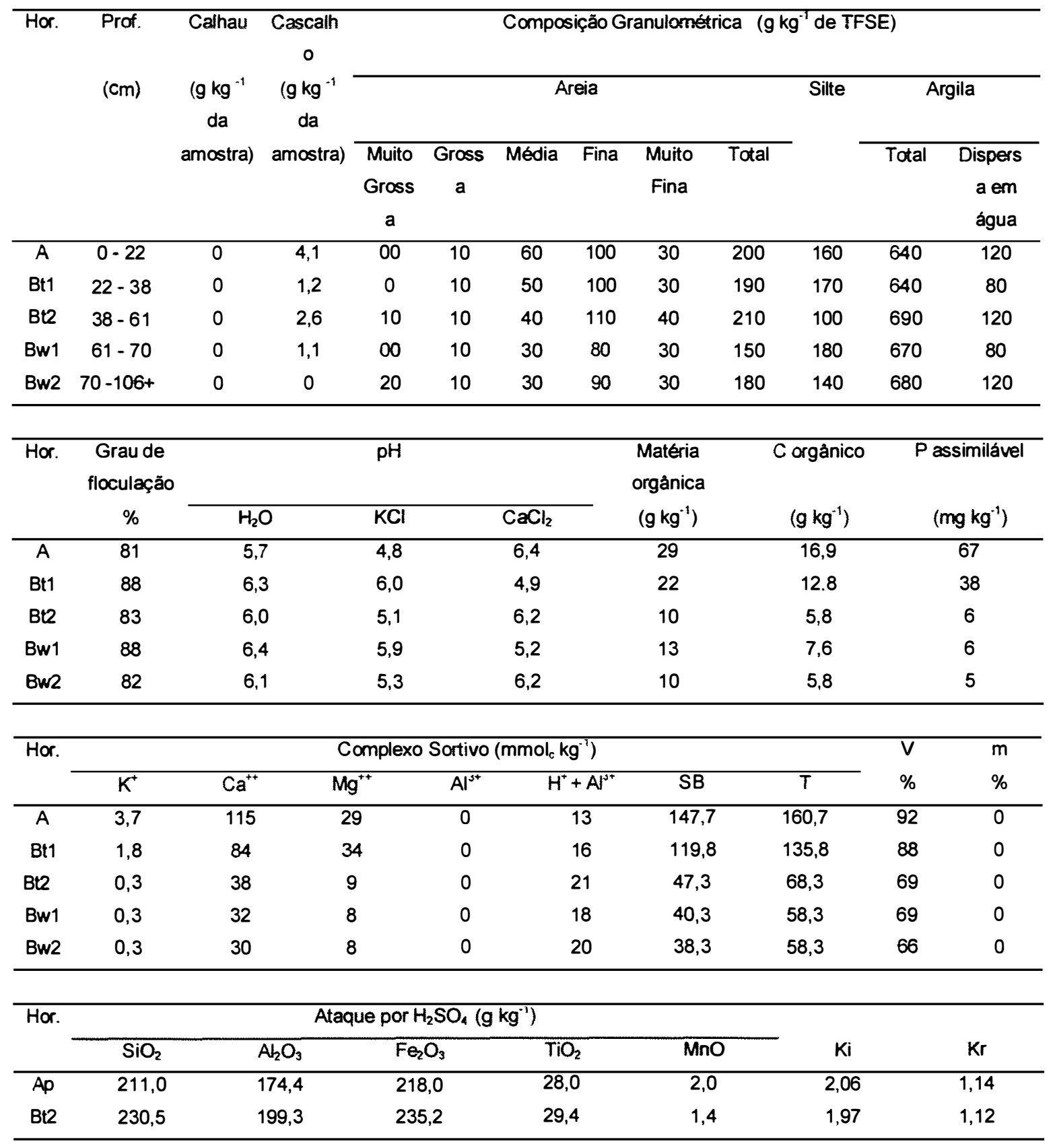

Análise granulométrica: calhau (>20 mm); cascalho ( $20-2 \mathrm{~mm}$ ); areia muito grossa (2 - $1 \mathrm{~mm})$; areia grossa (1 - 0,5 $\mathrm{mm})$; areia média $(0,5-0,25 \mathrm{~mm})$; areia fina $(0,25-0,10 \mathrm{~mm})$; areia muito fina $(0,10-0,05 \mathrm{~mm})$; silte $(0,05-0,002 \mathrm{~mm})$ argila total e dispersa em água $(<0,002 \mathrm{~mm})$ 


\section{A5 - Descrição e análises do Perfil 5}

A) DESCRIÇÃO GERAL :

CLASSIFICAÇÃO: CHERNOSSOLO HÁPLICO Órtico típico

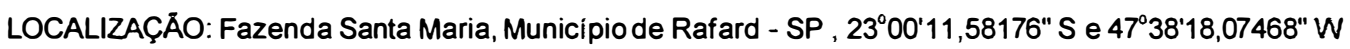

SITUAÇĀO, DECLIVE E COBERTURA VEGETAL SOBRE O PERFIL: terço médio de encosta com $17 \%$ de declive sob cultura de cana-de-açúcar.

ALTITUDE: $\approx 548 \mathrm{~m}$

LITOLOGIA: rochas eruptivas básicas (diabásios)

MATERIAL ORIGINÁRIO: produto da meteorização de diabásios

RELEVO LOCAL: ondulado

RELEVO REGIONAL: ondulado

CLIMA: CWa

DESCRITO E COLETADO POR: Carlos Fernando Quartaroli

\section{B) DESCRIÇÃO MORFOLÓGICA:}

Ap $\quad 0$ - $18 \mathrm{~cm} ; 3,3$ YR 3,5/1,6 úmido; 5,0 YR 4,2/2,4 seco; argila; forte, grande e média, blocos subangualres; muito duro, muito firme, plástico e pegajoso; transição clara e plana

$\mathrm{Bi} \quad 18$ - $24 \mathrm{~cm} ; 4,1$ YR 3,7/2,0 úmido; 7,0 YR 4,8/3,1 seco; franco-argilo-arenoso; moderada, pequena e média; blocos subangulares, ligeiramente duro, friável, ligeiramente plástico e ligeiramente pegajoso; transiçảo clara e plana

CB $24-50 \mathrm{~cm} ; \quad 5,0$ YR 3,8/2,1 úmido; 7,6 YR 5,0/3,2 seco; franco-argilo-arenoso; moderada, pequena, blocos subangulares ligeiramente dura, friável, ligeiramente plástico e ligeiramente pegajoso; transição clara e plana.

C $\quad 50-133^{+} \mathrm{cm} ; 5,0$ YR 3,8/2,1 úmido e 7,6 YR 5,0/3,2 seco; franco-argilo-arenoso, maciça porosa pouco coerente; materaila removido se desfaz em material solto ou fragemntos rochosos de diversos tamanhos com conssistência macia e muito friável; nảo plástico e ligeiramente pegajoso. O grau de intemprismo do material varia dentro do horuizonte. Há zonas menos intemprizadas dentro do horizonte, com material de textura mais grosseira e fragemntos de rochas com diversos graus de alteração e até a ocorrência de mataçōes de dibásio com o característica esfoliaçảo esferoidal.

RAízES: fasciculares de cana-de-açúcar muitas em Ap e Bi com até $5 \mathrm{~mm}$ de diâmetro; raras no restante do perfil com até $3 \mathrm{~mm}$ de diâmetro. 
C) ANÁLISES FISICAS E QUIMICAS

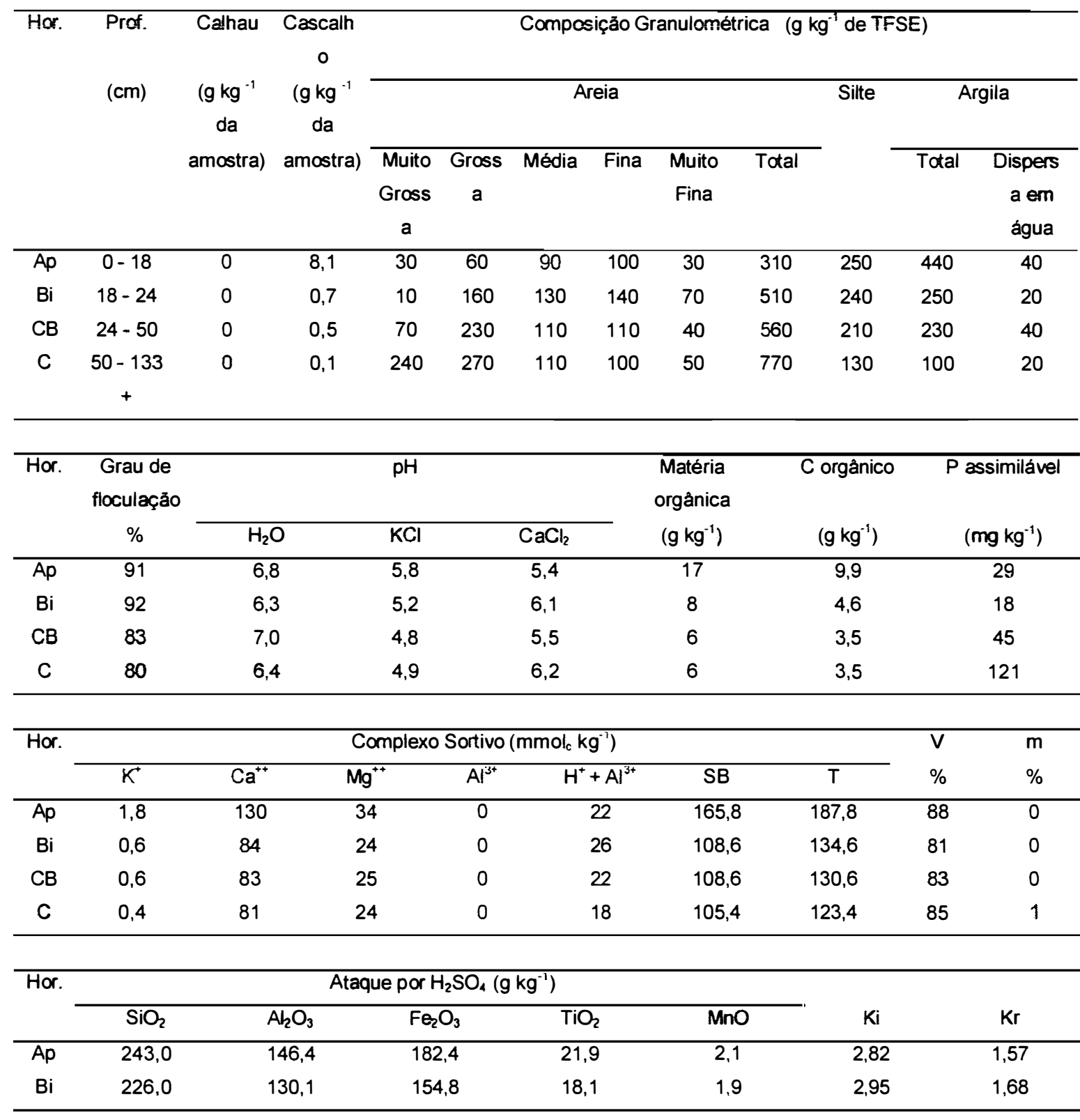

Análise granulométrica: calhau (>20 mm); cascalho ( $20-2 \mathrm{~mm})$; areia muito grossa $(2-1 \mathrm{~mm})$; areia grossa $(1-0,5$ $\mathrm{mm})$; areia média $(0,5-0,25 \mathrm{~mm})$; areia fina $(0,25-0,10 \mathrm{~mm})$; areia muito fina $(0,10-0,05 \mathrm{~mm})$; silte $(0,05-0,002 \mathrm{~mm})$ argila total e dispersa em água $(<0,002 \mathrm{~mm})$ 


\title{
A6 - Descrição e análises do Perfil 6
}

\author{
A) DESCR!ÇÃO GERAL : \\ CLASSIFICAÇÃO: CAMBISSOLO HÁPLICO Eutroférico léptico \\ LOCALIZAÇÃO: Fazenda Santa Maria, Municipio de Rafard - SP , 2300'12,08020" S e 47 38'11,43594" W \\ SITUAÇÃO, DECLIVE E COBERTURA VEGETAL SOBRE O PERFIL: terço inferior de encosta com $13 \%$ de declive \\ sob cultura de cana-de-açúcar. \\ ALTITUDE: $\approx 517$ \\ LITOLOGIA: siltitOS \\ MATERIAL ORIGINÁRIO: produtos de meteorização de siltitos com contribuiçảo de material coluvial provenientes da \\ meteorização de diabásios em Ap e Bi. \\ RELEVO LOCAL: ondulado \\ RELEVO REGIONAL: ondulado \\ CLIMA: Cwa \\ DESCRITOE COLETADO POR: Carlos Femando Quartaroli
}

\section{B) DESCRIÇÃO MORFOLÓGICA:}

Ap $\quad 0-24 \mathrm{~cm} ; 3,3$ YR 3,6/1,5 úmido; 3,8 YR 3,9/2,1 seco; argila; forte, grande e média, blocos subangulares, muito a extremamente duro, muito firme, plástico e pegajoso; cerosidade fraca e e pouca, presença de pequena quantidade de cascalhos, composta de fragemntos rochosos de constitução semelhante a rocha subjacente.; transição

Bi $\quad 24-51 \mathrm{~cm} ; 1,6$ YR 3,7/2,2 úmido; 3,3 Yr 4,2/3,1 seco; muito argilosa com cascalhos; forte, grande e média blocos subangulares, muito a extremamente duro, muito firme, plástico e pegajoso, cerosidade moderada e comum; os cascalhos presentes sảo fragemntos rochosos de constituição semelhante a rocha subjacente; transição

$\mathrm{Cr} \quad 51-75 \mathrm{~cm} ; 3,0$ YR 4,5/3,6 úmido; 5,0 YR 6,0/4,4 seco; rocha semi-intemprizada (siltitos) e extrememtne fraturada que se fragmenta em blocos angulares com tamnho entre 2 e $40 \mathrm{~mm}$ ao ser retirada do perfil. Presença de material solto (areia, silte, argila) preenchendo fraturas, sobretudo as de maior diâmetro, compreendendo menos que $10 \%$ do volume de amterial do horizonte; fragmentos rochosos extrememnte duros e extrememtne firmes; transição

R $\quad 75-140^{+} \mathrm{cm} ; 9,9$ YR 4,9/3,0 úmido; 0,3 Y 6,6/3,5; folhelhos

RAIZES: fasciculares de cana-de-açúcar com diâmetros inferiores a $5 \mathrm{~mm}$, comuns nas linhas de cultivo e poucas nas entrelinhas em Ap; raras no restante do perfil. A maior parte das raizes ocupa os espaços interagregados, poucas conseguem penetrar o material compactado dos horizontes superficiais. Em $\mathrm{R}$ e $\mathrm{Cr}$ as raizes ocupam as fraturas das rochas.

\section{OBSERVAÇÓES:}

Compactação forte em Ap e Bi formando blocos adensados de grande tamnho. 
C) ANÁLISES FISICAS E QUIMICAS

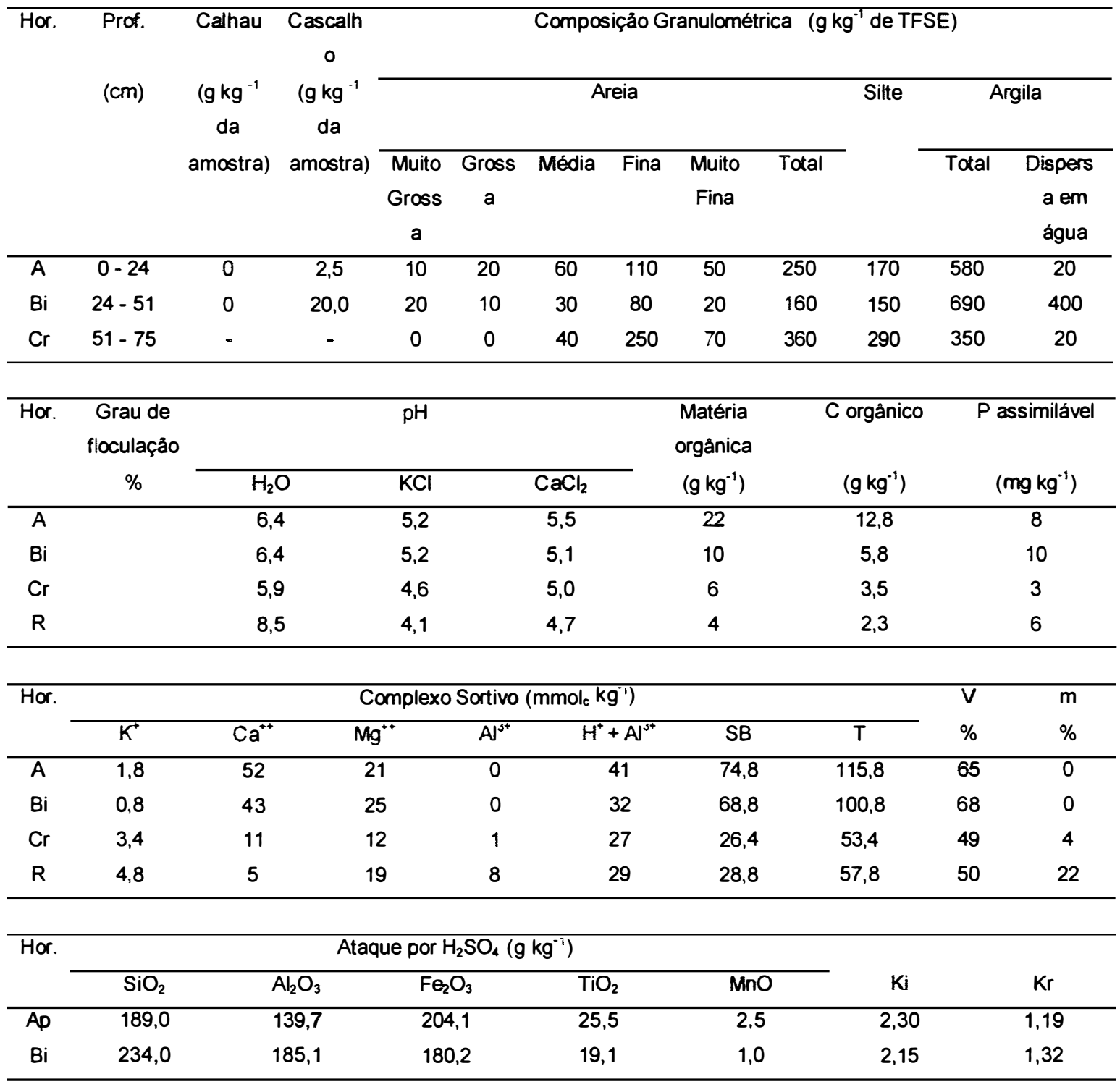

Análise granulométrica: calhau (>20 mm); cascalho ( $20-2 \mathrm{~mm})$; areia muito grossa $(2-1 \mathrm{~mm})$; areia grossa (1 - 0,5 $\mathrm{mm})$; areia média $(0,5-0,25 \mathrm{~mm})$; areia fina $(0,25-0,10 \mathrm{~mm})$; areia muito fina $(0,10-0,05 \mathrm{~mm}) ;$ silte $(0,05-0,002 \mathrm{~mm})$ argila total e dispersa em água $(<0,002 \mathrm{~mm})$ 


\section{A7 - Descrição e análises do Perfil 7}

A) DESCRIÇÃO GERAL :

CLASSIFICAÇÃO: NEOSSOLO LITÓLICO Distrớfico típico

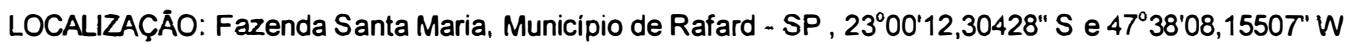

SITUAÇẢO, DECLIVE E COBERTURA VEGETAL SOBRE O PERFIL: terço inferior de encosta com $27 \%$ de declive sob cultura de cana-de-açúcar.

ALTITUDE: $\approx 500 \mathrm{~m}$

LITOLOGIA: siltitos

MATERIAL ORIGINÁRIO: produto de alteração de siltitos

RELEVO LOCAL: ondulado

RELEVO REGIONAL: ondulado

CLIMA. Cwa

DESCRITO E COLETADO POR: Carlos Femando Quartaroli

\section{B) DESCRIÇĀO MORFOLÓGICA:}

Ap $\quad 0-20 \mathrm{~cm} ; 6,8$ Yr 4,6/3,0 úmido; 8,2 YR 6,2/3,3 seco; franco argiloso; grãos simples cascalhenta, solto, lifeiramente plástico, ligeiramente pegajoso; cascalhos constituidos por fragmentos rochosos de folhelhos, com formas poliédricas angulares (predominante) e subangulares e tamnhos até $2 \mathrm{~cm}$, extremamente duros e extrememanete firmes; transiçåo clara e ondulada.

Cr 20-52 cm; 7,3 YR 5,2/3,3 úmido; 8,8 YR 7,0/3,4 seco; franco-argiloso muito cascalhento; graos simples com predomínio da fração cascalho + calhaus (cerca de $90 \%$ do volume) provenientes do fraturamento natural intenso da rocha de origem; ligeirtamente plástico, ligeiramente pegajoso. Fração cascalho é constituida por fragmentos rochosos de folhelhos, com formas poliédricas angulares (predominante) e subangulares e tamnhos até $2 \mathrm{~cm}$., extremamente duros e extremamanete firmes; transição clara e plana.

R1 52 - $82 \mathrm{~cm} ; 9,9$ YR 5,2/3,5 úmido ; 0,1 Y 6,7/3,9 seco; folhelho com fraturas verticais naturais fromando fragmentos poliédricos angulares de tamanhos diversos (de 0,5 até $15 \mathrm{~cm}$ )

R2 $82-120+\mathrm{cm} ; 0,1$ Y 5,2/2,8 úmido; 0,6 Y 7,1/2,6 seco; folhelhos com poucos fraturas verticais. Material removido do perfil destac-ase em grandes láminas ao longo do plano natural de esfoliação.

RAIZES: fascicualres de cana-de-açúcar em Ap, com diåmetros menores que $3 \mathrm{~mm}$, comuns em Ap, raras em B. 
PERFIL 07

C) ANÁLISES FISICAS E QUIMICAS

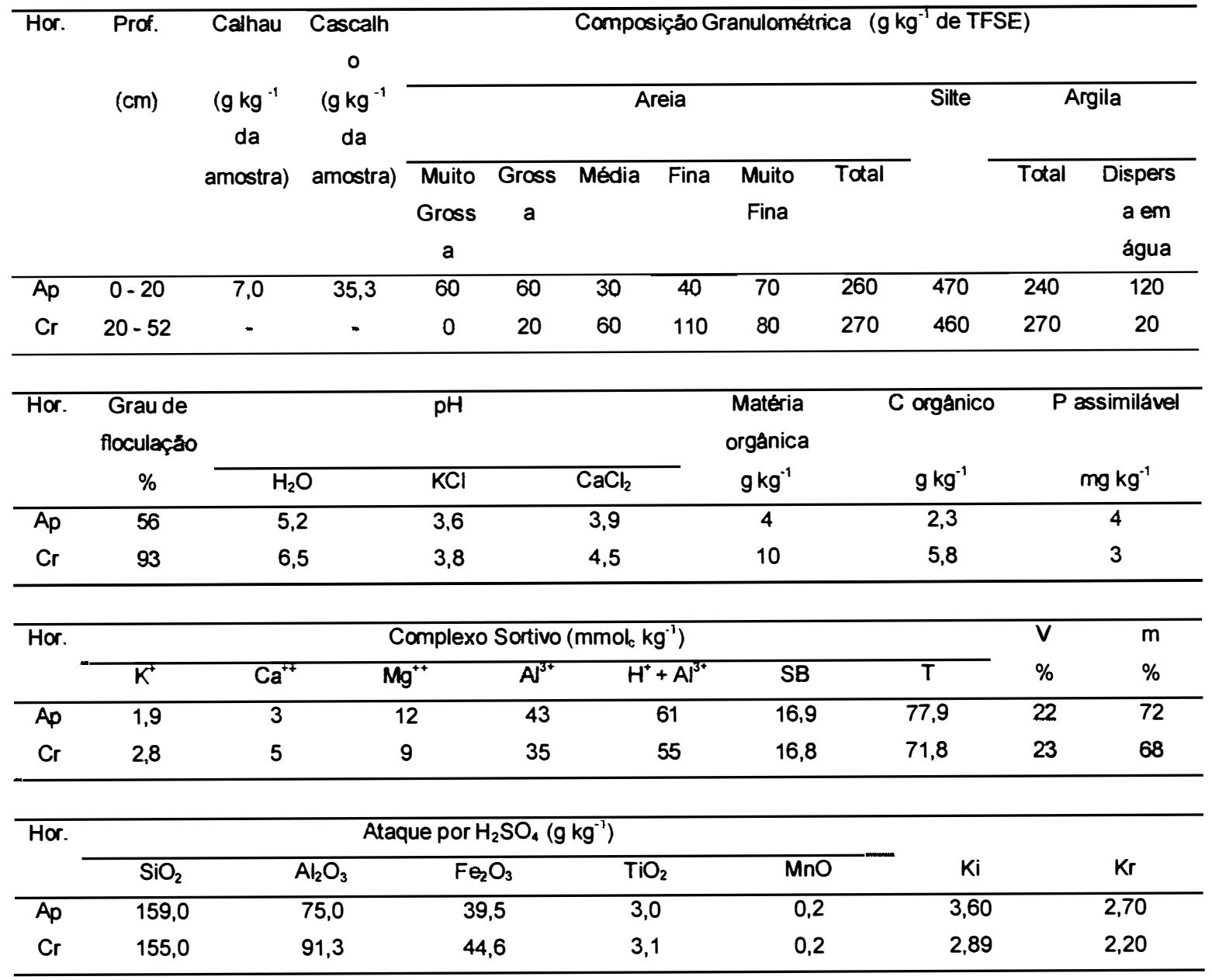

Análise granulométrica: calhau (>20 mm); cascalho ( $20-2 \mathrm{~mm})$; areia muito grossa $(2-1 \mathrm{~mm})$; areia grossa (1 - 0,5 $\mathrm{mm})$; areia média $(0,5-0,25 \mathrm{~mm})$; areia fina $(0,25-0,10 \mathrm{~mm})$; areia muito fina $(0,10-0,05 \mathrm{~mm})$; silte $(0,05-0,002 \mathrm{~mm})$ argila total e dispersa em água $(<0,002 \mathrm{~mm})$ 


\title{
A8 - Descriçāo e análises do Perfil 8
}

\begin{abstract}
A) DESCRIÇĀO GERAL : CLASSIFICAÇÃO:

LOCALIZAÇĀO: Fazenda Santa Maria, Município de Rafard - SP , 2300'01,80861" S e 47 38'12,30147" W

SITUAÇẢO, DECLIVE E COBERTURA VEGETAL SOBRE O PERFIL: terço médio de encosta com $9 \%$ de declive sob cultura de cana-de-açúcar.
\end{abstract}

ALTITUDE: $\approx 521 \mathrm{~m}$

LITOLOGIA: siltitos

MATERIAL ORIGINARIO: produto da meteorizaçăo de siltitos com possivel contribuiçăo de material de origem coluvial RELEVO LOCAL: ondulado

RELEVO REGIONAL: ondulado

CLIMA: Cwa

DESCRITO E COLETADO POR: Carlos Femando Quartaroli

\section{B) DESCRIÇĀO MORFOLÓGICA:}

Ap $\quad 0$ - $25 \mathrm{~cm} ; 6,6$ YR 3,7/1,4 úmido; 8,3 Yr 4,6/2,3 seco; argila; moderada a forte, pequena e muito pequena, poliédrica subangualr; ligeiramente duro; friável, plástico e pegajoso, transiçăo clara e plana.

B 25 - $47 \mathrm{~cm}$; 6,6 YR 4,0/2,2 úmido; 8,4 YR 5,0/3,0 seco; argila; forte, pequena e muito pequena, poliédrica subangular; ligeiramente duro; friável; muito plástico e pegajoso, transiçåo clara e ondulada.

C $\quad 47$ - 64 cm; 3,5 YR 4,6/3,7 úmido; 5,6 YR 6,0/4,3 seco; franco-argiloso muito cascalhento; graos simples com predomínio da fraçăo cascalho (cerca de $60 \%$ do volume). Fração cascalho é constituída por fragmentos rochosos de folhelhos, com formas poliédricas angulares (predominante) e subangulares e tamnhos menores que $1 \mathrm{~cm}$, extremamente duros e extrememanete firmes; transiçăo gradual e ondulada.

Cr $69-92$ cm; 5,9 YR 4,8/3,5 úmido; 7,8 YR 6,5/4,1 seco; ; franco-argiloso muito cascalhento; graos simples com predominio da fraçăo cascalho (cerca de $90 \%$ do volume). Fração cascalho é constituida por fragmentos rochosos de folhelhos, com formas poliédricas angulares (predominante) e subangulares e tamnhos até 2 cm., extremamente duros e extremamanete firmes; transiçăo clara e plana.

$\mathrm{R} \quad 92-140+\mathrm{cm} ; 0,3$ Y 5,4/3,5 úmido; 1,6 Y 7,2/3,6 seco, folhelho com fraturas naturais fromando fragmentos poliédricos angulares de tamanhos diversos (de 0,5 até $15 \mathrm{~cm}$ )

RAIZES: fascicualres de cana-de-açúcar em Ap, com diâmetros menores que 3 mm, muitas em Ap nas linhas de cultivo, raras nas entrelinhas e em B. Raizes tendem a um crescimento horizonteal quando atingem a superfície de do horizonte $B$ afetado por compactaçăo.

\section{OBSERVAÇÓES:}

Os horizontes $\mathrm{C} \mathrm{e} \mathrm{Cr}$ apresentam um aspecto variegado, influenciado pelo padrăo de cores da alteraçăo dos folhelhos; estes originalmente de cor amarela tendem a adquirir uma cor avermalhada conforme aumenta o grau de alteraçăo. A cor mais amarela encontrada, avaliada por carta de Munsell, foi 10 YR 7/4 e a mais vermelha foi 2,5 YR 5/6. Fragmentos normalmente mostram faces avermelhadas quando delimitadas por fraturas naturais, porém quando quebrados; mostram no interior cores maisd amareladas. O horioznte $\mathrm{Cr}$, menos alterado, apresenta um predominio de cores amareladas; o contrário ocorre com o C. 
O grau de compactaçăo verificado em Ap e B é forte. Em Ap é verificado sobretudo nas entrelinhas de cultivo e formam blocos adensados de grande tamanho, extremamente duros. Em $B$, um padrăo de compactação semelhante ocorre, porém é mais generalizada, ocorrendo mesmo nas linhas de cultivo e constituindo um impedimento ao crescimento de raízes. 
C) ANÁLISES FISICAS E QUIMICAS

\begin{tabular}{|c|c|c|c|c|c|c|c|c|c|c|c|c|}
\hline \multirow[t]{3}{*}{ Hor. } & \multirow{3}{*}{$\begin{array}{l}\text { Prof. } \\
\text { (cm) }\end{array}$} & \multirow{3}{*}{$\begin{array}{l}\text { Calhau } \\
\text { (g kg }^{-1} \\
\text { da } \\
\text { amostra) }\end{array}$} & \multirow{3}{*}{$\begin{array}{c}\text { Cascalh } \\
0 \\
\left(\mathrm{~g} \mathrm{~kg}^{-1}\right. \\
\mathrm{da} \\
\text { amostra) }\end{array}$} & \multicolumn{9}{|c|}{ Composição Granulométrica $\left(\mathrm{g} \mathrm{kg}^{-1}\right.$ de TFSE) } \\
\hline & & & & \multicolumn{6}{|c|}{ Areia } & \multirow[t]{2}{*}{ Silte } & \multicolumn{2}{|c|}{ Argila } \\
\hline & & & & $\begin{array}{c}\text { Muito } \\
\text { Gross } \\
\text { a }\end{array}$ & $\begin{array}{c}\text { Gross } \\
a\end{array}$ & Média & Fina & $\begin{array}{l}\text { Muito } \\
\text { Fina }\end{array}$ & Total & & Total & $\begin{array}{c}\text { Dispers } \\
\text { a em } \\
\text { água }\end{array}$ \\
\hline A & $0-25$ & 0 & 30,2 & 40 & 40 & 70 & 150 & 60 & 360 & 210 & 430 & 330 \\
\hline B & $25-47$ & 0 & 30,2 & 100 & 50 & 60 & 130 & 40 & 380 & 170 & 450 & 190 \\
\hline $\mathrm{C}$ & $47-69$ & - & $=$ & 10 & 10 & 100 & 110 & 170 & 400 & 230 & 370 & 0 \\
\hline $\mathrm{Cr}$ & $69-92$ & - & - & 0 & 10 & 50 & 300 & 40 & 400 & 230 & 370 & 0 \\
\hline \multirow[t]{2}{*}{ Hor. } & $\begin{array}{c}\text { Grau de } \\
\text { floculaçảo }\end{array}$ & & \multicolumn{2}{|l|}{$\mathrm{pH}$} & & & \multicolumn{2}{|l|}{$\begin{array}{l}\text { Matéria } \\
\text { orgánica }\end{array}$} & C orgánico & \multicolumn{2}{|c|}{$P$ assimiláve } \\
\hline & $\%$ & \multicolumn{2}{|c|}{$\mathrm{H}_{2} \mathrm{O}$} & \multicolumn{2}{|l|}{$\mathrm{KCl}$} & \multicolumn{2}{|l|}{$\mathrm{CaCl}_{2}$} & $\mathrm{gkg}^{-1}$ & & $\mathrm{~g} \mathrm{~kg}^{-1}$ & \multicolumn{2}{|c|}{$\mathrm{mg} \mathrm{kg}^{-1}$} \\
\hline$A p$ & 23 & \multicolumn{2}{|c|}{5,8} & \multicolumn{2}{|l|}{4,4} & \multicolumn{2}{|l|}{5,3} & 29 & & 16,9 & \multicolumn{2}{|r|}{66} \\
\hline B & 58 & \multicolumn{2}{|c|}{5,5} & \multicolumn{2}{|l|}{4,5} & \multicolumn{2}{|l|}{4,9} & 15 & & 8,7 & \multicolumn{2}{|r|}{5} \\
\hline $\mathrm{C}$ & 100 & \multicolumn{2}{|c|}{6,1} & \multicolumn{2}{|l|}{4,2} & 4,6 & & 10 & & 5,8 & & 3 \\
\hline $\mathrm{Cr}$ & 100 & 8,4 & & 4,4 & & 4,8 & & 8 & & 4,6 & & 3 \\
\hline Hor. & & & & omplexc & Sortivo & $(\mathrm{mmol} \mathrm{k}$ & & & & & $\mathbf{V}$ & $m$ \\
\hline & $K^{+}$ & $\mathrm{Ca}^{++}$ & $\overline{M g}$ & & $\mathrm{Al}^{\mathrm{j}^{+}}$ & & $+\mathrm{Al}^{3^{+}}$ & SB & & $T$ & $\%$ & $\%$ \\
\hline$A p$ & 2,8 & 39 & 1 & & 0 & & 42 & 57,8 & & 99,8 & 58 & 0 \\
\hline B & 1,2 & 19 & 1 & & 2 & & 44 & 31,2 & & 75,2 & 41 & 6 \\
\hline$c$ & 3,7 & 9 & $\varepsilon$ & & 22 & & 56 & 20,7 & & 76,7 & 27 & 52 \\
\hline $\mathrm{Cr}$ & 5,3 & 1 & 1 & & 33 & & 62 & 23,3 & & 85,3 & 27 & 59 \\
\hline Hor. & & & & aque po & $\mathrm{H}_{2} \mathrm{SO}_{4}$ & (\%) & & & & & & \\
\hline & $\mathrm{SiO}_{2}$ & & $\overline{\mathrm{Al}_{2} \mathrm{O}_{3}}$ & $\mathrm{Fe}_{2}$ & & $\mathrm{TiC}$ & & $\mathrm{MnC}$ & & $\mathrm{Ki}$ & & $\mathrm{Kr}$ \\
\hline$A p$ & 174,0 & & 101,5 & $\overline{108}$ & 3,0 & 15 & & 0,8 & & 2,91 & & 1,73 \\
\hline B & 146,0 & & 130,2 & 115 & 5,5 & 12 & & 0,3 & & 1,91 & & 1,22 \\
\hline
\end{tabular}

Análise granulométrica: calhau (>20 mm); cascalho ( $20-2 \mathrm{~mm}$ ); areia muito grossa (2 - $1 \mathrm{~mm})$; areia grossa (1 - 0,5 $\mathrm{mm})$; areia média $(0,5-0,25 \mathrm{~mm})$; areia fina $(0,25-0,10 \mathrm{~mm})$; areia muito fina $(0,10-0,05 \mathrm{~mm})$; silte $(0,05-0,02 \mathrm{~mm})$ argila total e dispersa em água $(<0,002 \mathrm{~mm})$ 


\section{A9 - Descrição e análises do Perfil 9}

A) DESCRIÇĀO GERAL :

CLASSIFICAÇĀO: NEOSSOLO REGOLITICO Distrófico típico

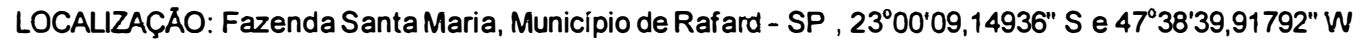

SITUAÇÃO, DECLINE E COBERTURA VEGETAL SOBRE O PERFIL: terço superior de encosta com $8 \%$ de declive sob cultura de cana-de-açúcar.

ALTITUDE: $\approx 542 \mathrm{~m}$

LITOLOGIA: arenitos com cimento argiloso

MATERIAL ORIGINÁRIO: produtos de meteorizaçåo de arenitos com cimento argiloso

RELEVO LOCAL: ondulado

RELEVO REGIONAL: ondulado

CLIMA: CWa

DESCRITOE COLETADO POR: Carlos Fernando Quartaroli

\section{B) DESCRIÇĀO MORFOLÓGICA:}

A1p $0-22 \mathrm{~cm} ; 8,7$ YR 4,3/2,0 úmido; 10 YR 5,9/2,7 seco; franco-arenoso; fraca, muito pequena e pequena, blocos subangulares que se desfazem em gråoe simples; macio, muito friável, năo plástico e nåo pegjoso, transiçåo clara e plana.

A2p 22 - $34 \mathrm{~cm} ; 8,5$ YR 4,4/2,1 ;umido; 9,7 YR 5,8/2,8 seco; franco-arenoso; fraca, ,.muito pequena e pequena, blocos subangulares que se desfazem em grőes simples, macio, muito friável, nåo plástico e nåo pegajoso; transiçåo abrupta e plana

C1 34 - $64 \mathrm{~cm} ; 7,9$ YR 4,5/2,8 úmido; 9,0 YR 5,6/3,5 seco; franco-argilo-arenoso; maciça coerente formada por material de alteraçåo de arenitos com cimento argiloso, muito a extremamente duro, muito firme, plástico, ligeiramente pegajoso, transiçáo clara e plana.

C2 $64-104 \mathrm{~cm}$; coloraçåo variegada úmida, composta de 5 YR 5/6 e 2,5 YR 4/4, cada uma ocupando cerca de metade da superficie do horizonte, com manchas de tamnho grande, amostras trituradas e homogeneizadas apresentaram cor 6,9 YR 4,6/3,4 úmidas e 8,0 YR 5,714,2 secas; franco-argiloso; maciça coerente formada por material de alteraçăo de arenitos com cimento argiloso, extremamente duro, muito firme, plástico e ligeiramente pegajoso, tmsiçăo gradual e ondulada..

$\mathrm{Cr} \quad 104-134^{*} \mathrm{~cm} ; 5$ YR 5/6 úmido com mosqueado 2,5 YR 4/4 úmido, manchas grandes, proeminentes e abundantes ocupando cerca de $40 \%$ da superficie do horizonte; anmostras trituradas e homogeneizadas apresentaram cor 5,6 YR 4,6/3,6 úmidas e 7,0 YR 5,8/4,6 secas franco-argilo-arenoso; maciça coerente formada por arenitos com cimento argiloso semi-intemperizados, extremamente duro, firme a muito firme, plástico e ligeiramente pegajoso.

RAIZES: fasciculares de cana-de-açúcar com diåmetros inferiores a $3 \mathrm{~mm}$, muitas em A1P e A2p, raras em C1. 
PERFIL 09

C) ANÁLISES FISICAS E QUIMICAS

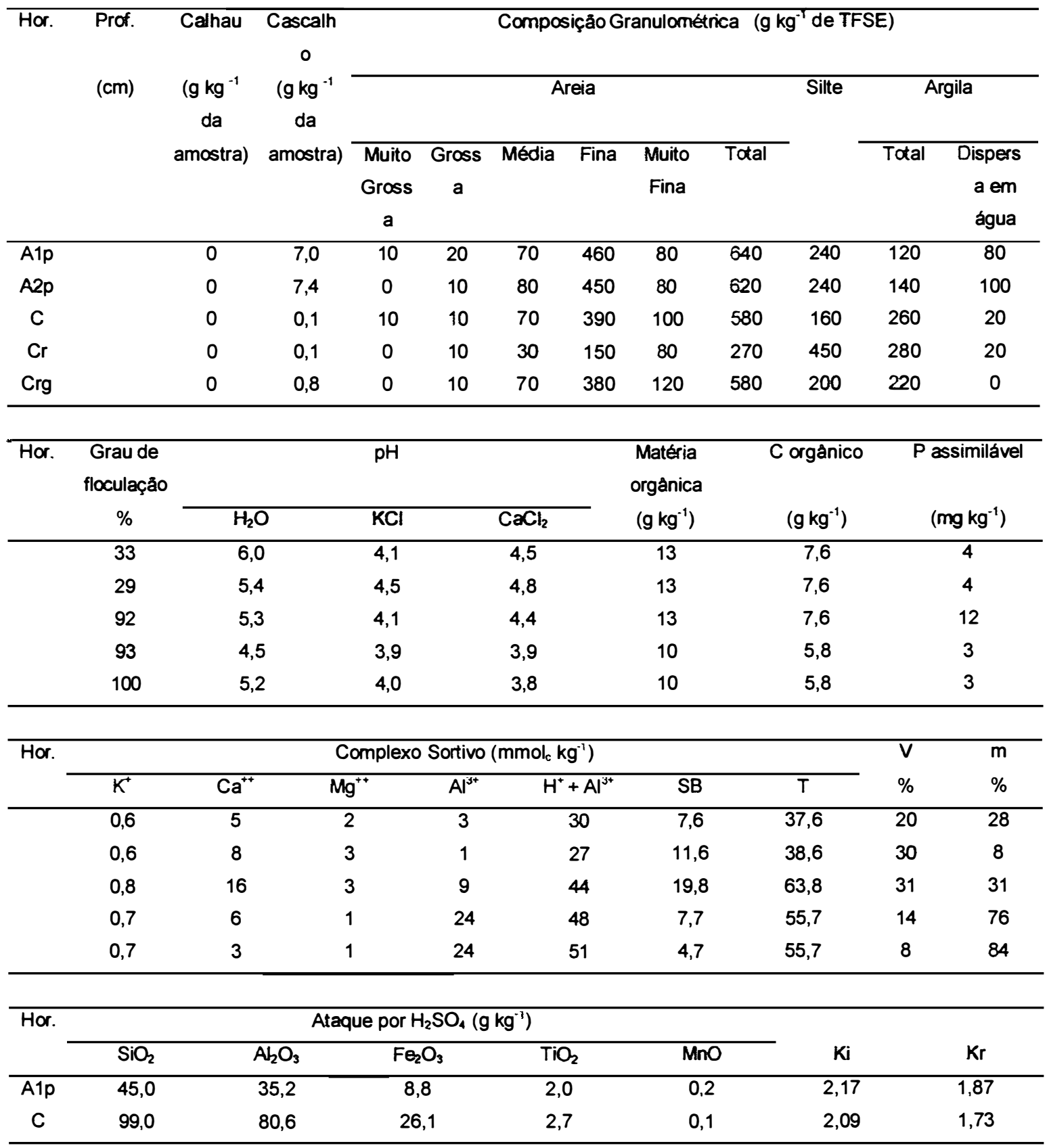

Análise granulométrica: calhau (>20 mm); cascalho ( 20 - $2 \mathrm{~mm})$; areia muito grossa (2 - $1 \mathrm{~mm})$; areia grossa (1 - 0,5 $\mathrm{mm})$; areia média $(0,5-0,25 \mathrm{~mm})$; areia fina $(0,25-0,10 \mathrm{~mm})$; areia muito fina $(0,10-0,05 \mathrm{~mm})$; silte $(0,05-0,002 \mathrm{~mm})$ argila total e dispersa em água $(<0,002 \mathrm{~mm})$ 


\section{A10 - Descrição e análises do Perfil 10}

A) DESCRIÇÃO GERAL :

CLASSIFICAÇĀO: LATOSSOLO VERMELHO AMARELO Distrófico cåmbico

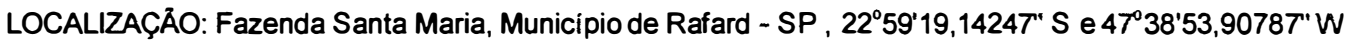

SITUAÇÃO, DECLINE E COBERTURA VEGETAL SOBRE O PERFIL:

ALTITUDE: $\approx 497 \mathrm{~m}$

LITOLOGIA: arenitos com cimento argiloso

MATERIAL ORIGINÁRIO: produtos de meteorizaçåo de arenitos com cimento argiloso

RELEVO LOCAL: ondulado

RELEVOREGIONAL: ondulado

CLIMA: Cwa

DESCRITO E COLETADO POR: Carlos Femando Quartaroli

\section{B) DESCRIÇÃO MORFOLÓGICA:}

Ap $\quad 0-24 \mathrm{~cm} ; 7,2$ YR 3,8/1,5 úmido; 8,3 YR 4,8/2,3 seco; franco-arenoso; fraca muito pequena e pequena blocos subangulares; ligeiramente duro a duro, friável a firme, ligeiramente plástico e ligeiramente pegajoso; transiçåo abrupta e plana.

Bt1 24 - $60 \mathrm{~cm} ; 4,7$ YR 4,1/2,8 úmido; 5,8 YR 4,9/3,6 seco; franco-argilo-arenoso, moderada média e pequena blocos subangulares; duro a ligeiramente duro, friável, plástico e ligeiramente pegajoso; cerosidade fraca e pouca; transiçåo clara e plana.

Bt2 60 - $99 \mathrm{~cm} ; 4,1$ YR 4,2/3,4 úmido; 5,1 YR 5,1/4,2 seco; franco-argilo-arenoso; moderada a fraca pequena e muito pequena blocos subangulares; dura a ligeiramente duro, friável, plástico e ligeiramente pegajoso; transiçåo clara e plana.

BC $99-138^{+} \mathrm{cm} ; 4,7$ YR 4,3/3,4 úmido; 4,6 YR 5,1/4,3 seco; franco-argilo-arenoso; moderada muito pequena e pequena blocos subangulares; ligeiramente duro, friável, plástico e ligeiramente pegajoso.

RAÍZES: fasciculares de cana-de-açúcar com diåmetros inferiores a $3 \mathrm{~mm}$; muitas nas linhas de cyultivo, poucas ou raras nas entrelinhas em Ap; raras no restante do perfil. 
PERFIL 10

C) ANÁLISES FISICAS E QUIMICAS

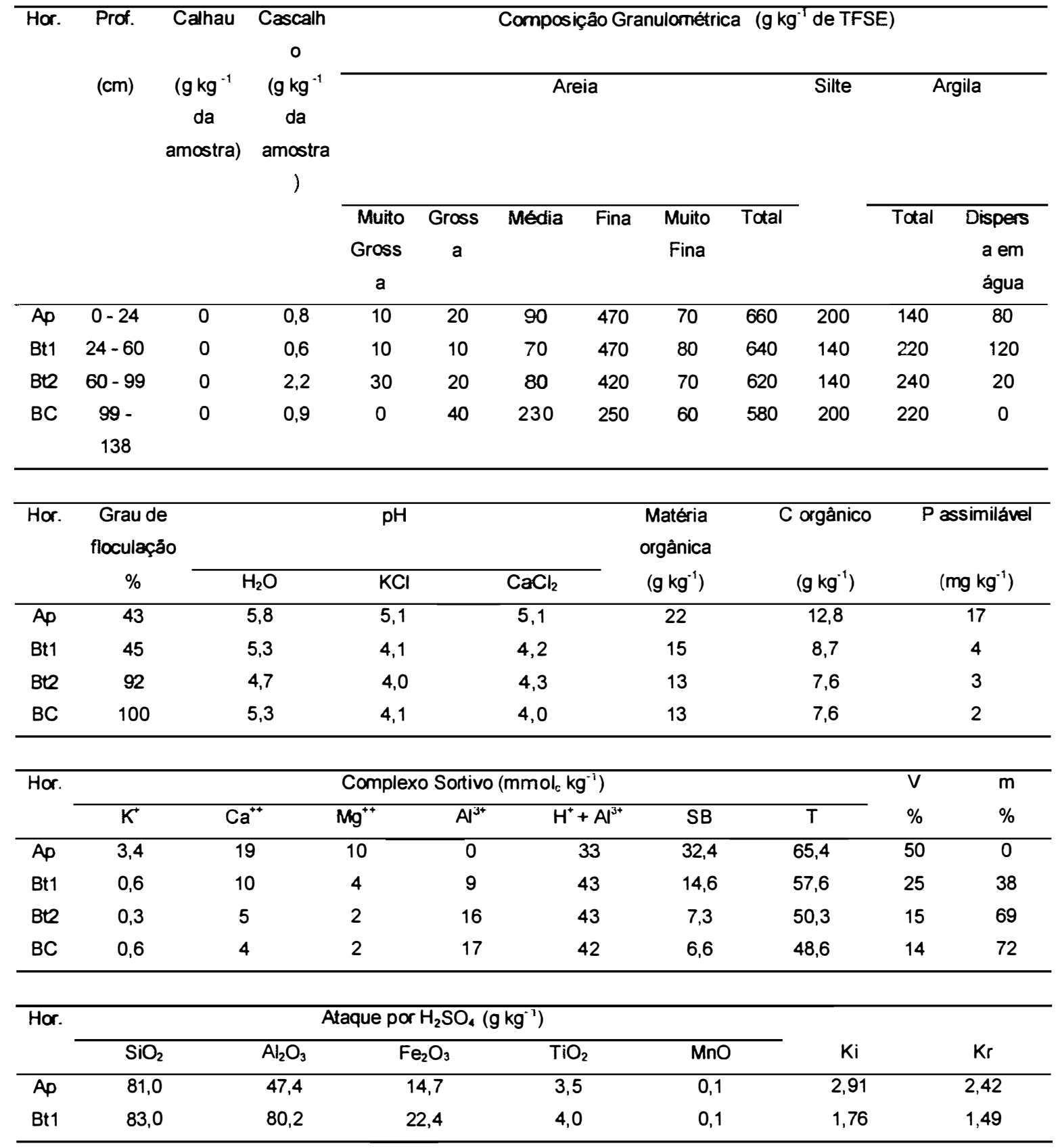

Análise granulométrica: calhau (>20 mm); cascalho ( $20-2 \mathrm{~mm})$; areia muito grossa $(2-1 \mathrm{~mm})$; areia grossa (1 - 0,5 $\mathrm{mm})$; areia média $(0,5-0,25 \mathrm{~mm})$; areia fina $(0,25-0,10 \mathrm{~mm})$; areia muito fina $(0,10-0,05 \mathrm{~mm}) ;$ silte $(0,05-0.002 \mathrm{~mm})$ argila total e dispersa em água $(<0,002 \mathrm{~mm})$ 


\section{A11 - Descrição e análises do Perfil 11}

A) DESCRIÇÃO GERAL :

CLASSIFICAÇÃO: CAMBISSOLO HAPLICO Tb Distrớfico típico

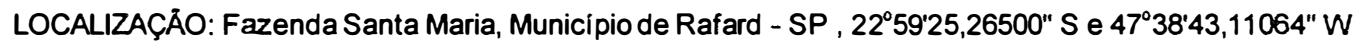

SITUAÇÃO, DECLIVE E COBERTURA VEGETAL SOBRE O PERFIL: Iocal plano ao pé de encosta com $2 \%$ de declive sob cultura de cana-de-açúcar.

ALTITUDE: $\approx 479 \mathrm{~m}$

LITOLOGIA:

MATERIAL ORIGINÁRIO:

RELEVO LOCAL: ondulado

RELEVO REGIONAL: ondulado

CLIMA: CWa

DESCRITOE COLETADO POR: Carlos Fernando Quartaroli

B) DESCRIÇÃO MORFOLÓGICA:

Ap $\quad 0$ - $32 \mathrm{~cm} ; 8,8$ YR 4,0/1,6 úmido; 9,9 YR 5,2/2,3 seco; franco-arenoso; moderada, muito pequena e pequena, blocos subangulares; macio a ligeiraemnte duro, friável a muito friável, ligeiramente plástico e ligeiramente pegajoso; transiçăo abrupta e plana.

Bi $\quad 32$ - $73 \mathrm{~cm}$; 8,0 YR 4,4/2,4 úmido; 9,2 YR 5,6/3,1 seco; franco-argilo-arenoso; moderada, muito pequena (predominante), pequena e média, blocos subangulares; duro, fime, plástico e pegajoso; cerosidade transiçăo clara e plana.

C $\quad 73-130 \mathrm{~cm} ; 6,3$ YR 4,3/3,0 úmido; 7,9 YR 5,5/3,9 seco; argila;

Crg $130-150^{+} \mathrm{cm} ; 5,6$ YR 4,3/3.1 úmido; ; 7,3 YR 5,5/3,7 seco, argila

RAIZES: 


\section{C) ANÁLISES FISICAS E QUIMICAS}

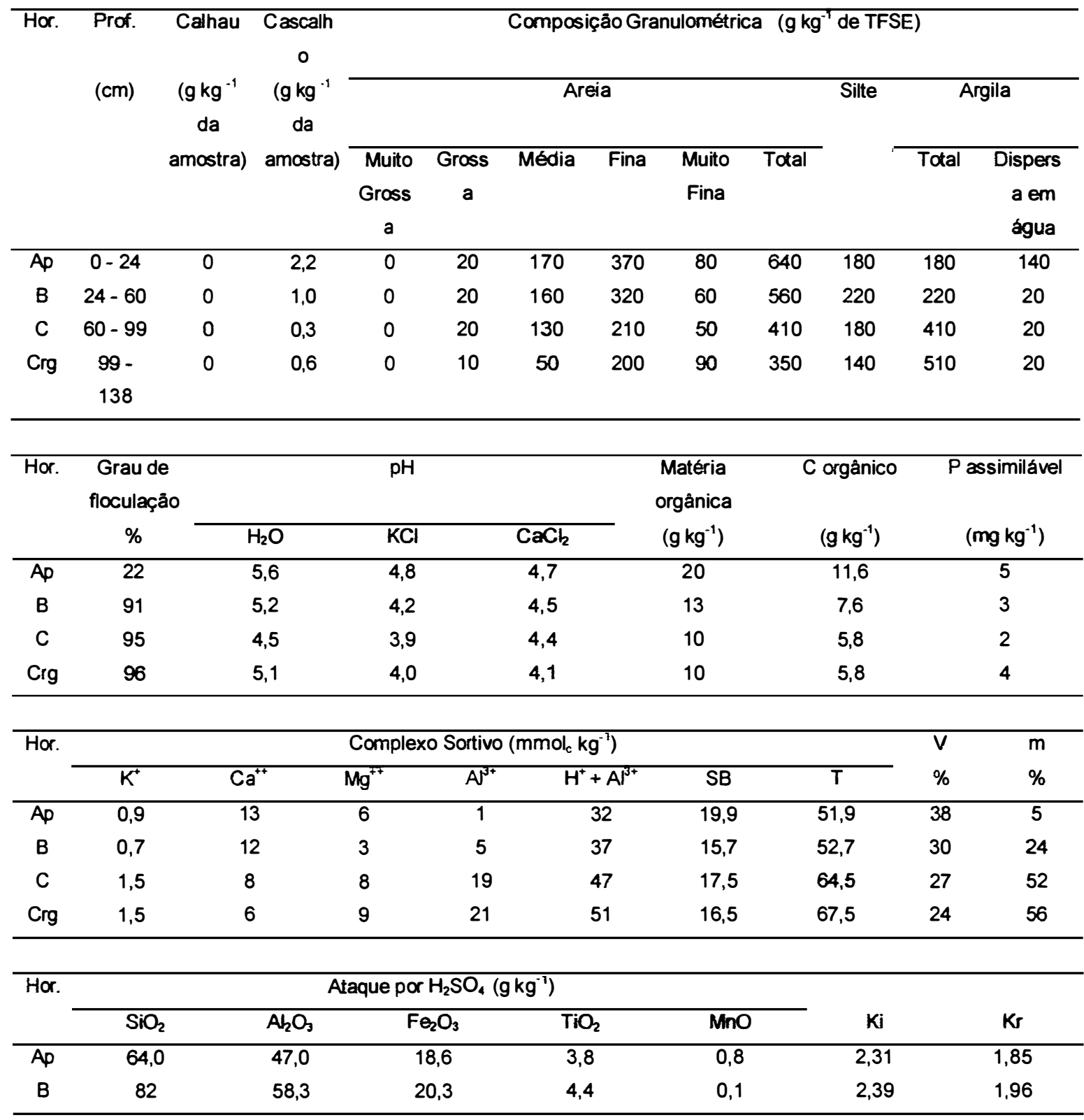

Análise granulométrica: calhau (>20 mm); cascalho ( 20 - $2 \mathrm{~mm})$; areia muito grossa (2 - $1 \mathrm{~mm})$; areia grossa (1 - 0,5 $\mathrm{mm})$; areia média $(0,5-0,25 \mathrm{~mm})$; areia fina $(0,25-0,10 \mathrm{~mm})$; areia muito fina $(0,10-0,05 \mathrm{~mm}) ;$ silte $(0,05-0,002 \mathrm{~mm})$ argila total e dispersa em água $(<0,002 \mathrm{~mm})$ 


\section{A12 - Descrição e análises do Perfil 12}

\section{A) DESCRIÇÃO GERAL : \\ CLASSIFICAÇÃO: ALISSOLO HIPOCRÔMICO Argilúvico abrúptico}

LOCALIZAÇẢO: Fazenda Santa Maria, Municipio de Rafard - SP , 2259'35,37323" S e 47038'44,39989" W

SITUAÇĀO, DECLNE E COBERTURA VEGETAL SOBRE O PERFIL: terço inferior de encosta com $8 \%$ de declive sob cultura de cana-de-açúcar.

ALTITUDE: $490 \mathrm{~m}$

LITOLOGIA: arenitos de granulação fina com cimento argiloso

MATERIAL ORIGINÁRIO: produtos da meteorização de arenitos com possivel contribuição de material coluvial aerenoso em superficie

RELEVO LOCAL: ondulado

RELEVO REGIONAL: ondulado

CLIMA: Cwa

DESCRITO E COLETADO POR: Carlos Femando Quartaroli

\section{B) DESCRIÇÃO MORFOLÓGICA:}

Ap $\quad 0-25 \mathrm{~cm} ; 7,2$ YR 4,1/1,9 úmido; 7,1 YR 5,5/2,6 seco; franco-aerenoso; fraca, peqena e média, poliédrica subangular, macio a ligeiramente duro, muito friável a friável, ligeirtamente plástico e ligeiramente pegajoso, transição clara e plana.

AB 25 - $42 \mathrm{~cm}$; 7,5 YR 4,1/1,9 úmido; 8,6 YR 5,3/2,6 seco, franco-arenoso; moderada, media e pequena, poliédrica subangular; ligeiramente duro, friável, plástico e ligeiramente pegajoso; transição abrupta e plana.

$\mathrm{Bi} \quad 42$ - $63 \mathrm{~cm} ; 7,1$ YR 3,8/1,8 úmido; 8,4 YR 4,9/2,6 seco; franco-argilo-arenoso; forte, pequena e média, poliédrica subangular; cerosidade fraca e comum; duro, firme, plástico e pegajoso, transição clara e plana.

R $63-98 \mathrm{~cm} ; 8,6$ YR 4,7/3,2 úmido; 9,7 YR 6,5/3,8 seco; arenito de granulação fina com cimento argiloso, apresenta-se bastante fraturado onde acumula-se pequenas quantidades de solo, possivelmente migradios do horizonte suprajacente. O material retirado da camada quebra-se em fragmentos angulares, normalmente ao longo das fraturas existentes e apresenta-se extremamente duro e extremamente firme. Ao longo dessas fraturas pode-se observar um intemperismo incipinete da rocha.

Cr 98 - 140+cm; 7,1 YR 4,2/2,4 úmido; 8,2 YR 5,3/3,4 seco; franco arenoso; maciça, grau de coesão moderada , material retirado do horizonte quebra-se em fragmentos angulares de tamnho grande, duros, friáveis, ligeiramente plástico e ligeiramente pegajoso.

RAIZES: fascicualres de cana-de-açúcar, muitas em Ap, com diâmetros menores que $3 \mathrm{~mm}$, comuns em $A B$, raras em $B$ e $R$, neste último ocupando os espaços oriundos das fraturas existentes nas rochas.

\section{OBSERVAÇŌES:}

O material que compōe $\mathrm{Cr}$ apesar de ocupar posição inferior no perfil, apresenta-se mais internperizado que o R. Ambos parecem ter origem em arenitos de granulação fina com cimento argiloso, entretanto devem pertencer a estratos sedimentares distintos. A camada superior aparenta ser mais rica em finos (site e argila) o que pode ter Ihe conferido um maior grau de coesão de suas partículas e maior resistência ao intemperismo. Mesmo apresentando algum grau de inteperismo, a rocha, mesmo úmida não pode ser cortada com pá, o que não permite sua classificação como C ou Cr. Já a camada inferior, com menor proporção de cimento, ooriginou um material menos coeso, menos resistente ao intemperismo, o que ooriginou um material de sonsist6encia semibranda que pode ser cortado com pá. 
PERFIL 12

C) ANÁLISES FISICAS E QUIMICAS

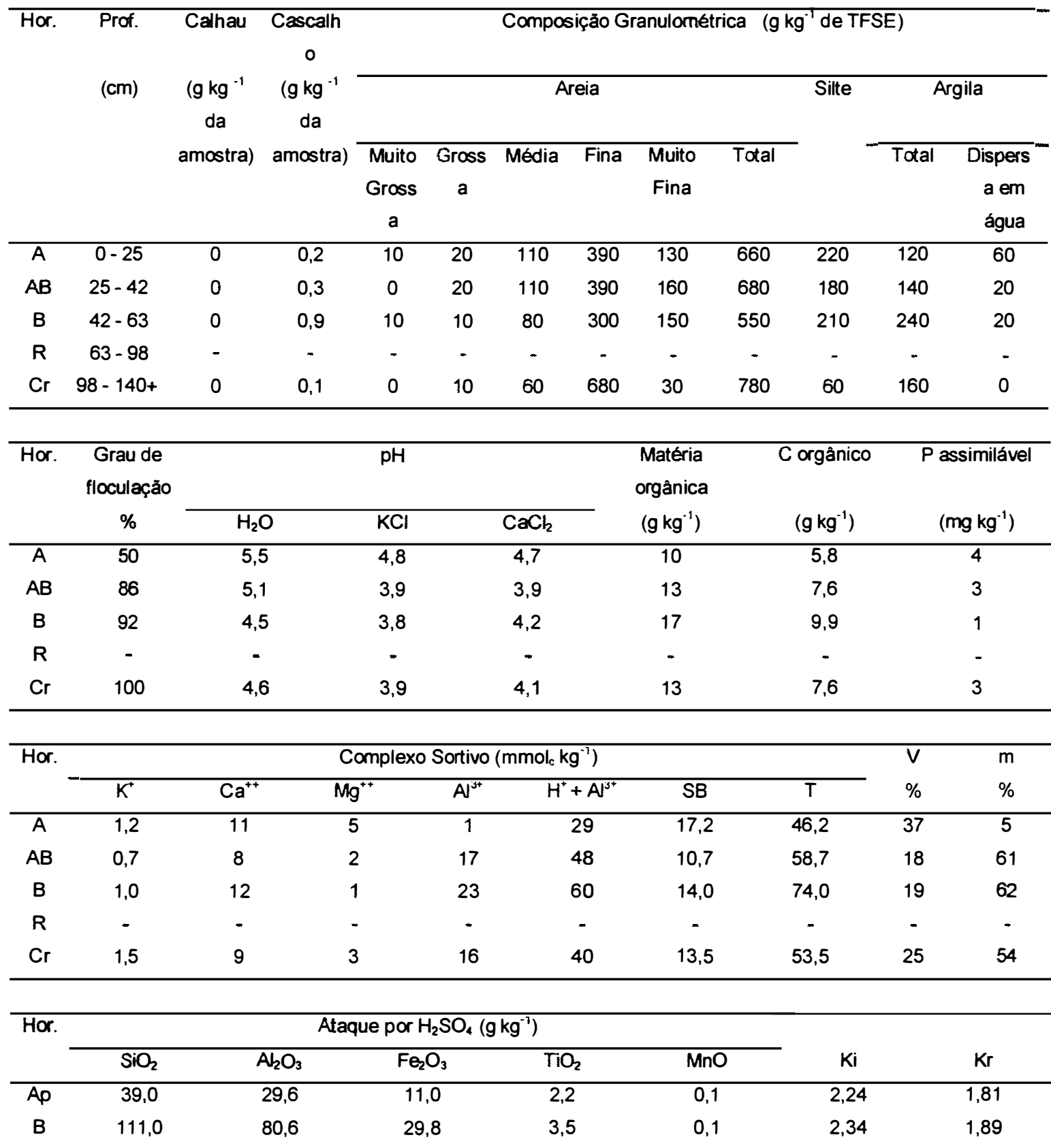

Análise granulométrica: calhau (>20 mm); cascalho ( $20-2 \mathrm{~mm})$; areia muito grossa (2 - $1 \mathrm{~mm})$; areia grossa ( 1 - 0,5 $\mathrm{mm})$; areia média $(0,5-0,25 \mathrm{~mm})$; areia fina $(0,25-0,10 \mathrm{~mm})$; areia muito fina $(0,10-0,05 \mathrm{~mm})$; silte $(0,05-0,002 \mathrm{~mm})$ argila total e dispersa em água $(<0,002 \mathrm{~mm})$ 


\section{A13 - Descrição e análises do Perfil 13}

A) DESCRIÇÃO GERAL :

CLASSIFICAÇĀO: ARGISSOLO VERMELHO Distrớico abrúptico

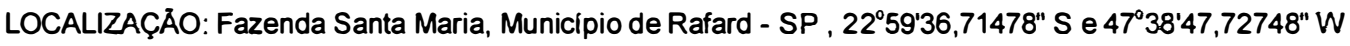

SITUAÇẢO, DECLIVE E COBERTURA VEGETAL SOBRE O PERFIL: terço inferior de encosta c0om declive de $8 \%$ sob cultura de cana-de-açúcar.

ALTITUDE: $\approx 495 \mathrm{~m}$

LITOLOGIA: rochas eruptivas básicas (diabásio)

MATERIAL ORIGINÁRIO: produtos de meteorização de diabásios com possivel contribuição de material coluvial

arenoso em superficie

RELEVO LOCAL: ondulado

RELEVO REGIONAL: ondulado

CLIMA: CWa

DESCRITO E COLETADO POR: Carlos Fernando Quartaroli

B) DESCRIÇĀO MORFOLÓGICA:

Ap $0-23 \mathrm{~cm} ; 3,7$ YR 3,6/1,6 úmido; 5,4 YR 4,3/2,4 seco; franco-argilo-arenoso; moderada, muuito pequena e pequena, blocos subangulares; ligeiramente duro, friável, plástico; ligeiramente pegajoso; transição abrupta e plana.

BA $23-46 \mathrm{~cm} ; 3,2$ YR 3,6/1,7 úmido; 4,9 YR 4,2/2,4 seco; franco-argilo-arenoso; moderada a forte; pequena e média, blocos subangulares; ligeiramente duro, friável, plástico e pegajoso; cerosidade fraca e comum; transiçåo clara e plana.

Bt1 46 - $71 \mathrm{~cm} ; 2,4$ YR 3.6/2,3 úmido; 3,8 YR 4,3/3,1 seco; muito argiloso; forte, média a grande, blocos subangulares (predominantes) e média a grande prismática; duro, muito firme, muito plástico e muito pegajoso; cerosidade forte e abundante; transição gradual e plana;

Bt2 71 - $150^{+} \mathrm{cm} ; 1,9$ YR 3,7/2,4 úmido; 3,3 YR 4,3/3,2 seco; muito argiloso; forte; grande, prismática (predominante) e grande e média blocos subangulares; muito duro, muito firme, muito plástico. muito pegajoso, cerosidade forte e abundante.

RAIZES: fasciculares de cana-de-açúcar, muitas em Ap, comuns em BA, raras em Bt1 eBt2, ocupando nestes apenas os espaços interagregados. 
PERFIL 13

C) ANÁLISES FISICAS E QUIMICAS

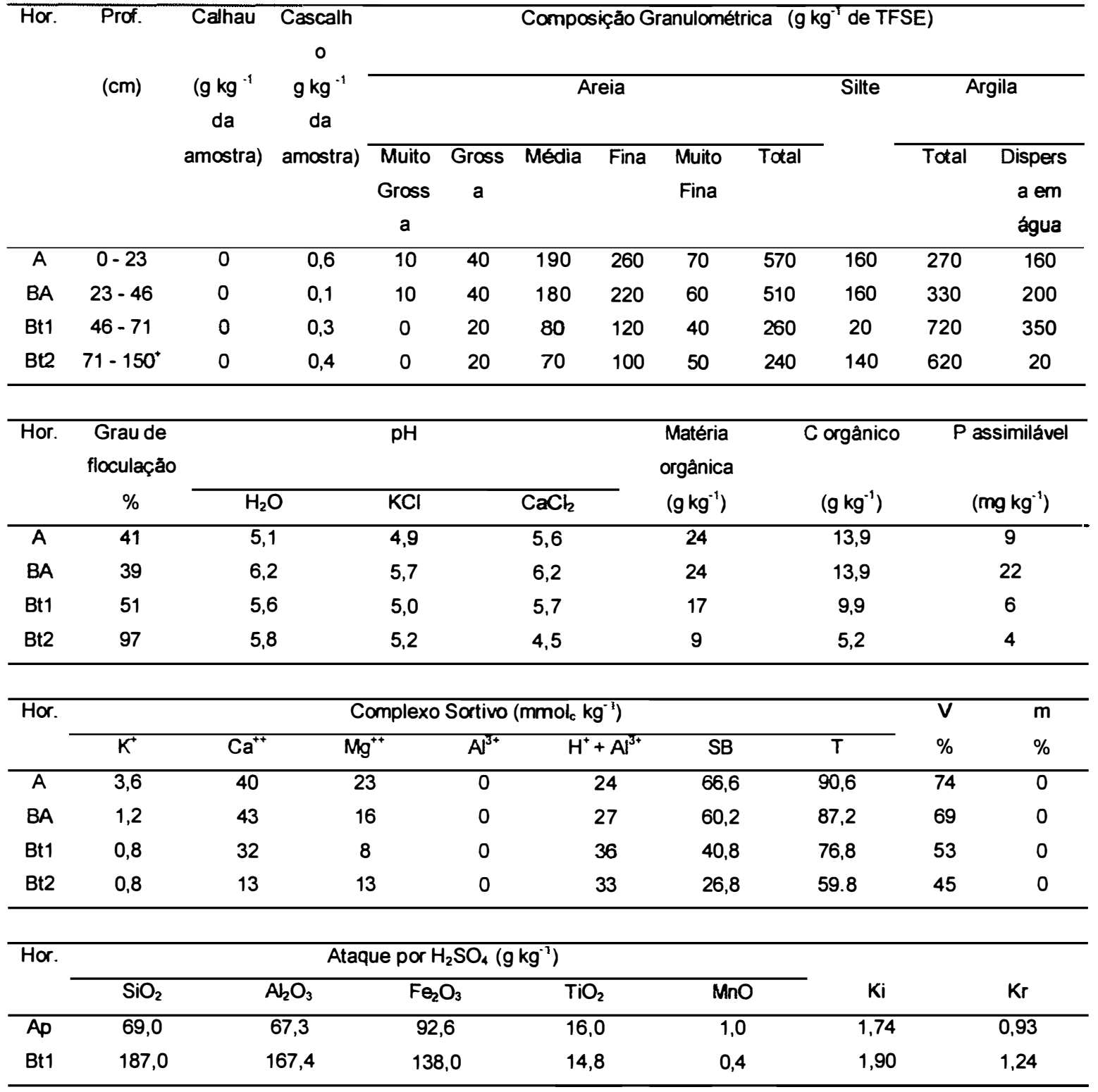

Análise granulométrica: calhau (>20 mm); cascalho ( 20 - $2 \mathrm{~mm})$; areia muito grossa (2 - $1 \mathrm{~mm})$; areia grossa (1 - 0,5 $\mathrm{mm})$; areia média $(0,5-0,25 \mathrm{~mm})$; areia fina $(0,25-0,10 \mathrm{~mm})$; areia muito fina $(0,10-0,05 \mathrm{~mm})$; silte $(0,05-0,002 \mathrm{~mm})$ argila total e dispersa em água $(<0,002 \mathrm{~mm})$ 


\title{
A14 - Descrição e análises do Perfil 14
}

\author{
A) DESCRIÇÃO GERAL : \\ CLASSIFICAÇÃO: NEOSSOLO REGOLITICO Distrófico típico

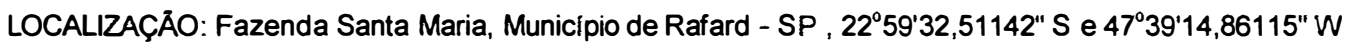 \\ de cana-de-açúcar. \\ ALTITUDE: $\approx 496 \mathrm{~m}$ \\ LITOLOGIA: arenitos com cimento argiloso \\ MATERIAL ORIGINÁRIO: produtos de meteorizaçảo de arenitos com cimento argiloso \\ RELEVO LOCAL: ondulado \\ RELEVO REGIONAL: ondulado \\ CLIMA: Cwa \\ DESCRITOE COLETADO POR: Carlos Fernando Quartaroli
}

SITUAÇẢO, DECLIVE E COBERTURA VEGETAL SOBRE O PERFIL: topo de encosta com declive de $3 \%$ sob cultura

B) DESCRIÇÃO MORFOLÓGICA:

Ap $\quad 0-32 \mathrm{~cm} ; 8,2$ YR 3,0/1,4 úmido; 9,2 YR 5,0/2,1 seco; areia franca; fraca, muito pequena e pequena, grumosa; macia, muito friável, nảo plástico e nảo pegajoso; transiçảo clara e descontínua.

$\mathrm{Bi} \quad 32$ - 77 cm; 6,2 YR 4,3/2,8 úmido; 7,1 YR 5,1/3,2 seco; areia franca; fraca, média a grande, granular; macia, muito friável, ligeiramenteplástico e nảo pegajoso, transiçảo clara e ondulada.

C $\quad 77-116 \mathrm{~cm} ; 4,8$ YR 4,4/3,3 úmido; 5,6 YR 5,1/3,9 seco; franco-argilo-arenoso, maciça, remoçảo do material do horizonte revela fragemntos rochosos alterados de arenito com cimento argiloso; forma de blocos angulares, grau de coesảo moderado a fraco, fragmentos com conssiténcia ligeiramente dura, friável, ligeiramente plástico e ligeiramente pegajoso; transiçāo plana e clara.

Cr 116 - 150+; 4,6 YR 4,4/3,5 úmido; 5,3 YR 4,8/3,6 seco; franco-argilo-arenoso; maciça, remoçảo do material do horizonte revela fragemntso rochosos alterados de arenito com cimento argiloso; forma de blocos angulares, grau de coesảo moderado a forte, fragmentos com conssiténcia dura, firme a friável, ligeiramente plástico e ligeiramente pegajoso.

RAIZZES: fasciculares de cana-de-açúcar, muitas em Ap, comuns em Bi, raras em $\mathrm{C}$ e $\mathrm{Cr}$, raízes e tubérculos de tiririca (Cyperus rotundus) em Ap.

\section{OBSERVAÇÓES:}

A transição de Ap para Bi é confusa. Há indícios de revolvimento do solo por práticas agrícolas o que teria provocado uma mistura dos horizontes $A$ e a parte superior de $B$, fazendo surgir dentro de $B$ porçỏes de solo com morfologia semelhjante ao A e vice-versa. Também a indícios de aplicaçảo de resíduos orgânicos da indústria sucroalcooleira, que pode ter contribuído para um maior escurecimento do horizonte $A$. 
C) ANÁLISES FISICAS E QUIMICAS

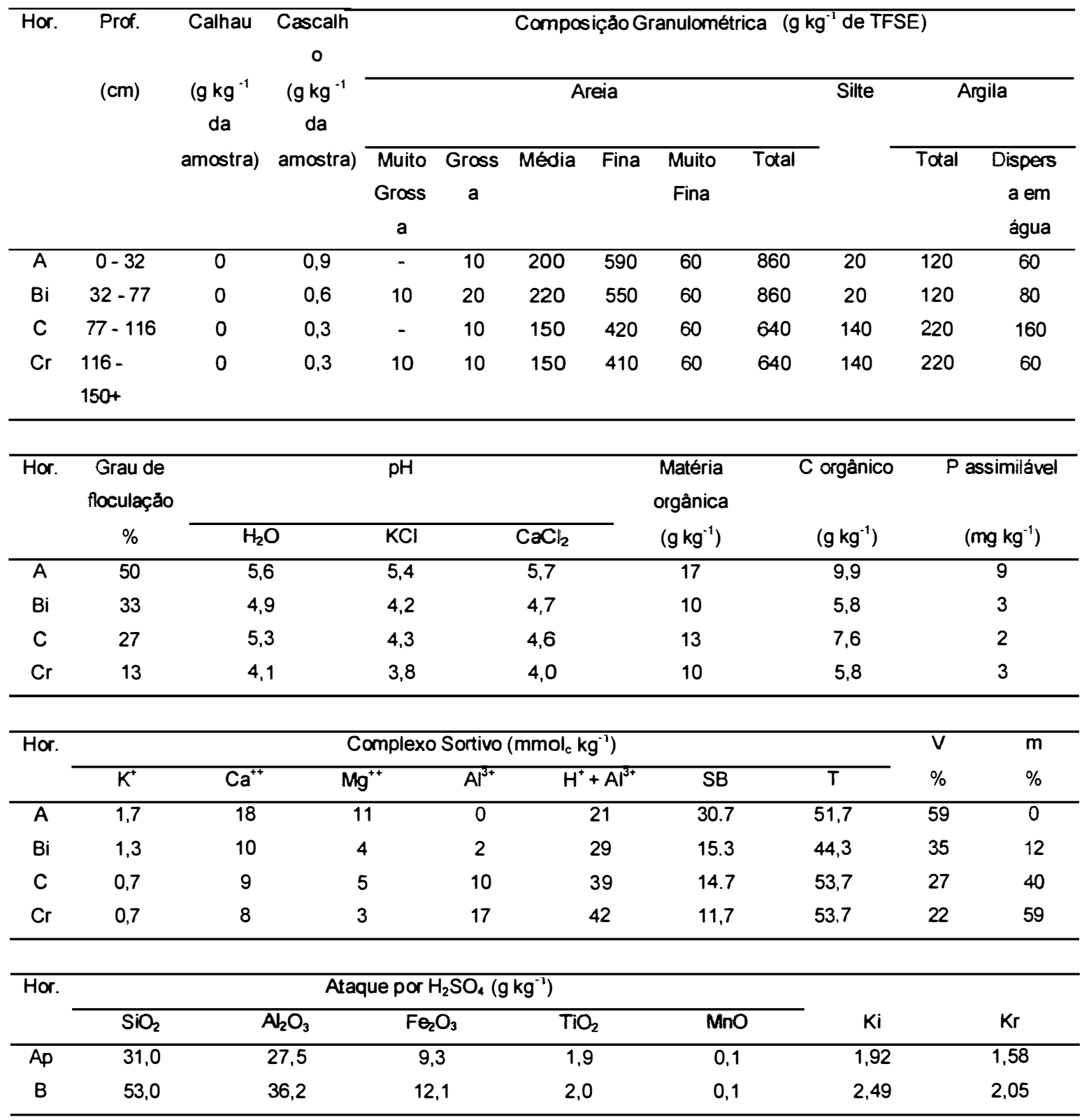

Análise granulométrica: calhau (>20 mm); cascalho ( $20-2 \mathrm{~mm})$; areia muito grossa (2 - $1 \mathrm{~mm})$; areia grossa (1 - 0,5 $\mathrm{mm})$; areia média $(0,5-0,25 \mathrm{~mm})$; areia fina $(0,25-0,10 \mathrm{~mm})$; areia muito fina $(0,10-0,05 \mathrm{~mm})$; silte $(0,05-0,002 \mathrm{~mm})$ argila total e dispersa em água $(<0,002 \mathrm{~mm})$ 


\section{A15 - Descrição e análises do Perfil 15}

A) DESCRIÇÃO GERAL :

CLASSIFICAÇĀO: CAMBBISSOLO HÁPLICO Tb Distrófico típico

LOCALIZAÇĀO: Fazenda Santa Maria, Municipio de Rafard - SP , 22059'46,96986" S e 47³8'56,65852" W

SITUAÇÃO, DECLIVE E COBERTURA VEGETAL SOBRE O PERFIL: terço superior de encosta com $5 \%$ de declive sob cultura de cana-de-açúcar.

ALTITUDE: $\approx 526 \mathrm{~m}$

LITOLOGIA: arenitos com cimento argiloso

MATERIAL ORIGINÁRIO: produtos da meteorização de arenitos com cimento argiloso

RELEVO LOCAL: ondulado

RELEVO REGIONAL: ondulado

CLIMA: CWa

DESCRITO E COLETADO POR: Carios Femando Quartaroli

\section{B) DESCRIÇÃO MORFOLÓGICA:}

Ap $\quad 0$ - $22 \mathrm{~cm} ; 7,2$ YR 4,0/1,7 úmido; 8,5 YR 5,2/2,3 seco; franco-arenoso; fraca, muito pequena e pequena, grumosa; macia, muito friável, não plástico e não pegajoso; transição abrupta e ondulada.

Bi 22 - 42 cm; 6,2 YR 4,4/2,7 úmido; 7,5 YR 5,7/3,2 seco; franco-arenoso; fraca, média a grande, granular; macia, muito friável, ligeiramente plástico e nảo pegajoso, transição clara e ondulada.

C $\quad 42-70 \mathrm{~cm} ; 5,3$ YR 4,4/3,2 úmido; 6,8 YR 5,5/3.7 seco; franco-argilo-arenoso, maciça, remoção do material do horizonte revela fragemntos rochosos alterados de arenito com cimento argiloso; forma de blocos angulares, grau de coesảo moderado a fraco, fragmentos com conssiténcia ligeiramente dura, friável, ligeiramente plástico e ligeiramente pegajoso; transiçảo plana e clara.

$\mathrm{Cr} \quad 70$ - 144t; 4,9 YR 4,4/3,2 úmido; 6,4 YR 5,2/3,5 seco; argila arenosa; maciça, remoção do material do horizonte revela fragemntso rochosos alterados de arenito com cimento argiloso; forma de blocos angulares, grau de coesão moderado a forte, fragmentos com conssiténcia dura, firme a friável, ligeiramente plástico e ligeiramente pegajoso.

RAIZES: fasciculares de cana-de-açúcar, muitas em Ap, comuns em Bi, raras em $\mathrm{C}$ e $\mathrm{Cr}$. 
C) ANÁLISES FISICAS E QUIMICAS

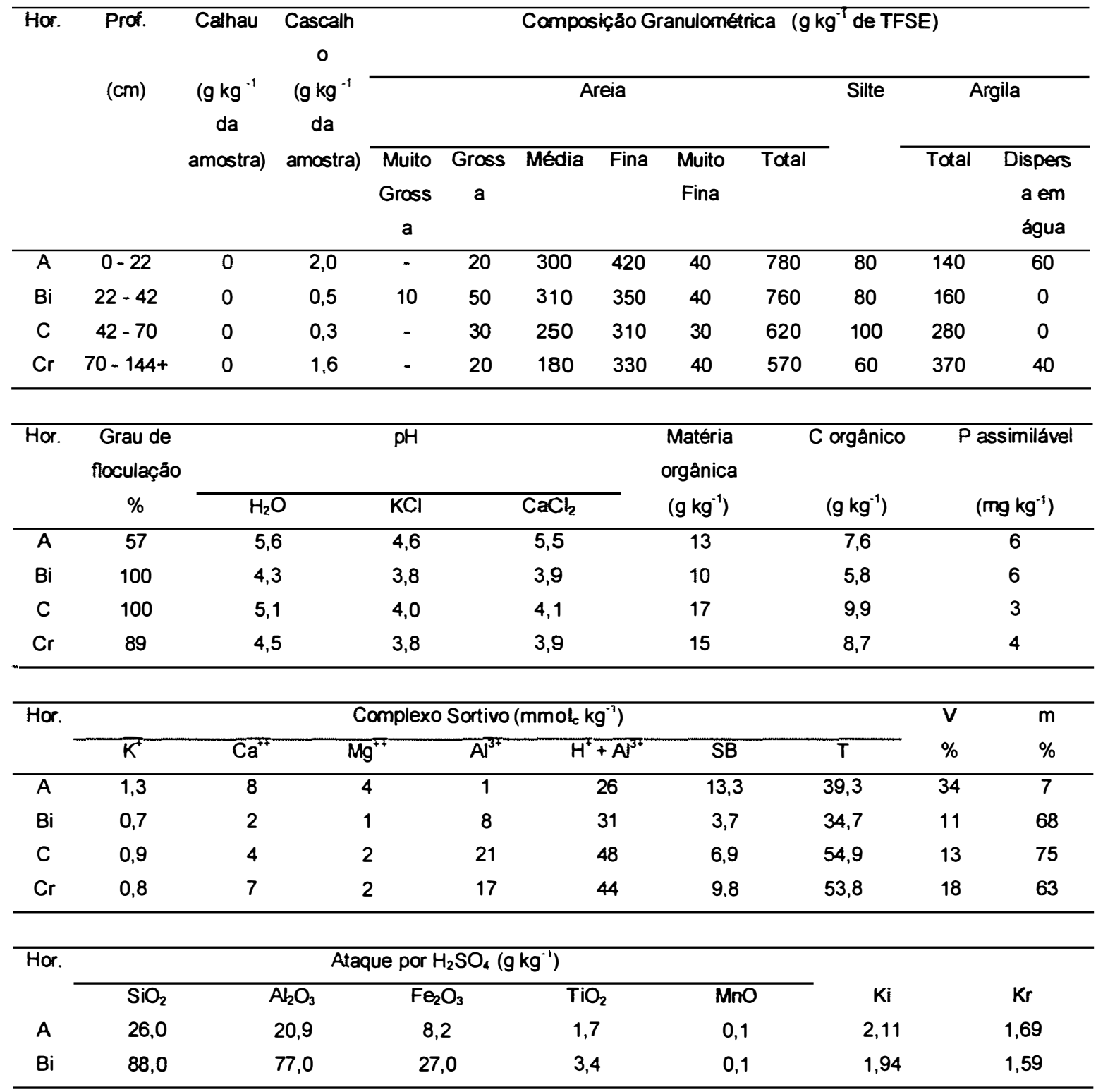

Análise granulométrica: calhau (>20 mm); cascalho ( 20 - $2 \mathrm{~mm})$; areia muito grossa (2 - $1 \mathrm{~mm})$; areia grossa (1 - 0,5 $\mathrm{mm})$; areia média $(0,5-0,25 \mathrm{~mm})$; areia fina $(0,25-0,10 \mathrm{~mm})$; areia muito fina $(0,10-0,05 \mathrm{~mm})$; silte $(0,05-0,002 \mathrm{~mm})$ argila total e dispersa em água $(<0,002 \mathrm{~mm})$ 


\section{A16- Descrị̧ão e análises do Perfil 16}

A) DESCRIÇÃO GERAL :

CLASSIFICAÇÃO: NITOSSOLO VERMELHO Eutroférrico latossólico

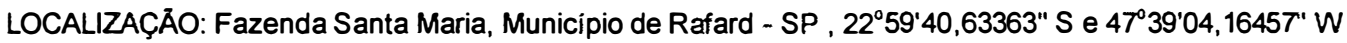

SITUAÇÃO, DECLIVE E COBERTURA VEGETAL SOBRE O PERFIL: terço superior de encosta com $8 \%$ de declive sob cultura de cana-de-açúcar.

ALTITUDE: $\approx 513 \mathrm{~m}$

LITOLOGIA: rochas eruptivas básicas (diabásios)

MATERIAL ORIGINARIO: produto da meteorizaçăo de diabásios

RELEVO LOCAL: ondulado

RELEVO REGIONAL: ondulado

CLIMA: Cwa

DESCRITO E COLETADO POR: Carlos Fernando Quartaroli

\section{B) DESCRIÇĀO MORFOLÓGICA:}

Ap $\quad 0-30 \mathrm{~cm} ; 2,0$ YR 3,6/1,9 úmido; 3,4 YR 4,2/2,9 seco; argila; forte média a grande blocos subangulares que se desfazem em forte pequena a muito pequena blocos subangulares e muito pequena granular; duro, firme, muito plástico e muito pegjoso; cerosidade moderada e comum; transiçăo gradual e plana.

Bt $\quad 30$ - $95 \mathrm{~cm} ; 1,1$ YR 3,6/1,9 úmido; 2,5 YR 4,2/3,3 seco; muito argilosa; forte grande blocos subangulares; dura a muito dura, firme a muito firme, muito plástico e muito pegajoso; cerosidade forte e abundante; transiçảo gradual e plana.

Bw $\quad 95-150^{+} \mathrm{cm} ; 1,3$ YR 3,7/2,5 úmido; 2,3 yr 4,0/2,8 seco; maciça porosa que se desfaz em forte muito pequena granular; macio, muito friável; muito plástico e muito pegajoso; cerosidade fraca e pouca.

RAIZZES: fasciculares de cana-de-açúcar com diâmetros inferiores a $3 \mathrm{~mm}$; raízes pivotantes de caruru (Amaranthus sp.), ambas abundantes em Ap, raras em Bt e Bw. 
C) ANÁLISES FISICAS E QUIMICAS

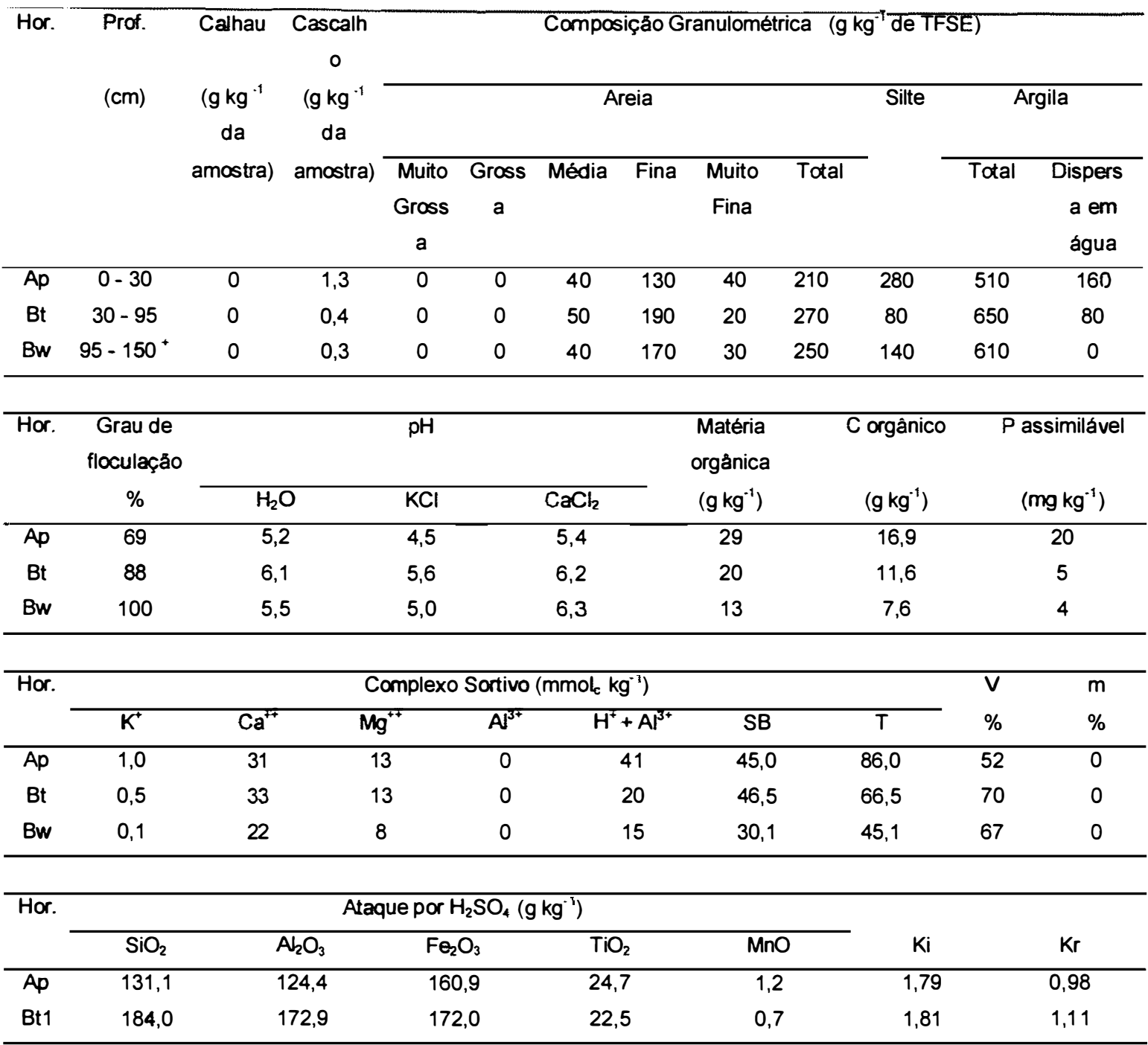

Análise granulométrica: calhau (>20 mm); cascalho ( 20 - $2 \mathrm{~mm}$ ); areia muito grossa (2 - $1 \mathrm{~mm})$; areia grossa (1 - 0,5 $\mathrm{mm})$; areia média $(0,5-0,25 \mathrm{~mm})$; areia fina $(0,25-0,10 \mathrm{~mm})$; areia muito fina $(0,10-0,05 \mathrm{~mm})$; silte $(0,05-0,002 \mathrm{~mm})$ argila total e dispersa em água $(<0,002 \mathrm{~mm})$ 


\title{
A17 - Descrição e análises do Perfil 17
}

\begin{abstract}
A) DESCRIÇÃO GERAL :
CLASSIFICAÇĀO: ARGISSOLO AMARELO Eutrớfico abrúptico
\end{abstract}

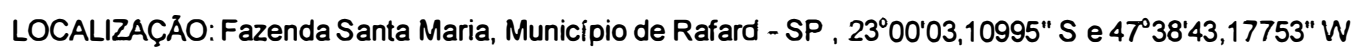

SITUAÇẢO, DECLIVE E COBERTURA VEGETAL SOBRE O PERFIL: topo de encosta com $3 \%$ de declive sob cultura de cana-de-açúcar

ALTITUDE: $\approx 552 \mathrm{~m}$

LITOLOGIA: arenitos com cimento argiloso

MATERIAL ORIGINARIO: produto de meteorizaçāo de arenitos com cimento argiloso

RELEVO LOCAL: Ondulado

RELEVO REGIONAL: ondulado

CLIMA: CWa

DESCRITO E COLETADO POR: Carlos Femando Quartaroli

\section{B) DESCRIÇÃO MORFOLÓGICA:}

Ap $\quad 0$ - $36 \mathrm{~cm} ; 9,0$ YR 3,0/1,3 úmido; 10,0 YR 5,4/1,9 seco; franco-arenoso; fraca. pequena granular; macio, solto, nảo plástico e nảo pegajoso; transiçảo abrupta e ondulada.

E $\quad 36-50 \mathrm{~cm} ; 8,0$ YR 4,9/2,7 úmido; 9,2 YR 6,5/2,8 seco; franco-arenoso; fraca pequena granular, macio, solto, nảo plástico, nảo pegajoso; transiçảo abrupta e irregular.

B $\quad 50-110 \mathrm{~cm} ; 6,1$ YR 4,4/3,0 úmido; 7,3 YR 5,5/3,5 seco; mosqueado comum, médio e distinto (10 YR 5/4 úmido e 5 YR 4/6 úmido); franco-argilo-arenoso; moderada média blocos subangualres; plástico e pegajoso.

RAIZES: fasciculares de cana-de-açúcar e tiririca (Cyperus rotundus), muitas em Ap, raras em E, ausentes em B; tubérculos de tiririca em Ap. 
C) ANÁLISES FISICAS E QUIMICAS

\begin{tabular}{|c|c|c|c|c|c|c|c|c|c|c|c|c|}
\hline \multirow[t]{3}{*}{ Hor. } & \multirow{3}{*}{$\begin{array}{l}\text { Prof. } \\
\text { (cm) }\end{array}$} & \multirow[b]{3}{*}{$\begin{array}{c}\text { Calhau } \\
\mathrm{g} \mathrm{kg}^{-1} \\
\text { da } \\
\text { amostr } \\
\text { a }\end{array}$} & \multirow{3}{*}{$\begin{array}{c}\text { Cascalho } \\
\mathrm{g} \mathrm{kg}^{-1} \mathrm{da} \\
\text { amostra }\end{array}$} & \multicolumn{9}{|c|}{ Composição Granulométrica $\left(\mathrm{g} \mathrm{kg}^{-1}\right.$ de TFSE) } \\
\hline & & & & \multicolumn{6}{|c|}{ Areia } & \multirow[t]{2}{*}{ Silte } & \multicolumn{2}{|c|}{ Argila } \\
\hline & & & & $\begin{array}{c}\text { Muito } \\
\text { Gross } \\
\text { a }\end{array}$ & $\begin{array}{c}\text { Gross } \\
\text { a }\end{array}$ & Média & Fina & $\begin{array}{l}\text { Muito } \\
\text { Fina }\end{array}$ & Total & & Total & $\begin{array}{c}\text { Dispers } \\
\text { a em } \\
\text { água }\end{array}$ \\
\hline Ap & $0-36$ & 0 & 1,3 & 10 & 40 & 260 & 380 & 50 & 740 & 140 & 120 & 60 \\
\hline$E$ & $36-50$ & 0 & 1,5 & 10 & 30 & 200 & 340 & 160 & 740 & 140 & 120 & 40 \\
\hline Bt & $50-110^{+}$ & 0 & 1,2 & 10 & 20 & 160 & 320 & 70 & 580 & 160 & 260 & 180 \\
\hline \multirow[t]{3}{*}{ Hor. } & Grau de & & \multirow{2}{*}{\multicolumn{2}{|c|}{$\mathrm{pH}$}} & & & \multirow{2}{*}{\multicolumn{2}{|c|}{$\begin{array}{l}\text { Matéria } \\
\text { orgånica }\end{array}$}} & \multirow[t]{2}{*}{ C orgånico } & \multirow{2}{*}{\multicolumn{2}{|c|}{ P assimilável }} \\
\hline & floculaçāo & & & & & & & & & & & \\
\hline & $\%$ & \multicolumn{2}{|c|}{$\mathrm{H}_{2} \mathrm{O}$} & \multicolumn{2}{|l|}{$\mathrm{KCl}$} & \multicolumn{2}{|l|}{$\mathrm{CaCl}_{2}$} & $\mathrm{~g} \mathrm{~kg}^{-1}$ & & $\mathrm{~g} \mathrm{~kg}^{-1}$ & \multicolumn{2}{|c|}{$m g ~ k g^{-1}$} \\
\hline Ap & 50 & \multicolumn{2}{|c|}{6,0} & \multicolumn{2}{|l|}{5,9} & \multicolumn{2}{|l|}{5,4} & \multicolumn{2}{|l|}{15} & 8,7 & \multicolumn{2}{|r|}{17} \\
\hline$E$ & 67 & \multicolumn{2}{|c|}{5,5} & \multicolumn{2}{|l|}{5,1} & \multicolumn{2}{|l|}{4,7} & 9 & & 5,2 & \multicolumn{2}{|r|}{3} \\
\hline$B t$ & 31 & \multicolumn{2}{|c|}{5,5} & \multicolumn{2}{|l|}{4,7} & 5,4 & & 15 & & 8,7 & & 2 \\
\hline Hor. & & & & omplexo & Sortivo & $\left(\mathrm{mmol}_{\mathrm{c}} \mathrm{h}\right.$ & $\left.g^{-7}\right)$ & & & & $\mathbf{V}$ & $m$ \\
\hline & $K^{+}$ & $\mathrm{Ca}^{+}$ & & & $\mathrm{Al}^{3+}$ & & $+\mathrm{Al}^{3+}$ & SB & & $\bar{T}$ & $\%$ & $\%$ \\
\hline$A p$ & 2,5 & 33 & & & 0 & & 16 & $46 ., 5$ & & 62,5 & 74 & 0 \\
\hline$E$ & 0,4 & 1 & & & 0 & & 13 & 4,4 & & 17,4 & 25 & 0 \\
\hline Bt & 1,0 & 20 & & 3 & 1 & & 22 & 27,0 & & 49,0 & 55 & 4 \\
\hline Hor. & & & Ata & jue por & $\mathrm{H}_{2} \mathrm{SO}_{4}(\mathrm{c}$ & $\left.\mathrm{kg}^{-7}\right)$ & & & & & & \\
\hline & $\mathrm{SiO}_{2}$ & & $\mathrm{Al}_{2} \mathrm{O}_{3}$ & $\mathrm{Fe}$ & & $\mathrm{TiC}$ & & $\mathrm{MnO}$ & & $\mathrm{Ki}$ & & $\mathrm{Kr}$ \\
\hline$A p$ & 33,0 & & 21,9 & 6 & & 1, & & 0,2 & & 2,56 & & 2,17 \\
\hline Bt & 81,0 & & 73,4 & 21 & & 2, & & 0,1 & & 1,88 & & 1,58 \\
\hline
\end{tabular}

Análise granulométrica: calhau (>20 mm); cascalho ( $20-2 \mathrm{~mm})$; areia muito grossa $(2-1 \mathrm{~mm})$; areia grossa (1 - 0,5 $\mathrm{mm})$; areia média $(0,5-0,25 \mathrm{~mm})$; areia fina $(0,25-0,10 \mathrm{~mm})$; areia muito fina $(0,10-0,05 \mathrm{~mm})$; silte $(0,05-0,002 \mathrm{~mm})$ argila total e dispersa em água $(<0,002 \mathrm{~mm})$ 


\section{REFERÊNCIAS BIBLIOGRÁFICAS}

AL-ABBAS, A.H.; SWAIN, P.H.; BAUMGARDNER, M.F. Relating organic matter and clay content to multispectral radiance of soils. Soil Science, Baltimore, 114(6): 477$85,1972$.

ALMEIDA, F. F. M.; MELO, M. S. A bacia do Paraná e o vulcanismo mesozóico. In: ALMEIDA, F. F. M.; HASUI, Y.; PONÇANO, W. L.; DANTAS, A. S. L.; CARNEIRO, C. D. R.; MELO, M. S.; BISTRICHI, C. A. Mapa geológico do Estado de São Paulo. São Paulo: IPT, 1981. cap. 4, p. 46 - 81.

ANDRONIKOV, V.L.; DOBROLV'SKIY, G.V. Theory and methods for the use of remote sensing in the study of soils. Mapping Sciences \& Remote Sensing, v.28, n.2, p.92-101, 1991.

BAPTISTA, G. M. M.; MARTINS, E. S.; MADEIRA NETO, J. S.; CARVALHO JUNIOR. O. A.; MENESES, P. R. Use of AVIRIS data for mineralogical mapping in tropical soils, in the district of São João D'aliança, Goiás. Proceedings of the seventh Airborne Visible/Infrared Imaging Spectrometer (AVIRIS) Workshop. JPL Publications 97-21, vol. 1, p. 33-42, 1998.

BAUMGARDNER, M. F.; SILVA, L. F.; BIEHL, L. L.; STONER, E. R. Reflectances properties of soils. Advances in Agronomy, v.38, p.1-44, 1985.

BAUMGARDNER, M.F.; KRISTOF, S.J.; JOANNSEN, C.J.; ZACHARY, A.L. Effects of organic matter on the multiespectral properties of soils. Proceedings. Indiana Academy of Science, Brookville, 79: 413-22, 1970.

BECK, R.H.; ROBINSON, B.F.; MCFEE, W.H.; PETERSON, J.B. Spectral characteristics of soils related to the interaction of soil moisture, organic carbon 
and clay content. West Lafayette, Purdue University, 1976. (LARS Information Note, 081176).

BEDIDI, A.; CERVELLE, B. Mesures spectrophotométriques de laboratorie. Photo Interpretation, v.34, p. 9-27, 1996.

BEN-DOR, E.; IRONS, J.R.; EPEMA, G.F. Soil reflectance, In: Remote sensing for the Earth Sciences, Manual of remote sensing, Andrew N. Renaz, third Edition, v.3, p.111-188, 1999.

BISWAS, R. R.; A soil map through Landsat satellite imagery in a part of the Auranga catchment in tehe Ranchi and Palamou districts of Bihar, India. International Journal of Remote Sensing, v.8, p.541-543, 1987.

BOLUDA, R.; COLOMER, J.C.; MORELL, C. SÁNCHEZ, J. Estudio de las curvas de reflectividad y su relacion con las propiedades de los suelos en zona semiarida (Castilla-la Mancha, España). In: Congresso Iberoamericano de la Ciência del Suelo. Salamanca, España, Sep., 1993. p. 1-8.

BOWERS, S.A. \& HANKS, R.J. Reflectance of radiant energy from soils. Soil Science, Baltimore, 100(2): 130-8, 1965.

BURING, P. The aplications of aerial photographs in soil surveys. In: Manual of photographic interpretation. Washington: American Society of Photogrammetry, 1960. cap 11, p.633-666.

CAMARGO, O.A.de; MONIZ, A.C.; JORGE, J.A.; VALADARES, J.M. Métodos de análise química, mineralógica e física de solos do IAC. Campinas, Instituto Agronômico de Campinas, 1986, 94 p. (IAC. Boletim Técnico, 106).

CARVALHO, A. A study of Terra Roxa Estruturada and Latosol Roxo on a topographic sequence in São Paulo State, Brasil. Upon Tyne, New Castle, England, 1972 (M.S. University of New Castle).

CIPRA, J.E.; SWAIN, P.H.; GILL, J.H.; BAUMGARDNER, M.F.; KRISTOF, S.J. Definition of spectrally separable classes for soil survey research. West Lafayette, Purdue University, 1972. (LARS Technical Report, 100372). 
CLARK, R. N. Spectroscopy of rocks and minerals, and principles of spectroscopy. In: Manual of Remote Sensing, Rencz, A. N. (ed.). Remote sensing for the Earth Science. John Wiley and Sons, New York, vol. 3, 1999.

CLARK, R. N.; GALLAGHER, A. J.; SWAYZE, G. A. Material absorption band depth mapping of imaging spectrometer data using a complete band shape leastsquares fit with library reference spectra. Summaries of the Thrird Airbome Visible/Infrared Imaging Spectrometer (AVIRIS) Workshop. JPL Publications 9054, p. 176-186, 1990.

COLEMAN, T.L. \& MONTGOMERY, O.L. Soil moisture, organic matter, and iron content effect on the spectral characteristics of selected Vertisols and Alfisols in Alabama. Photogrammetric Engineering, and Remote Sensing, Falls Church, 53(12): 1659-63, Dec. 1987.

COLEMAN, T.L.; AGBU, P.A.; MONTGOMERY, O.L.; GAO,T.; PRASAD, S. Spectral band selection for quantifying selected properties in highly weathered soils. Soil Science, Baltimore, 151: 355-61, 1991.

CONDIT, H.R. The spectral reflectance of American Soils. Photogrammetric Engineering, Falls Church, 36: 955-66, 1970.

COMISSÃO DE SOLOS. Ministério da Agricultura. Centro Nacional de Ensino e Pesquisa Agronômica. Levantamento de reconhecimento de solos do Estado de São Paulo. Rio de Janeiro, 1960. 634 p. (SNPA. Boletim, 12).

COSTA, L.M. Surface soil color and reflectance as related to physico-chemical and mineralogical soil properties. Columbia, 1979. 154p. (PhD - University of Missouri).

COURAULT, D.; GIRARD, M.C. Relationships between the soil composition and their spectral signature. In: SYMPOSIUM OF THE WORKING GROUP REMOTE SENSING, 5, Budapest, 1988. Proceedings. Budapest, 1988. p. 1 78-185.

CRUICKSHANK, M. M.; TOMLINSON, R. W. An assessment of the potential of SPOT reflectance data for soil survey in Northern Ireland. Proceedings Royal Irish Academy, v.88b, p.45-60, 1988.

CSRIO. Division of Exploration and manin, the. ARIES-1 Applications Development Program (ADP). http://aries@dem.csiro.au Dec. 1997. 
DALMOLIN, R.S.D., Faltam pedólogos no Brasil, Boletim Informativo SBCS, Viçosa, v.24, n.4, p.13-15, 1999.

DEMATTÊ, J. A. M.; DEMATTÊ, J. L.; CAMARGO, W. P.; FIORIO, P. R.; NANNI, M.R. Remote sensing in the recognition and mapping of tropical soils developed on topographic sequences. Mapping Sciences \& Remote Sensing. v.38, n.2, p. 79-102, 2001.

DEMATTÊ, J.A. M.; COOPER, M.; MAULE, R. F.; FIORIO, P. R. Caracterization des sols dans une toposéquence sun diabase atravers la réflectance spectrale. (compact disc) In: CONGRES MONDIAL DE SCIENCE DU SOL, Montpellier, France, 1998b.

DEMATTÊ, J. A. M. Relações entre dados espectrais e características físicas, químicas e mineralógicas de solos desenvolvidos de rochas eruptivas. Piracicaba, 1995. 265 p. Tese (Doutorado) - Escola Superior de Agricultura Luiz de Queiroz, Universidade de São Paulo.

DEMATTÊ, J. A. M. HUETE, A. R. FERREIRA Jr., L. G.; ALVES, M. C.; NANNI, M. R.; CERRI, C. E. Evaluation of tropical soils through ground and orbital sensors. In: INTERNATIONAL CONFERENCE ON GEOSPATIAL INFORMATION IN AGRICULTURE AND FORESTRY, 2., Florida, 10-12 January, 2000. Proceedings, ERIM, p.34-41, v.2, 2000.

DEMATTÊ, J. A. M. Reflectância espectral de solos. Piracicaba, 1999. 452p. Tese (Livre Docência) - Escola Superior de Agricultura Luiz de Queiroz, Universidade de São Paulo.

DEMATTÊ, J. A. M.; CAMPOS, R. C.; ALVES, M. C. Evaluation of soil survey by spectral reflectance. In: APPLIED GEOLOGIC REMOTTE SENSING THIRTEENTH INTERNATIONAL CONFERENCE, 13., Vancouver, BC, Canada, 1-3 March, 1999. Proceedings, ERIM, p.126-133, v.2, 1999.

DEMATTÊ, J. A. M.; FOCHT, D. Detecção de solos erodidos pela avaliação de dados espectrais. Revista Brasileira de Ciência do Solo, v.23, n.2, p.401-413, 1999. 
DEMATTÊ, J. A. M.; GARCIA, G. J. Alteration of soil properties through a weathering sequence as evaluated by spectral reflectance. Soil Science Society of America Journal, v.63, v2, p.327-342, 1999.

DEMATTÊ, J. A. M.; SOUSA, A. A.; NANNI, M. R. Avaliação espectral de amostras de solo e argilo-minerais em função de diferentes níveis de hidratação (Compact Disc). In: SIMPÓSIO BRASILEIRO DE SENSORIAMENTO REMOTO, 9., Santos, 1998. Anais. Santos: INPE/SELPER, 1998a.

DEMATTÊ, J. A.M.; DEMÉTRIO, V. A. Fotointerpretação de padrões de drenagem em amostras circulares na caracterização de solos basálticos do Estado do Paraná. Revista Brasileira de Ciência do Solo, v.20, p.109-115, 1996.

DEMATTÊ, J.A.M. O pedólogo e a agricultura de precisão. Sociedade Brasileira de Ciência do Solo, Boletim Informativo, v.26, n.1, p.17-18, 2001

DEMATTÊ, J. L.; MARCONI, A. A drenagem na mineralogia de solos desenvolvidos de diabásio em Piracicaba (SP). Revista Brasileira de Ciência do solo, v.15, p.1-8, 1991.

DONZELI, P.L. Comportamento espectral de três latossolos argilosos da região de Limeira - Araras - SP em relação às suas propriedades fisicas e químicas. Piracicaba, 1984. 149 p. (Doutorado - Escola Superior de Agricultura "Luiz de Queiroz"/USP).

EMBRAPA. Centro Nacional de Pesquisa de Solos. Sistema brasileiro de classificação de solos. Brasília: Serviço de Produção. 1999. 412 p.

EMBRAPA. CNPS. Manual de métodos de análise de solo. Rio de Janeiro, 1997. 212p.

EMBRAPA. SNLCS. Critérios para distinção de classes de solos e de fases de unidades de mapeamento; normas em uso pelo SNLCS. Rio de Janeiro, 1989. $67 \mathrm{p}$.

EPIPHÂNIO, J.C.N. Bandas termal e refletidas do TM-LANDSAT-5 no estudo do comportamento espectral de três Latossolos. In: CONGRESSO BRASILEIRO DE CIÊNCIA DO SOLO, 21. Anais. Campinas, SBCS, 1987. p. 65.

EPIPHANIO, J.C.N.; FORMAGGIO, A.R. abordagens de uso de número digital e de reflectância em sensoriamento remoto com dados de satélites. Simpósio Brasileiro de Sensoriamento Remoto, 5., Natal, 1988. Anais. São José dos Campos: INPE, p. 131. 
EPIPHANIO, J.C.N.; FORMAGGIO, A.R.; VALERIANO, M.M.; OLIVEIRA, J.B. Comportamento espectral de solos do Estado de São Paulo. São José dos Campos, Instituto Nacional de Pesquisas Espaciais, 1992. 131 p.

FORMAGGIO, A. R.; EPIPHANIO, J. C. N.; VALERIANO, M. M.; OLIVEIRA, J. B. Comportamento espectral (450-2.450 nm) de solos tropicais de São Paulo. Revista Brasileira de Ciência do Solo, Campinas, v.20, p.467-474, 1996.

FORMAGGIO, A.R. Comportamento espectral de quatro solos do Estado de São Paulo nos níveis orbital, de campo e de laboratório. São José dos Campos, 1983. 90 p. (Mestrado - Instituto Nacional de Pesquisas Espaciais).

FRANÇA, G.V. Interpretação fotográfica de bacias e de redes de drenagem aplicada a solos da região de Piracicaba. Piracicaba, 1968. 151 p. (Doutorado - Escola Superior de Agricultura "Luiz de Queiroz"/USP).

GALV ÃO, L. S.; VITORELLO, I. Variability of laboratory measured soil lines of soil from southeastern Brazil. Remote Sensing of Environment, v.6, n.2, p.166-181, 1998.

GALVÃO, L. S.; VITORELLO, I.; FORMAGGIO, A.R. Relationships of spectral reflectance and color among surface and subsurface horizons of tropical soil profíles. Remote Sensing of Environment, v.61, p.24-33, 1997.

GALVÃO, L.; VITORELLO, Í.; PARADELLA, W. Spectrodadiometric discrimination of laterites with pricipal components analysis and additive modeling. Remote Sensing of Environment, v.53, p.70-75, 1995.

GER, 1996. Geophysical Environmental Research Corp. Mark V dual gild of View Iris Manual. Version 1.3. Produced and published in Milbook, New York, 63 p.

GUPTA, R. P. Remote sensing geology. New York: Springer-Verlag Berlin, 1991. cap. 13, p. 223-263: Geological applications.

HAUFF, P.L.; KRUSE, F.A.; THIRY, M. Spectral identifications and characteristics of kaolinite/smectite clay in weathering environments. In: AUSTRALIAN REMOTE SENSING CONFERENCE, 5. Perth, Australia, 8-12 Oct., 1990. p. 898-905. 
HENDERSON, T.L.; BAUMGARDNER, M.F.; FRANZMEIER, D.P.; STOTT, D.E.; COSTER, D.C. High dimensional reflectance analysis of soil organic matter. Soil Science Society of America Journal, Madison, 56(3): 865-72, 1992.

HUETE, A. R. Extension of soil spectra to the satellite: atmosphere, geometric, and sensor considerations. Photo Interpretation, v.34, p.101-114, 1996.

HUETE, A.R., JUSTICE, C.; LIU, H. Development of vegetation and soil indices for MODIS-EOS. Remote sensing environment, 49: 224-234, 1994.

HUNT, G. R.; SALISBURY, J. W.; LENHOFF, C. J. Visible and near-infrared spectra of minerals and rocks: I. Oxides and hydroxides. Modern Geology, v.2, p.195-205, 1971.

HUNT, G.R. \& SALISBURY, J.W. Visible and infrared spectra of minerals and rocks: II. Carbona. Modern Geology, New York, 2: 23-30. 1970.

INSTITUTO BRASILEIRO DE GEOGRAFIA E ESTATÍSTICA. IBGE. Mapa planialtimétrico. Rio de Janeiro, 1970. Folha SF-23-Y-A-IV-2 (Capivari), Escala $1: 50.000$.

INSTITUTO BRASILEIRO DE GEOGRAFIA E ESTATÍSTICA. IBGE. Mapa planialtimétrico. Rio de Janeiro, 1970. Folha SF-23-Y-A-IV-4 (Porto Feliz), Escala $1: 50.000$.

INSTITUTO DE PESQUISAS TECNOLÓGICAS. IPT. Divisão de Minas e Geologia Aplicada. Mapa geológico do Estado de São Paulo. São Paulo, 1981. Escala $1: 1000.000$.

INSTITUTO NACIONAL DE PESQUISAS ESPACIAIS, INPE. Tutorial Spring: spring básico. São José dos Campos: INPE. 1999. não paginado.

KOSMAS, C.S.; CURI, N.; BRYANT, R.B.; FRANZMEIER, D.P. Characterization of iron oxide minerals by second-derivative visible spectroscopy. Soil Science Society of America Journal, Madison, 48(2): 401-5, 1984.

KRUSE, F. A.; TIERY, M.; HAUFF, P. L. Spectral identification $(1,2-2,5 \mathrm{~nm})$ and characterization of Paris Basin kaolinite/smectite clays using a field spectrometer. In: INTERNATIONAL COLLOQUIUM - PHYSICAL MEASUREMENTS AND 
SIGNATURES IN REMOTE SENSING, 5., Courchevel, 1991. Proceedings. Courchevel, 1991. p.181-184.

LABSPHERE, REFLECTANCE CALIBRATION LABORATORY. Spectral reflectance target calibrated from $0.25-2.5 \mu \mathrm{m}$ reported in $0.050 \mu \mathrm{m}$ intervals. Sutton, 1996. 5p.

LINDBERG, J.D. \& SNYDER, D.G. Diffuse reflectance spectra of several clay minerals. American Mineralogist, Washington, 57: 485-93, 1972.

MADEIRA NETTO, J. S. Spectral reflectance properties of soils. Photo Interpretation, Paris, v.34, p.59-70, 1996.

MATHEWS, H. L.; CUNNINGHAM, R. L.; CIPRA, J. E.; WEST, T. R. Application of multispectral remote sensing to soil survey in Southeastem Pennsylvania. Soil Science Society of America Proceedings, v.37, n.1, p.88-93, 1973a.

MATHEWS, H.L.; CUNNINGHAM, R.L.; PETERSEN, G.W. Spectral reflectance of selected Pennsylvania soils. Soil Science Society of America Proceedings, Madison, 37: 421-4, $1973 b$.

MONTGOMERY, O.L. The effects of the physical and chemical properties of soil on the spectral reflectance of soils. West Lafayette, 1974, 110 p. (M.S. - Purdue University).

MYERS, V.I. \& ALLEN, W.A. Eletrooptical remote sensing methods as nondestructive testing and measuring techniques in agriculture. Applied Optics, Washington, 7(9): 1819-38, 1968.

NICODEMUS, F.E.; RICHMOND, J.C.; HSIA, J.J.; GINSBERG, I.W.; LIMPERIS, T. Geometrical considerations and nomenclature for reflectance. U.S. Departmente of Commerce, 1977. 52 p. (NBS Monograph 160).

OBUKHOV, A.I. \& ORLOV, O.S. Spectral reflectivity of Major Soil Groups and possibility of using diffuse reflections in soil investigations. Soviet Soil Science, Washington, 1: 174-84, 1964.

OLIVEIRA, J. B. Evolução dos trabalhos de levantamento de solos e dos estudos de variabilidade espacial no Estado de São Paulo. O Agronômico, v.40, n.2, p.138-148, 1988. 
OLIVEIRA, J. B.; MENCK, J.R.F.; BARBIERI, J.L. et al. Levantamento pedológico semidetalhado do Estado de São Paulo : quadrícula de Araras. Campinas : IAC, 1982. 180 p. (IAC. Boletim Técnico, 71).

PRADO, H. do. Os solos do Estado de São Paulo: mapas pedológicos. Piracicaba: Edição do autor, 1997. 205p.

ROSA, R. Introdução ao sensoriamento remoto. Uberlândia : Editora da Universidade Federal de Uberlândia, 1990. 136 p.

SABINS Jr., F. F. Remote sensing : principles and interpretations. San Francisco : W. H. Freeman, 1987. 449 p.

SANCHEZ, P. A . Suelos del trópico: características y manejo. San José, Costa Rica: IICA, 660 p., 1981

SHERMAN, D.M. \& WAITE, T.D. Eletronic spectra of $\mathrm{Fe}^{+3}$ oxides and oxide hydroxides in the near IR to near U.V. American Mineralogist, Washington, 70: 1262-9, 1985.

STEFFEN, C. (Ed.). CONVIRIS: Software para tratamento de dados espectrais obtidos em laboratório. São José dos Campos, 1997.

STONER, E. R.; BAUMGARDNER, M. F. Characteristics variations in reflectance of surface soils. Soil Science Society of America Journal, v.45, n.6, p.1161-1165, 1981.

STONER, E. R.; BAUMGARDNER, M. F.; WEISMILLER, R. A.; BIEHL, L. L.; ROBINSON, B. F. Extension of laboratory-measured soil spectra to field conditions. Soil Science Society of America Journal, v.44, p.572-574, 1980a.

STONER, E.R. \& BAUMGARDNER, M.F. Physicochemical, site, and bidirectional reflectance factor charcteristics of uniformly moist soils. West Lafayette, Purdue University, 1980. 94 p. (Technical Report, 111679).

VALERIANO, M. M.; EPIPHANIO, J. C. N.; FORMAGGIO, A. R.; OLIVEIRA, J. B. Bi-directional reflectance factor of 14 soil classes from Brazil. International Journal of Remote Sensing, v.16, n.1, p.113-128, 1995.

VANE, G.; GREEN, R. O.; CHRIEN, T. G.; ENMARK, H. T.; HANSEN, E. G.; POSTER, W. N. The Airbome Visible/Infrared Imaging Spectrometer (AVIRIS). Remote Sensing of Environment, v.44, p.127-143, 1993. 
VINK, A. P. A. Fotografias aereas y las ciencias del suelo. Paris : UNESCO. 1963. 200p.

VITORELLO, I.; GALVÃO, L. S. Spectral properties of geologic materials in the 400 to $2500 \mathrm{~nm}$ range: review for applications to mineral exploration and lithologic mapping. Photo Interpretation, v.34, n.2, p.77-99, 1996.

WHITE, J. G.; WELCH, R. M.; NORVELL, W. A. Soil zinc map of the USA using geostatistics and gfeographic information systems. Soil Science Society of American Journal., v. 61, p.185-194, 1997.

WHITE, K.; WALDEN, J.; DRAKE, N.; ECKARDT, F.; SETTLE, J. Mapping the iron oxide content of dune sands, Namib Sand Sea, Namibia, using Landsat Thematic Mapper Data. Remote Sensing of Environment, v.62, p.30-39, 1997. 